


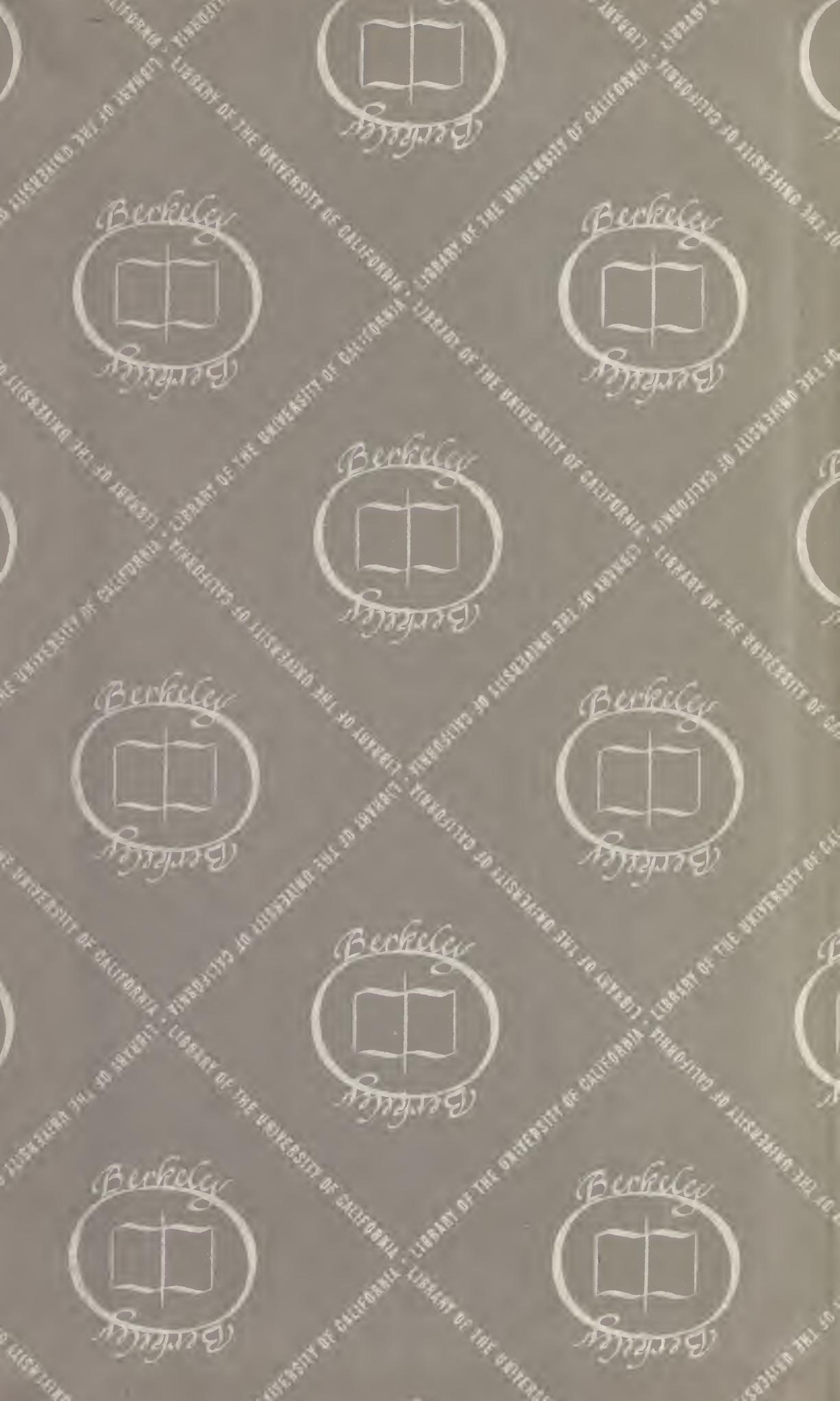




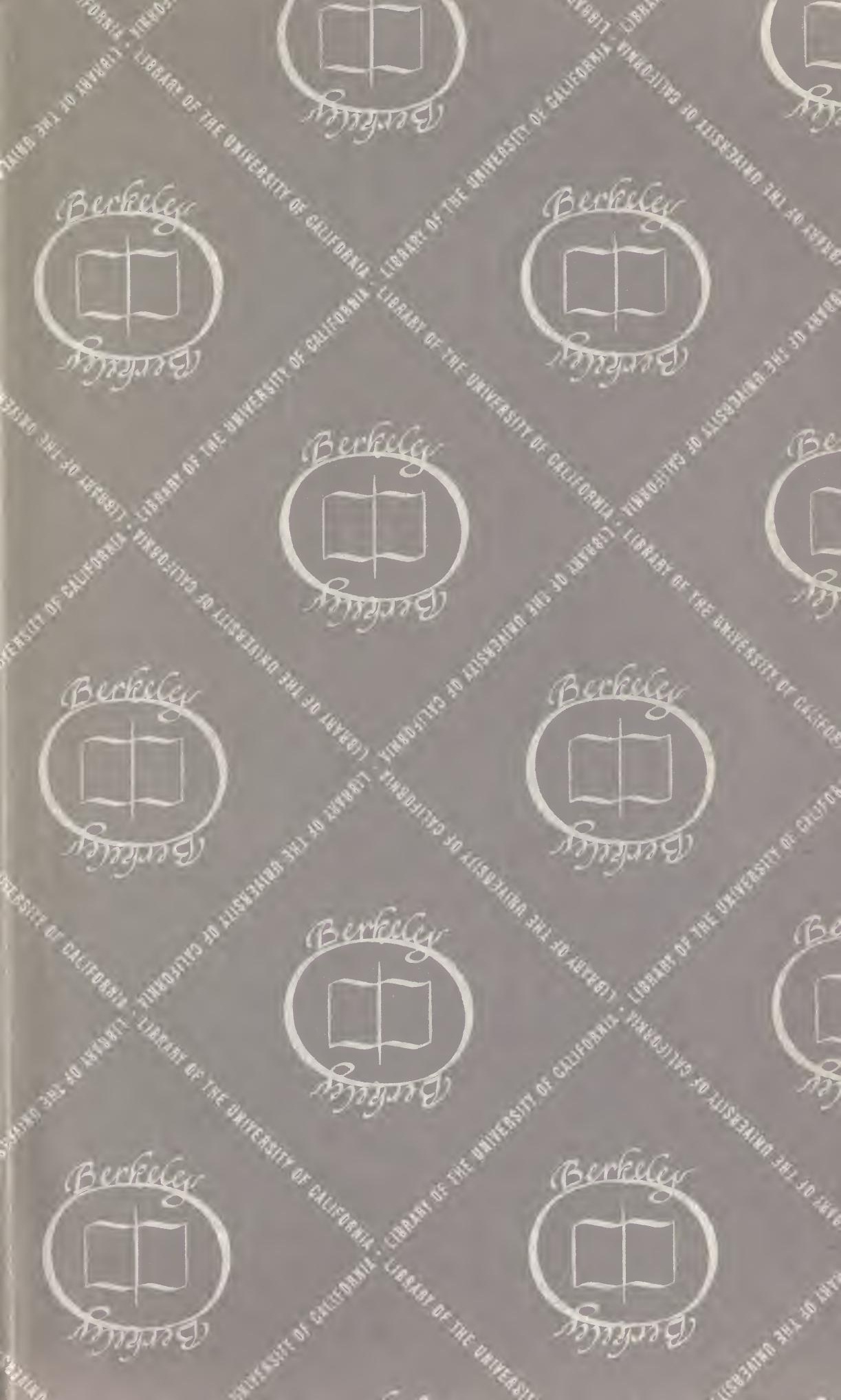







\title{
PERSONAL RECOLLECTIONS
}

\author{
$0 \mathrm{~F}$
}

\section{WERNER VON SIEMENS}


REESE LIBRARY

UNIVERSITY

CALIFORORIA. 


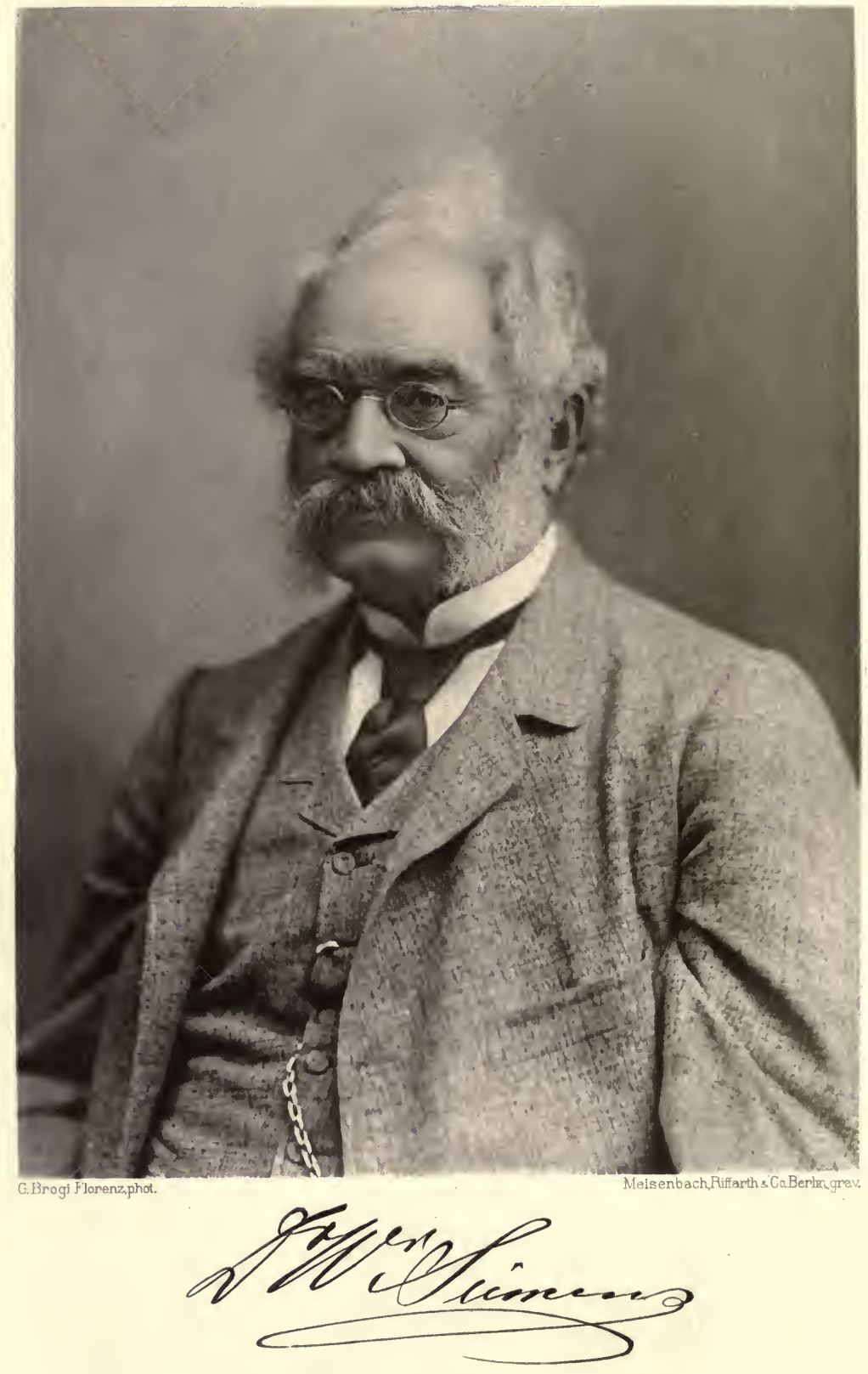

Verlag von Julius Spminger in Berlin N 


\title{
PERSONAL RECOLLECTIONS
}

\author{
OF \\ WERNER VON SIEMENS
}

TRANSLATED

BY

W. C. COUPLAND

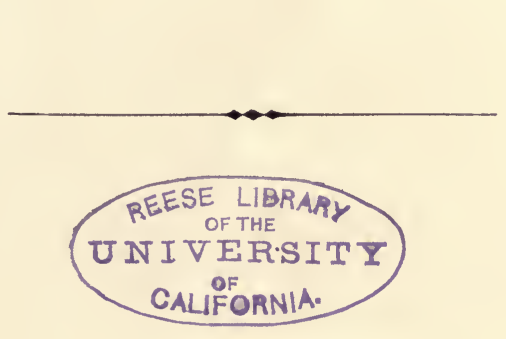

LONDON: ASHER \& CO

13 BEDFORD STREET, COVENT GARDEN 


\section{$T K 140$ \\ S 5 A 3213 1898}




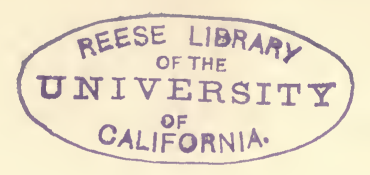

Harzburg, June 1889.

"The days of our years are threescore years and ten. or even by reason of strength fourscore years" - that is a serious monition to one who is approaching the mean point between these limits, and who has still much to do! We may indeed, speaking generally, console ourselves with the thought that others will do what we ourselves have not been able to accomplish, that the world accordingly will be no permanent loser; but there are certain tasks in regard to which this consolation is of no avail, since the performance of them can devolve upon no other. In this category falls the autobiographical narrative which I have promised my family and my friends.

I confess that the proposed undertaking has weighed heavily on my mind, being fully conscious of possessing the talent neither of the historian nor of the man of letters, and having had always a more lively interest in the present and the future than in the past. Further I have no good memory for names and dates, and also not a few events of my tolerably changeful existence are utterly beyond recall. On the other hand, however, I am desirous of being my own 
chronicler, in order to preclude the possibility of future misunderstanding and misinterpretation of $m y$ endeavours and actions, and I have an idea also, that it will be instructive and stimulating to the coming generation to be shown plainly how a young man, without inherited resources and influential supporters, nay even without proper preliminary culture, may solely through his own industry rise. and do something useful in the world. I shall not expend much thought on literary form, but shall jot down my recollections just as they occur to me, being only anxious that my statements may be clear and truthful, and my impressions and feelings faithfully reproduced. I shall, however, at the same time try to indicate those inner and outer forces which have borne me through weal and woe to the desired goals, and which have made my evening of life an easy and sunny one.

Here in my secluded villa at Harzburg I hope to find the needful calm for such a retrospect, for amid I the scenes of my active labours, in Berlin and Charlottenburg, I am too much claimed by the demands of the hour to be able without interruption to devote any considerable time to reflection on my own past. 


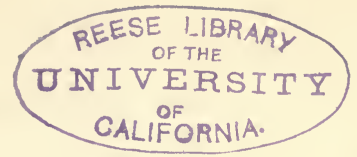

$\mathrm{M}_{\mathrm{y}}$ earliest recollection is of an act of juvenile heroism, which perhaps imprinted itself so indelibly on my mind on account of its striking effect on the development of my character. My parents lived till 1 my eighth year in Lenthe near Hanover, where I was born, and where my father farmed the estate (OberI gut) of a Herr von Lenthe. I must have been about five years of age when, playing one day in my father's room, sister Matilda, my senior by three year's, was led in weeping copiously. She was on her way to the parsonage for her knitting lesson, but a dangerous gander, she complained, kept barring her entrance into the parsonage yard, and had already repeatedly snapped at her. Accordingly she stontly refused, despite all her mother's coaxing, to repair to her lesson without a companion. My father, too, conld not succeed in shaking her determination. At last he gave me his stick, which was considerably bigger than myself, saying: "Then Werner" shall go with you, who I hope has more courage than you have." At first that appeared to me somewhat questionable, for my father dismissed me with the injunction: "If the gander comes, only go towards him bravely and hit him well with the stick, then he will run away!" And so it turned out. When 
we reached the yard-gate, the gander ran towards us with outstretched neck and terrible hissing. My sister turned tail shrieking, and I was strongly tempted to follow suit, but I trusted the paternal counsel and encountered the monster, with eyes shut indeed, but hitting out doughtily with the stick right and left. And lo, fear came upon the gander, and he returned cackling noisily to the flock of geese that had also betaken themselves to flight.

It is curious what a deep and lasting impression this first victory made on my childish mind. Even now, after well nigh 70 years, all the persons and surroundings, associated with this important event, stand clearly before my eyes. With it too is connected the only remembrance that remains to me of the appearance of my parents in their younger years; and numberless times in difficult situations of life the victory over the gander has unconsciously stimulated me, not to yield to threatening dangers, but to overcome, by boldly confronting, them.

My father came of a family settled since the Thirty Years War on the northern declivity of the Harz mountains, and engaged for the most part in agriculture and forestry. An old family legend, which it is true is rejected as unproven by recent historians, runs, that some venerable ancestor came in the Thirty Years War to North Germany with the troops of Tilly, was present at the storming of Magdeburg, then married a citizen's daughter whom he had snatched from the flames, and settled in the Harz region. As 
the existence of a reliable genealogical tree, somewhat I rare in middle-class families, proves, there has always prevailed a certain cohesion in the Siemens family. In recent times the gathering taking place every five years in some spot of the Harz, as well as an institution founded in 1876. have contributed to confirm this cohesion of a family now very widely distributed. As most of the Siemens my father was very proud of his family: and often told us children of members of it who had in some way or other distinguished themselves. Of these celebrities, save my grandfather with his fifteen children, my father being the youngest. I remember only a military councillor, who held a position of anthority in the council of the free town of Goslar at the time when the town lost its direct connection with the empire. My grandfather had rented the estate of the Baron of the Empire von 1 Grote. consisting of the manors Schanen and Wasserleben at the foot of the northern part of the Harz mountains. Wasserleben was my father's birthplace. Of the stories which my father loved to recount to us children, two have remained vivid in memory.

About 120 years ago the petty court (Duodezhof) of the Baron of the Empire von Grote was startled by the intimation that King Frederick II of Prussia was about to trespass on the imperial-baronial domain in his march from Halberstadt to Goslar. The old baron of the Empire awaited his powerful neighbour in befitting manner along with his only son, at the head of his customary contingent to the imperial 
army consisting of two men, and accompanied by his vassals - my grandfather and his sons, all on horseback.

As old Fritz with his mounted escort apploached the boundary, the imperial baron rode a few paces to meet him, and in due form bade him welcome "in his territory". The king, in whose memory perhaps the existence of this neighbouring realm had grown somewhat dim, appeared surprised at the greeting, returned however the compliment in proper form, and remarked turning to his retinue: "Messieurs, voilà deux souverains qui se rencontrent!" This caricature of old imperial glory has always remained in my memory, and very early kindled in us children the longing for i future national unity and greatness.

There was another event of even greater importance for the miniature state of Grote than the foregoing. My father had four sisters one of whom, Sabina, was very amiable and beautiful: excellencies which the young baron of the Empire was not slow to perceive, who accordingly offered her his heart and hand. It is unknown to me what attitude the old Freiherr assumed at this crisis; but from my grandfather the young gentleman met with a decided rebuff. The latter was unwilling that his daughter should enter a family where she would not be treated as an equal, holding tenaciously to the opinion of his time, that bliss and blessing can only spring fion a union of like and like. He forbade his daughter all further intercourse with the young nobleman, and resolved 
to facilitate the same by removing her firom the parental roof. But the young folk were manifestly possessed by the spirit of the new era, for on the morning of the arranged departure my grandfather received the dire intelligence, that the young baron harl carried off his daughter the previous night. Whereupon great excitement and hot pursuit of the flown birds by the grandfather and his five grown-up sons. The trail of the fugitives was followed to Blankenburg and there ended in the church. When entrance had been effected the young couple were found stationed at the altar, where the pastor had just pronounced the nuptial benediction!

How the family drama immediately thereafter developed itself it is no longer in my ability to say. Unhappily the young husband after a few blissful married years died without leaving any progeny. The barony of Schanen passed therefore to collateral relations, with the annexed burden it is true of the obligation to pay aunt Sabina for nearly half a century the statutory imperial-baronial widow's pension. When a - young artillery-officer I often visited the amiable and sprightly old lady at Kölleda in Thuringia, whither she had retired. "Aunt Grote" was still beautiful even in her old age, and formed at that time the acknowledged centre of our family. For us young people she possessed an almost irresistible charm, and it was a real treat to hear her speak of the persons and scenes of her to us dimly remote early life.

- My father was a clever. well-educated man. He 
had attended the grammar school at Ilfeld in the Har'z, and afterwards the University of Göttingen, in order to prepare himself thoroughly for his chosen vocation as * agriculturist. He belonged with heart and soul to that section of young Germany, which, growing up amid the storms of the great French Revolution, was - enthusiastic for freedom and a united Fatherland. Once in Cassel he had almost fallen into the clutches of Napoleon's myrmidons, when taking part in the weak attempts of certain visionary youths, who still strove to offer resistance after the prostration of Prussia. On his father's death he went to councillor Deichmann at Poggenhagen near Hanover, for the sake of practical training in agriculture. There he speedily fell in love with the councillor's eldest daughter, my - beloved mother Eleanor Deichmann, and married her his youth notwithstanding - he had hardly attained the age of 25 - after obtaining the farming of the Lenthe estate.

For twelve years my parents passed a happy life in Lenthe. Unfortunately however the political condition of Germany and especially of Hanover, then again under English rule, was very depressing to a man like my father. The English princes, who then kept court at the Hanoverian capital, troubled themselves but little about the welfare of the country. which they chiefly regarded as a hunting-ground. The game-laws were in consequence very strict, so that it was a common remark that in Hanover to kill a stag was more criminal than to kill a man! 
A charge of damaging game, through the use of unlawful means for protecting his property, was the cause of his leaving Hanover and seeking a new home in Mecklenburg.

The Lenthe estate (Obergut) is situated on a wooded ridge, the Benthe mountain, which joins on to the extended Deister range. The stags and wild boars, preserved for the royal chase and secure in their inviolability, visited in large herds the Lenthe fields with unmistakeable predilection. Although the entire village exerted itself to protect the crops by a nocturnal chain of guards, yet the game issuing forth in masses often in a few hour's annihilated hopes based on the work of a whole year. In a severe winter. when wood and field failed to afford the animals sufficient sustenance, they frequently foraged in complete herds in the villages themselves. One morning the bailiff announced to my father that a herd of deer had got within the farm-enclosure; the gate had been shut, and he wanted to know, what should be done with the animals. My father gave orders that they should be driven into a stable, and sent an express messenger to the Royal Supreme Court Hunting Bureau in Hanover with a notice of what had happened and the inquiry, whether it pleased that the deer should be sent to Hanover. That turned out however a most unlucky business for him! After a very short interval there appeared on the scene an imposing commission of investigation, which liberated the stags, and after a criminal inquiry of several days arrived 
at the conclusion. that violence had been offered to the creatures, inasmuch as they had been driven into the stall against their will! And my father had to think himself lucky that he got off with a heavy fine.

This is a picture in little of the then condition of the "Royal Hanoverian Province of Great Britain", as my dear countrymen were pleased to call their country with a certain pride. But even in the other German lands the state of things was not overmuch better, in spite of French Revolution and the glorious War of Liberation. It were well if the relatively fortunate youth of the present day now and again compared their own condition with the woes and often hopeless cares of their fathers, as a prophylactic against pessimistic ideas and fancies.

The freeer surroundings, which my father sought, he really found in the principality of Ratzeburg - appertaining to Mecklenburg-Strelitz, where he obtained a lease of the grand-ducal domain of Menzendorf for a long term of years. In this favoured little territory besides domains and peasant villages there was only a single nobleman's estate. The peasants it is true were still bound on the demesnes to services incident to socage tenure, but in the years immediately following our settling there these were abolished, and the possession of the peasant was freed from all burdens and even from almost all imposts.

Those were happy years of childhood which I and my brothers and sisters passed in Menzendorf, growing 
up with the village youth tolerably free and unrestrained. . The first years we older children - my sister Matilda, I and my younger brothers Hans and Ferdinand - roamed at large and unhindered through wood and wold. Our instruction was undertaken by my grandmother, who lived with us after her husband's death. She taught us reading and writing and exercised our memories by compelling us to learn by heart innumerable poems. Father and mother were too occupied with their economic cares, and the latter also with the rapidly increasing flock of my young brothers and sisters, to be able to concern themselves much with our education. My father was a thoroughly goodhearted but likewise hot-tempered man, who punished inexorably, if any of us did not do his duty, was untruthful or guilty of a dishonourable action. Fear of the father's wrath and affection for the mother, whose sorrow we never intentionally occasioned, kept our little band, otherwise somewhat unruly, in good order. The care of the elder for the fyounger children was prescribed as primary duty. In fact it reached so far that the seniors were punished with their juniors, if the latter ever rendered themselves liable to punishment. The said burden weighed especially upon me as the eldest, and awakened and confirmed in me at a very early age the feeling of obligation to care for my more youthful brothers and sisters. Accordingly I assumed the right to set the penal law in motion in respect of my juniors, which not unfrequently led to counter-coalitions and violent combats, which however were always fought 
out without invoking the parental intervention. I call to mind an incident of that time, which I will relate, as it is characteristic of our youthful life.

My brother Hans and I were wont to assail, and not in vain, crows and birds of prey with self-fabricated cross-bows, in the use of which we attained great precision. One day, a dispute arising in connection with the chase, I took the liberty of putting in practice the right of the stronger. My brother declared this to be base, and demanded that the dispute should be settled by a duel, in which my superior strength would give me no advantage. I found that equitable, and we proceeded to a cross-bow duel correct according to the rules, which we had learnt from occasional stories of my father of his student life. Ten paces were measured off", and at my word of command "Now" we both discharged our feathered arrows with knitting-needle for head at one another. Brother Hans had aimed well. His arrow hit the tip of my nose and penetrated under the skin to the root. Our joint outery brought the father on the scene, who pulled out the arrow and thereupon prepared for the chastisement of the delinquent by taking out his pipe-stem. This conflicted with my sense of right. I stepped with decision between father and brother" and said: "Father" it isn't Hans' fault, we have been fighting a duel." I see still the puzzled face of my father, who in justice could not punish what he had done himself and considered honourable. He quietly replaced the pipe-stem in the bowl adding only: "In future leave such nonsense alone." 
When my sister and I outgrew the tuition of grandmother Deichmann - née von Scheiter, as she. never forgot to sign herself - my father himself undertook our instruction for half a year. The outline of universal history and ethnography, which he dictated to us, was spirited and original, and formed the foundation of my later knowledge. When I had reached the age of eleven my sister was sent to a boardingschool at Ratzeburg, whilst I attended the grammarschool of the neighbouring market-town Schönberg from Menzendorf. In fine weather I had to do the something like three miles distance on foot. In wet weather the footways were impassable, and I rode to school on a pony. This, and my habit of always being a match for practical jokes, soon led to chronic war with the town-scholars, through whose midst I had generally to force a way, lance, i. e. bean-stick, in rest. This tourney, in which the farmer lads of my village sometimes assisted me, continued a whole year. It certainly contributed a good deal to call forth my active powers, yielded however only very indifferent scientific results.

A decided turning-point of my life occurred at Laster 1828, when my father engaged a private tutor. The choice was an exceedingly fortunate one. Sponholz, candidate of theology, was still a young man. He was highly cultured, but in bad odour with his spiritual superiors, his theology being too rationalistic, too little positive, as one would say now-a-days. Over us semisavage youths he contrived, even in the first weeks, 
to obtain a power mysterious to me to this day. He never punished us, hardly ever nttered a word of blame, shared however frequently in our games, and had the knack even through the medium of play of evoking our good qualities and repressing our bad ones. His teaching was in the highest degree stimulating and encouraging. He understood how to set up really attainable goals for our labours, and strengthened our energies and our ambition by his delight at the attainment of the proposed goal, which he himself frankly shared with us. Thus he succeeded in very few weeks in making out of unruly lazy boys the most eager and industrious scholars, whom he had not to urge to work, but rather to keep from attempting too much.

In me especially he awakened the inextinguishable feeling of delight in useful work and the ambitious desire actually to perform it. An important expedient employed by him for this purpose was his stories. If late in the evening our eyes began to close over our work, he would beckon us to him on the leather sofa where he used to sit beside our work-table, and whilst we clung to him paint us pictures of our own future. These either represented us at the heights of civil life, that we had scaled through industry and moral fitness, and which enabled us to lessen the cares of our parents - very considerable in that time of great difficulty for the agriculturist - or depicted our wretched fate, if we relaxed in our efforts, and were unable to resist temptation to evil. 
Unfortunately this happiest period of my boyhood did not last long, not even a full year. Sponholz had often attacks of deep melancholy, which probably in part arose from his mistaken theological calling and career, in part from causes which were unintelligible to us children. During one such attack he left the house on a dark winter's night, gun in hand, and after a prolonged search was found in a remote part of the estate with shattered skull. Our grief at the loss of the beloved friend and teacher was boundless. My own love and gratitude to him I have retained to the present day.

Sponholz's successor was an elderly gentleman, who had for years filled the office of private tutor in noblemen's families. He was in almost all respects the reverse of his predecessor. His educational system was of a wholly formal character. He required that before all things we should be docile and mannerly. Anything boisterous was especially his aversion. We had to be attentive and do our tasks at the prescribed times, accompany him with decorum in our walks, and not disturb him out of school hours. The poor man was sickly and after two years died of consumption in our house. A stimulating and moulding influence he certainly did not exert, and had it not been for the previous training of Sponholz, whose effect was enduring, the two years would have been pretty well thrown away, at least as far as I and my brother Hans were concerned. As for me the desire to do my duty and to learn thoroughly had, thanks to Sponholz, 
become so engrained, that so far from my ardour being damped I rather urged the tutor to my pace. In subsequent years the thought has often given me a pang, that I so often robbed the poor sick man of his needful rest by remaining after the close of lessons for hours together at my desk, quietly ignoring all the little devices he employed to be rid of me.

On the death of the second tutor my father determined to send brother Hans and myself to the Lübeck grammar-school, the so-called Catherine School, and carried out the plan after ny confirmation in the parish ehurch at Lübsee. As a result of the entrance examination I was put in the upper: and my brother in the lower fourth form. We were placed in no regular boarding house, but lodged with a Lübeck citizen, who at the same time boarded us. My father had such an unbounded faith in my trustworthiness that he also gave me the entire custody of my somewhat giddy brother, whose lawless nature had again come to the surface, as is evident from the nickname given him by the school "mad Hans".

St. Catherine's School, Lübeck, consisted of the grammar-school proper and the eity school, both under the same head-master and having similar classes as far as the fourth form of the grammar-school. The latter at that time enjoyed considerable scholastic repute. The instruction was mainly confined to the dead languages. The teaching in mathematics was 
extremely defective and did not satisfy me; in this subject I was put into a higher class, although up to that time I had only worked at Mathematics by myself, as neither of my tutors knew anything of it. The ancient languages on the other hand gave me a great deal of trouble, through lack of thorough grounding. Much as the study of the Classics interested and excited me, the acquisition of the grammatical rules, which offered no material for thought and positive knowledge, was distasteful to me. In the two following years I conscientiously worked myself up to the highest form, perceived however, that I should never find satisfaction in the study of ancient languages, and resolved to devote myself to architecture, • at that time the only technical branch. Accordingly in the fifth form I dropped the study of Greek, and took instead private lessons in Mathematics and landsurveying, in order to prepare myself for entrance into the Academy of Architecture at Berlin. On further inquiry, however, it unhappily appeared that the course at the Academy was too expensive, (at a time of everincreasing difficulty for the cultivators of the soil, when the selling price of wheat was a florin per bushel) to allow of my imposing so great a sacrifice upon my parents, having regard to the interests of my younger brothers and sisters.

$\angle$ In these straits I found relief in the advice of my preceptor in land-surveying, Freiherr von Bülzingslöwen, lieutenant in the Lübeck contingent, who had formerly served in the Prussian artillery. He advised 
- me to join the corps of Engineers, where I should have the opportunity of acquiring the same knowledge as a student of the Academy of Architecture. When I confided this plan to my father he at once consented, giving an additional important reason in its favour, the truth of which has been clearly demonstrated by recent German history. He said "The present condition of things in Germany cannot possibly last. A time will come when everything will be turned topsy turvy. The only fixed point in Germany is however the state of Frederick the Great and the Prussian Army, and in such times it is always better to be hammer than anvil." Accordingly at Easter 1834, in my seventeenth year, I quitted the grammar-school, and repaired with a very moderate supply of money - in my pocket to Berlin, in order to place myself among the hammers of the future.

When the painful leave-taking of the old home, of the intensely loved but overburdened and ailing mother, and the numerous brothers and sisters affectionately clinging to me, had been gone through: my father took me to Schwerin, and from there I entered on my pilgrimage. After I had crossed the Prussian frontier and found myself on a straight dusty road in the midst of a treeless and barren sandy plain, the feeling of a terrible loneliness overcame me. which was intensified by the melancholy contrast of the landscape with the old familiar scenery. Before my 
departure a deputation of the most respected peasants of the place had presented itself to my father with the petition not to send "so good a lad" to that faminestricken land Prussia: I should always find plenty to eat at home! The peasants would hardly credit my father, that beyond the desolate sandy borders lay also fertile land in Prussia. Despite my firm resolve to seek my advancement in the world through my own efforts, it did indeed for a moment seem as if the peasants were right and I was wending towards a sorry future. It was therefore a consolation when I met in my journeying a cheery and cultivated young man, who like me was tramping knapsack on back Berlinwards. He was no stranger there, and proposed that I should go with him to his inn, which he greatly praised.

It was the button-maker's inn in which I took up my quarters for the first night in Berlin. The host soon perceived that I did not belong to his regular patrons, and accorded me his good will. He protected me from the tricks of the young button-makers, and assisted me on the following day to discover the address of a distant relative, Lieutenant von Huet, in the Horse Artillery of the Guards. Cousin Huet received me kindly, was seized by a mortal terror however when he heard I had put up at the buttonmaker's inn. He at once gave orders to his servant to fetch my knapsack from the inn and to engage a room for me in a small hotel in the new Friedrichstrasse, offered also after the needful improvement of 
my toilet to proceed with me to General von Rauch, the chief of the corps of Engineers, and to inform him of my desire.

The general strongly dissuaded me, as so many cadets were already waiting their call to the artillery and engineering school, so that I could not hope to get in in less than four or five years. He advised me - to try the Artillery, whose cadets attended the same school as the engineers and had considerably better prospects. I accordingly made up my mind to try my luck in the artillery, and as there was no getting into the Guards, I obtained an introduction from lieutenant von Huet's father, colonel on the retired list, to Colonel von Scharnhorst, commander of the $3 \mathrm{rd}$ ArtilleryBrigade, and proceeded blithe of heart to Magdeburg. The colonel - a son of the celebrated organizer of the Prussian army - also indeed at first made sundry difficulties, remarking that the applications for cadetships were very numerous, and that of the fifteen young men, who had already offered themselves, he could only take the four who should pass the best examination. $\mathrm{He}$ finally however acceded to my request, and promised to admit me to the examination, provided his Majesty the King was pleased to allow me, although a foreigner, to enter the army of Prussia. My frank resolute bearing evidently took his fancy; but most influential perhaps was the circumstance, that he saw from my papers that my mother was a Deichmann of Poggenhagen, which adjoined his father's estate. 
As the entrance examination was not to take place till the end of October I had still three months for preparation. I therefore moved to Rhoden on the northern slope of the Harz, where a brother of my father owned some property, and there spent a few weeks in familiar intercourse with my relations, of whom the two pretty and amiable grown-up daughters in particular made a great impression upon me: I willingly allowed them to exercise their refining influence on the young and still somewhat umpolished cousin. Then I went with my cousin Louis Siemens, my junior by a few years, to Halberstadt, where I prepared myself in good earnest for the entrance examination.

The programme of the examination placed in my hands by Colonel von Scharnhorst caused me however a good deal of uneasiness. In addition to Mathematics, History Geography and French were especially required, and these subjects had been taught at the Lübeck grammar-school only in a very superficial manner. I could scarcely hope to make good my deficiences in a couple of months. There was still wanting my discharge from the Mecklenburg military service, which my father would have to purchase, and the permission of the King to enter the Prussian army. I marched, therefore, towards the middle of October with a heavy heart to Magdeburg; where I was disappointed in not finding the expected letter from home along with the necessary papers. When nevertheless I was just about to start for the examination at the prescribed hour, to my 
great and joyful surprise I was met by my father, who had himself driven over to Magdeburg in a light conveyance, in order to deliver into my hands the papers by the right time, as the post in those days was far from expeditious.

The examination took a favourable course for me from the commencement, and beyond my expectation. In Mathematics I was decidedly ahead of my fourteen competitors. In History I had luck, and got off tolerably well. In modern languages I was certainly weaker than the others, but my better knowledge of the ancient languages made up for it. The outlook was worse in Geography; I soon perceived that most of them knew more of the subject than I did. But here I was favoured by a particularly lucky coincidence. The examiner was a certain Captain Meinicke, who had the reputation of being a very learned and at the same time original man. He passed for a great connoisseur of 'Tokay wine, as I afterwards learnt, and that was perhaps the reason of his curiosity regarding the situation of Tokay. No one knew, whereupon he waxed very wrath. When my turn came last of all by good hap it occurred to me, that Tokay wine had once been prescribed to my invalid mother, and that it had also borne the name of Hungarian wine. At my answer "In Hungary, Captain!" his face brightened up, and with the exclamation "But, gentlemen, you must surely know Tokay wine!" he gave me the highest mark in Geography.

So I was one of the fortunate four who had passed 
the best examination, but still had to wait four anxious weeks for the royal permission to enter the army, and when at the end of November it arrived, I could not immediately be admitted, because I had only been born on the 13 th of December 1816, and so had not yet passed my seventeenth year. I, however, was allowed a special drill-sergeant, who strenuously drilled me in civilian dress in the Cathedral square.

My performance soon gained the approval of the severe bombardier, although there was one point which almost drove him to despair. I had extremely curly light-brown hair, that absolutely refused to conform to the military regulations, which required that the hair should lie evenly on the temples. On inspection-day the captain had expressed displeasure at the disorderly hair of the recruit, and in consequence, all conceivable experiments were instituted to conceal in a measure this military blemish. The sediment of a favourite Magdeburg beer seemed to be most effective. I was obliged to order many a bottle for the purpose, as unfortunately only the sediment could be of any use to me. After repeated applications I succeeded in rendering my hair tolerably smooth, but after an interval it showed symptoms of revolt, and usually on parade to the horror of the bombardier certain rebellious locks persisted in protruding from the even layer.

Despite the great exertions exacted, and the rough and apparently harsh treatment at the hand of the drillsergeant, I still look back with pleasure to my time 
when a recruit. The roughness is sheer habit and does not spring from intention to inflict pain. It therefore does not go very deep, on the contrary has something refreshing and stimulating about it, especially if combined with humour, as has almost always been the case with the models of military harshness known to fame. The service over the incivility is forgotten, and the feeling of comradeship is again uppermost. The feeling of comradeship, which pervades the entire Prussian Army from king to recruit, renders the strict discipline, the toils and hardships reaching often to the extreme limit of the capacity to undergo them, endurable, and constitutes its cementing bond in woe and weal. It will, accordingly, be often very hard for the military veteran to feel comfortable in civil life: he misses therein the reckless rudeness on a substructure of good fellowship.

After six months drill came the great event of advancement to the post of bombardier. It was an elevating feeling to be now the superior of hundreds and thousands and to be duly saluted by every private. Then followed the order to the horse artillery, then the interesting artillery practice, in which for the first time I became aware of my technical abilities, since what most found hard to comprehend appeared to me matter of course. Lastly, in the autumn of 1835 , I received the longed-for order to attend the school - of the united artillery and engineer's in Berlin, and therewith the fulfilment of my ardent desire to have an opportunity to learn something useful. 
The three years, which from the autumn of 1835 to the summer of $1838 \mathrm{I}$ spent at the Berlin Artillery and Engineering School. I reckon to the happiest of my life. The sociable life with young people of the same age and with the same aims, the common study under the guidance of able teachers, of whom I will only name the mathematician $\mathrm{Ohm}$, the physicist Magnus, and the chemist Erdmann, whose instruction opened to me a world new and full of interest, made this time one of extraordinary enjoyment. In addition to that, I found in one of the comrades of my brigade, William Meyer, a real friend, with whom till his death I was united by the bond of the closest and completest friendship. I had before at the Lübeck grammar-school entered on the first stage of such an intimate friendly alliance, and imagined I had found in a fellow pupil a genuine friend, but on calling upon him one day he gave orders to say he was not at home, although I was perfectly sure that he was in the house and concealing himself from me. That appeared to me such an unpardonable breach of proper friendship, that I severed the tie with intense pain, and could never again bring myself to treat him as a friend.

William Meyer I got to know when the horseartillery was stationed at Burg, whither he had been ordered before me. He had a far from imposing figure, was in no respect distinguished or talented, possessed however a clear understanding, and pleased me from the first by his straightforward unaffected 
nature, and his unimpeachable sincerity and trustworthiness. We chummed together at the School, lived and studied together, had the same quarters then and thenceforward, whenever circumstances allowed of it. Our notorious friendship and the circumstance that I revolted against the "tyranny of the ensigns", which led to a duel with the senior of my room, in which Meyer acted as my second, had the curious result, that in almost all the duels which occurred in the first year at the School, Meyer and I were chosen as seconds of the opposing parties.

These duels were only in a few instances followed by dangerous consequences, had however so far a very useful effect as they tended to preserve a polite tone in social intercourse.

Our year was the first in which the cadets were admitted in limited numbers after a pretty stiff entrance examination, and were then ordered to the School on the completion of their year of service. Before that no difference was made between the candidates for commissions and others, and it was then often only after the lapse of several years of service, which in part had to be spent in barracks, that the ablest or perhaps the best-recommended were ordered to the School. The somewhat unpolished tone, which had clung to the young fellows through prolonged intercourse with unrefined comrades, was most effectively and quickly corrected by means of the duels.

My three years at the military school passed without any important events. Although I suffered much 
from attacks of intermittent fever, and once also was obliged to lie several months in hospital on account of injury to the shin, yet I contrived to pass successfully the three examinations - the ensign, the army-officer and finally the artillery-officer examination, although without special distinction. I had with inflexible industry crammed the required matter into my head in order afterwards to forget it as quickly again, but had devoted all my spare time to my favourite sciences, Mathematics, Physies and Chemistry. The fondness for these sciences has remained all through my life, and has been at the bottom of my after successes.

Great was the joy when the school course completed, I received a four weeks furlough to visit my home along with my friend Meyer. My brothers and sister's, whose number had risen to ten, and even my parents hardly recognized me.

The whole village rejoiced with them on the return of the "Muschü", the traditional title of the sons of "the Manor". 'There were really tonching meetings with the worthy people of our own and the neighbouring villages, who for the rest had great respect for the Prussian officers, in whom certainly they perceived no signs of Prussia s starving condition.

My elder sister Matilda was just celebrating her wedding with Professor Karl Himly from Göttingen, who remained a dear friend of mine until his death. Hans and Ferdinand had become farmers. My third younger brother, William, was at the school at Lübeck and was destined for commerce. The next two, Frederick 
and Charles, likewise attended the Lübeck School, where they boarded with a younger brother of my mother, Ferdinand Deichmann, merchant.

That William wiv to be a business-man didn't at all please me. At that time I shared the aversion of Prussian officers to the mercantile class, and also William's somewhat reserved but intelligent nature and his clear understanding particularly attracted me. I accordingly begged my parents to let him accompany me to my future garrison-town Magdeburg, that he might attend the highly esteemed school of 'Trade and Commerce of that place. The parents consented, and so we took him with us to Magdeburg, where I installed him in a small boarding-house, having myself according to the regulations to reside the first year in barracks. At the expiration of this year, which I had to devote entirely to the strict military service, friend Meyer and I took up our quarters in the town, and I brought William, now sixteen years of age, to reside with me. I had a parternal delight in watching his rapid development, and helped him with his school tasks in my leisure hours. I also induced him to give up the unsatisfactory lessons in Mathematics at the school and to learn English instead. This turned out very important for his future career. I myself gave him mathematical instruction every morning from 5 to 7 , and was rewarded by the particularly good examination he afterwards passed in that subject. 'To myself this tuition was of great utility, and it also made it easier for me to resist the temptations of an officer's 
life, as well as stimulated me energetically to continue my scientific studies.

Unhappily this fraternal intercourse was much troubled by the increasingly ominous communications of my father regarding the health of our beloved mother. On the 8 th of July 1839 she succumbed to her malady, leaving my father, himself ailing, weighed down with sorrow and serious material cares, together with the numerous children still to be educated, in a very doleful condition. I forego the description of the poignant grief on the mother's loss. 'The love for her' was the strong tie that held the family together, and the fear of distressing her always formed for us children the most effective guarantee for our good behaviour.

I received a brief furlough to visit our home and my mother's grave. Unhappily the enfeebled health of my father inspired me with but little confidence in the duration of a regular family life, favourable to the prosperity and development of the younger members. The correctness of my foreboding was only too soon confirmed. In barely half a year, on the 16 th January 1840, we also lost our father.

On the death of the parents, guardians were appointed by the court of ward for the younger children, and the management of the domain of Menzendorf was entrusted to my brothers Hans and Ferdinand. My youngest sister Sophia was adopted by Uncle Deichmann in Lübeck, whilst the youngest brothers Walter and Otto remained for the present under the grandmother's care in Menzendorf. - 
The scientific-technical studies, to which I now devoted myself with increased ardour, nearly had very serious consequences in the following summer. I had heard that my cousin, the Hanoverian artillery officer A. Siemens, had made some successful experiments with friction fuses, which were intended to be used for the firing of canon in place of the hand fuses then exclusively employed. The importance of this discovery was evident to me, and I resolved myself to make experiments in this direction. As the inflammatory materials employed did not act with sufficient certainty, in the absence of better implements I stirred up together an aqueous solution of phosphorus and chlorate of potash in a pomatum bowl with very thick bottom, and placed the bowl, as I had to go to the drill ground, carefully covered, in a cool window corner.

When I returned and looked with some anxiety for my dangerous preparation I found it to my satisfaction still in the same corner. But on carefully taking it up and barely touching the match standing in the paste, which had served to stir up the mixture, a violent explosion took place, which hurled the shako from my head and shattered all the window-panes together with their frames. The entire upper part of the porcelain bowl was scattered about the room in the form of fine powder, whilst its stout bottom was werlged firmly into the window sill.

The cause of this altogether unexpected explosion turned out to be this: that my man on cleaning the room had placed the vessel in the oven, and let it 
dry there a few hours before putting it back in its place. Strange to say I was not visibly wounded, only the violent pressure of the air had so contused the skin of my left hand, that the forefinger and thumb were covered by a large haematocystis. Unfortunately, however, the drum of my right ear was fractured, which I immediately perceived from the circumstance that I was able to blow ont the air through both ears: the drum of the left ear had been burst the year before during artillery practice. I was in consequence for the moment quite deaf and had heard no sound, when suddenly the door of my room opened and I saw the whole anteroom full of horror-stricken people. The report had immediately spread that one of the two officers resident in the lodgings had shot himself.

In consequence of this mishap I have long suffered of difficulty of hearing and still suffer from time to time, whenever the closed rents in the tympana chance to open.

In the autumn of 1840 I was transferred to Wittenberg, where I had to enjoy for a year the dubious pleasures of life in a small garrison-town. All the more eagerly did I continue my scientific studies. In that year Jacobi's discovery was made known in Germany of precipitating copper in a metallic form by means of the galvanic current from a solution of the sulphate. This process interested me in a high degree, as it evidently was the key to a whole class of hitherto unknown phenomena. As I succeeded well with the 
copper precipitates I tried also to precipitate other metals in the same way, but only with moderate success owing to my limited means and apparatus.

My studies were interrupted by an event, which in its consequences had an important influence on my future career. The frequent squabbles in the smaller garrison towns between the members of different branches of the service had led to a duel between an infantry officer and an artillery officer with whom I was on friendly terms. I had to act as the latter's second. Although the duel terminated with only an insignificant wound sustained by the infantry officer, it came for certain reasons to be taken notice of and to be dealt with by a court-martial. The statutory punishments for duelling in Prussia were at that time Draconian in their severity, but precisely on that account were almost always mitigated by an early pardon. In fact by the court-martial held in Magdeburg the principals were condemned to ten and the seconds to five years imprisonment in the fortress.

I was condemned to confinement in the citadel of Magdeburg and had to report myself there on the confirmation of the sentence. The prospect of being shut up for at least half a year without occupation was not pleasant, but I consoled myself with the thought that I should have a good deal of leisure time for my studies. In order to make good use of this time I searched out a chemist's shop on my way to the citadel, and provided myself with the necessary means for pursuing my experiments in electrolysis. A friendly 
young fellow in the business promised not only to smuggle these articles into the citadel, but also to execute promptly future orders. and conscientiously kept his promise.

Accordingly I set up a small laboratory in my barred but roomy cell and was quite contented with my situation. Fortune favoured me in my work. I remembered that some time ago I had tried experiments with my brother-in-law Himly in Göttingen for the production of pictures according to the process made known a little while before by Daguerre, and that hyposulphite of soda employed in these experiments had dissolved otherwise insoluble salts of gold and silver. I determined therefore to proceed on these lines, and to test the applicability of such solutions for electrolysis. To my unspeakable joy the experiments succeeded in a surprising manner. I believe it was one of the happiest moments of my life when a German silver tea-spoon, which I had dipped into a beaker filled with a solution of hyposulphite of gold and connected with the zinc pole of a Daniell battery, whilst the copper pole was connected with a louis dor as anode, changed in a few minutes into a golden spoon of the finest and purest lustre.

Galvanic gilding and plating was then, at least in Germany, still quite new and naturally caused a sensation in the circle of my comrades and acquaintances. I almost immediately concluded a bargain with a Magdeburg jeweller, who had heard of the marvel and visited me in the citadel, whereby I sold him the right 
of making use of my process for forty louis dor, which supplied me with the required means for making further experiments.

In the meantime a month of my confinement had elapsed, and I imagined I should have at least a few more months quietly to continue my work. I improved my apparatus and lodged a petition for a patent, whereupon with surprising rapidity a Prussian patent for five years was granted me. But the officer of the guard unexpectedly appeared and to my great terror, I must confess, handed me a royal order-incouncil announcing my pardon. It was really hard to be so suddenly torn from my successful activity. According to the regulations I was obliged to leave the citadel the same day, and had neither an abode into which I could put my effects and apparatus, nor any idea whither I should be ordered.

I therefore drew up a petition to the commander of the fortress, in which I begeed to be allowed to occupy my cell for a few more days, in order that I might arrange my affairs and finish my experiments. I came off badly by that however! 'Towards midnight I was awakened by the entrance of the officer of the guard. who conmunicated to me that he had receiver orders to turn me at once out of the citadel. The commander had regarded it as a sign of ingratitude for the royal favour extended to me. that I desired a prolongation of my imprisonment. Accordingly about midnight I was conducted out of the citadel with my effects and had to get a lodging in the town. 
Luckily I was not again sent to Wittenberg; but received an order to go to the pyrotechnic factory at Spandau. My discovery had in the eyes of my superiors doubtless made me appear less qualified for active service! The firework factory was a relic of the old times when "gunnery" (Constablerthum) was still an art, of which the manufacture of fireworks was held to be the crown. My interest in the activity assigned to me was great; in good spirits I repaired to Spandau and took possession of the rooms in the citadel allotted to the pyrotechnic manufacture.

My new occupation was in fact very interesting, and I devoted myself to it with the greater eagerness as a large order had arrived at the pyrotechnic department for a quantity of fireworks, which it was intended to let off on the birthday of the Russian Empress in the park of Prince Charles at Glienicke near Potsdam. Owing to the progress of chemistry means were afforded at that time for the production of very beautiful coloured flames unknown to the old gunners. My fireworks on the Havel lake at Glienicke brought me therefore much honour and recognition especially by the splendour of their colours. I was asked to the princes table, and received an invitation to engage the young Prince Frederick Charles in a sailing-match, as the sailing boat in which I had come from Spandau to Glienicke had distinguished itself by its excellent speed. I had the honour of conquering the future victor of famous battles, who even then impressed me in a high degree by his 
resolute energetic character or his "smartness". as one now expresses it.

With the letting off of these fireworks my command of the pyrotechnic factory came to an end. and - to my delight I was ordered to Berlin for service in the ordnance department. Through this transference my greatest wish was fulfilled, to obtain time and opportunity for further scientific studies and for increasing my technical knowledge.

But there were also other reasons which made this change welcome to me. After my parents death the duty devolved upon me of providing for my younger brothers and sisters, of whom my youngest brother Otto was at our mother's death only in his third year. The farming of the domains still remained it is true for a term of years in the hands of the family, but the times continued to be extremely bad for agriculture, so that the slight profits, which were made by my brothers Hans and Ferdinand by farming; did not suffice for the education of the children. I was therefore obliged to look out for some way of earning money in order to fulfil my obligations as senior of the family, and that appeared to me to be easier in Berlin than elsewhere.

My brother William had meanwhile completed his course at the Magdeburg School, and at my suggestion had gone for a year to Göttingen, to sister Matilda, in order to prosecute his scientific studies. After that he entered as pupil the Count Stolberg engineering works in Magdeburg. He there devoted 
himself with great energy to practical engineering, which just then was undergoing rapid development in Germany in consequence of the introduction of railways.

I kept up a frequent correspondence with William, and got him to communicate to me the problems which exercised his constructive faculty. One such problem was the precise regulation of steam engines, which were assisted by wind or water mills. William's plan did not satisfy me, and I proposed to employ as regulative principle a heavy freely swinging circular pendulum, which, comnected with the engine to be regulated by a differential mechanism, might effect an absolutely uniform rotation. instead of diminishing the irregularities by the only means then known, the very imperfect regulator of Watt. To this suggestion was due the construction of the differential governor, . to which I shall return in the sequel.

In Berlin my efforts to earn money by my inventions were soon attended with success. although I was very much hampered by being as military officer considerably restricted in the choice of devices for initiating business undertakings. I succeeded in concluding an agreement with the German-silver manufacturer J. Henniger, by which I agreed to set up an establishment for him for gilding and plating in accordance with my patent in return for a share in the profits. Thus arose the first establishment of the kind in Germany. In England a Mr. Elkington had already started a similar establishment, employing 
another process, now in general use - viz. depositing from gold and silver cyanides - which soon obtained great success.

In the negociations with regard to the Berlin plan and the fitting up of the establishment I was materially assisted by my brother William, who had paid me a holiday visit, and who succeeded at the same time in inducing a Berlin engineering firm to adopt the differential governor. As he clearly showed talent for such negociations and himself wanted to get to know England, we agreed that he should try to utilize my inventions in that country and for this purpose obtain a longer leave of absence from his factory. Considerable means I conild certainly not afford him for his journey, and I have often wondered how in spite of this he attained his end. With excellent judgment he went straight to our competitor Elkington, who at first cut him short with the remark that we had no right to use our process in England, as his patent gave him the exclusive right to employ electric currents, produced by electric batteries $\mathrm{or}^{\circ}$ by induction, for depositing gold and silver. William had sufficient presence of mind to reply that we employed thermo-electric currents, therefore did not infringe his patent. I did in fact at once snceed in making a thermo-electric battery, consisting of pairs of bars of iron and German silver, with which we could very well precipitate gold and silver from hyposulphite solutions. As a consequence Willian succeeded in selling our English patent to Elkington for $£ 1500$. 
This in our then circumstances was a colossal sum, which put for some time an end to our financial difficulties.

On his return from England William re-entered his Magdeburg factory, but soon found he had lost his relish for such small undertakings, after becoming acquainted with the large scale of English industrial operations and acquiring a taste for English life. He accordingly proposed to settle in England, and as I approved of the project, we took out a patent there for the jointly elaborated differential-governor, in order to facilitate its introduction into England.

I had meanwhile made two more discoveries which William was likewise to try to turn to account there. The prosecution of my experiments in electrolysis had led me to attempt to get also good deposits of nickel from a solution of the double salt of sulphate of nickel and sulphate of ammonia. This nickelizing appeared of especial importance for engraved copperplate which, provided with a coating of nickel, allowed of a far larger number of impressions, without the fineness of the engraving being blunted by the nickelizing. To derive benefit from this process I had made a compact with a Berlin house, from which I expected considerable profit. Unluckily, however, soon afterwards the galvanic depositing of iron from the corresponding iron solution was discovered, which had the great advantage over the nickel coating, that it could be easily renewed, when worn out, in that the iron could be again liberated by dilute sulphuric 
acid and the plate then coated afresh with iron. This made my nickelizing worthless for this purpose. A few years later it was again discovered and made known by Professor Böttger, but has only in recent times been much employed in industrial operations.

The second discovery consisted in the application - of the zinc printing to a rotating fly-press, which process had just then come to be known. With the help of a skilful mechanician. the watch-maker Leonhardt, I had prepared a model of such a press, which very satisfactorily executed the necessary operations for producing lithographic impressions from a cylindrical zinc plate. But it subsequently turned out on its employment on the large scale by William in England that zinc printing allowed of no rapid repetition of impressions. After from 150 to 200 impressions the work had to be interrupted for a pretty long time, or else an obliteration of the reprint on the eylinder took place.

When my brother in England met with these difficulties I obtained a six week's furlough and visited him in London, where he had rented a small place for our experiments in a narrow lane of the City near the Mansion House. Despite the most strenuous efforts we could not however succeed in overcoming the difficulties. We succeeded indeed in obtaining re-impressions from even century old prints by a regenerating process - by continuous heating, if I remember rightly, in a solution of salts of barium - and our process, to which we had given the grand name "anastatic printing", accordingly excited in England much attention 
and contributed to making William known there; but it soon became clear to us that speculative inventions are a very uncertain affair and only in very rare cases lead to good results. unless supported by thorough knowledge and ample means.

To me personally the journey to England proved very stimulating: and at the same time gave a more earnest and critical direction to my further endeavours, leading me to look rather at the solidity of my foundations than at the hoped for result. This was still more confirmed by my return journey through Paris, where in the then flourishing time of the rule of Louis Philippe the first great French Industrial Exhibition was taking place.

Unfortunately my stay in Paris was disturbed by an unpleasant incident. I had intended to decide in Brussels whether I should return by way of Paris or by direct route, had arranged therefore with William that he should send to Paris the money requisite for the strengthening of my travelling budget, if I should write him to that effect from Brussels. When I decided therefore to take the journey to Paris. I sent with the request for money my Paris address and entrusted the letter to the landlord of 1 my hotel.

Arriving in Paris, perched on the top of an omnibus of the messageries générales after a two days journey, I found the eity in consequence of the Exhibition filled to overflowing: and succeeded only with difficulty in obtaining a small garret room on the eighth floor of the hotel des messageries générales, in 
which it was only possible to stand upright if the window which served also for roof were placed horizontally. As my cash had in consequence of the extra travelling been reduced to a minimum I could not think of a change of residence until the expected remittance had arrived. Almost a fortnight passed however. A young Berliner who had come to Paris for the Exhibition found himself in the same plight. We had very thoroughly to study the art of living in Paris without money; and being entirely without aequaintances or other sources of assistance found ourselves at last in a very uncomfortable position. Finally we simultaneously resolved to employ our remaining resources in despatching letters to London and Berlin, as at that time only prepaid letters were accepted. At the post-office it turned out, however. that my ready money was not quite sufficient for the purpose. The young Berliner - Schwarzlose was his name - magnanimously came to my assistance, but was then obliged to forego the dispatch of his own missive. his funds being now exhausted.

'This magnanimity found its reward, for on the same evening the longed-for money-letter from my brother arrived, instead of after the lapse of a week. as I had feared. The postage of the Brussels letter had been embezzled by the boots of the hotel. the Post-Office authorities had therefore not despatched the letter, had however written to the addressee that if he desired to have it he must remit the postage. Only after my brother had done this, and had received 
the letter containing my address, could he let me have the truly "needful".

Our distress was accordingly relieved, but the Parisian trip was rendered vain, for my furlough was now at an end. As a compensation I got practically to know what want of money really means. Of Paris itself I saw little but the streets in which I tramped away my hunger.

Returned to Berlin I very seriously reflected on the aims I had lately been pursuing, and saw clearly that the chase of discoveries, by which I had allowed myself to be carried away through the facility of a first success, would if continued probably be my own and my brother's ruin. I accordingly got rid of all my inventions; sold even my share in the manufactory set up in Berlin, and devoted myself again with heart and soul to serious scientific study. I attended courses at the Berlin University, soon however perceived to my dismay from the lectures of the celebrated mathematician Jacobi, that my previous training was insufficient to enable me to follow him to the end. This imperfect schooling in scientific study has always to my great regret kept me back and crippled my efforts. All the more grateful am I to some of my earlier teachers, among whom I must specially mention the physicists Magnus, Dove and Riess, for friendly reception into their highly interesting circles. I also owe many thanks to the younger Berlin physicists, who allowed me to take part in founding the Physical Society. That was a wonderfully stimulating 
association of talented young scientists, who subsequently almost without exception became celebrated by their achierments. I need mention only the names of du Bois-Reymond. Brücke. Helmholtz, Clausius, Wiedemann, Iudwig, Beetz and Knoblauch. Intercourse and cooperation with these young men, distinguished by talent and earnest endeavour. strengthened my preference for scientific study and labours. and kindled in me the determination to be in future the votary of strict science alone.

But circumstances were stronger than my will, and the native impulse never to let acquired knowledge lie idle, but as far as possible to make some use of it, led me ever and again back to technology. And so it has been my life long. My affection has always been given to pure science as such, but my labours and achievments have been for the most part in the domain of applied science.

This technical turn was especially favoured and supported by the Polytechnic Society, to which as a young officer I zealously devoted myself. I took an active part in its proceedings: and in the answering of the questions which were deposited in the querybox. 'The answering and discussing of these soon formed a part of my regular activity and proved a good school for me. My scientific study stood me in good stead, and it became clear to me, that technical progress is only to be attained by the diffusion of scientific knowledge among technologists.

At that time there still existed an unbridged 
gulf between pure and applied science. The meritorious Beuth, who is unquestionably to be regarded as the founder of the technical science of North Germany, had indeed in the Berlin Industrial Institute erected an institution, which was especially designed for the diffusion of scientific knowledge among young technologists. The existence of this institute, out of which arose the Industrial Academy and finally the Technical College in Charlottenburg, was however too short for raising the level of education of the eraftsmen of the period.

Prussia was at that time still a purely military and bureaucratic state. In its official class alone was culture to be found, and it is doubtless mainly owing to this circumstance that even at the present day the semblance of an official title is regarded and striven for as an external mark of a cultured and respected man. Of the industrial body only agricul- or turists, from whom the military class as well as the bureaucracy was almost without exception recruited, had a respectable status in the eyes of the latter. In this country, wasted and impoverished by a century of wars, there existed no longer a well-to-do bourgeoisie to * counterpoise in culture and property the military and official class. It must however be added, that this state of things was in part attributable to the fact, that the representatives of science always highly respected in. Prussia under the rule of the far-seeing Hohenzollern did not consider it compatible with their dignity to manifest a personal interest in technical progress. The 
same may be said in respect of plastic art, whose representatives regarded - and in part, I believe, still regard - it beneath their dignity to employ a part of their creative power for the elevation of industrial art. Through my activity in the Polytechnic Society I arrived at the conviction that scientific knowledge and scientific methods of investigation are capable of developing technology to a degree far beyond anything that can be foreseen. It further had the advantage of making me personally acquainted with - Berlin manufacturers, and of affording me personally an insight into the achievments and defects of the industry of the time. My advice was often sought by manufacturers, and I thereby became acquainted with the contrivances employed and the modes of working. It became clear to me that the industrial arts cannot advance by sudden leaps, as has often been possible to science through the fruitful ideas of a few remarkable men. A technical invention only obtains value and importance if technology itself has so far progressed, that the invention is a practical one and supplies a need. Hence one so often sees the most considerable inventions unutilized for decennia, until all at once their great importance is recognised, their hour having arrived.

Of the scientific-technical questions which at that time especially occupied me, and at the same time gave occasion to my first literary labours, the first owed its origin to a communication in a letter of my brother William with respect to an interesting 
engine, which he had seen at work in Dundee. From a rather brief account it appeared that this engine was not driven by steam but by heated air. This idea interested me exceedingly, since it appeared to afford a foundation for an advantageous transformation of the whole engine-constructing art. In a paper entitled "On the use of heated air" as mechanical power $“$, contributed in 1845 to Dingler"s Polytechnic Journal, I described the theory of such air-engines, and gave also a sketch of the construction of such a one as I conceived to be practicable.

My theory was based entirely on the principle of the conservation of energy, which had been advanced by Mayer and mathematically worked out by Helmholtz in his celebrated memoir "On the Conservation of Energy", originally read before the Physical Society. Later on my brothers William and Frederick occupied themselves a good deal with these engines, and constructed them in various forms. They too however unfortunately had to undergo the common experience of finding, that engineering had by no means advanced far enough to allow of the discovery being utilised with advantage. Only small engines could be constructed on the basis of the above principle so as to work well for a length of time; for large ones the right material for the heating apparatus was and-is still wanting.

In the same year I printed in Dingler's Journal. a description of the already mentioned differential governor, to which in collaboration with my brother. William I had tried to give the most varied forms. 
Another question. which had already occupied me for a long time, was that of an exact measurement of the velocity of projectiles. The watchmaker Leonhardt, known as a skilled mechanician and in the employ of the Artillery Commission, had constructed a clock, which turned an indicator with great velocity. when the latter was electro-magnetically connected with the clock-work.

The coupling and uncoupling of the indicator by the flying shot was attended however with great difficulties. which in spite of our efforts could not be quite overcome.

This led me to the idea of the employement of the electric spark for the measurement of velocity. In a paper: published in Poggendorff"s Annalen "On the application of the electric spark to the measurement of velocity", I demonstrated the possibility of accurately measuring the velocity of projectiles at every stage of their progress by means of a rapidly rotating polished steel cylinder, on which incident electric sparks conld leave a distinct mark. This paper also contained the plan. only many years subsequently executed by me, of ascertaining by the same method the velocity of electricity itself in its conductors.

My interest in electrical experiments was most vividly stimulated by participating in the labours of Leonhardt, who was at the same time occupied with experiments, which the military staff had caused to be instituted, with regard to the substitution of electric 
for optic telegraphy. In the house of Hofrath Soltmann, father of an intimate comrade of mine, I had the opportunity of seeing the model of a Wheatstone indicator-telegraph. and had taken part in the attempts to bring it into operation between the dwelling house and the establishment for artificial mineral waters at the end of a large garden. This however never succeeded, and I soon perceived the cause of these failures. It was traceable to the principle on which the apparatus was constructed. which required the turning of a handle with such regularity that the impulses of current produced had always sufficient strength to keep the clock-work of the receiving apparatus in motion. This was not attainable with certainty even if the apparatus worked in the room. and was altogether impossible where an important part of the current was lost through the imperfect insulation of the conductors.

Leonhardt. trying at the instance of the commission to remedy this defect, eaused the impulses to be produced by clock-work, i. e. in quite regular intervals, which was certainly an improvement, but still did not suffice with the varying loss of current. This made it apparent to me that the problem was most completely to be solved by converting the indicatortelegraphs into self-acting machines, each of which would antomatically break and make the circuit. If two or more of such electrical machines were connected to a single electrical circuit a fresh impulse could only be given when all the inserted apparatus had 
completed their stroke, and this had again closed the circuit. This proved in the sequel a very fruitful principle for innumerable electro-technical applications. All the self-acting alarums or bells employed at the present time are based on the automatic interruption after a completed stroke first introduced as above stated.

The construction of these self-interrupting dial telegraphs I entrusted to a young mechanician, named Halske, with whom I had become acquainted through the Physical Society, and who at that time managed a small mechanical workshop, the business firm being known as Böttcher \& Halske. As Halske at first entertained doubts whether my apparatus would act, I myself set up a couple of automatic telegraphs, composed of cigar boxes, tin-plate, a few pieces of iron, and some insulated copper wire, which worked with perfect certainty. This unexpected result filled Halske with so much enthusiasm for a design capable of execution notwithstanding such defective materials, that he gave himself up with the greatest eagerness to the construction of the first apparatus, and even declared himself ready to withdraw from his firm and in conjunction with me to devote himself entirely - to telegraphy.'

This success, as well as the growing care for my younger brothers and sisters, matured my resolution to quit the military service and through telegraphy, whose great importance I clearly perceived, create for myself a new vocation, which should also 
afford me the means of fulfilling the duties I had undertaken towards my younger brothers. I was therefore intent on the preparation of my new telegraph, which was to form the bridge to the new career, when an event occurred which threatened to throw all my plans to the winds.

It was a time of great religious and political stir in all Europe. This first found expression in Germany in the free religious movement which ran counter both to Catholicism and to the rigid Protestantism then in the ascendant. Johannes Ronge had come to Berlin, and held public lectures in the Tivoli Gardens, which were attended by all the world and excited great enthusiasm. The younger officers and officials in particular, then almost without exception liberally inclined, raved for Johannes Ronge.

Just as this Ronge-worship was at its height I along with all the officers of the Artillery workshop nine in number - happened to take a stroll after working-hours in the Thiergarten. "Under the Tents" we found many people assembled, listening to vivacious speeches, in which all the like-minded were called upon to take part for Johannes Ronge and against the obscurantists. The speeches were good, and were perhaps the more persuasive and captivating as people were not then accustomed in Prussia to public speaking.

When therefore on going away a sheet was presented for my signature, which was already almost filled with names partly known to me, I did not hesitate to add mine. The other officers, some con- 
siderably my seniors, followed my example without exception. No one dreamt for a moment of doing anything wrong. Each thought it only common honesty openly to avow his conviction.

But great was my alarm when at breakfast on the following morning I happened to glance at the Vossische Zeitung, and found a leading article entitled "Protest against Reaction and Religious Cant (Muckerthum)", and at the head of the subscribed names my own followed by those of my comrades.

When soon after - half an hour before the commencement of work - I appeared in the laboratory yard I found my comrades all assembled in a state of great excitement. We feared we had committed a grave military offence. In this supposition we were soon strengthened by the appearance of the commander of the workshops, an excellent and extremely amiable man, who declared to us in great excitement that we had by this action all ruined ourselves and him likewise.

Some anxious days passed. Then the announcement arrived that the inspector of the workshops, General von Jenichen, had to communicate to us an order in council. The order in council reprehended us indeed very severely, but was more gracious than we had ventured to hope. The general addressed us in a long speech, in which he set before us the impropriety and blameworthiness of our conduct. I was awaiting with some curiosity the conclusion of this speech, as I had taken the waters at Kissingen 
for a month with the general, who was a highly cultured and very humane man, and as I knew well that his opinions were not altogether different from those subscribed by us. "You know", said the general in conclusion, directing a look towards me, "that I am of the opinion, that every man. and particularly every officer, should always express his opinion openly, you have however not considered that openly and publicly are world-wide different things!"

We soon learnt that as punishment we were all to be sent back to our brigade - or our regiment, as it is now again called. For me this was an almost insupportably hard blow, disturbing all my life-plans, and making it impossible for me to go on providing for my younger brother's. The problem was to find a way to prevent this removal. That was only to be attained by an important military discovery, which should necessitate my presence in Berlin. Telegraphy, in which I was specially interested, could not perform this service, for only few then believed in its great future, and my projects were still undeveloped.

By good luck gun-cotton occurred to me, which a little while before had been discovered by Professor Schönbein in Basle, but had not yet been brought into use. It appeared to me indubitable that it could be so improved as to be made available for military purposes. I therefore went immediately to my old teacher Erdmann, professor of chemistry at the Royal Veterinary School, told him of my trouble, and begged permission to institute experiments with gun-cotton in 
his laboratory. He willingly granted it, and I went eagerly to work.

I had the idea, that by employing stronger nitric acid and by more careful washing and neutralizing a better and less easily decomposable product could be obtained. All the experiments however came to nothing, though I used fuming nitric acid extremely concentrated; a greasy easily destructible product was always the result. My stock of extremely concentrated nitric acid having run short I once tried the effect of adding some concentrated sulphuric acid in order to strengthen it, and to my astonishment got a guncotton with altogether different properties. After washing it became white and firm like the unchanged gun-cotton and exploded very energetically. I was overjoyed, made till late in the night a considerable quantity of such gun-cotton and placed it in the drying-stove of the laboratory.

When after a brief sleep I went again early in the morning to the laboratory I found the professor standing mournfully among ruins in the middle of the room. On heating the drying-stove the gun-cotton had exploded and destroyed the stove. A glance made this clear to me and showed the perfect success of my experiments. The professor, with whom I in my joy tried to waltz round the room, seemed at first to think I had gone wrong in the head. It cost me some trouble to set his mind at rest, and to induce him to resume the experiments at once. About eleven o'clock I had packed a goodly quantity of faultless 
gun-cotton, and sent it with a formal explanatory letter to the war-minister.

'The result was glorious. 'The minister of war' instituted a shooting-trial in his large gardens, and as it went off brilliantly immediately induced the heads of the ministry to make a regular trial with pistols. On the very same day I received an official order direct from the minister to repair to the powder manufactory at Spandau, which had already been instructed to place everything requisite at my disposal, to institute experiments on a larger scale. It is seldom I fancy that a memorial to the war office has been so quickly acted upon! Of my returning to the brigade there was no more talk. I was soon the only one of $m y$ brothers in misfortune, who had not been obliged to leave Berlin.

The experiments on the large scale, which were made under my direction in the powder factory at Spandau, did not lead to the result expected in the first glowing moments, viz. that gun-cotton would generally supersede gumpowder. It is true the trials with small arms as well as with cannon yielded excellent results; it appeared, however, that guncotton was not a sufficiently fixed combination, since it gradually decomposed in the dry state, and occasionally also would go off of itself. Moreover its effectiveness depended on the degree of compression of the guncotton and on the mode of its ignition. My report therefore ran. that the gun-cotton produced according to my method by means of a mixture of nitric and 
sulphuric acid possessed excellent properties as a blasting material, and seemed well suited to take the place of blasting powder for military purposes but that it could not in general be substituted for gunpowder, as it presented no sufficiently stable chemical combination, and its action was not constant enough.

I had already sent in this report when Professor Otto in Brunswick discovered anew and published my method of preparation of serviceable gun-cotton. My earlier action in the matter and my report to the war-office remained of course secret. and Otto therefore must rightly be held the discoverer of serviceable gun-cotton. since he was the first to make public the method of its production. It has often been so with me. It appears at first sight hard and unjust that any one may by earlier publication appropriate the honour of a discovery or invention, which another, who has worked at it long with ardour and success. would only make known after the most thorough testing. On the other hand it must however be admitted that some definite rule must be established in regard to priority, since for science and the world it is not the person, but the thing itself and its publication that is of importance.

After the danger of removal from Berlin had been in this manner successfully averted I was able to devote myself with a tranquil mind to telegraphy. I sent general Oetzel. the chief of the optical telegraph department under the immediate direction of the staff, a memoir on the condition of telegraphy and the 
improvement to be expected therein. In consequence of this I was ordered to place myself at the service of the commission of the staff, which was deliberating on the introduction of electrical instead of optical telegraphs. I succeeded in gaining the confidence of the general and his son-in-law, professor Dove, in so high a degree, that the commission almost always assented to my proposals and entrusted me with their execution. It was then regarded as altogether out of the question that a telegraph wire easy of access, attached to posts, could be really serviceable. since it was inagined the public would destroy it. Accordingly, wherever on the European continent it was desired to introduce electric telegraphs. experiments were first made with subterranean conductors. The best known were those of Professor Jacobi in St. Petersburc: he had tried resin, glass-tubes, and india-rubber as insulators. but had obtained no permanently satisfactory results. The Berlin commission likewise had begun such experiments, which however just as little yielded a satisfactory durable insulation.

By chance my brother William in London had sent me as curiosity a sample of a substance which had recently appeared in the English market, guttapercha. The remarkable properties of this material of becoming plastic in the heated state, and when cooled of being a good insulator of electricity, aroused my attention. I covered some pieces of wire with the heated material, and found that they were thoroughly insulated. At my suggestion the commission gave 
orders for more considerable experiments with such wires insulated by gutta-percha, which were begun in the summer of 1846 and continued in 1847. In samples placed on the track of the Anhalt Railway in 1846 the gutta-percha was rolled round the wire. It turned out however that the coil got loosened in course of time. I accordingly constructed a screwpress, by which the heated gutta-percha was cohesively pressed round the copper wire under the application of a high pressure. The conducting wires, coated by the help of a sampler press constructed by Halske, proved to be well insulated and permanently retained their insulation.

In the summer of 1847 the first long subterranean wire from Berlin to Grossbeeren was laid by me with such insulated wires. As it stood the test perfectly the question of the insulation of subterranean wires by the employment of gutta-percha and my press appeared to be now successfully solved. In fact since that time not only the subterranean land-lines but also the submarine cable lines almost without exception have been insulated in this manner.

The commission had under consideration the employment, both of the wires coated with gutta-percha by pressing and also my dial and printing telegraph, in the telegraph-system about to be introduced into Prussia.

The resolution to devote myself entirely to the development of telegraphy was now fixed. Accordingly; in the autumn of 1847 I induced the mechanician J. G. Halske, with whom our common labours had 
bound me elosely, to hand over his business to his partner and to start a telegraph factory, into which I J reserved to myself the right of entry on my discharge. As Halske just as little as I had available resources we had recourse to my cousin, George Siemens, a barrister residing in Berlin, who lent us 6000 thalers for the erection of a small workshop on condition of a share in the profit for six years. The workshop was opened on the $12^{\text {th }}$ of October 1847 in the back part of a house in the Schöneberger Strasse - where Halske and I also took rooms - and grew rapidly and withont the aid of outside capital into the worldknown establishment of Siemens and Halske in Berlin, with branches in many of the chief cities of Europe. The enticing prospect, in virtue of my dominating position in the telegraph commission, of rising to be the head of the future Prussian State telegraphs I had put aside, as a position of dependence was not congenial to me, and I had the conviction I should be of more service to myself and the world if I obtained my full independence. But I resolved not to renounce the military service, and therewith my place on the military commission, before the latter had completely accomplished its task, and a definite settlement of the future telegraph-system had been arrived at.

I urged in the commission that the public should also be allowed the use of the telegraph lines, which met with considerable opposition in military circles. The great celerity and certainty with which my new patented dial and printing telegraphs worked on the 
overhead line between Berlin and Potsdam and on the underground line between Berlin and Grossbeeren - performances with which those of the old semaphores were not to be compared - contributed however in no small degree to produce an opinion more favourable to the public interest. The report of the astonishingly favourable results of these experiments went the round of the higher circles in Berlin, and brought me a command from the Princess of Prussia to give a lecture in Potsdam on electric telegraphy to her son, afterwards Crown Prince Frederick William and Emperor Frederick. This lecture, accompanied by experiments on the Berlin-Potsdam line, and a memoir connected therewith, in which I enlarged upon the great future in store for telegraphy. supposing it to be made the common property of the people, no doubt considerably assisted in gaining over the higher circles.

At my instigation the commission instituted a public competition for March 1848, and settled the conditions to be satisfied in regard to the telegraphic communications and apparatus. Prizes were assigned to the conquerors, who were also to have the reversion of consequent orders. I had a pretty safe expectation of obtaining the victory with my own proposals at this competition, which opened on the $15^{\text {th }}$ of March 1848, when on the $18^{\text {th }}$ the competition as well as the commission itself came to an abrupt end.

Plunged in my own interesting labours I had found little time to give heed to the wild commotion, which since the February revolution in Paris was 
spreading over all Germany. With elemental force the mighty stream of political excitement rushed onward, tearing down all the feeble dikes which the existing power's aimlessly and planlessly opposed to it. Discontent with the prevailing state of things, the hopeless feeling that they could not be changed without violent subversion, penetrated the whole German people and extended to the upper strata of the civil and even the military administration of Prussia. The political e. and national claptrap, the emptiness of which was only revealed by the subsequent events. exerted its full effect upon the masses. and its diffusion was powerfully helped by the unusually fine summer weather, which prevailed throughout Germany at this time.

The streets of Berlin were continually flooded by excited crowds, discussing the most exaggerated reports of the progress of the movement, and eagerly listening to agitators who spread them further and called for action. The police seemed to have disappeared from the town, and the military, which did its duty with thorough fidelity, hardly made itself noticeable. Then came the overwhelming news of the victory of the revolution in Dresden and Vienna, closely followed by the shooting of the sentry at the Bank, and lastly the misunderstanding at the Castle Square. This drove even the quieter citizens, who had formed themselves into a mediating national guard, to the revolutionary side. I saw from my windows how a division of this citizen-guard came in great excitement from the Castle 
Square and threw their scarves and staves on the square before the Anhalt Gate with the cry "Treachery! the military have fired upon us!" In a few hours the streets were covered with barricades. the sentries were attacked and in part overpowered, and the struggle with the garrison. which for the most part confined itself to defence, and without exception remained true to their flag, quickly extended over a large part of the town.

I myself, owing to my being ordered to a special commission, was out of connection with the active army and awaited with beating heart the issue of the unhappy struggle. Then appeared on the following day the royal proclamation, which restored peace. On the forenoon of the $19^{\text {th }}$ of March the citizens crowded to the Castle Square to thank the King for his proclamation. I could stay no longer at home and accordingly mingled with them in civil dress. I found the whole square filled with a vast throng, which on all sides gave lively expression to its joy at the peace proclamation. But soon the scene changed. Long processions came, bringing the fallen to the Castle Square, in order, as was said. that the King might see for himself what havoe his soldiers had wrought. Then followed the terrible scene on the balcony of the castle. when the Queen fainted away as her eyes caught sight of the blood-stained dead heaped at her feet. There came fresh processions with corpses. and as the King no longer responded to the shout for his appearance, the excited throng prepared to burst 
Scene in the Castle Square on the $19^{\mathrm{Th}}$ of March.

open the castle gates, to make him see these dead likewise.

It was a critical moment, for to a certainty the struggle would have been renewed in the Castle Yard, where a batallion had been stationed, a struggle whose issue would have been exceedingly doubtful as the rest of the military had quitted the town by the royal order, had not a saviour appeared in the person of young Prince Lichnowsky. From a table placed in the middle of the Castle Square he addressed the crowd in a loud audible voice. He said His Majesty the King had in his great goodness and grace put an end to the struggle, in that he had withdrawn all the military and had entrusted himself entirely to the protection of the citizens. All demands would be granted, and they should now go quietly home. The speech manifestly made an impression. To the question from the people whether everything was really granted he answered - "Yes, everything, gentlemen!" "Smoking too?" sounded another voice. "Yes, smoking too" was the answer. "In the Thiergarten also?" — was further enquired. "Yes, you may smoke in the Thiergarten also, gentlemen." That was decisive. "Well then we can go home" was the general exclamation, and in a short time the cheered-up multitude left the square. The presence of mind, with which the young prince - probably on his own responsibility eonceded the liberty of smoking in the public streets and the Thiergarten, mayhap averted more serious. mischief. 
On me this scene in the Schlossplatz produced an ineffaceable impression. It showed with such unmistakeable plainness the perilous fickleness of an excited multitude and the impossibility of predicting its - actions. It taught me also that it is not usually the large and weighty questions that agitate the masses but petty grievances long felt by everybody as oppressive. The prohibition of smoking in the streets and particularly in the Thiergarten. with the constant petty warfare with gendarmes and watch-men connected with it, formed in fact about the only hardship really comprehended by the great mass of the Berlin populace, and for which it in truth contended.

With the victory of the Revolution all serious activity was put a stop to for a time in Berlin. The whole governmental machine seemed out of gear. The telegraph commission had simply ceased to do anything without being abolished or even only suspended. I owe it to the energy of my friend Halske, that our workshop quietly continued its activity during the hard times ensuing and manufactured telegraphic apparatus, although there was an entire lack of orders. Personally I was in a difficult position, as my official activity had ceased without any other being assigned me, and on the other hand it did not do to request $m y$ discharge at a time when it was generally assumed that a foreign war was imminent.

Then again, as so often in my life, an event occurred, which gave it a new and ultimately favourable direction. 
In Schleswig-Holstein the rising against the Danes had been accomplished with success. A powerful impulse was thereby given to the desire for national unity, and free corps were formed throughout Germany tor ender aid to the brothers contending against foreign oppressor's in the extreme north. On the other side the Danes made preparations for reconquering the land, and the Copenhagen newspapers with one accord called upon the government to punish the centre of the revolutionary movement. the town of Kiel, by a bombardment.

My brother-in-law Himly had in the previous year been called to Kiel as professor of chemistry, and resided close by the harbour. Sister Matilda wrote me in great anxiety and almost saw in spirit her house in ruins, it being especially exposed to the bombs of the Danish men-of-war. The marine battery Friedrichsort, as the small fortress at the entrance of the Kiel harbour was then called, was still in Danish hands; the entrance to the harbour stood therefore perfectly open to the Danish fleet.

This led me to the then entirely novel idea of defending the harbour by submarine mines fired by electricity. My wires insulated with gutta-percha offered a means of exploding such mines at the right moment in safety from the shore. I communicated this plan to my brother-in-law, who took it up warmly and immediately submitted it to the provisional government for the defence of the country. The latter approved of it and despatched a special 
emissary to the Prussian Govermment, with the request to grant me permission to execute the plan. My authorized employment or even mere leave of absence for this warlike purpose was however opposed on the ground that peace still reigned between Prussia and Denmark. But it was intimated to me that I should receive the desired permission if circumstances changed, as was expected.

I employed this waiting-time in making preparations. Large and particularly strong canvas-bags rendered watertight by caoutchonc were got ready, each capable of holding about five hundred-weight of powder. Further, wires insulated in all haste and exploding contrivances were prepared, and the necessary galvanic batteries procured for firing. When the departmental chief in the war-office, General von Reyher, in whose ante-room I daily waited for the decision, at last made the communication, that he had just been appointed minister and, war having been resolved against Denmark, that he granted me the desired furlough as the first act of hostilities against Denmark, my preparations were almost completed, and on the same evening I left for Kiel.

In Altona. where great excitement prevailed, my brother-in-law Himly already awaited me; a special locomotive took us to Kiel. The news of the declaration of war by Prussia had already become known, but was still considerably doubted. My appearance in Prussian uniform was rightly taken as evidence of the longed-for fact and excited on the whole way to Kiel and in the town itself unbounded joy. 
My brother-in-law in Kiel had meanwhile made all the preparations in order to proceed quickly with the laying of the mines, as the appearance of the Danish fleet was daily expected. A ship-load of powder had already arrived from Rendsburg, and a number of large casks stood ready well calked and pitched, in order to be provisionally used instead of the still unfinished caoutchouc-bags. These casks were as quickly as possible filled with powder, provided with fuses, and anchored in the rather narrow channel in front of the bathing-establishment in such a way that they were buoyed twenty feet under the surface of the water. The firing-wires were carried to two covered points on the shore, and the course of the current so disposed that a mine must explode if at both points simultaneously contact was made.

At both places of observation upright rods were set up and the instruction given, that contact must be made. if a hostile ship took up a position in the direct line of the rods, and remain made until the ship had again completely removed from the right line. If contact of both right lines were at any moment simultaneously made the ship would be exactly over the mines. By experiments with small mines and boats it was ascertained that this exploding arrangement acted with perfect certainty.

In the meantime the battle of Bau had been fought, in which the Schleswig-Holstein gymnasts and the German free-lances had been vanquished by the Danes and in part made prisoners. It is remarkable 
how quickly and potently the national hatred and the bellicose passions of the otherwise peaceful SchleswigHolsteiners now flamed out. This was strikingly exhibited in the temper of the women. A characteristic instance came immediately under my own observation.

At a social gathering a beautiful and amiable young girl made me explain to her the construction of the mines laid down for the protection of the town and the method of firing them. When she learnt that in a succesful case the whole ship would be blown into the air and the entire crew destroyed, she excitedly asked me if I believed that there were people who could perpetrate such an atrocity, and with the pressure of a finger annihilate hundreds of human lives. When I affirmed this and endeavoured to excuse it by the necessity of war, she turned indignantly away and obviously avoided me from that moment. When shortly after I again met her in society the battle of Bau had meanwhile been fought: Wrangel was on the point of marching into Schleswig-Holstein with the Prussian troops, and the war-fury had vehemently invaded the public mind. To my surprise my fair foe came directly up to me as soon as she caught sight of me. and asked whether my mines were still in order. I said "Yes" and added I cherished the hope of soon being able to show their effectiveness on an enemy's ship, for it was said that a Danish fleet was on the way for the bombardment of Kiel. I intended therewith to again kindle her wrath, which had shown her to such advantage. But to my surprise she said with counte- 
nance charged with hatred: "Oh, it would give me infinite pleasure if a couple of hundred of those monsters were to be seen sprawling in the air!" Her intended had been wounded at Bau and taken prisoner and was according to rumour being badly treated by the Danes along with the other captives on board the war-ship "Droning Maria". Hence this sudden revolution in her humane sentiments!

It was really said at the time that it had been resolved in Copenhagen to bombard Kiel. even before it was oceupied by the German troops. I was indeed somewhat anxious about the town. for the channel proved on exact investigation to be broader for ships of moderate size than was originally supposed. The Danish flect could also quietly drop anchor at Friedrichsort and effect the bombardment at their leisure by means of gun-boats. I considered it therefore of extreme importance that the Friedrichsort fort should not remain in Danish hands. It was said to be occupied by only a small number of disabled soldiers. its capture accordingly did not appear difficult.

I expressed my opinion to the newly nominated commander of Kiel, a Hanoverian major. He entirely agreed with me, had also received news that a Danish squadron was in fact on the way to occupy Friedrichsort. lamented however that he was without men. and therefore unable to do anything. When I mentioned the Kiel civic guard, who certainly would be willing, he doubted this indeed, but offered to have the drum beat and the civic guard informed of my proposal. 
The latter turned out in respectable number's, and I tried to prove to them that it was absolutely necessary for the protection of the life and property of the citizens of Kiel to occupy Friedrichsort, which to-day would be quite easy, but to-morrow perhaps no longer so.

My speech took effect. After a brief consultation the civic guard declared itself ready to take possession of the fort in the coming night if I would undertake the command, to which I of course willingly consented. Accordingly with the help of the commander of the town, who it is true had no men but a tolerably well-filled magazine at his disposal, an expeditionary corps of 150 men was hastily formed from the civic guard, supplemented by a reserve of 50 men.

Towards midnight we were on the way to Holtenau, whence the storming of the fort was to be attempted. My troops marched noiselessly and bravely on to the draw-bridge, which luckily had been let down, and with loud hurrahs we took possession of the fort. Resistance of any kind whatever unfortunately was not perceptible. I set up my head-quarters in the Commander's house, and soon the garrison, consisting of six old gunners and sergeants, altogether forgotten by the Danes as it seemed, was brought captive before us. The fellows were placed temporarily under arrest and on the following day as the first prisoners of war transported to Kiel; they were born Schleswig-Holsteiners, who manifestly were glad enough to obtain in this manner their discharge from the Danish army. 
At day-break I received the intelligence that a Danish man-of-war was lying in the roads, and soon after a spy was brought in, who had been signalling to it from the ramparts. It was a trembling old man, who was brought before me pinioned by powerful arms. On hearing the case it appeared that it was the garrison chaplain, who had found it too noisy in the otherwise quiet old fort, and who had therefore been giving the accustomed signal for a boat to the fishermen of Laboe, a village on the other side of the harbour-entrance.

The Danish war-ship remained quietly at anchor, sent a boat to Laboe and on its return went again to sea. I had hoisted on the fort a hnge black red and gold flag and manned the walls, so that the ship might carry the news to Copenhagen that the marine battery Friedrichsort was occupied by German troops, as was soon to be read in the Danish papers.

There now began a right cheery life in the fort. My citizen-troops did their duty conscientionsly. On organising the service I found to my surprise among the men members of well-known noble families of Schleswig-Holstein and respected citizens of the town of Kiel. They all however submitted implicitly to the command of a young Prussian artillery officer of their own selection. I had the ramparts cleared, the embrasures repaired, and the old cannons placed on such platforms as remained. The powder magazine was put in order and a stove erected by Kiel artisans for making the balls red-hot. I was especially assisted in 
this work by my man Hemp, (who without orders had followed me from Berlin,) an intelligent, able fellow, who subsequently accompanied me in all my telegraphic undertakings and finally became chief engineer of the Indo-European telegraph line, which position he occupied till last year. With his help the men serving a gun were hastily trained, so that on the third day after the occupation we could essay a first shot, which announced far and wide the military occupation of Friedrichsort.

On the following days we had many visits from Kiel. Not only the commander of the town and even a member of the provincial government paid us a visit, buta lso the wives and relations of the civic gnard came in great numbers, in order to be personally assured of the welfare of their friends. After the lapse of a week however my forces began perceptibly to shrink, as the wives in their visitings convincingly proved to their husbands that they were indespensable at home. I could not shut my eyes to the consideration that it would be impossible to retain in Friedrichsort for any length of time the citizens, who could only with difficulty be absent from their private business. On the other hand Holstein was still entirely without regular troops, and the feeble remnants of the Schleswig-Holstein force alone opposed the Danes who were again advancing into North-Schleswig.

I had therefore the choice either of abandoning my conquest or of procuring an equivalent for the civic guard. The peasant youth of the Provostry - the 
district over against the fort forming the south shore of the Kiel harbour - appeared to me particularly adapted for supplying this substitute. Accordingly, accompanied by a small body of the guard. I went with drum and flag first to Schönberg; the chief place of the Provostry, called the elders of the village together, and represented to them that it was altogether essential for their own safety that they should offer their grownup sons for the occupation of the fort. Then arose a long and difficult negotiation with the farmers and their wives, who placed themselves behind their lords and took a leading part in the conversation.

The people were of opinion that if "the gentlemen". viz. the government, considered it necessary that their sons should mareh, they could give orders to that effect: then one would know what one had to do. If the Danes actually invaded their land, the Provostry. then they would eertainly defend it. even without orders. but " in det Butenland up de annere Sid det Waters". in the outland on the other side of the water. they would not voluntarily go.

As the peasantry with loud approval of the female chorus remained immovable I became angry. I declared to them in the Low-German tongue, which I had not forgotten since my boyhood, that they were stupid asses and craven poltroons, and told them that the women in Germany had more courage than the men here. In proof thereof I read to them from a newspaper the statement that a female company had already been formed in Bavaria to protect the land 
against the Danes, as its own men had not the courage to do it. I would wait till they came, and defend the fort with them!

That had the desired effect. As I was on the point of departing with my little troop there came a deputation of the elder peasants and begged me to wait a little. they would think the matter over again, for they didint like the idea that the women should defend their country. I declared my willingness, but required, that the village should furnish at least 50 men. otherwise it would be no good. We were thereupon well fed, and an hour later there stood in fact 50 young men ready to go with us, followed by vehicles laden to the utmost with all sorts of provisions, "that their" youngsters might not have to starve in the fort". as the mayor's wife explained to me. Thus we proceeded from village to village with like result, and late in the evening I marched back to the fort with 150 stout peasant lads and a whole commissariat caravan.

I thereupon discharged the civic guard with the exception of a sprinkling of volunteers, who were willing to assist me in the direction and drilling of my peasant corps, and I had the pleasure of seeing a thoroughly serviceable troop turned ont in a short space of time.

Arms, ammunition and military insignia I obtained from the ever helpful commander of the town, whose name unfortunately has escaped my memory. My corps of volunteers was recognised by the provisional 
government, and also received the usual pay. In the military training of the folk my before-mentioned man Hemp, whom I named chief of the artillery, again rendered me signal service. The cannons were certainly old and bad, but a short 24 pounder and a howitzer were still serviceable: the Danish blockade ship, which no longer left the harbour-roads, seemed somewhat to respect the red-hot balls. which we always sent her when she came within range.

One morning we were alarmed by the announcement that three large Danish men-of-war were lying in the roads. It seemed indeed as if an attack on the fort were intended which, considering its bad condition and equipment. would have had the chances in its favour. The weakest point of the fort was the entry-gate opening on the inner harbour. The drawbridge was out of repair, the moat was dry. and the ravelin protecting the entry only remained in its outlines. As meanwhile my brother-in-law Himly had partially replaced the casks temporarily employed for the mines by the India-rubber bags that had arrived from Berlin, I ordered one of these now superfluous casks to be towed to Friedrichsort. in order to be there used as fougade for the defence of the fort gate. The day before the alarm I had had a deep pit dug in the middle of the old ravelin and the cask lowered therein. As night had come on before this work was finished, the pit remained open and was guarded by a sentry. When next morning the alarm occurred, I commissioned my brother Frederick - who. at 
subsequently my brothers William and Charles, had followed me to Kiel and Friedrichsort - to prepare the firing communication. to enable the mine to be exploded in case of an attempted storming of the ramparts.

The ships had now really approached within range. My three serviceable cannons were manned and the oven for heating the balls in full activity. I prohibited firing: however, before the ships forced the entrance. The rest of the men I had collected in the fortress-yard to distribute them and exhort them to bravery. when suddenly before the fort-gate rose a vast fire-sheaf. I felt a violent compression snceeeded by a violent expansion of the chest; the first sensation was accompanied by the clatter of broken window-panes, and the second by the elevation of the tiles of all the roofs to the height of a foot and their subsequent fall with a dreadful din.

Of course it could only be the mine, whose explosion had produced the mischief. I thought at once of my poor brother Frit\%. I ran to the gate to look after him, but before I reached it he met me uninjured. He had prepared the mine, set up the battery on the terre-plein. connected the one igniting wire with the one pole of the battery and fastened the other to the branch of a tree to have it ready to hand. and was about to announce this when the explosion occurred, and the atmospheric pressure hurled him down from the rampart into the interior of the fort. The rather violent wind har shaken the second firing-wire from 
the tree. causing it to fall just on the other pole of the battery and so producing the explosion.

With the sentry, who was standing on the breastwork of the ravelin when the explosion occurred. it had fared worse. I found him on the other side of the pit lying on the grom apparently dead. beside him his gun buried half barrel length in the earth bayonet forward. The powerful draught, caused by the mine exploding in the open pit, had evidently caught the man up and hurled him over the crater of the mine. Fortunately however he had clutched his gun convulsively, and thereby the blow in falling was mitigated. The man came again to his senses after the lapse of an hour: he bled indeed from mouth nose and ears, and then became blue over the whole body: but was otherwise minjured and after a few days again fit for service. The Kiel military doctor. who had hurried to Friedrichsort on the announcement of the appearance of the Danish squadron. and was crossing the drawbridge at the moment of the explosion. was more seriously injured. He was thrown with his vehicle into the rampart-moat and had received a few contusions. The cook too, who was just carrying up the steps of the ground-floor a bowl of soup and was thrown down by the explosion, was severely scalded.

Extremely remarkable were the mechanical effects which the explosion produced in a wide circuit. It must be considered as a shot from an open earthformed tube with a charge of five hundred-weight of 
powder. In the entire fort no space of any extent remained closed. Either the atmospheric pressure had pushed in the doors or walls, or where they resisted the ensuing vacuum had burst them asunder. The window-panes even in the village of Laboe and in Holtenau were broken. The differential pressure must in the interior of the fort have amounted to at least an atmosphere, otherwise it conld not have produced such effect at so great a distance.

When I returned to the place where I had left my troop I found it deserted, and feared that the people in their first terror had dispersed and crept away. I soon however saw to my delight that they had all betaken themselves to their assigned places. They had imagined that a Danish bomb had struck and the attack had begun.

The Danish ships had however determined to proceed no further. returned to the outer roads, and soon abandoned these also with the exception of the blockade-ship. In the Copenhagen newspapers it was shortly afterwards reported that one of the submarine mines, with which the harbour of Kiel was paved, had accidentally exploded and destroyed the fort. Indeed the view from the ships must have been rather astonishing. The red tiles of all the buildings of the fort protruded over the low ramparts, and rendered them particularly conspicuous. Immediately after the explosion however all the tiles had fallen down, and no houses were any longer visible.

That the Danes had acquired considerable respect 
for the mines is proved by the fact that in spite of the notorious weakness of the artillery defence of the Kiel harbour during both Schleswig-Holstein wars no Danish ship ventured into it. Although these first submarine mines never came into action they none the less accordingly played a very important part. I may therefore with justice complain that later military writers have completely ignored this first harbour defence by the help of submarine mines, carried out in view of the whole world and at the time much talked about. Even German military writers have subsequently ascribed the invention to Professor Jacobi in St. Petersburg, although his experiments at Kronstadt were carried out many years later; and he himself never dreamt of disputing my claim to the invention and its first employment in war.

When after conclusion of peace the mines were fished up and lifted, the powder in the caoutchonc bags was found still dry as dust, despite the two years soaking in sea-water. It is thus not doubtful that, had occasion offered, the mines would have done their duty.

Soon after the just described explosion in Friedrichsort the main body of the Prussian army under Wrangel entered Schleswig-Holstein. A little later I received a direct despatch from headquarters, in which I was commended for the harbour defence by submarine mines and for the occupation of the marine battery Friedrichsort. I was therein further apprised that a company of one of the recently formed Schleswig- 
Holstein battalions under lieutenant Krohn would undertake the permanent occupation of the fort, and was charged to march at a precisely appointed time with my peasant corps to the mouth of the Schlei. to cross it at a suitable place. and urge the population of the province of Angeln to seize Danish fugitives, who would there show themselves after an intended battle near Schleswig.

After being relieved by the Schleswig-Holsteincompany I marched at the appointed time to Missunde, crossed the Schlei at daybreak, and led my briskly marching troop towards Flensburg. At that early hour we already heard the roaring of the cannons near Schleswig. The population comported itself very calmly, and did not seem at all inclined to let itself be disturbed from its repose. No Danes were to be seen; we heard however in the evening from villagers that the Danish army had been defeated and was retreating by way of Flensburg pursued by the Prussians. In the neighbourhood of Flensburg this report was confirmed; the Prussian advance guard had already occupied the town.

As I had no further orders for my free-corps. and did not feel myself warranted in retaining the people longer, after the fort, for whose defence they had been recruited, was occupied by the military, I dismissed them to their homes, to which they hurried with all speed, and went myself to Flensburg, to deliver my report. 'That however proved extremely difficult as the greatest confusion still prevailed in 
Flensburg. The streets were completely barricaded with all sorts of vehicles. and no military or civil authority was discoverable. At last I stumbled in the throng upon Captain von Zastrow, well-known to me in Berlin, to whom I imparted my difficulty. He told me that he had received the command of a newlyformed Schleswig-Holstein corps. and had orders to march with it to Tondem on the following day. He was very much in want of officers however: and proposed that I should join him. and undertake the command of the battery. He would set everything formally right with the commander-in-chief and also take in charge my report to the same. This proposal particularly pleased me, as it would have been anything but agreeable to me to have been removed just then from the seat of war to peace-quarters in Berlin. I therefore wrote my report detailing the execution of my orders, and announced that I had discharged the volunteer peasantry and in the absence of further instructions was about provisionally to undertake the command that had been offered me of a Schleswig-Holstein battery. Accordingly I rode on the following day at the head of the battery assigned me over the sterile ridges of the "sea-girt" land towards Tondern. The joy however was not to last long. Arrived in marchingquarters, the commander handed me a despatch from head-quarters brought by estafet, according to which I was at once to report myself to the commanderin-chief. In consequence of this I requisitioned a vehicle, arrived towards midnight again in Flensburg, 
and reported myself at once at head-quarters. I was shown into a large room of the first hotel in Flensburg and there found seated at a long table a number of officers of all ranks and of every arm of the service. On the sofa at the narrow end of the table sat two young princes. whilst General Wrangel occupied the first place next the sofa at the end of one of the long sides. When I had delivered my report the General rose and with him the whole assemblage. as it was contrary to etiquette to be seated while the commanderin-chief stood.

The General expressed astonishment at my being there. as it was only a few hours since he had made out the order for my attendance. When I explained that I had turned back immediately at the conclusion of the march, he thought I must be very tired and should drink a cup of tea. At his express order I had to seat myself at his place and take a cup of tea, whilst the rest of the company to my great embarrassment remained standing. It gave me the impression that the commander-in-chief wished to use the opportunity, to show that he honoured merit without respect of rank, and to give at the same time a little exercise in etiquette. In the ensuing conversation the General expressed his acknowledgments for the protection of the Kiel harbour by submarine mines. as well as for the occupation of the fort of Friedrichsort. Further he said, it would now be necessary, to make the protection of Kiel harbour as strong as possible, and also to secure the harbour of Eckernförde 
by submarine mines. as he had the intention of entering Jutland with his whole army. When I replied that the Eckernförde harbour was too open and its channel too broad for resting its defence on mines. and that a few well-placed batteries could do this with greater certainty. a long discussion arose in the company with regard to the supposed superiority of marine artillery to land-batteries, in which I took leave to observe, that a battery of eight 24 pounders well-placed and protected by an earth-wall, using red-hot balls. might engage the largest man-of-war. I added, the assertion that a land-battery might be razed by a few broadsides from a man-of-war had not been proved, and no wooden ship could long withstand a fire with red-hot balls.

The final result of this audience was that the defence of the harbours of Kiel and Eckernförde was formally entrusted to me. I was nominated commander of Friedrichsort and received an open order to the commander of the fortress of Rendsburg, in which the latter was directed to comply with my requisitions of guns, ammunition, and men for Friedrichsort and the batteries to be set up at the harbour of Eckernförde. This order was duly complied with in Rendsburg it is true with some reluctance, as the fortress itself was very inadequately equipped for defence. Friedrichsort was now provided with serviceable cannon, and put as far as possible into a state of defence. In Eckernförde I erected a large battery for heavy 12 and short 24 pounders on the level shore, somewhat eastward 
of the town. and a howitzer-battery on the hilly land on the northern shore of the harbour.

Neither Friedrichsort nor Eckernförde came into serious action in this campaign, but in the following year the batteries set up by me at Eckernförde acquired renown by their victorious struggle with a Danish squadron, in which the line-of-battle ship Christian VIII. was set on fire and the frigate Gefion placed hors de combat and captured.

After the completion of the fortification of Friedrichsort and the batteries at Eckernförde my activity began to be somewhat monotonous. It was mainly confined to the watching of the enemy's blockade-ship lying before Friedrichsort, and the control of the shipping passing the harbour-entrance. The military commander of Kiel had forbidden the departure of trading-vessels without special permission, and had given the marine battery Friedrichsort orders in case of need to prevent it by force. This led to a small military engagement, which brought a little variety into our monotonous life.

One evening I crossed in the commander's boat the entrance of the harbour; to visit the Laboe battery which I had erected on the opposite shore, when a Dutch bark in full sail came towards me, with the manifest intention of leaving the harbour without giving the prescribed notification. I called to the captain to lie to and report himself, otherwise he would be fired on by the fort. The Dutchman and his wife, who appeared to compose the whole crew, did not however take my 
warning in earnest. on the contrary declared they were not going to trouble themselves about the prohibition. Whilst this negotiation was taking place there was a flash. however. from the fort-rampart, and a warning shot fell into the water close in front of the ship, as prescribed by the regulations. Nevertheless, the ship continued its course with full sails. Now followed from the fort, as well as from the Laboe battery shot on shot, to which was soon added a sharp fire from a military sentry, stationed on the shore. But the doughty Dutchman was not to be diverted from his object, and successfully clearing the harbour-mouth disappeared in the darkness of the night, that had meanwhile come on.

Fishermen who had been sent out found the ship on the following morning anchored outside the harbour entrance, and the crew busily engaged in making good the harm caused in particular by the musket-balls. The bravery of the Dutchman was very simply explained by the fact. that he had lashed the helm when he actually heard the balls whistling: and had prudently retired with his wife below the water-line, where both were completely protected. I myself with my boat's crew was entirely at the mercy of the balls, and could afterwards at any rate boast that I had once without flinching stood an artillery fire! For the rest I must confess that the hissing of the balls whizzing past did not excite in me precisely pleasurable sensations.

The Danish blockade-ship too brought us finally in the latter part of summer another interesting interruption of the monotonous fort-life. 
I received from head-quarters the communication that the free-corps under the command of the Bavariam Major von der Tann would attempt a night-attack on the blockade-ship, and also the order to support this undertaking with all the resources of the fort. Soon after von der Tann, with his adjutant. a Comt Bernstorff, presented himself to me. and took up his quarters in Friedrichsort. The free-corps collected at Holtenau, where also the boat-squadron was organized. which was to undertake the night-attack. The day before a parade of the free-company took place in the fortyard. which did not inspire me with much confidence in the success of the venturesome enterprise. The men were not, perhaps. wanting in conrage, but in discipline and calm resolution. Von der Tann and his adjutant endeavoured in vain to convert the wild confusion into military order.

The plan of the surprise proceeded from a man who had formerly held some subordinate post in the Danish marine. He was a Herenles, who had got his huge limbs into a gold-embroidered admiral's uniform of his own fancy, and incited the men with loudsounding voice to courageous deeds. Thus he asked the fellows standing in rank and file, what they would do when they had got on board and were confronted by the Danes. One declared he would stab the nearest man, another found it more fitting to knock him down, and so on. The "Admiral" listened quietly, then stretched himself to his full height and asked with flashing eyes and gestures appertaining thereto: "Do 
you know what I shall do? - I shall take the two nearest Danes and grind them on one another to powder!" That sort of thing dirl not exactly excite confidence in future heroic deeds.

The boat - squadron was to pasis the fort about half past eleven at night in the utmost stillness and without lights. and then proceed to the blockade-ship for the attack. when a signal given fiom the fort testified that the hostile ship was maintaining its wonted quiet. The signal was duly given: it was. however, about 1 o clock before the first boats had reached the fort. Then passed nearly two hours without anything happening. and at last the whole party retumed without any order and with loud din. The "Admiral" had at first not been able to find the blockarle-ship. then he declared he had observed that the ship was alarmed, and was provided with boarding-nettings. so that clearly the planned attack had been betrayed. With eries of treachery the expedition returned to Holtenau. and soon afterwards disbanded itself. On the following morning the ship lay in its accustomed place. and with the strongest telescopes no special armature against the threatened attack was to be observed.

As von der Tann confided to me, the undertaking had collapsed through want of discipline and too free stimulating potations, and he himself had lost the desire to make a further attempt. I was heartily sorry for the able and amiable Bavarian officers in this fiasco. Von der Tann remained for several days my guest in the fort, and I have in after years often 
remembered that agreeable time with pleasure, when the fame of the deeds of "General von der Tann" has reached me.

With my official appointment as commander of Friedrichsort, and the charge to provide for the defence of the harbour of Eckernförde by erection of batteries, my position had lost the somewhat adventurous character that had thus far clung to it. It had however also lost by that a great part of the charm which it had hitherto possessed for me. Particularly when I had fulfilled my tasks, and the commencement of the peace negotiations rendered further war-like activity very improbable, the longing took possession of me with ever growing strength for the resumption of my scientific-technical activity in Berlin.

In the meantime great changes had taken place there. The military commission for the introduction of electric telegraphs had been formally dissolved and telegraphy placed under the newly created Ministry of Commerce. As head of this department assessor Nottebohm had been appointed, who had already occupied an administrative post in the telegraph commission. The resolution was taken to follow the course adopted by the late commission, and first to construct in all haste a subterranean line from Berlin to Frankfort-on-the-Main, where the German National Assembly was holding its sittings. In consequence of this, an inquiry was addressed to me whether I was disposed to direct the construction of this line according to the proposals made by me to the commission. In the event 
of my acceptance my command from the war-office . would be transferred to the Ministry of Commerce. Although a position under assessor Nottebohm was not particularly agreeable to me. I nevertheless accepted the call, since it set me free from the present monotonous military life in the little fort. and gave me an opportunity of bringing my proposals into practical execution on a large scale.

In Berlin I found Halske already busily engaged in work for the line about to be constructed. It had been determined to lay the line altogether underground, as it was feared that above-ground wires would be destroyed in that time of great political excitement. The wires, insulated by a coating of gutta-percha, were to be laid without external protection in a trench a foot and a half deep in the railway embankment. My proposed protection of the communications by means of envelopes of iron wires, iron tubes, or clay channels was not approved on account of the great expense. A contract had already been signed with the Berlin india-rubber factory of Fonrobert \& Pruckner for the further construction of subterranean wires. This was the same factory to which I had transferred my model for the covering of copper wires with guttapercha, and which had already manufactured the experimental line from Berlin to Grossbeeren with a press made according to that model. I had to confine myself to providing for the best possible insulation of the wires. Considerable difficulties stood in the way however inasmuch as, owing to the sudden great 
demand for gutta-percha. the best insulating sort was soon out of the market.

To cope with this impediment to the rapid progress required of the work it was resolved to make use of the recent English invention of vulcanizing the gutta-percha, i. e. intimately mixing it with sulphur, whereby even with inferior kinds of gutta-percha the insulation of the conductors as well as their power of resisting external injuries was increased. Unfortunately the vulcanization turned out afterwards a mistake, as the sulphur combined with the copper of the conductor and thereby also the adjacent layers of guttapercha became gradually coppery and capable of conduction. To this circumstance it was mainly ascribable that the wires. though perfectly insulated at the time of their being laid down, had after a few months already lost a part of their insulation.

Particular care was taken in testing the wires in the factory. Halske manufactured for this purpose galvanometers which far excelled in sensitiveness all known up to that time. In testings with these sensitive galvanometers I observed for the first time in the year 1847 the surprising phenomenon that, even in a perfectly insulated wire lying in water, on interposing a battery a short current oceurred. which was succeeded on removal of the battery by an equally strong current in the opposite direction. This was the first observation of the electrostatic charge by galvanic chains. I was at first inclined to see in this a phenomenon of polarisation. since at that time the galvano- 
meter was not considered capable of indicating the passage of static electricity. 'The phenomena on longer well insulated lines soon however rendered it quite indubitable to me that it was a case of electrostatic charge and not of polarisation.

The first difficulty, the finding defective insulating points in a long piece of the conducting wire. I was able to overcome in the following mamner. The dry wire coated with gutta-percha was drawn through a ressel filled with water and insulated in respect to the earth. whilst the second coil of thin covered wire. which surrounded the electro-magnet of a Neef hammer. was interposed between the insulated copper wire and the earth. If now a workman standing in communication with the earth dipped a finger into the water of the insulated ressel. he felt electrical shocks at the moment at which a defective piece of the wire enveloped by gutta-percha was immersed. In this way I succeeded in detecting all the small defects of insulation discoverable in no other way, and in obtaining after their removal conductors with extremely good insulation.

With regard to the modification just described of the Neef hammer the following observation may here find a place. I had already made this modification in the year 1844 and given it the name of the voltaic inductor. It even then afforded me the opportunity of observing the therapentic feffect of the variable currents induced in the second coil of such a voltaic inductor. My brother Frederick at that time was suffering a' 
good deal of rhemmatic tooth-ache, which had affected his otherwise perfectly sound teeth and refused to yield to any prescribed remedy. The experiments with my new voltaic inductor led me to hit upon the idea of trying, whether the variable currents produced by it could not remore the intolerable pain or at least diminish it, if conducted through the roots of the teeth. This was actually the case with a particularly painful front tooth. The pain was at the first moment intense, but then suddenly quite ceased.

With the great force of will which at all times characterized my brother Frederick he at once proceeded to send alternating currents through all the roots. and thereby obtained entire exemption from pain. which he had not experienced for weeks. Unfortunately however on the second day the pains returned. By repeated application of electricity their cessation was again effected, but the ensuing painless. period became shorter, and at last the remedial agency altogether failed. This first attempt within my knowledge to employ galvanism for therapeutic purposes inspired me with a certain distrust of this particular application of the electric current. It appeared as if its action were only temporarily, not permanently, curative.

The ensuing autumn of 1848 was to me an exceedingly interesting and exciting one. The line to Frankfort on the Main, where the German Parliament held its sittings and the vicar-general of the empire had his residence. was to be completed for political reasons 
as quickly as possible. This was however rendered difficult on the one hand by the disturbed political condition of affairs, on the other by altogether unexpected phenomena, which manifested themselves in the underground conductors. My friend Halske, to whom had been consigned the fitting of the finished parts of the line with signalling apparatus. was the first to encounter these phenomena whilst I was engaged upon the line between Eisenach and Frankfort. which it had been resolved to carry above-ground. as the railway was still in course of construction - the land even having been only in part acquired.

Halske found first of all that with shorter lines our self-interrupting indicator telegraphs acted with much greater speed than corresponded to the resistance of the line. When communication between Berlin and Cöthen had been established, a distance of about 95 English miles, the giving apparatus ran with double velocity whilst the receiving apparatus stopped altogether. This at the time inexplicable phenomenon occurred the earlier the better the lines were insulated, which induced Halske purposely to impair the insulation of the line by the addition of artificial watery bypasses.

The above-ground construction likewise encountered unexpected difficulties. Where the land for the future railroad had not yet been purchased, the owners would not permit the erection of the posts. This opposition was encountered especially in the non-Prussian parts, Hesse-Cassel and Hesse-Darmstadt, when the antagonism 
between the government of Prussia and the administration of the empire after the restoration of order in Berlin had become considerably acuter in consequence of the entrance of the army returning from Schleswig-Holstein. I only snceeeded in executing my task by obtaining an open order from the vicar-general of the empire Archduke John. Technical difficulties also made their appearance. The line was constructed of copper wire, as suitable iron wires were not then to be had in Germany, and moreover were still regarded with a certain mistrust. The unfortunate experiences which we had had the foregoing year in the case of the Berlin-Potsdam line, which despite the application of all sorts of insulating media proved so badly insulated in rainy weather that the proper service of the apparatus was constantly disturbed, had led me to make use of bell-shaped insulators of porcelain. These possessed the great advantage that the inner surface of the bell always remained dry even in rainy weather, whereby the insulation was secured under all circumstances. In fact I succeeded in this way in producing an almost perfect insulation. Unfortunately I did not then think it necessary to solder the eopper wire. close coiling seeming to me sufficient. This afterwards turned out to be an error. In calm weather the apparatus acted very well, but with a strong wind the resistance of the conductor was so remarkably variable that the apparatus refused to work. Only subsequent soldering of all the joints put an end to this trouble. The atmospheric electricity proved also very 
disturbing. In passing from level to high land currents of varying direction often traversed the communications and impeded the working of the apparatus. A late autumn storm caused widespread destruction, which led me to construct lightning-conductor's for the protection of the lines and apparatus. In order to ascertain the most efficient form of lightning-conductors I set up between two parallel wires spikes. balls. and plates at equal intervals from one another. and observed the sparks, caused by the discharge of a large battery of Leyden jars. which passed between these three adjacent lightning-conductors. It appeared that very weak discharges took their course solely through the spikes, whilst stronger ones passed mainly between the balls, and very strong ones were carried off in a large number of sparks almost entirely through the plates. For actual lightning therefore roughened metallie plates placed nearly opposite one another proved particularly effective. The influence of the Northern lights also made itself frequently perceptible, and at times in a very disturbing degree, especially in the underground line running mainly from east to west. Thus during the great aurora in the autumn of 1848 communication was interrupted for days between Berlin and Cöthen on account of violent rapidly changing currents. This was the first observation of the connection between earth currents, magnetic disturbance, and the aurora borealis.

When the underground line had been extended to Erfurt, Halske's watery by-passes were no longer 
sufficient. But meanwhile I had become convinced that the peculiar behaviour of the underground wires could only be ascribed to the electrostatic charge already observed at the testings in the factory, the wire namely forming the inner. the damp soil the outer coating of a Leyden jar. Conclusive was the circumstance. that the quantity of electricity contained in a perfectly insulated conductor, measured by the deflection of a freely oscillating magnetic needle, was definitely related both to the electro-motive force of the interposed galvanic battery and to the length of the wire; further that the electric tension of the charge in a closed conductor corresponded to the electric tension occuring at every point of the circuit according to the law of Ohm. Having perceived this, the impediments to signalling on long underground lines, could, if not be removed entirely, yet be rendered innocuous for practical purposes by suitable contrivances. These were the application of by-passes in the form of metallic resistances without self-induction, and automatic translation by which several closed pieces of line were united into a single large line.

My theory of the electrostatic charge of closed as well as of open circuits found however even in scientific circles at first but little acceptance, since it was opposed to the ideas prevailing at the time. Altogether it is not easy at the present day, when one can hardly conceive how a civilized man can live without railroads and telegraphs, to carry oneself back in imagination to that time, with the view of under- 
standing the difficulties which we then encountered in things now regarded as a matter of course. Conceptions and helps, which are to-day familiar to every schoolboy. could at that time often only be obtained by effort and hard work.

I had the satisfaction of seeing this first long telegraph line - not merely of Germany but of Europe - already at work in the winter of 1849 , so that the election of an Emperor, which took place in Frankfort, was by its help known the same hour in Berlin. This favourable result led to the determination of the Prussian Government to construct at once a line from Berlin to Cologne and the Prussian frontier at Verviers, and after that others to Hamburg and Breslau. All these lines were for safety's sake to be underground, according to the system of the BerlinEisenach line, although in this ummistakable defects had already made themselves manifest. As these defects were mainly owing to the facility with which the wires were injured by workmen, and here and there also by rats mice and moles, through being deposited only one and a half to two feet below the surface in the mostly loose sand of the railway embankments, it was determined to bury the wires $\left.2^{1}\right|_{2}$ - to 3 feet deep; but even then there was to be no external protection on account of the cost.

I had declared myself ready to undertake also the superintendence of the construction of the line to Cologne and Verviers, provided I received further military fourlough and provided my friend William Meyer: 
who had always faithfully aided me in my work in his free time, and was therefore thoroughly competent, was ordered to assist me. Both were granted. and accordingly in the spring of 1849 we began the construction of the line simultaneously at several points. Meyer had considerable organizing talent, and was particularly adapted for managing works in which many forces had to co-operate harmoniously.

Difficulties arose at the rivers Elbe and Rhine. where the active navigation caused me to fear injuries to the wires through dragging anchors. This danger was particularly great in erossing the Rhine, as the conducting wires were for almost the whole breadth of the river threatened by the anchors and fishing-tackle. An envelope of iron wire, which was employed in the case of the Elbe and in crossing smaller rivers. appeared insufficient for the Rhine, as the tackle of the sailors and fishermen provided with sharp points could penetrate through the wire covering and injure the insulated conductors within, and as a cable could not be made strong enough to resist the dragging anchors of large ships. I had therefore made specially for the Rhine a chain of wrought-iron tubes. in the cavities of which the insulated wires were placed, whilst a strong chain-cable, supported by a series of heavy ships' anchors, was destined to protect the tube-chain from the dragging anchors of ships passing down the river. This first large subaqueous line with its external protection has stood the test very well. When many year's later, after the building of the 
fixed railway bridge, it was taken up again, a number of ships anchors were found suspended to the protecting chain, which the sailors had had to cut in order to free their ships. The chain had thus done its duty.

An extremely difficult and instructive piece of work was the construction of the line from Cologne via Aix-la-Chapelle to Verviers in Belgium, where the junction with the overhead line from Brussels to Verviers, which had meanwhile been taken in hand, was to be made. Here were several tunnels to be passed through, in which the conducting wires had to be protected by iron tubes attached to the tunnel walls. In large portions of the railway embankment the trench for bedding the wire had to be made by blasting with powder.

During the construction of the line I got to know the entrepreneur of the pigeon post between Cologne and Brussels, a Mr. Reuter, whose useful and profitable business appeared to be hopelessly destroyed by the laying of the electric telegraph. When Mrs. Reuter, who accompanied her husband on his journeys, was lamenting over this destruction of their business, I gave the couple the advice to go to London, and there set up a despatch-forwarding bureau, such as had just been etablished in Berlin by a Mr. Wolff, with the co-operation of my cousin the before-mentioned law-counsellor Siemens. The Reuters followed my advice with remarkable success. Reuter's telegraph agency in London and its founder, the rich Baron Reuter, have to-day a world-wide reputation. 
When the junction of the meanwhile completed Belgian telegraph-line with the Prussian had been effected in Verviers. I received an invitation to Brussels. to give a lecture before King Leopold on electric telegraphy. I found the whole royal family assembled in the Brussels palace, and delivered a long lecture accompanied by experiments. which they followed with close attention and quick understanding, as was evidenced by the discussion which followed.

The final decision of the question what tum I should give to my future life had now to be made. The military authorities had only with reluctance accorded the prolongation of my order for service with the ministry of commerce, and had emphatically declared that an extension of the same would not be granted. I had the choice either of stepping back into active military service, or of going over to govermmenttelegraphy, in which my position as managing engineer was assured, or lastly of renouncing every position of public service, and devoting myself entirely to private scientific and technical activity.

I decided for the last. To return to the military garrison service, after the exciting and successfully active life which I had behind me, I should have found altogether impossible. The civil service did not at all content me. There was wanting in it the feeling of comradeship, which mitigates and renders endurable the oppressive differences of rank and power. there was wanting in it also the plain-spoken candour, which reconciles one even with the bluntness, which is tra- 
ditional in the army. My brief experience of the civil service gave me sufficient grounds for the formation of this opinion. As long as my superiors understood nothing of telegraphy, they let me work entirely unchecked. and limited their intervention and instructions to questions of financial importance. That soon changed in the degree in which my immediate superior in office, assessor, afterwards counsellor Nottebohm, acquired knowledge of the subject during the progress of the work. People were assigned to me of whom I could make no use, technical arrangements ordered which I knew to be bad, in short frictions and differences occurred, which marred the pleasure in my work.

Again, the weakness of the insulated conducting wires. lying unprotected in the loose soil of the railway embankments, already began to show itself with increasing distinctness. Faults in the insulation made their appearance. which were only discovered and removed with difficulty: breaches of continuity in the wire without loss of insulation occurred, which often only lasted a few hours. and whose position therefore it was difficult to determine. The search for and repairing of these defects were commonly entrusted to inexperienced people. who cut the line in numberless places to confine the fault within limits, and by unskilful diggings and joinings paved the way for new defects, which were then again attributed to me and the system. Notwithstanding. with an almost blind confidence, new undertakings of the same description were entered upon. It may perhaps have been the political circumstances 
of the time, which called for the rapid construction of a telegraphic network to embrace the whole country. even at the risk of its not being of long duration. The external protection of the conductors by iron tubes proposed by me, as in crossing the Rhine, or by sheathing with iron wires, for the manufacture of which a Cologne firm had at my instigation already made preparations, was declared to be too dear and not readily producible: the provisional character of the first attempts was maintained.

On the other hand the factory for telegraphic apparatus, which I had founded along with my friend Halske, and into which I had reserved the right of entry, had already under his excellent management obtained considerable recognition by reason of its remarkable achievements. The great importance of electric telegraphy for practical life was perceived, - and the managers of railways in particular began to increase the efficiency of the lines and the security of their working by laying down telegraph - wires for intelligence and signals. In connection with this an abundance of interesting scientific and technical problems cropped up, which I felt a vocation to solve. My choice could therefore not be a matter of doubt. In

- June 1849 I requested my discharge from the military service, and soon afterwards also resigned my office as technical manager of the Prussian state-telegraphs. The latter post was offered at my suggestion to my friend William Meyer, who threw up his commission at the same time as myself. 
I had in the fourteen years of my military service with the then bad arrangements for promotion become the senior of rather more than half of the second lieutenants, and received therefore according to custom my discharge as first lieutenant "with the permission to wear officer's uniform with the regulation insignia for those placed on the retired list". I declined the pension due to me for my more than twelve years, service as officer, as I felt in good health and would not hand in the required invalid certificate.

To the acceptance of my request for dismissal was attached a remark of reprehension on a formal error in my petition. The political reaction had then become so strong that the German sentiments shown by me in the Danish war had become a reproach in governing circles.

In spite of the small final result of my military service I look back with a certain satisfaction to my military period. My most agreeable youthful recollections are connected with it, it paved my way through life, and gave me through the success I had achieved selfconfidence for aiming at higher goals.

Although my activity and aims were not materially changed by withdrawal from all official duties, yet my life acquired in consequence a more settled direction. henceforth dependent entirely on my own exertions. It lay with me now to raise to the utmost by good work 
the business which already bore my name, and to obtain

- personal regard in the world as a man of science as well as technologist. Although my inclinations drew me altogether to purely scientific investigation, yet I perceived that I must first of all turn my whole energies to technical work. as its results could alone procure me the means and opportunity for scientific work - and did in fact procure them.

My scientific and inventive activity was preseribed to me in this laborious period almost without exception by technical needs. Thus the then very surprising and disturbing phenomena of electrical charges in the underground conductors required thorough study. Further it was necessary to establish a system for the determination of the situation of faults in the conduction and insulation of underground wires by measuring currents at the ends of the wires. The uncertainty of the measurements of currents led to the necessity of replacing them by resistance measurements, and thereby to the setting up of fixed reproducible standards of resistance and scales of resistance. For this purpose the methods and instruments for current and resistance measurements had also to be improved and adapted for technical use - in short a whole series of scientific problems had cropped up, the solution of which was called for by technical needs.

I devoted myself to these problems, so far as my responsibility for the technical undertakings of the business allowed, with special predilection. and was therein very effectively supported by the constructive 
art and mechanical talent of my partner Halske. This is especially true of the numerous improvements of the telegraphic contrivances and accessories which date from that time, and which. thanks to their solid and accurate elaboration in our workshop under Halske's guidance, were rapidly adopted in technical telegraphy. The great influence. which the firm of Siemens and Halske has exereised in the development of telegraphy, is mainly to be ascribed to the circumstance, that in their work the executing hand has been that of the accurate mechanician and no longer as formerly of the clock-maker.

For publication in scientific and technical journals there was then no time: even patents were taken out only in rare cases. There was then no German patent, right. and in Prussia patents, given almost arbitrarily for from three to five years, were therefore without practical value. The inventions and improvements proceeding from us at that time therefore in the majority of cases lack the attestation of their origin by publication or patent.

A conspicious illustration of this occurred a few year's ago. There turned up somebody in the United States. who asserted that he was the inventor of underground conductors. especially of those insulated by gritta-percha, and who tried after the lapse of more than a quarter of a century to obtain a patent for the same, which threatened considerable loss to the large American telegraph company. The company sent a special commission headed by their director, 
"General" Eckert, to Berlin, to search for verification by printed publications that in 1846 I had already introduced wires with gutta-percha insulation. To their written enquiry I was obliged to reply that nothing was to be found in print on the subject, but that the official records of the Staff Commission and of the subsequent Telegraph Board contained proof complete.

This however did not suffice for the law-suit. The Americans chose another very practical way to procure printed information on the matter. They advertised in several German papers that they would pay a considerable sum for a description, printed in 1847, of the underground telegraph-lines laid on the track of the Anhalt Railway. That succeeded. After a few days there arrived from different places in Germany newspaper-cuttings with the desired description. The commission congratulated me as the undoubted inventor of the gutta-percha conductors and travelled home.

The proposed publication of the results however never came off, because, it is said, in the meantime a compromise with the reputed inventor had brought greater profit to the company.

In Germany, after the construction of the lines to Frankfort-on-the-Main and Cologne, the system of underground communications had become the fashion. Not only were the government telegraph lines from Berlin to Hamburg, Breslau, Königsberg and Dresden constructed underground with unprotected wires, buried at 
a depth of two feet, but even the railways preferred to lay such underground lines, although the indications of the speedy destruction of these lines increased daily. In particular the destructive action of rats and mice became more evident - especially on the first lines, which were laid in the sandy railway embankments one and a half to two feet deep. The wires laid over two feet deep were indeed at first exposed to no such destruction, but subsequently it occurred even in them.

I then believed that a coating of lead would completely cope with this evil. To coat the wires with lead I proceeded at first in the following manner. Leaden tubes were straightened out, then a hempen band was blown through them by means of a bellows, and with its help the conducting wire insulated by gutta-percha was drawn into the tube. Thereupon the tube was passed through a draw-plate, in order to effect a firm attachment to the insulated layer of the conductor. We afterwards succeeded in pressing the leaden tube directly round the insulated wire, when the lead had exactly acquired a certain temperature and permanently retained it. The difficulty of continually controlling this temperature I overcame by a thermo-electric arrangement.

Such conductors, surrounded by lead casing, were frequently furnished by Halske and me in the beginning of the fifties. So among others in the telegraphic system. which we set up for the police service and the fire-brigade of Berlin. These lead lines acted quite 
satisfactorily for a long series of years. They were then gradually replaced by cable conductors, yet lead conductors have remained in excellent condition to the present day, after the lapse of 40 years. Only where the lead has come in contact with decaying matter in the soil, whereby the formation of acetate and carbonate of lead is facilitated, is it liable to rapid destruction.

The just mentioned police and fire-brigale telegraph was intended to unite fifty stations in different parts of Berlin with the central office of the police department and the central office of the fire-brigade, so that the report of fire might be simultaneously communicated to all stations, whilst the police reports were only to be received and comprehended at the central police bureau. Onr arrangement solved this interesting problem very satisfactorily and worked for over twenty years well and accurately, but then succumbed to the simpler Morse system.

Morse s writing telegraph first became known in Germany through a $\mathrm{Mr}$. Robinson who, in the year 1850, gave exhibitions with it in Hamburg. The simplicity of Morse's apparatus, the relative facility of acquiring the alphabet, and the pride which fills every one, who has learnt to use it, and causes him to become an apostle of the system, have in a short time ousted all dial and older letter-printing apparatus.

Halske and I at once perceived this superiority of the Morse telegraph, resting on manual dexterity, 
and made it therefore our task to improve and perfect the system mechanically as far as possible.

We gave the apparatus good wheel-works with automatic regulation of the velocity, a reliable magnetic system. sure contacts and commutators. improved the relays. and introduced a complete system of translation. This consisted in an arrangement, whereby all the currents circulating in a telegraphic circuit were automatically transferred to a neighbouring circuit provided with its own battery. so that the whole line was divided into several separate closed circuits. but yet without the assistance of the telegraph clerks of the intermediate stations communication could be directly held between the terminal stations.

Such a system of translation I had elaborated as early as 1847 for my dial and printing telegraphs, and had laid before the Staff Commission an apparatus constructed by myself for this purpose, the so-called go-between (relay). Translation however only attained its full importance through the application to the Morse apparatus; it came into use for the first time on the Berlin-Vienna line, which was provided in Breslau and Oderberg with translation stations. It may be here mentioned that the contrivance was subsequently very considerably improved by Professor Dr. Steinheil, the then Director of the Austrian telegraphs, by fitting an antomatic contact to the wheel-work.

The railway companies remained longest faithful to the dial telegraphs with automatic interruption. In this system we had however ourselves brought 
a competitor into the field, who subsequently got a good deal in our way. Dr. Kramer, school-master in Nordhausen, had on his part submitted to the Telegraph Commission a small Wheatstone dial telegraph, which he had had made by a clockmaker. The Kramer apparatus did not by a long way accomplish as much as my self-interrupting dial telegraph, and was therefore rejected by the commission.

The good-hearted General von Oetzel and I myself felt compassion for the poor man, since he had employed all his savings on the construction of the apparatus; and as there were no means at the disposal of the commission for the indulgence of such feelings I consented to buy his apparatus for five hundred thalers. Half a year later however Kramer reappeared with a new apparatus, in which he had made use of my system, with the modification that he employed a clockwork to keep the pointer in motion mechanically. The patent office of that time saw no objection in the appropriation of automatic interruption to granting him likewise a patent. These Kramer dial telegraphs, running antomatically like our own, despite their light clockmaker-construction worked just as well and reliably as ours, and did us therefore great harm.

My time on entering the business was entirely claimed by constructive work for the factory. and by the laying down of numerous railway telegraph lines undertaken by my firm. Still in the winter of $1849-50$ 
I found a period of leisure, which I employed in putting together for publication my experiences on telegraphic communication and apparatus. In April 1850 I laid my work. with the title "Mémoire sur la télégraphie électrique", before the Paris Academy of Sciences. This had been rendered possible to me through a lucky accident, which enabled me to meet in Paris my friend du Bois-Reymond, who intended to present a work of his own to the Academy: and gave me his friendly assistance for the French remodelling of my essay. I still remember with great satisfaction the stimulating: and to me extremely interesting and instructive, time of this four weeks sojourn in Paris, the living together with friend du Bois, and the intercourse with the most celebrated Paris savants. To the members of the committee appointed by the Academy for considering my work belonged Pouillet and Regnault. The report on my memoir was read by Regnault at a sitting of the Academy, to which du Bois and I had received formal invitations. Leverrier appeared as opposer, and defended the electro-chemical telegraph of Bain, which had likewise been presented to the Academy. The presiding secrétaire perpétuel Arago however cut short Leverrier's opposition by moving the thanks of the Academy for the memoir and its reception in the "savants étrangers".

This public testing of my literary firstling in the telegraphic domain by famous members of the first scientific tribunal in the world produced a deep and very stimulating impression upon me. Many reasons 
can be offered against such an official trial of scientific and technical performances. which supplies a kind of hall mark and may easily be very injurious to the free unfolding of science: it is indeed only admissible under full control by the publicity of the séances, can then however be very useful and stimulative.

Through the admission of my memoir into the "savants étrangers", and another essay published the same year in Poggendorff"s Annalen "On electrical lines and apparatus". which reproduced entire the contents of the memoir so far as they had reference to underground electrical lines, my priority in respect of various scientific and technical achievements has been placed beyond dispute. Nevertheless unwarranted claims to certain of them were subsequently raiserl in divers quarters. This leads me to make here a few remarks on the need of an international literary tribunal. which has in recent times come to be felt with increasing acuteness. It must first of all be granted that in the course of the last decennia it has become ever more difficult, nay almost impossible. completely to survey the vast mass of material contained in scientific and technological publications, in many different languages moreover. It is also natural that those whoare entirely absorbed in their own special work. but especially those who actively co-operate in furthering the development of the technical application of physical science, find but little leisure to make a thorough study of the doings of others working on the same or on related lines, even if masters of the several 
languages, and that they in general have also little inclination to turn their attention to the past. As an example of this I might point to the most highly gifted and copiously inventive physicist of any age, Faraday. He got to know the insulation with pressed gutta-percha only many years after its invention. when it began to be employed in England for submarine cables, the external protection of the insulated conductor being secured by surrounding the latter with iron wires. The surprising phenomena of electrical charges. which Faraday observed in these cables. induced him to publish an essay on the subject. When du Bois-Reymond, however, sent him without further comment a copy of my memoir presented to the French academy. Faraday did not lose any time in following up his first work with another. in which he cited the relevant sections of my treatise. and made the declaration that the priority both of the observation and also of the explanation of the phenomena belonged to me. Other English writers, as Wheatstone, Jenkin and many others, have certainly not troubled themselves about either this declaration of Faraday's or any of my other publications.

In Germany the good custom formerly prevailed of always prefacing the description of one's own scientific or technical discoveries and inventions by a description of the achievements of predecessors in the same department, thereby giving the progress about to be described its place in the historic evolution a custom, which unfortunately has never been observed 
in other countries with like conscientionsness. Hence it has hitherto been the peculiar glory of the Germans to recognise more than other nations the services of foreigners, and always to connect their own achievements with those of their precursor's. 'This has been essentially facilitated by the knowledge, more diffised in Germany than in other countries, of foreign languages; but even apart from that German science has always regarded it as a point of honour to practise literary justice equally towards natives and foreigners. and let us hope that this will be so also in future, and that we shall thereby be spared the literary piracy which unhappily threatens to become prevalent even among ourselves.

As however the practice has recently come into vogue of leaving each individual to settle and defend his own real or supposed claims, this being too laborious for others, I intend to follow it in these pages. At the end of each period I shall accordingly give a summary of technical developments, important in my judgment, where the priority of discovery, invention, or first application demonstrably appertains $\checkmark$ to me. That in so doing I may here and there repeat what has been already adduced in another connection will certainly be unavoidable. Should I now and then make mistakes and pay insufficient regard to the claims of others. I must hope for the indulgence of the reader.

I shall be able to review with great brevity the period terminating with the publication of my "Mémoire 
sur la télégraphie électrique" and the corresponding paper in Poggendorff"s Annalen, as the most important particulars have been interwoven in the general narrative, and have thus already received detailed consideration.

When in the year 1842 I applied for my first Prussian patent no process of galvanic gilding or silvering was known in Germany.

I had experimented with all the gold and silver salts known to me, and besides the hyposulphites had also found the cyanides suitable. 'The patent however was only granted me for the former, as in the meantime Elkington's English patent for the employment of the cyanide salts had become known. Notwithstanding the beantiful gold and silver precipitates obtainable from hyposulphite salts, the cyanide salts have in the long run kept the field, their solutions being more constant.

The problem proposed to my brother William to construct a regulator. which should so exactly regulate a steam-engine connected with a water-wheel, that the water-wheel should always perform its full work, but the steam-engine yield the required excess of working power, led me to the idea of the so-called differential regulation. It consisted in employing a freely-oscillating circular pendulum for the production of a perfectly uniform rotation, thereby causing the turning of a screw. whilst the engine to be regulated turned a 
moveable nut on the screw in the same direction. The nut must then move right or left on the screw as long as it turns quicker or slower than the screw. and can thus perfectly regulate the pace of the engine. immediately ceasing to move, when the velocity of the engine is precisely equal to that of the circular pendulum. The differential regulator (or chronometric governor, as brother William, who practically elaborated and mainly perfected it, afterwards called it in England), constructed on this principle. has certainly not been largely introduced into practical engineering. It is neither so simple nor so cheap as the Wattregulator, which in later years has been considerably improved, but the differential movement, which we carried out in the most varied forms, has proved an exceedingly fertile element of construction.

My occupation with the problem of the exact measurement of the velocity of projectiles, imperfectly solved by Leonhardt's ingenious clock, caused me to perceive that only a method, in which no masses had to be set in motion and brought to rest. could lead to the goal. Thus I came to employ the electric spark for the solution of the problem. My proposal consisted in causing electric sparks to pass on to a rapidly and uniformly rotating polished steel-cylinder from a fine point approximated as far as possible to its periphery, and in calculating, from the interval between the marks produced by these sparks and the known number of revolutions of the cylinder, the velocity of the ball, which at particular stages of its 
career produced the sparks. 'This method of measuring velocity by the help of marks, which an electric spark brands on polished steel or sprinkles on sooty steel surfaces, has maintained its ground, and is still to-day employed especially for measuring the velocity of projectiles in large and small gun-barrels.

The suggestion of storing up the unemployed heat of one operation for use in the succeeding operation, derived from my brother William's description of the Stirling hot-air engine, which I received in the year 1845. interested me in a very high degree. It appeared to me to open the way into a yet unknown vast domain of technical science. It occurred at a time when the idea, pervading and governing the physical science of this age, of the causal connection of all natural forces unconsciously swayed men's minds, until it soon after became through Mayer and Helmholtz common scientific property. The principle of the circulation of heat in working engines and of the heat-equivalent of work already found clear expression in my paper "On the application of heated air as motive power" " whose publication was occasioned by Stirling's engine. I consider the chief value of this essay however to have been, that it incited my brother's William and Frederick to their later pioneer efforts in the province of thermal economy.

In my first dial telegraph of 1846 I consequentially carried out the principle of the automatic interruption of the electric current both for the apparatus 
itself and also for the alarum. The principle essentially consisted in increasing, according to requirement, the stroke of the well-known Neef hammer by the insertion of a moveable contact, the so-called slide. My dial and type-printing telegraphs, depending on this principle, were distinguished from the then well-known Wheatstone telegraphs by being automatic machines, running isochronally with one another, until one apparatus was mechanically stopped by the depression of a key on the particular letter, whereupon all the others likewise stopped at the same letter, and this letter was printed off by the type-printer. The description of these instruments, as of most of my further inventions and improvements of telegraphic conductors and apparatus down to the year 1850, is contained in my "Mémoire sur la télégraphie électrique" communicated to the Paris Academy. I content myself here with a concise summary of the most important scientific and technical improvements, the priority of which is secured to me by that publication:

Introduction of the automatic break of the electric current at the end of every movement of the armature through a predetermined distance. Or one may put it thus: increase of the movement of the Neef hammer by a mechanism answering to the slide of the steamengine. All automatic electric alarums without clock work and many other constructions rest on this principle.

Production of the synchronous action of two or more electric machines by allowing a fresh impulse to 
take place only when all the automatic contact-breakers are again closed, i. e. the armature-movement of all the apparatus inserted in the circuit is completed.

Manufacture of insulated conductors for subterranean or submarine telegraphs by coating wires with gutta-percha.

Construction of machines, which press the guttapercha without seam round the wires to be insulated.

Discovery of the phenomena of the charge in insulated subterranean or submarine conductors, and establishment of the law of the charge for open and closed circuits.

Establishment of the methods, measurements, and formulae for determining the place of faulty conduction and insulation in subterranean circuits.

The muderground wires, both those without external protection and those with an armature of lead, had meanwhile continued to come into use even beyond the confines of Germany; among other states Russia had adopted the system and connected St. Petersburg and Moseow by a subterranean wire. In Prussia however the deterioration, which had occurred in the first lines soon after their construction, continued to make uninterrupted progress. The causes, which contributed to this and finally led to the complete destruction of the lines, have been already mentioned. The almost morbid endeavour, called forth by political exigencies, 
to set up as quickly as possible and at the least cost a subterranean system of communication embracing the whole country, had prevented the provision of the wires with an armature and a sufficiently deep imberding: to secure them from injury at the hands of workmen and from the attacks of rodents. The attempt to replace the wires, thus rendered nseless, by others coated with lead proved fruitless, as the rodents gnawed to pieces even the protecting lead-covering. Further there was lacking a properly trained staff to keep the extended network of wire in good order, and to remedy defects without deranging the whole system. In consequence of unskilful searches and tinkering of faults numerous soldered joints came into existence, which were insulated in a very primitive fashion by patching with heated gutta-percha, and thus gave rise to new faults. It was therefore to be feared that the subterranean lines would, in a short time, become quite unserviceable.

This sad state of things moved me to write a pamphlet entitled "A short account of experiences in connection with the Prussian subterranean telegraph lines", in which I pointed out the existing risks and made proposals for improvements in dealing with the lines, but at the same time also energetically disclaimed responsibility, which was then on all sides sought to be fastened upon me, for the collapse of the system which I had suggested. It was only to be expected that the publication of this pamphlet would s lead to differences with the directorate of the Prussian 
state telegraphs. In fact for several years communieation of any kind whatsoever with myself and with my firm entirely ceased. All orders were withdrawn from us, and our special constructions handed over to other manufacturers as models. This constituted a severe crisis for our young establishment, which had rapidly risen to be a factory with some hundred workmen. Luckily railway telegraphy, which as the railways themselves was not then state property, furnished an independent market for our manufactures. The breach with the government telegraph management however had a good deal to do with turning our attention more abroad, and leading us to seek there a market for our products, as well as opportunities for larger undertakings.

As in the foreign undertakings of my firm, which I shall now have to report, my younger brothers played a very important part, it will be as well to cast a retrospective glance at the doings of my family and especially of my brothers during the period of my life just described.

The life of my brother William has been narrated at considerable length, and with the conscientious use of all the sources accessible to him. by a well-known English writer, Dr. William Pole. In what follows I need therefore only touch upon such events of his life as had immediate relation to my own. First I will here remark. that I stood during the whole of his life 
in active correspondence and lively personal intercourse with William, to our great mutual gain. We communicated to each other all the more important events of our lives, as well as new plans and aims; discussed our diverging views, and almost always, if not in our letters, yet at our next meeting, which usually happened twice a year, came to a friendly understanding. The circumstance, that I had paid more attention to pure science, and William to technology and practical engineering, led to each allowing to the other a certain authority in his own subjects, whereby our collaboration was considerably facilitated. That we were not jealous of one another, but rather rejoiced, when the one could further the recognition of the other in his respective country, strengthened and assured our good understanding.

After the dissolution of our commereial partnership for carrying out our inventions in the year 1846 William had entered an English machine factory of repute as engineer, with the object in the first place of securing a maintenance. But "the cat can't give up mousing", as a German proverb says: it was not long before he too was again buried in his inventions. The difference between us however was that I confined myself to the solution of the numerous problems, which telegraphy and in general the application of electrical theory to practical life brought me, William on the other hand tried by preference to solve difficult problems of thermo-dynamics. In particular he had set himself the task of overcoming the difficulties, which Stirling 
had encountered at Dundee in elaborating his hot-air engine, by introducing the heat-regenerator for the steam-engine. The experiments with these regenerating steam-engines, regenerating evaporators, and condensers claimed for years his time and means, without procuring for his constructions general introduction into technical practice. On the other hand he succeeded in practically solving a problem on which I had also long worked in Berlin with incomplete success, namely the water-meter question. The patented SiemensAdamson reaction water-meters for many years commanded the market and brought William good profits. Then they were superserled by the Berlin construction of the stroke or whirlpool meter, which was at once adopted by William himself.

The excellent progress which the manufacture of telegraphic and other electrical apparatus made in our Berlin factory, and the great recognition which our constructions on all sides enjoyed, suggested the opening of a business connection between William and the firm of Siemens \& Halske. He undertook at first to act as an agent for obtaining orders in England, and very cleverly contrived to turn the attention of English technologists to the achievements of the Berlin firm. This was especially furthered by the first Great Exhibition, which took place in London in the summer of 1851. Siemens \& Halske sent specimens in abundance; their exhibits found universal approval and procured for the firm the highest distinction - the Council medal. My brothers Hans and Ferdinand had remained 
faithful to their agricultural calling. After giving up the farming of the Menzendorf demesne they had come to Berlin, whither all the brothers with the exception of William had betaken themselves, and the two soon succeeded in obtaining suitable positions on Last Prussian estates.

Frederick had at a very early age gone from Lübeck to sea, and had for some years made a number of long royages in Lübeck sailing-ships. This had indeed somewhat cooled his originally invincible inclination for seafaring, and he wrote me one day that he would like to learn something. I bade him therefore come to Berlin, to prepare him by private instruction for attending a naval school. He devoted himself to his studies with great eagerness and success, and soon showed great interest in my own aims and experiments. The new mental life finally interested him in such a degree that the inclination for a sailor's life, whose seamy side he had got well to know, was incapable of withstanding the new impressions. Add to this, that the total change in dress, living, and climate, had brought on rheumatic sufferings, which he only slowly got the better of. Henceforth he assisted me in my technical work, and was strenuously bent on filling the great gaps which the seaman's life had made in his knowledge.

The next in order, brother Charles, had, like Frederick, spent the first years after the death of the parents with uncle Deichmann in Läbeck, and had then completed his schooling in Berlin. There he early took part in my work, and became my faithful ever 
reliable assistant in my first technical undertakings, in particular helping me in laying down the first underground wires.

I have already related that my brothers William, Frederick, and Charles, followed me in 1848 to Kiel and Friedrichsort. The powerful national feeling, that had everywhere been aroused in Germany, left them no peace at home. To William I entrusted the construction and command of the battery. which I had caused to be erected in Laboe opposite the Friedrichsort fort. whilst Frederick and Charles entered the service of the newly formed Schleswig-Holstein army as volunteers, and remained in the service till the conclusion of the armistice. On this occasion we arranged that Frederick should continue his technical education in England under William s guidance. Charles entered a chemical factory in Berlin, which he however soon quitted in order to assist me in laying down and repairing the telegraph lines. In the year 1851 he was together with Frederick the representative of the Berlin factory at the London Universal Exhibition, and carried on with ability the business negotiations which resulted therefrom. A branch in Paris, which we next founded under his management, did not bring indeed the hopedfor fruits, but contributed much to his social and business training.

Of the two youngest brothers Walter had come at the same time as Charles from Lübeck to Berlin and attended school there. Otto I placed in a grammar-school at Halle, as my time was too much 
taken up to allow of my personally superintending his education.

Of our two sisters the elder Matilda. married to Professor Himly in Kiel. was already the happy mother of a troop of pretty children. She has always honestly shared with me the care of the younger brothers and sister, and sought as far as possible to compensate them for the maternal love so early withdrawn from them. My youngest sister Sophia had been, as already mentioned, adopted on the death of our parents by uncle Deichmann in Lübeck. At the beginning of the fifties Deichmann took the resolution of emigrating with his family to North America. They were chiefly political reasons, which had oceasioned this resolution. After the suppression of the revolution in Germany and Austria, after the surrender of Schleswig-

s Holstein and the deep humiliation of Prussia a feeling of despair rapidly spread in Germany.

The power of Russia appeared then so gigantic, that the prophecy of Napoleon at St. Helena, in fifty years Europe would become either republican or Cossack, seemed already practically fulfilled. Although I myself was also deeply depressed by the turn things were taking in the political world, I could not subscribe to so pessimistic a view. I not only therefore rejected the pressing invitation of the uncle to accompany him to America, but also tried to prevent any of my brothers and sisters from participating in the emigration. In particular I refused my consent to the departure of my sister Sophia, in which I was strongly 
supported by her legal guardian Herr Ekengreen. Unfortunately however we had no power to detain Sophia, as she had been formally adopted by the uncle.

In these straits Cupid came to our help. A young lawyer in Lübeck, Dr. jur. Crome, had observed with pleasure the young girl growing up near him, and was only awaiting the dawn of womanhood to present himself as a suitor. The dire news of the intended emigration prematurely ripened his resolution. He begged the hand of the maiden of sixteen, and shortly before the departure of the adoptive parents the wedding was celebrated. We older members of the family have not repented having favoured this step. The young husband is said indeed, in his first married days, to have been terribly tormented by jealousy, because the young wife kept carefully locked certain drawers of her cabinet, even eagerly endeavouring on his unlookedfor entrance to conceal certain articles on which her attention was engaged. But then, on his impetuous demand, she tearfully confessed to him, it was the new dress of her favourite doll, for the completion of which the hasty wedding had left her no time!

It deserves to be remarked that the native characteristics of my brothers, as revealed in their earliest youth, have been faithfully preserved to an advanced age, and have given a well-defined direction to their career. This holds good especially of my three brothers, with whom a common life and aims have most united me, of William, Frederick, and Charles.

William had even as a child an abstracted, perhaps 
somewhat reserved nature. He clung with great affection to his relatives, but would never let them see it. From earliest youth he was ambitious and a little inclined to jealousy. When the tenderness of mother, grandmother, brothers and sisters was disputed by his next brother Frederick, a deep resentment against the little rival manifested itself - a feeling which I fancy was never wholly extinguished in him, in spite of all the fraternal affection and help bestowed so abundantly in later years. He possessed an extremely clear understanding and a quick power of apprehension, could always follow with great ease the train of thought of others, as well as grasp and give life to the spirit of what he had acquired. The good pupil developed with perfect consistency into the logical, methodical thinker, the able engineer and man of business. His great success in England he owes chiefly to his peculiar power of appropriating easily and quickly from the storehouse of German science what was of practical value for the moment, as well as to the further gift of having this scientific knowledge ever ready, and of always immediately discovering in the technical questions he met with the fulcrum, where the scientific lever should be applied for their furtherance or solution. No doubt he was essentially assisted by the circumstance that he came to England at a time when scientific culture was only represented there sporadically, although then in a remarkable degree, and when active co-operation between science and practice was as rare as in Germany. So he succeeded, not only 
in accomplishing good work limself, but also. by taking an active and energetic part in the highly developed life of scientific and technical institutions in England, in deserving well of the world of science, and at the same time in rendering a lasting service to English industry.

Almost diametrically opposite were the mental qualities of his successor in the series of surviving members of the family. Frederick was not a good learner. It has always been difficult for him to follow another's train of thought to the end. On the other laand he was from childhood a remarkably good observer, and had the gift of stringing his observations well together, and of making himself intelligible. Really to understand and appropriate the thoughts of others, he had to discover them or think them out for himself afterwards. This characteristic of steady, spontaneous, uninfluenced thinking and self-training gave him a peculiarly meditative air and his performances a pronounced originality. Frederick is the born inventor, to whose brooding mind the novel conception first presents itself in obscure nebulous form, and who thereupon with restless energy and untiring industry tests the foundation of the conception, filling up at the same time any gaps in his knowledge, and finally either rejects his idea as false or impracticable, or elaborates it into a serviceable and then almost always original invention. At the same time Frederick was never a diplomatist, and just as little a man of business carefully weighing his words and actions. He went and is still going everywhere his straight road, biased only 
by his innate friendly and benevolent disposition, a road which usually leads him to the desired goal, since he always well considers it and follows it with the greatest energy to the end.

I should call the next brother Charles the most normally constituted of us all. He was always to be depended upon, faithful and conscientious, a good pupil, an affectionate, attached brother. His clear eye and generally cultivated understanding made him an excellent man of business and, with his large technical knowledge and excellent tact, an admirable conductor of business undertakings. Charles was the true connecting link between us four brothers, who differed indeed radically from one another, but were bound together for life-long common work by all-subduing fraternal love.

Not to leave myself out in this family characterization I will only remark that I possessed a fair share of the good and bad qualities just described of my three brothers, but that these qualities were much repressed in outward manifestation through my particular line of life. To perform my duty and do good work has always been my strenuous endeavour. 'To find recognition has been indeed grateful to me. but it has always been repulsive to me to push myself in any way, or be made the subject of an ovation. Perhaps my constant endeavour "to be, rather than to seem". and to have my merits first discovered by others, was only a peculiar form of vanity. I shall try as far as possible to avoid it in these pages. 
The year 1852 formed a decided turning-point in my personal as well as in my business life.

At the beginning of that year I made my first journey to Russia. The business connection of my firm with the Russian government had been opened as early as 1849 through the medium of Captain von Lïders, who was making a circular tour through Europe, having been entrusted by his government with the task of ascertaining the best system of electric telegraphs. He then proposed our system for the line to be constructed from St. Petersburg to Moscow. Orders were given to Siemens \& Halske only for apparatus - dial telegraphs and measuring instruments - as the Russian Government took upon itself the construction of the underground wires. Negotiations having reference to further orders now required my presence in St. Petersburg.

My journey lay by way of Königsberg: which I had long ardently desired to visit, without having been able to make up my mind to undertake the journey. It was there that Drumann, the well-known historian, resided, who had married a daughter of my uncle Mehlis in Clausthal, and was accordingly my kinsman by marriage. In the year 1844 Frau Drumann had, on a journey to Clausthal, looked me up in Berlin, and spent a few days there with her youngest daughter Matilda. I made myself useful to the ladies during the time as cicerone, and passed some very agreeable and exhilarating days in their company. The return journey was to have been also by way of 
Berlin, and I was looking forward to the renewed meeting with my amiable cousin and her handsome and clever daughter. The pleasure was unfortunately destined to be marred by a very sad event.

Frau Drumann arrived ill in Berlin, and died in the hotel a few days after, of inflammation of the lungs. I was the only relative, even the only acquaintance of the family in Berlin, and had therefore to fulfil all the duties of the family head. My compassion was put to a hard test by the intense grief of the poor lonely girl. The speedy arrival of the deceased's brother, councillor Mehlis of Hanover. and of his wife made indeed easier for me the difficult and altogether unwonted task which had fillen to my lot, yet the image of the sorrow-laden girl, helplessly clinging to me, would not leave my mind. Eight years had since passed. in which our correspondence lively at first had gradually ceased. My brother Ferdinand had meanwhile become engaged to Matildais elder sister, and with the assistance of Professor Drumann had purchased the manor of Piontken in East Prussia. But when he was on the point of bringing home his bride, she fell ill of a chronic lung disease, to which, notwithstanding the excellent nursing of her only sister, she succumbed after several years of severe suffering. The time had now come for me to fulfil a long cherished wish, without departing from an earlyformed resolution, to marry only when my own resources permitted it. Halske had managed well. We had bought in Berlin extensive premises, 94 Mark- 
grafenstrasse, at the back of which a fine roomy workshop had been erected, whilst the front part, recently enlarged, yielded us excellent dwelling accommodation. For the wedding then there was only lacking the bride. and I was able soon after my arrival in Konigsberg. on my mother's birthday - the 11 th of January 1852 - to put the long deferred question to Matilda Drumann. whose reply made me an accepted and happy lover.

My business affairs did not allow of a long stay in Königsberg. as I was expected on the 20 th of January in Riga. where we had to establish telegraphic communication with the port-town Boldera. which was to be effected by means of a steel-wire cable spanning the broad Dïna.

At that time posting was the only mode of travelling in Russia. This was very well organized on the main roads, that is to say considering the circumstances. At a distance on an average of from twenty to thirty versts - a verst is a little more than a kilometer - substantial houses with stabling were erected on the post-roads. in which shelter and horses were to be had. if not already engaged, and the traveller was in possession of a govermment order to the post-masters. directing them to furnish horses for a preseribed journey on payment of the regulation fare. If possessed of such an order - called Podaroshna the traveller: supposing he had no private carriage, obtained a small four-wheeled peasant's cart, without springs covering or other luxury, drawn by three 
usually not bad horses, of which the middle one was harnessed in shafts, and the two outside ones yoked so as to face respectively right or left. In a proper "troika" the stronger middle horse has to trot, whilst the side-horses keep pace with a galop to right or left. The traveller has usually for seat his travelling trunk or a bundle of straw - and then, good speed, and away at a galop, which only ceases at the next station, if flying report has vaunted the traveller's liberality in the matter of tips.

Such a post journey requires experience. It is necessary to sit on the trunk quite loosely and bent well forward, so that one s own spine may form a spring to protect the brain from the violent jolts of the wheels on the usually indifferent roads. If this precaution be omitted, violent headaches are the infallible result. However one pretty quickly accustoms oneself to this mode of travelling, which also has its charms, even soon learns to sleep quite soundly in the rocking position, coping instinctively with all the unevenness of the road by judicious counter-movements. When two travellers make use of such a "telega" they usually lash themselves together by a girdle, in order that their oscillations may be so regulated as to prevent their knocking their heads together. For the rest I have found that "telega" travelling can be very well borne, if it is not overdone. Certainly it is said that these journeys have often been fatal to couriers, who have had to sit day and night for weeks together in their "telegas". 
The telega journey was agreeable and interesting enough as far as Riga. But there regular winter weather had set in, and the further journey could only be made in sledges. The Russian "kibitkas" are low and rather short sledges, which for longer journeys are completely closed with matting. The inner space is separated from the driver's box by a wall of matting: in which two small windows are fixed, which admit light sparingly to the interior. A mat-flap at each side of the sledge renders possible the rather difficult getting out and in.

As I travelled for the first time into Russia proper, knowing no Russian, I lad to look about in Riga for a travelling companion. In a newspaper advertisement such a person turned up, who possessed a kibitka and spoke German and Russian perfectly. As appeared when we were already on the road, this was an elderly merchant's wife of Riga, who sought in this way to cheapen her annual business trip to St. Petersburg. She had packed the sledge so full of straw and bedding that one could only lie down in it, and then had the mat-covering close over one's face. It had become bitterly cold, and the nearer we got to our goal the stronger became the dry keen north-east wind, which with $18^{\circ}$ below zero Réaumur mocked at the warmest wrapping. Then I learnt in Russian fashion to drink hot tea in great quantities, as soon as a station was reached, for only in that way could any warmth be obtained. When on the third morning we had reached the Narva station we fell victims to a little stratagem, which 
was often and in the most varied forms practised by the post-masters. The post-master declared with the greatest assurance that it was of no use to travel further. as at the stations before St. Petersburg all the horses had been appropriated for a great imperial bear hunt. Apparently touched by the loud lamentations of my Russian companion he finally offered to give us a pair of particularly powerful horses. which would bring us the same evening to St. Petersburg. The bargain was struck, and the crafty Russian imagined that he had by the fiction of the bear hunt secured the whole fare to St. Petersburg. Our subsequent adventures however foiled his scheme.

Our driver was a young fellow without fur and warm foot-rug. That he often stopped seemed to us intelligible. as he evidently needed a warm drink to avoid being frozen. At last however he never returned at all. I had to struggle out of the kibitka which, owing to my double furs, that yet did not prevent a rather severe numbness, was attended with difficulty. I then found our "Iswoshtchik" in a hut hard by" brandy glass in hand, which the rather suspicionslooking Jewish proprietor of the hut kept eagerly filling. When I drove the man back to the sledge with the necessary sensible admonitions, I observed unmistakable signs of a deeper understanding between him and the tavern-keeper who accompanied us. It came to me therefore by no means as a surprise when, soon after resuming the journey; my travelling companion suddenly uttered a loud ery, and called to 
me that her travelling trunk had just fallen from the sledge. She had immediately noticed the loss, as the trunk was fastened beside the driver on the box in such a way as to block the one small window. It was very difficult in our confined position to make the driver stop. At last I achieved this by breaking the second small window. laid hold of him and threw him down from his seat. The trunk was luckily found again: the rope. which serverl to fasten it. had undoubterlly been cut.

It soon became pretty clear that the driver was dead-drunk, as he repeatedly drove us into the roadside ditches. At last there remained nothing else for me to do but to mount the box. and take the reins from the driver's hands. He very soon after fell soundly asleep, and neither scolding nor cuffing availed to revive him. I for my part soon felt my feet becoming benumbed, and when I tried to change the reins found that both my hands had become quite frozen and immovable. It was still possible for me to drive the sledge again into the ditch, and to pull off my gloves with my teeth. With the sudden stoppage the driver had fallen from the box, and lay like a corpse at my feet. I could therefore quite easily perform two useful actions, viz. wash his head with snow and thereby also thaw my own hands. It lasted a good while before I felt the life return into them. Soon after the driver also began to show signs of life, in that he made grimaces and presently began to wail and implore forgiveness. So in the darkness of the night we were 
able to continue our way by walking beside the sledge. and finally reached Krasnoye-Selo, where we took up our quarters with the post-master. Our complaint against the post-keeper in Narva and in respect of the Iswoshtchik he settled next morning in a very curt fashion. He required from us the stipulated fare to St. Petersburg, then gave the Iswoshtchik a sound thrashing with his own hands until his strength was exhausted, and sent him back with this in lien of any payment to his master, whilst he drove us himself with his own horses on to St. Petersburg.

In St. Petersburg I was received in a very friendly manner by the merchant Heyse, an uncle of the poet Paul Heyse. I had first made the acquaintance of the Heyse family in Magdeburg. where, during my period of service as recruit. I had received much maternal sympathy and kindliness in the house of the widow of school-director Heyse, distinguished as pedagogue and as author of a German grammar. The Petersburg Heyse, a son of the school-director, had in his younger years gone to Russia, and had there raised himself to be a partner in one of the most respected commercial houses. The intercourse with the amiable, and still thoroughly German, family was made easy by Heyse's procuring a lodging for me in a hotel near his own residence on the island Wasili-Ostrow.

St. Petersburg with its grand site, its broad streets and large squares, and especially with its mighty river, the many-armed Neva, made a powerful impression on me. This was strengthened by the strangeness of 
the life of the people and the peculiar mixture of large palaces with small houses, for the most part entirely built of wood, in the broad interminable streets. Also the active sleighing, which in winter takes up the streets and almost entirely excludes the carriage traffic, produces a peculiar effect on the foreigner seeing St. Petersburg for the first time. 'The inability to understand the language, and to decipher a single inscription on street corners and shops, gives one also a feeling of forlornness and dependence, which it is difficult to shake off. All the more cheering on the other hand is the intercourse with one's compatriots, the extremely developed hospitable family life in the large foreign colony of St. Petersburg, especially the German, to which it is no mean advantage that the Baltic provinces of Russia have completely preserved their German nationality in the cultivated classes. The higher government posts were at that time for the most part filled by Germans from the Baltic provinces. This extremely facilitated the getting on both socially and commercially of a German coming to St. Petersburg. It was much in my favour that owing to Berlin introductions the scientific circles were thrown open to me. I received a cordial welcome from the most celebrated representatives of Russo-German science, of whom I will only mention the academicians Kupffer, Lenz, Jacobi and von Baer.

Unfortunately the agreeable, and for my business undertakings advantageous, intercourse was seriously 
140 Illness. The Kronstadt line. Again to St. Petersburg.

interrupted. One day I felt extremely unwell. In vain I sought recovery by Russian baths and similar selfprescribed remedies, and finally by an emetic which I was able to procure. After the unspeakably painful night which ensued I fortunately received a visit from friend Heyse. who pereeived the seriousness of my illness and sent his doctor to me. I had canght the measles. which were then raging in St. Petersburg. Severe inflammation of the kidneys followed, which chained me for some months to a sick bed, and from the consequences of which I had long to suffer.

Apart from this personal mishap the results of my journey were very favourable for the development of our business relations. We obtained the commission to lay an underground line from St. Petersburg to Oranienbaum with a cable junction to Kronstadt.

The construction of the Kronstadt line. and the necessity of organizing another representation of our firm in Russia. led me again to St. Petersburg in the summer of 1852 . I found there in a German merchant of the first gruild, Mr. Kapherr, a very suitable representative, who has contributed much by his activity and adroitness to the favourable results of our Russian undertakings: and I was able to come into closer connection with the department of public ways and communications, to which the construction and management of telegraph lines appertained.

My marriage with Matilda Drumann was celebrated on the first of October 1852 in Königsberg. After a short stay in Berlin we travelled to the Rhine and then 
to Paris, where my brothers William and Charles also just then happened to be. After the year's passed in anxiety and severe work I there enjoyed in full measure my young married happiness, enhanced by the familiar intercourse with the brothers. The sorrowful years by the sick couch of her beloved sister had much tried my wife. All the more delightful was it to me to perceive how the new happiness from day to day restored her earlier youthful freshness. That made me also young again, and obliterated the traces of excessive labour and prolonged sickness.

Alas this sumshine in my life did not last long. Soon after her second confinement Matilda began to ail. The germs of the terrible disease of which her sister had died, and which she had probably received during the long self-sacrificing period of nursing, now began to mature. A year and a half"s residence in Reichenhall, Meran, and other spas appeared to have restored her, but it was not for long. After a union of thirteen years, in which she bore me two sons and two daughters, she died after long and painful suffering.

When in the spring of 1853 the construction of a railway telegraph from Warsaw to the Prussian frontier was entrusted to us, we made my brother Charles, who had returned to London at the beginning of that year after the shipwreck of our Paris plans, the offer to undertake the direction both of this construction and also of the further expected works in Russia. Charles declared himself ready, and subse- 
quently executed these in part very difficult tasks so satisfactorily; that we considered our resolution to entrust him, despite his youth. with such important works as a very happy one. We owe it mainly to his energy and ability that the Russian business now grew so rapidly and to such proportions.

The emperor Nicolas was then on the throne. and under him the most powerful man in the empire was Count Kleinmichel. chief of the ministry of public ways and communications. I had up till then come into no personal contact with this man so feared throughout Russia, as the negotiations had been carried on through the above mentioned Colonel von Lüders, with whom I was on personally friendly terms. When however the latter was taken ill and obliged to try the restorative efficacy of German watering-places in the spring of 1853, I was summoned by Count Kleinmichel to St. Petersburg for a conference on telegraph matters, just when I was expecting my brother Charles, to accompany him to Warsaw. I accordingly applied as usual at the Russian embassy for the visa of my passport. To my astonishment, in spite of repeated reminders, I failed to obtain the visa. When I complained of this to the ambassador himself, he told me that by order of the St. Petersburg secret police the visa could not be given. As no reason was given for the refusal, nothing was left to me but to write to Count Kleinmichel that I could not comply with his request, the visa of my passport having been refused. It then lasted no longer than the exchange of couriers bet- 
ween Berlin and St. Petersburg, before an official from the Embassy handed me the visé passport with many excuses, and the explanation that a misunderstanding had occurred.

When however a few days later on the journey to Warsaw I had reached the Russian frontier station. I soon found that despite the alleged misunderstanding I still belonged to the class of suspects. My effects were searched, after all the other travellers had been passed, with a minuteness which far exceeded all expectation. Every written and unwritten piece of paper was retained, and it was finally declared to me that, in consideration of the excellent result of the search so far. I should be spared an equally thorough personal visitation if I handed up all my letters and gave my word of honour, that I carried nothing else about me printed or written. On my declaring that I should return, as such a treatment did not suit me, it was signified to me, that I must now go on with my luggage to Warsaw and there await a further decision. I was in fact a Russian state prisoner!

Arrived at Warsaw I complained bitterly of the treatment to which I had been subjected to General Aureggio, who as director of the Warsaw-Vienna Railway had concluded the contract for the construction of the railway telegraphs with my firm. The General promised to lay my case before the then Governor of Poland. Prince Paskewich. To his question whether I had done, written, or said anything, which could have rendered me politically suspected, I could only answer 
that I had once replied to a Russian state-counsellor, on his repeated offer to procure me a decoration for my services to Russia, that this would afford me less satisfaction than an order to construct further telegraph lines for Russia. The Gorernor had laughed heartily. when the General communicated to him the confession of my sin, and bade him tell me, he would in my place have thought just the same. I at once received all my things back and a passport to St. Petersburg. After being a short time with my brother Charles, who had meanwhile followed me to Warsaw, I accordingly continued my journey.

Arrived in St. Petersburg after a six days journey in an extremely uncomfortable stage-coach, I immediately repaired to Count Kleinmichel, who, as I had already heard in Warsaw, had himself issued the order on his own responsibility to give me the passport. The Count listened to my report in a quite friendly manner. and took a look at the testimonials in regard to the works hitherto executed by us which I laid before him. At the treatment which I had suffered he was manifestly very indignant. When, in a very favourable testimonial of the president of the Berlin police Hinkeldey in regard to the police telegraphs laid down by us, he found the concluding remark, that politically I was altogether free from suspicion, he bade me go with this testimonial to the chief of the secret police, General Dubbelt. "Tell the General" were his words, "I command him to read the testimonial, and then bring it back to me immediately, I shall show it to the Emperor!" 
This injunction placed me in rather an awkward predicament. Fortunately a Warsaw business - friend had given me an introduction to one of the higher officials of the dreaded department of the St. Petersburg secret police. I therefore went first to this gentleman, and requested to be advised how I should proceed, in order to do the count's bidding: and yet not give offence. From him I learnt, that a report from Copenhagen, in which I was described as a dangerous character, on terms of intimacy with the democratic professors of Kiel, had occasioned the refusal of the passport. Evidently it was Danish gratitude for the torpedoes in the Kiel harbour and the construction of the Eckernförde batteries, which had certainly rendered the Danes rather uncomfortable. Both the chief of the police, who in solemn audience received my testimonial and thereupon assured me of his special satisfaction and his constant readiness to help me in my undertakings, and also Count Kleinmichel himself were perfectly satisfied by these explanations.

I have related this interesting episode of my life in Russia at such length, because it gives a good picture of the state of things and official relations in the realm of the Czar at that time, and because it has been of great service to our business transactions. Count Kleinmichel's power was then so great, that, as long as the Emperor Nicholas lived, no one ventured to resist it. The count had acquired confidence in me, and afterwards bestowed the same in a very marked degree on my brother Charles. To his powerful 
protection alone did we owe it, that we were enabled successfully to execute the great works, which he entrusted to us.

Count Kleinmichel did not conceal from me, that he would have liked to have retained me altogether in Russia for the execution of his further plans. As I could not accede to that, I announced to him, when at the end of July I took my leave, the approaching arrival of my brother, who had great experience in the construction of lines and would be able to execute his orders better than I could myself. A few days after my departure Charles arrived in St. Petersburg. When he presented himself to the count, the latter was surprised at his youthful appearance. He evinced in consequence much annoyance, gave him however the order to propose an arrangement, whereby the wire of the telegraph in course of construction between Oranienbaum and Kronstadt might be conducted into the turret-room of the imperial winter palace, hitherto the terminal station of the optical telegraph to Warsaw, without disturbing the Emperor's dwelling house. When brother Charles looked attentively at the proud palace with the turreted projection, wherein the bureau of the optical telegraph was placed, it struck him that in one of the corners of the tower no gutter ran down, as was the case in the others. On perceiving this he immediately returned to the count, who, annoyed at his supposed fussiness, inquired rather roughly what else he wanted. Charles at once communicated the plan of placing in the vacant corner of the 
tower a similar tube to that which existed in the others, and of carrying up therein the insulated telegraph wires. That made an impression on the count. He inveighed against his officers, who could suggest nothing better than knocking out grooves in the masonry, "and now", so he expressed himself, "there comes a beardless young man, and sees at the first glance how easily the thing is to be done." - Thus Charles succeeded on his very first appearance in gaining the favour of the count, who from this moment onwards accorded him an authority, in which he placed as implicit a confidence as in my own. In this he was not disappointed.

In the autumn of 1853 Charles completed the Kronstadt cable-line to Count Kleinmichel's perfect satisfaction. This was the first submarine telegraph line in the world which has remained permanently serviceable. The gutta-percha conductors, protected by iron wires, employed for it have stood the test admirably. At the same time as the laying down of the line its maintenance, the so-called remount, was also contracted for by us for a period of six years. During the whole of this time the wire was only once seriously injured by ships' anchors, and after the lapse of the six years was handed over to the government in a faultless condition. It has remained in active use to the present time, and affords therefore a good proof of the durability of well-constructed submarine cables. In the spring of 1854 the Crimean war broke out. We received in consequence the commission, to 
construct as quickly as possible an overhead telegraph line along the high road from Warsaw to St. Petersburg or rather to Gatshina, which was already connected with St. Petersburg by an underground wire. Accordingly in April 1854 I travelled to Warsaw and there organised a working column, which began the construction of the line from Warsaw under the command of captain Beelitz, a former comrade of mine, who had entered the service of our firm. I then went to St. Petersburg and there together with Charles organised a second column, which under his command worked towards that of Beelitz from Gatshina. Thus the line about 1,100 versts long was completed in a few months, to the great astonishment of the Russians, who were unaccustomed to quick and well-organised work. When the two columns met half way at Dünaburg, and the translation-station of that place correctly performed its functions after the surmounting of a few difficulties, Charles was able to announce to Count Kleinmichel the completion of the line at the promised time. The count was much astonished at this intelligence, and would not quite believe in its correctness. He at once repaired to the station in the telegraph-tower of the Winter Palace, and himself addressed a question to the chief of the Warsaw station. His doubts were only removed when he had received an instantaneous reply, and astonished in the highest degree he announced the happy event to the Emperor.

The success of the Warsaw-Petersburg line strengthened the Russian Government in its resolve to 
cover the whole Empire with a network of electric telegraphs. The speedy construction of a line from Moscow to Kiev, between the former of which towns and St. Petersburg an underground line was already in operation as mentioned before, was entrusted to us. Then in quick succession lines from Kiev to Odessa, from St. Petersburg to Reval, from Kowno to the Prussian frontier, from St. Petersburg to Helsingfors, were ordered; which were all completed after overcoming infinite difficulties in the years 1854 and 1855 , and were of great utility to the Russian empire in the Crimean war raging at the time.

By means of the telegraphs Russia was put in speedy communication with Berlin and the west of Europe; in the interior of the empire the movement of troops and material could be regulated with their help, and the central government could everywhere promptly make and improve its arrangements.

Of the difficulties which beset the construction of these lines one may form an idea, when it is borne in mind that all the materials, with the sole exception of the wooden telegraph poles which were procurable in Russia, had to be obtained from Berlin and western Germany, that there were then no other railways in Russia than those from the Prussian frontier to Warsaw and from St. Petersburg to Moscow, and that all the roads and means of transport were occupied in an unusual degree by the war transports. In addition to this the marine transport of heavy materials from German to Russian ports was impeded 
by the blockade of the latter. With great difficulty two ships from Lübeck, loaded with iron wire for Russian ports, escaped capture through English cruisers, by taking refuge in Memel, whence their cargo was forwarded overland.

The Berlin firm had enough to do with procuring the materials, preparing the apparatus, and organising the transports, and was therefore only in a slight degree enabled directly to assist my brother Charles. on whose shoulders the whole burden of the construction of the line rested. Charles's chief assistants in the execution of these works were my former serving-man Hemp, who had rendered such effective aid in Schleswig-Holstein, and the half-pay captain Beelitz alluded to above. I myself was indespensable in Berlin, where meanwhile the construction of railway lines uninterruptedly continued, and was obliged to content myself with repeatedly journeying to St. Petersburg, to superintend organizing work and maintain the connection between the centres of our activity.

In the spring of 1855 I repaired to St. Petersburg for a somewhat longer stay in company with my friend William Meyer - who meanwhile had resigned his post in the Prussian government telegraph department, and had become chief engineer and confidential clerk of the firm of Siemens \& Halske - in order to introduce in our office there an organization answering the rapidly growing requirements. We had already nearly finished our work and were thinking seriously of our 
return, when I was suddenly called up at midnight and taken almost by force to Count Kleinmichel's assistant, General von Guerhardt. The latter imparted to me, that the Emperor had ordered the immediate construction of a telegraph line to the Crimea up to the fortress of Sebastopol, and the Count wished to have an estimate and the date of completion by 7 o'clock the next morning. My doubts in regard to the difficulty of procuring and transporting the materials on the only open road from Berlin to Perekop and Sebastopol, as well as to the impossibility of constructing a line to the seat of war itself, when all the ways and means of transport were required by the military, were overborne by that all-conquering word in Russia "The Emperor wills it!" And in fact the magic word held good also in this case. The line was made.

When after working the whole night I came to the General punctually at 7 o'clock, I learnt that the latter had been already summoned to the count two hours before, and had not yet returned. Soon after 8 o'clock he came and communicated to me, that Count Kleinmichel had told the Emperor, who had ordered the report by 6 o'clock, that I would execute the construction from Nikolaiev to Perekop in six weeks, that from Perekop to Sebastopol in ten weeks, and at the same price as the line from Kiev to Odessa. I declared both to be impossible. The transport of the wire and apparatus alone from Berlin to Nikolaiev on roads destroyed by the military transport would take at least two months. The expenses would also 
as a matter of course be much higher, and at the seat of war the work would be almost impossible for civilians and especially for foreigners. All that however was of no avail and was hardly listened to. The Emperor had spoken! In the course of the day I received an official letter, communicating that the Emperor desired to express his thanks to us for the services hitherto performed for Russia in its difficult situation, and for the offer of a rapid construction of the required line to the seat of war, but that he trusted we should, in consideration of the hard war times, construct the new line more cheaply than the previous ones.

That was an extremely difficult situation for us. The summer was already half gone, and before the end of it new material was in no manner of way to be got to the spot. Moreover without a heavy rivercable it was impossible to cross the broad and swampy Dnieper. And yet the imperial order had to be complied with, so far as in any way possible. The only possibility of effecting a telegraphic communication at least to Perekop, situated on the isthmus uniting the Crimea with the continent, consisted in collecting all the materials remaining over from the construction of the hitherto completed lines, sending them to Nikolaiev, and carrying the line in a circuit of about thirty versts by way of Bereslaw, where a bridge crossed the Dnieper, and made the passage practicable without a rivercable. The same night, in which the communication was made to me, we had accordingly corresponded 
by telegraph with all the Russian stations and had summoned to the station captain Beelitz, who luckily was just then in Nikolaiev, to settle the possibility of obtaining telegraph posts. Beelitz answered that he must first consult the Jewish timber-merchants, and had sent out messengers to summon them immediately to the station. Then arose a peculiar telegraphic negotiation. Beelitz announces a Jew would undertake the delivery of the poles, but must have fifteen roubles per pole. Answer: "Out with him!" Reply: "Done!" Another offers to do it for ten roubles. Answer: "Out with him too!" Reply: "Done!" A set of others ask six roubles; with these, negotiations are carried on and finally an acceptable offer is obtained, securing timely delivery of the poles.

Further it turned out that there was a reserve of materials in almost sufficient quantity for the line as far as Perekop, and that there was a prospect of obtaining in Odessa thin iron wires for a provisional line. There seemed therefore a possibility of satisfying the imperial will at any rate in essential points. With the request, to lower the price "in consideration of the present distressed state of Russia", we so far complied, that we offered to execute the necessary circuit by way of Bereslaw at our own expense. In short the omnipotence of the imperial command again prevailed. The line to Perekop was finished by the required time, and the line to Sebastopol was at least completed early enough for a message to St. Petersburg announcing the probable fall of the fortress. 
This construction of a line of about a hundred and forty miles on a road occupied and rendered impassable by marching troops and transports of war-material and into a beleaguered fortress was a difficult work, which did great credit to my brother Charles, who conducted it, and to his assistants. Financially it certainly ran away with a considerable part of the profits obtained through the construction of the other Russian telegraph lines.

I myself, after I had as far as possible made all the preparations for the construction of the line to the seat of war as ordered by the Emperor, and had become convinced that it was practicable, desired in July to return to Berlin, where my wife was expecting her second confinement. To my great astonishment I could however not get back my passport from the police, despite repeated applications. When I complained of this to Count Kleinmichel, he declared that I could not be allowed to depart before the lines in course of construction, and particularly that to Sebastopol, were completed. All my remonstrances were in vain. The count would not withdraw the order once given, to withhold the visa of my passport, and I was thus for an indefinite time "interned" — as it is called in St. Petersburg.

Then, luckily for me, the prince of Prussia came to St. Petersburg to negotiate, as it was said, concerning the neutrality of Prussia in the Crimean war. I determined to use this fortunate circumstance to slip from the semi-imprisonment into which I had fallen. 
I called at Peterhof, where the prince had taken up his residence, on his first adjutant Count Goltz, explained to him my difficult situation, and begged that the prince would when convenient give me an audience, so that the Russian officials might see that I enjoyed his protection. In his great goodness of heart and affability the prince acceded to my request, and on the very next day I received the official summons of the Prussian embassy to repair to an audience at the Winter Palace.

I was awaited by the ambassador, and conducted through a series of ante-rooms, filled with generals and officials of high standing, to the prince, who was surrounded by several Grand Dukes and highest dignitaries. The prince addressed a few very friendly words to me, mainly to the effect that the posts of the telegraph line we had constructed along the whole way from the Prussian frontier to St. Petersburg had given him the joyful assurance of remaining in constant connection with home, and that he desired to express to me his thanks in person. The result of this audience was more brilliant than I had expected. On the very same day a police official came and handed me my passport with excuses for the over-sight that had been committed. -

The Russian Government had simultaneously with the contracts for the construction of the lines also concluded remount-agreements with us for six to twelve years, which required a large administrative apparatus. We therefore converted our St. Petersburg 
office into an independent branch-establishment under the direction of my brother Charles, whom we at the same time took as a partner into the head firm.

We obtained a large building on the island of Wasili-Ostrow, in which the large offices of the administration of the remount were established, and at the same time a work-shop was erected for the speedy execution of all repairs.

Charles took up his residence there towards the end of 1855 after his marriage with the clever and charming daughter of our previous representative in St. Petersburg, the above-mentioned Mr. Kapherr.

Like his father-in-law, Charles now became a Finnish subject, in order to be able to become a merchant of the first guild, and as such to have the right of carrying on any kind of business in Russia.

I must mention one other circumstance, which was very important for our new St. Petersburg business and rendered it particularly remunerative. Count Kleinmichel had in the beginning entrusted the watching of the telegraph lines to the contractors of the turnpike roads, in consideration of a large payment reckoned by the verst. The result however was that no, or only a very lax, watch was kept. Accidental or intentional injuries to the lines were generally discovered only after the lapse of several days, and the repairing usually took place only after a long time and often so defectively, that a reliable service of the telegraphs was never to be reckoned upon. At last the count requested us to undertake also the watching of the 
lines, he rrould pay us for the service the hundred roubles per verst, which he had hitherto given to the road contractors. In reality a successful watch could not be carried out by us, it could only be done by natives, who would certainly not have kept a better look out on our behalf than for the Government. Nevertheless we accepted the count's offer on the condition, that we might carry out the surveillance and the necessary repairs entirely in our own fashion.

As this was accorded, we gave up altogether keeping a guard properly so called, contrived instead a mechanical system of control, which was relatively cheap and yet fully answered the purpose. At every fifty versts we erected a guard-hut, into which the wires were conducted. In the hut was placed an alarum and a galvanometer, which were intercalated into the course of the current in such a way, that the watcher of the movement of the galvanometer-needle could always see if an electric current was traversing the wire. If the needle stood still for half an hour, he had with the help of a simple mechanism to telegraph the number of his hut by repeatedly connecting to earth. The telegraph stations, between which the connection was interrupted, had orders to insert their battery between the conductor and the earth, and received accordingly the reports of all the guard-huts on the hither side of the place of interruption, thus learning its situation. To every telegraph station was assigned a mechanician, whose duty it was, immediately on the report of an interruption, to take post-horses 
and travel to the fault. As the order was given to supply our mechanicians with post-horses at once and before all other travellers, the fault was nearly always removed in the course of a few hours.

In consequence of this arrangement the Russian telegraph lines acted with great accuracy during the period of our management, and interruptions of the service rarely occurred for more than a day, in spite of the enormous length of the lines, and in spite of the desert steppes through which they mostly passed. The contract, almost forced upon us, for the watching of the telegraph lines soon proved very profitable, and amply compensated us for the losses which we had suffered in the construction of many of the lines.

Through the management of the remounts entrusted to us and the continued further constructions of lines our St. Petersburg business obtained great importance and a unique position in the Russian Empire. We received the official title "Contractors for the construction and remount of the Imperial Russian telegraph lines", and obtained for our superior servants the right to wear uniforms with badges of rank. 'The latter' was absolutely necessary for the thorough performance of our tasks, for the Russian public only respects the wearers of uniforms. To obtain this right I had a number of handsome uniforms designed in Berlin. Instead of the epaulets, which in Russia were reserved for officers, golden chenille of varying thickness, increasing with the rank, was attached to the shoulders. Excellent artists then painted various groups arrayed in such 
uniforms. The pictures, enclosed in a handsome portfolio, made the heart of every admirer and connoisseur of uniforms beat quicker. Armed with this portfolio, brother Charles repaired to Count Kleinmichel, explained to him our difficulty, and begged permission for the wearing of a uniform by our officials. The sight of the fine pictures conquered the resistance offered at first by the count; he retained the portfolio to show it to the Emperor, who immediately granted the permission for the proposed uniform.

I consider it my duty to meet in this place the often expressed opinion, that we could only have concluded these great and generally speaking profitable undertakings in Russia by the help of bribes. I can asseverate that this was never the case. The explanation may perhaps be that the negotiations were always conducted and concluded directly with the supreme government authorities, and that the state of political affairs urgently demanded the speedy construction of the needed telegraphic communications. This however does not imply that we have never recompensed the lower officials in the customary fashion of the country for services rendered during the construction the lines. 
Harzburg, June 1890.

The successful use of copper wires coated with gutta-percha as underground conductors suggested their employment also for submarine telegraphic communication. That sea-water was not in any way injurious to the gutta-percha had been proved in the case of the insulated wires connected with the torpedoes in Kiel harbour, which were quite unchanged after the lapse of two years.

The first attempt to connect two sea-coasts by means of gutta-percha conductors had been made as early as 1850 by Mr. Brett, who had obtained a concession for a submarine telegraphic communication between Dover and Calais. The unprotected wire laid by him retained its efficiency, as was to be expected, not much longer than the time of the actual laying, if indeed it was ever really serviceable. It was replaced in the following year through Messrs. Newall \& Gordon by a conductor armed with iron wires, which acted well for some time. This was the commencement of submarine telegraphy, destined speedily to become one of the most important media of communication. 
With the perseverance characteristic of the English in prosecuting their undertakings, the laying of a large number of other cables was, after this first success, at once planned and attempted, before the problem was ripe for a scientific and technical solution. Failures accordingly could not but occur. The laying itself presented no difficulty in the shallow water of the North Sea. The preparation of insulated conductors was undertaken in England by a gutta-percha company, which could not be prevented from employing my coating process, since I had not protected my inventions by a patent. As this company could always make use of the best quality of gutta-percha, owing to its command of the English market, it would have been in a position to turn out remarkably well-insulated conductors, if the electrical testing and control of the workmanship had been carried out with as much care as we had taken. Scientific knowledge and methods were however at that time as little appreciated in English industry as in our own. It was thought enough to make sure that a current traversed the wire, and that the instruments worked satisfactorily. Even much later my methods for a systematic testing of the conducting wires were characterizedby English engineers as "scientific humbug!" Nevertheless the firm of Newall \& Co. succeeded in the year 1854 during the Crimean war in laying an unarmed conducting wire, insulated only by a coating of gutta-percha, from Varna to Balaclava in the Crimea, and with the good fortune that it remained serviceable till the capture of Sebastopol in September 1855, i. e. for about a year. 
In this long line of about 400 miles difficulties in the matter of signalling occurred through the electrical capacity of the line, which in spite of my publications in 1850 remained entirely unknown to the English. When the needle telegraphs employed in England refused to do their duty on the line, Newall \& Co. ordered signalling apparatus from my firm, with which operations could very well be carried on. It was a singular coincidence that in the two hostile camps of Sebastopol and Balaclava Berlin apparatus with consecutive numbers of manufactur weere at work.

Meanwhile in September 1855 Mr. Brett, commissioned by the Mediterranean Extension Telegraph Company, had made the attempt to lay a heavy cable with four conductors between the island of Sardinia and the town of Bona in Algeria. He employed for the purpose the same contrivances as in the North Sea, but unfortunately his brake apparatus did not suffice on reaching deep water, and in consequence the whole cable rolled to the bottom without the possibility of detaining it. When a second attempt in 1856 also miscarried, he retired from the undertaking, which was then taken up by Newall \& Co. The latter contracted with my firm for the delivery of the electric apparatus, and requested me to undertake the electrical testing on and after the laying.

This first laying of a deep sea cable was both interesting and instructive to me. At the beginning of September $1857 \mathrm{I}$ went at Genoa with an assistant and the necessary electrical apparatus on board a 
Sardinian corvette, which was to accompany the expedition and take us to Bona, where the steam - ship laden with the cable awaited us. It was an interesting company which met on board the war-ship. Besides the English contractors and cable manufacturers, Mr. Newall and Mr. Liddell, there were on board several Italian savants, telegraph officials, and naval officers, among them the learned admiral Lamarmora, a very amiable and well-instructed officer, brother of the well-known General Lamarmora; further several French telegraph officials, who were commissioned by their government to be present at the laying of the cable, in particular the well-known engineer Delamarche.

Already on the passage to the island of Sardinia, which was favoured by gloriously calm weather, the party discussed the methods which should be adopted in laying the cable, in order to avoid the failure of previous attempts. Messrs. Newall and Liddell declared that in laying their wire to the Crimea they had found it best to proceed quickly, and let the cable run out without check, when it would sink slowly to the bottom without any strain. They had indeed for precaution's sake provided a powerful brake-wheel, to regulate the speed of the cable, but that would hardly be necessary if the ship was going fast. This theory of Mr. Liddell was strongly opposed by M. Delamarche, who had been present at the unfortunate attempts of Mr. Brett, and had now adopted the theory, that the cable must perforce assume the form of a catenary curve in deep water, and under any circumstances break. 
I had originally intended to abstain from interfering in the mechanical part of the proceedings, but it appeared to me so utterly impossible to lay a heavy cable, having a weight in water of at least $4 \mathrm{lbs}$. per yard, at a depth of more than 1500 fathoms (as was the case between Sardinia and Bona), in the manner intended by Messrs. Newall \& Liddell, that I spoke very earnestly against the proposal. On the other hand I could not share the fears of M. Delamarche, and there ensued a warm discussion between Mr. Liddell, M. Delamarche, and myself, in which I expounded the theory, which was subsequently universally adopted. It consists in holding back the cable by brake-apparatus with a force which corresponds to the weight of a piece of cable in water reaching perpendicularly to the bottom. With a uniform motion of the ship the cable then sinks in a straight line, the inclination of which depends on the ship's speed and the velocity of subsidence of a horizontal piece of cable in the water. If the sinking portion of the cable is not perfectly balanced by the force of the brake, a sliding down of the cable takes place at the same time on the inclined plane which it itself forms; it is therefore possible to regulate by the brake the extra amount of cable that is required to lay the cable without strain over the unevenness of the bottom.

This simple theory met with the universal approval of the company. Mr. Newall too came over at last to my view, and requested me to assist him in the preparations for laying the cable in accordance with 
my theory. It was however difficult to do this on the spur of the moment. The brake, which we found on arriving at Bona on the cable-ship that already awaited us, proved much too weak for balancing the weight of the cable at great depths. Moreover the steam-power of the ship was too small to overcome the great force with which the cable would endeavour to slide down the inclined plane. Finally there was no contrivance for measuring this force, and for determining accordingly the amount of the brake action required. I first had a simple dynamometer constructed by the carpenter, which rendered it possible to ascertain the extent of the actual strain on the cable while it is paid out by the amount of flexion of a length of the cable stretched over two rollers, between which a third weighted roller rides on the cable. Furthermore I had the brake-wheel strengthened as far as possible, and furnished with strong water-boxes. Lastly I caused the captain of the war-ship to pass a tow-rope from his vessel to the bows of the cable-ship, in order to obtain the requisite force for overcoming the backward drag exerted by the cable.

Thus barely provided, we began in the evening the laying of the cable from Bona. As long as the water was shallow all went well, and my precautions were soon deemed superfluous. After a few hours, when we got into much deeper water, it appeared however that the attainable brake force was not sufficient. We paid out too much cable and, when morning dawned, had already used more than a third of the cable, 
although a fifth of the distance had not been traversed. It was still just possible to reach with the cable-end a shallow spot near the island of Sardinia, if the cable could from now be paid out without any excess whatever. At the request of Mr. Newall I undertook to try this, on condition that the management was entirely left to me. I now loaded the brake with all the weights which were to be found on the ship. Even filled water tubs from the galley were requisitioned. At last the load sufficed, without the brake giving way. We now laid according to the statement of the measurements without "slack", i. e. without using more cable than exactly answered to the length of the sea-bottom. The cable was always pretty near the breaking point. as was proved by the fact that frequently one of the thick sheathing wires snapped, whereby the cable ran considerable risk. But by the adoption of prompt measures a fracture of the cable was averted, and when the sun set, and the cable-end in the ship was almost reached, my dynamometer luckily indicated shallow water, and we were at the goal.

The joy was general and intense, and even $\mathrm{Mr}$. Liddell congratulated me on the success achieved.

This was the first cable which was successfully laid in deep water, i. e. at a depth of more than 1000 fathoms. The laying of such heavy cables with many conductors has since been abandoned for long cable lines in deep water, because the difficulty of laying is too great, and because adjacent conducting wires interfere with one another by induction. This cable- 
laying was for me therefore all the more instructive, and certainly also the more exciting and straining.

The cable must pass out of the ship's hold, in which it is carefully coiled round a cone, over the brake-wheel and under the roller of the dynamometer, day and night without any stoppage, which is always dangerous in deep water. Every stoppage is a source. of great danger, since the progress of the ship cannot be checked with sufficient celerity. At the same time the brake-force must be carefully regulated in proportion to the depth of water, and to the velocity with which the ship is moving, otherwise the cable is either needlessly wasted, or it is strained at the bottom. Furthermore the electrical quality of the insulated core must be unceasingly tested, in order that the occurrence of a fault in the freshly immerged parts of the cable may be immediately detected. In such a case the laying must be at once suspended, and the last laid portion of the cable taken back again to repair the defect.

The continuous mental strain, and the consciousness that any error committed may occasion the loss of the whole cable, makes the laying of a deep-sea cable a very anxious, and for a length of time thoroughly exhausting affair for all concerned, and especially for the leader of the undertaking. Towards the end of the foregoing work, in which I would not allow myself a moment's rest and refreshment, I could only keep myself up by frequently taking strong black coffee, and required several days for recovering my strength. 
This cable-laying took me for the first time into southern regions. During the whole time we had splendid weather, and I enjoyed to the utmost the charms of the Mediterranean, with its deep blue water, its dazzling white wave-crests, and its refreshing air, of which we could never inhale enough, on the beautiful voyage from Genoa to Cagliari, and from there to Bona in Algeria. A surprising sight was afforded by the loftily situated solid castle of Cagliari, which was entirely engirdled by high-grown aloe bushes in full bloom. On the advice of the friendly captain of the corvette we did not remain in the harbour on account of the fever, but passed the night in the court of the castle ruins. This glorious night under the starry sky of Italy, high above the sea breaking upon the rocky coast in the moonshine, has never faded from my memory.

The electrical testings carried on during the laying showed that the insulation of all the conductors of the cable was imperfect, but on the completion of the line in the following year it satisfied in the case of three of them the conditions of the contract, which only required that the loss of current should not exceed a certain percentage. The fourth conductor contained a more serious fault, and the taking over of the cable was therefore refused. However it was possible by a suitable electrical manipulation - continuous treatment with an exclusively positive current - so far to lessen the defect, that the cable had to be taken over. 
The theory of cable-laying expounded on the above occasion I only made public in the year 1874 through the medium of a paper" entitled "Contributions to the theory of laying and testing submarine telegraph cables" submitted to the Berlin Academy of Sciences. I have preserved among my papers the copy of a letter, in which on my return I explained my theory to the before-mentioned Mr. Gordon, partner in the firm of Newall \& Co. I shall insert this letter here, as it forms the first detailed communication on my theory of cable-laying.

Berlin, 26 $6^{\text {th }}$ September 1857.

Dear Gordon,

Returning yesterday from my journey I found your letter of the 17 th.

First I will give you some particulars from the report made by engineer Viechelmann, who has to-day returned from Bona.

There is no doubt that wire No. 1 is injured, and that the injury lies in the neighbourhood of the African coast, and consists in the wire being in conducting connection with the water. It is not improbable that the defect exists where the shore-end is joined to the thinner cable. It has not been possible to determine the precise place, as it is uncertain how much resistance the connection has between the conductor and the water. The place can however lie no farther than four German miles (19 English) from the land, but is probably much nearer.

Through the amount of the charge and by determinations of the resistance in the metallic circuit according to the accompanying sketch (Figure 1) the situation of the fault may be more precisely determined, if you will make the attempt to take up the wire again from Bona. $m$ and $n$ are the two coils of a differential galvanometer, and $w$ a rheostat. By its means resistance is interposed, until the currents through the 
two coils $m$ and $n$ are of equal strength and the needle stands at zero. Then the fault $f$ lies midway, and the distance from the coast can be calculated.

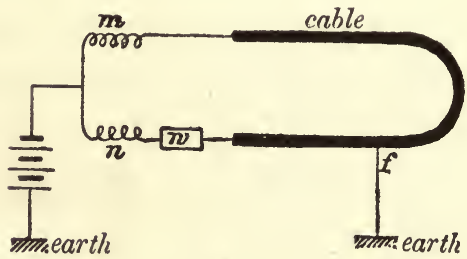

Fig. 1.

With well-insulated wires this can be done with perfect exactitude, with badly insulated ones, such as the Bona cable, at any rate approximately correctly. - Mr. Viechelmann has left the apparatus in the custom-house of Marseilles at your disposal. In the telegraph office there lies a letter from Viechelmann to Newall, in which the authority for its delivery is contained.

As regards the cable theory the following is my view.

If $A B$ (Figure 2) represents a flexible piece of cable, which is attached to the sky by a weightless wire $B C$, the cable will fall to the ground, without being able to deviate from the straight line in the suspended part, as at every point it falls with equal velocity. $m n, o p$ are of equal length.

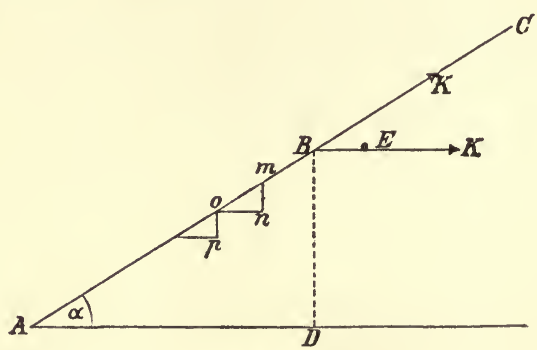

Fig. 2.

Every point falls with equal velocity, and the new connecting line $n p$ must again be a straight one. The active force pulling upon the wire $B C$ during the fall is $K=Q \cdot \sin \alpha$, 
if $Q$ is the weight of the suspended cable in the water, or the weight of a piece of cable $B D$, hanging vertically downwards, since $A B \cdot \sin \alpha=B D$.

If the force $K$ is less than is necessary for equilibrium, the cable slides back towards $A$, and the terminal velocity is reached, when the friction in the water is equal to the lacking. force. If on the contrary $K$ is greater than necessary, the cable acquires a velocity towards $B$, consequently the loss, i. e. the difference of the lengths $A B$ and $A D$ is picked up again, and the cable places itself in a straight line, thus without loss, on the ground. The angle $\alpha$ is accordingly quite independent of the amount of the force $K$. It simply indicates the proportion of the velocity of sinking to the progressive motion of the ship. For if the cable end $B$ instead of being attached to the weightless wire $B C$ is carried over a pulley, and the pulley moves with the ship from $B$ to $E$, whilst the cable falls the distance $m n$, and finally if the cable is kept back with the force $K$, there is no change at all in the conditions of equilibrium. If the brake, which detains the cable, is so applied that equilibrium is just attained, thus $K=Q \cdot \sin \alpha$, the cable has no axial velocity whatever; it falls perpendicularly, and there is the loss corresponding to the angle. If $K$ is greater, the cable is laid with little or no loss, if $K$ is smaller, the loss may be very great. The quicker in the latter case the motion of the ship, the longer does $A B$ become, the greater consequently the friction in the water and the smaller the loss. If on the other hand the force $K$ becomes greater than is necessary for equilibrium, the loss can easily be made up, and the cable then forms a catenary curve. If the transitions are rapid, the whole velocity, which the cable has acquired after applying the brake on disturbance of the equilibrium, acts in the direction $A B$, and tends to strain the cable. When one considers the great mass of the suspended cable, it is clear that these axial velocities of the cable may easily cause a fracture. The only safe guide is the proportion of the ship's velocity to the velocity of the cable. - Moreover the ocean currents must be taken into account, especially if they flow in various directions. If the current is everywhere equable, and extends to 
the bed of the sea, it only produces an additional expenditure of cable. With equilibrium of the force $K$ the cable settles down in the diagonal of the parellelopiped, instead of in the diagonal of the parallelogram, and the cable-length bears the same proportion to the distance traversed as the diagonal of the parallelopiped, whose sides are the ship's motion, the depth of water, and the simultaneous velocity of current, bears to the ship's motion. Very violent action on a tightly laid cable may however be exerted by variable currents, as the cable has then to resist the pressure of the water in the form of the catenary curve. Lastly the rising and falling, as well as the lateral movements of the ship, form forces of importance, threatening the fracture of the cable, unless the uncoiling apparatus is very light, or a compensation can be effected, whereby the cable may be lengthened or shortened behind the brake, so that no acceleration of the mass takes place. The mechanism which I propose for determining and regulating the tractive force exerted on the cable is easily calculated as under. (Figure 3.)

$$
\begin{aligned}
& K \cdot \sin \alpha=\frac{Q}{2} ; K=\frac{Q}{2 \sin \alpha} \\
& \sin \iota=\frac{h}{a b}=\frac{h}{\sqrt{\frac{e^{2}}{4}+h^{2}}} \\
& K=\frac{Q}{2 h} \cdot \sqrt{\frac{e^{2}}{4}+l^{2}} .
\end{aligned}
$$

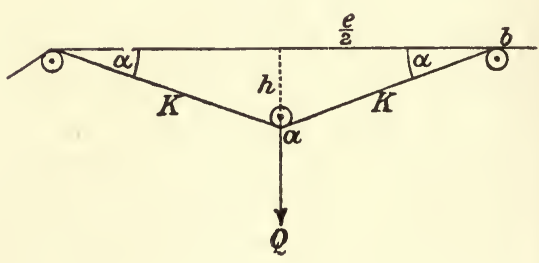

Fig. 3.

I have asked Löffler to calculate a table in accordance with this formula, of which however I am not yet in possession, as $\mathrm{L}$. is still in Cologne. $e$ was, as you state, 25 feet, i. e. 8.42 metres. The weight $Q$ was 160 kilograms, according to the statement of Newall's people, who weighed it. You seem in your approximative formula to have taken pounds instead, your values are therefore only about half those I have in my memory. The apparatus was constructed of wood the evening before the laying. Previously Mr. Liddel seemed not to be in favour of it, and I did not wish to obtrude myself after having 
made my proposal. In the first night the frame had become warped through the wet, and the place where the height was measured was about 2 feet lower than the other. A trustworthy measurement with an apparatus so crudely and hurriedly made and calculated is therefore out of the question.

That soon after the commencement of the laying much cable was wasted was clear. I therefore at once proposed a stronger loading of the brake, but could not have my way. Undoubtedly there were moments when the cable-line was almost straight, although in the ordinary course there was a depression of from 4 to 5 inches, and one such moment might have sufficed to break the cable. The brake was also too weak, and I was always in mortal terror lest, with the load of at least 5 hundredweight, which subsequently, when Newall left the matter in my hands, was applied, it should give way. As the cable would have been irrecoverably lost if the brake had given way, it certainly required a prodigious resolution to justify loading it in this manner. It is certain that we strained the cable too severely on the following day. We certainly laid it without any loss whatever, and perhaps already had some catenary curve force in the cable. This was owing to the circumstance that nobody knew how fast the vessel was going. Newall and Liddell thought we were not making 5 knots an hour, whereas in fact we had made $71 / 2$. As the cable ran off with the velocity of $7 \frac{1}{2}$ knots, I could only conclude that the waste was still too great for reaching shallow water, was obliged therefore to continue the loading. Thus there were moments, when the loading reached quite 6 tons, and the fluctuations were even greater.

That there was no regular log in the ship was a serious misfortune, and might easily have had for its consequence the loss of the cable. The greatest danger in cable-laying always consists in the snapping of single wires. That under the circumstances we came off as we did is a real marvel. I should not advise attempting a cable-laying in deep water without having previously subjected the wire in its whole length to a maximum strain, never to be exceeded in the actual laying. 
I have communicated a plan to Newall how this is very easily to be done. Then faulty weldings will be disclosed by rupture, and one may feel pretty safe afterwards. Furthermore a dynamometer of solid iron must be constructed with an accurate scale, and in such a way that with the maximum loading there still remains a deflection of at least one foot. It is better to make use of a well-made spring than a weight, so that the fluctuations of the apparatus may be as small as possible. It would also be very advisable to carry the wire behind the brake over two fixed and one moveable pulley, the latter being pulled down by a weight or still better by a very strong spiral spring. The up and down movements of the ship are thereby rendered innocuous.

28 th.

As Löffler has not yet returned, I can communicate to you nothing definite in regard to the calculated forces. You are quite right that the assumed forces are not justified by the depths alone. I believe we may go to half the depth for which a cable can support itself, with tolerable safety and to a third with great safety. Up to a fifth of the depth 5 to $10 \%$, to a third 10 to $15 \%$ slack may give sufficient safety, if the weather is favourable. At greater depths the loss must be considerably more. Newall's plan of retarding the sinking of the cable by shields is wrong in principle. The cable must sink as quickly as possible on account of the currents. With moderate depths it is more advantageous to take back the slack by somewhat greater loading of the brake. If the depth is greater than $1 / 3$ to $1 / 2$ of the minimum strength of the cable, the sliding back of the cable must be slackened as far as possible by disks attached at right angles to the cable. I believe these are best made of sheet-iron. A few large ones are far more effective than many small ones. The attachment can be effected in many ways. One must then proceed as quickly as possible, in order to keep the angle acute. - For the measurement of velocity I am now having made an electrical apparatus, which turns a large indicator by the side of the brake. The brake-wheel must indicate in the same way, so that at any moment the proportion of the velocity and of the exerted force 
may be known. The vessel must be well lighted, and the breaking of the wires must especially be kept in view. That the two wire-fractures did not entail the loss of the cable was a piece of luck such as seldom occurs. - Altogether I think you have all reason to be satisfied with the result. I do not consider it difficult to recover the cable-end. I likewise consider the repairing of the fourth injured wire feasible, if it is of importance to you. This granted, you have bought the experience and a right theory of laying cheap enough. If you choose to avail yourself of my proposals, you will in future be able to undertake a laying in perfect peace of mind and soon recoup yourself for past losses. With your new brake you should however make the experiment of severing the cable with a maximum strain. Mr. Newall told me before the arrival of the Elba that he could fracture the cable with his brake, but although on the day of laying we had lengthened the lever of the brake by a half, and had suspended at least twice as many weights as the lever and iron band could reasonably be supposed to stand, yet we had not reached such a force by a long way, apart from the great forces which were exerted during fluctuations and in the first mishap. With my own experiments I have unfortunately not succeeded much better than in England. I see however that one can certainly signal better in a metallic than in a semi-metallic circuit, and that it is impossible with long lines to signal through more than a single wire. The future belongs therefore to the metallic circuit, and the patent will be remunerative. I see further that our present construction of the induction telegraph acts remarkably well and accurately, and that several submarine translation stations may at pleasure be set up with absolute certainty, that thus e. g. there may be direct communication between England and India. Your apparatus for Malta-Corfu are despatched to-day. I am quite sure that they will do their work well. According to my present experience the inductors might have been smaller and therefore cheaper, but it is better to err on the safe side. Such fine and solid apparatus have never before been turned out in our workshops. The contacts. have given the greatest trouble. Platinum burns too quickly 
with strong primary currents, we were therefore obliged to use everywhere an alloy of gold and platinum, which with thick pieces has its difficulties. Perhaps you will get along with half the inductors on the Malta line (one coil). You will thereby effect a considerable saving, as the great quantity of silk-covered wire is expensive.

I beg you to let me know in good time when and where you wish to have the mechanician, and whether you think one enough. I think you should have plenty of intelligent assistants at your disposal, for any error may be very dangerous even with the best preparation.

I send this letter direct to Birkenhead, where I imagine you still to be, and where William intended to visit you; may I ask you to let William have a look at it?

Would it not be better do defer your Malta line to the winter, when you can more certainly reckon on calm weather? - October is said to be a very dangerous month there, and the atmosphere does not become quieter before December.

With sincere regards

W. Siemens.

The experience I acquired in the laying of the cable between Cagliari and Bona really convinced me, as expressed in the foregoing letter, that submarine cables of the right construction and carefully made could be laid at any depth of water, and then also promised long and certain service. I therefore took especial pains to overcome the existing difficulties. For that purpose it was necessary to establish a systematic supervision of the manufacture of the cable, in order to obtain the certainty that no defect existed in the whole cable stored in the ship's hold. This could only be effected by making the testing instruments 
sufficiently sensitive for measuring the insulating quality of the gutta-percha itself employed and indicating the same in figures.

When the insulation-resistance of the conducting wires coated with this gutta-percha had then in a similar manner been determined numerically they were faultlessly insulated, provided the measured result agreed with the calculated. If the resistance of the conductor of the complete cable was not greater, and the resistance of the insulator of the same not less, than that ascertained by calculation, the cable might be regarded as faultless.

It was not to be expected that such exact testings could be carried out by measuring currents. For determining the position of faults, for which I had as early as 1850 found and published the necessary formulae, the inexact current-measurements were also insufficient.

It was necessary therefore to have recourse to measurements of resistance, but for that there were still wanting good practical methods of measurement, and especially a fixed standard of resistance. Finally the knowledge of the physical properties of the jar wires, as I had termed the underground conductors on account of their property of acting as large Leyden jars, was still too undeveloped for planning long submarine lines without risk of failure.

I had been intently occupied with the study of these questions since 1850. My labours belonged to the time when the great investigator Faraday astonished the scientific world with his fundamental discoveries. 
In Germany however many of the views of Faraday, particularly those of electrical distribution by molecular induction, being incompatible with prevailing theories, obtained but little credence. This induced me to study, without regard to existing theories, the question of electro-static induction, which was of extreme importance for telegraphy according to my earlier experience. I finally obtained a complete confirmation of the views of Faraday, for the correctness of which I was fortunate enough to find new proofs. Unhappily being oftentimes interrupted in my labours by my strenuous technical activity I could not conclude my experiments before the spring of 1857, when I summarised their results in a paper published in Poggendorff's Annalen "On electrostatic induction and the retardation of the eurrent in jar wires".

It became clear to me from these experiments, that only by employing short intermittent currents was there any prospect of corresponding quickly on longer cable-lines. In a paper "The induction writing-telegraph of Siemens and Halske" published in 1857 I described the mechanical expedients for accomplishing this task. They consisted essentially of a magnetically polarized relay, which was so constructed that its armature, when moved by a short impulse of current to the contact, remained attached to this, until a short current in the opposite direction carried it back to the insulated stop. The short intermittent currents were generated in the secondary coil of an inductor by the telegraphic currents being sent through the primary coils of the same. 
When in the same year - 1857 - Messis. Newall \& Co. laid a cable-line from Cagliari to Malta and Corfu, I furnished the stations of this line with such induction writing telegraphs. A translation station was erected on the island of Malta, which made it possible to correspond by the thin cable direct between Cagliari and Corfu with satisfactory speed. In order to secure the good insulation of this as well as of other lines, which were to be laid in the eastern part of the Mediterranean, my firm undertook the electrical testing of the insulated conductors in the cable-works of Messrs. Newall \& Co. at Birkenhead. A talented young man, Mr. F. Jenkin, who afterwards made a name as an electrician, was assigned me as assistant.

The cable-line through the Red Sea and Indian Ocean from Suez to Kurrachee in India, the execution of which had been intrusted to the firm of Newall \& Co., brought me a very interesting task. My firm undertook for the latter the electrical supervision of the laying of this cable, as well as the furnishing and setting up of the necessary instruments. The most important of the cable-lines laid up to that time, that from Sardinia to Corfu, about 700 nautical miles long, hardly afforded a standard for the construction and working of a line of 3500 nautical miles in length, such as the proposed cable-line to India. According to previous experience it was possible by intermittent currents to work lines 700 nautical miles in length with safety and sufficient power.

There were accordingly four or five intermediate 
stations to be set up between Suez and Kurrachee, which had to be provided with automatic translation, so as to be able to work without troublesome and embarrassing imanual transferring of signals. The fitting up of these translation stations was however attended with peculiar difficulties in the case of long submarine lines, as the charge left in the cable produced disturbances, when as on the Corfu line it was undesirable to telegraph with secondary currents. There were practical reasons moreover against the latter mode of operating, which especially consisted in the greater complexity of the whole arrangement. I accordingly constructed a new system of signalling apparatus, which was afterwards designated the "Red Sea system". In this, not intermitting currents produced by induction, but battery currents of varying direction, were employed. The effect of this was that after every word an interruption of the second demagnetising battery, and a discharge of the cable, must occur, before the latter was again connected with the relay. For this purpose special simple contrivances were made use of, which were described at length in the account of the system, which I published in 1859 in the German-Austrian Telegraphic Journal, with the title "Apparatus for working long submarine lines". In the first part of the line between Suez and Aden, which was laid in the spring of 1859 , such translation stations were established at Cosseir and Suakim. They acted in a very reliable and satisfactory manner, so that it was possible to correspond with the Morse key provided 
First employment of the CONDENSer in Cable telegraphy. 181

with discharging contact as quickly as on land lines, whilst by excluding translation stations it was only possible to make oneself understood very slowly on the line of 1400 nautical miles in length.

During my stay in Aden, however, I succeeded by a peculiar expedient in communicating quickly and certainly by the direct line also, and in rendering the intermediate translation stations superfluous. Through the study of the electric properties of underground conductors it had become clear to me that all the secondary currents, which confuse the telegraph signals, could best be avoided, if definite amounts of positive and negative electricity in proportion to the capacity of the cable were suddenly sent to the delivering end of the cable, and likewise at the receiving station only definite quantities of electricity were allowed to leave the cable. At first I thought to be able to attain this by the intercalation of a polarizing battery, possessing so large a number of elements and so small a surface of electrodes that the quantity of electricity necessary for reversing the battery just sufficed for moving the relay-bar. I had brought with ine such a polarizing battery of 150 platinum elements, but found that the resistance of the battery did almost as much harm as the polarizing action did good. The fortunate circumstance however came to my assistance that the remnant of the cable of 150 nautical miles, or so, had been submerged from Aden, to be subsequently utilized for the further extension of the line. This was an electric condenser, which could not but accomplish, 
without the injurious resistance of the polarizing battery, what I had expected of the latter. I therefore had the more remote end of the cable insulated, when the laying was completed, and used the cable as an earth connection. The result was brilliant beyond expectation. The Morse writing could now not only be received direct from Suez without any difficulty, but to my surprise could also be sent there without lessening the speed of the signalling.

This was the first employment of the condenser in submarine telegraphy, without which it would not have been possible to communicate on the long Atlantic lines with the speed and certainty now permitted by 'Thomson's mirror galvanometers. Instead of insulated lengths of cable, paper or mica condensers are now made use of, which we did not possess at that time. As regards the laying itself, I had introduced a systematic method for the control of the electric properties of the cable, which excluded all uncertainties and misunderstandings. A clock was set up at the starting point, which automatically insulated the end of the cable at definite intervals of time, then connected it with the earth, and finally with the telegraphic apparatus. The ship could therefore carry out all the measurements without the co-operation of the land station, and the like held good of the land station, which continuously telegraphed its measuring results to the vessel, so that the latter possessed the requisite data for calculating according to my formulae the situation of any suddenly occurring fault. This supervising 
method turned out to be extremely necessary, for the notoriously high temperature of the Red Sea softened the gutta-percha and thereby produced numerous faults. In spite of all the care that had been taken for their removal, it appeared on arriving in Aden that a fortunately considerable, and therefore easily discoverable - defect existed in the cable, which rendered communication with the preceding station Suakim impossible. The determination of the fault from Aden yielded the result that the defect was somewhere in the vicinity, i. e. in the Straits of Bab-el-Mandeb. Although Mr. Newall and his engineers had not much confidence in my determination of the position of the fault, yet the cable was fished up and cut close behind the place I had indicated, whereupon to the general surprise and joy it appeared that the part of the cable connected with Suakim was sound. The fault was situated almost exactly at the calculated place, and was removed after inserting a short piece of new cable.

Through this successful incident the "scientific humbug" had come all at once to honour. Success was rendered possible by my having entirely substituted resistance measurements for current measurements. A fixed standard of the resistance to electrical conductions did not then exist. Jacobi had tried indeed to introduce a purely empirical standard as general measure of resistance by sending to scientists and mechanicians pieces of copper wire of equal resistance, recommending them to take this resistance generally as unit. But it soon appeared that the resistances varied, and repeated 
copying magnified the variations by a large percentage. My firm had up to that time taken the resistance of a German mile $\left(4^{3}{ }_{t}\right.$ miles English) of copper wire of 1 millimetre diameter as unit, and produced graduated scales of resistance on the basis of this unit. It appeared however that the copper itself with the utmost possible purity had essentially different specific resistance, and changed its resistance in the course of time. To adopt the absolute unit of Weber as fundamental standard was rendered impossible by the then state of electrical measuring, which at the time made an agreement of the various productions of this unit unattainable. Under these circumstances I resolved to make pure mercury the basis of a reproducible standard of resistance, and proposed to take the resistance of a mercurial prism of 1 square millimetre in cross section and 1 metre in length at the freezing point of water as the unit of resistance. I shall return to this standard of resistance in the description of my papers on this subject, and shall only remark here that the scales of resistance with the mercury unit, regulated according to the weight system, prepared by my firm, proved extremely useful in laying the cable from Suez to Aden, and for the first time made reliable determinations of faults possible.

The cable-laying in the Red Sea was also rich in interesting personal experiences for myself. The very day after embarking at Trieste in the beginning of April, I was so fortunate as to witness a splendid zodiacal light in the evening sky. Scientists contended 
then, and still contend, concerning the cause of this phenomenon. I believe those to be in the right, who see in the zodiacal light a proof, that the air charged with aqueous vapour, rising in the equatorial zone with increased velocity, forms a high ring above this zone, which is further enhanced by the effect of centrifugal force. The appearance answered to the pictures one sees in manuals of physics, and lasted about an hour before it became quite extinct.

After an agreeable, calm passage we arrived in splendid weather at Corfu, where we stopped several hours, and had time to make acquaintance with the interesting town and its splendid environment. At that time the Ionian islands belonged to England. When after a number of years I again visited Corfu it had meanwhile passed into the hands of the Greeks, and the town appeared to me considerably decayed and poverty-stricken compared with its former appearance.

In the finest weather we sailed through the Adriatic and Mediterranean, so rich in historical associations, disembarked at Alexandria and travelled by the just opened railway to Cairo, where we stopped a few days to give the ship Agamemnon, laden with the cable, and which made the journey round the Cape of Good Hope, the necessary time for arriving in Suez. I used this opportunity for an inspection of the town, which interested me and my engineers in the highest degree by its rich historical memorials and as the point of junction of the civilizations of Europe and Asia. When on the 14 th of April we visited the pyramid of Cheops 
we had the good fortune to observe on its apex an interesting physical phenomenon, of which I subsequently gave an account in Poggendorff's Annalen under the title, "Description of unusually strong electrical phenomena on the Cheops Pyramid near Cairo during the blowing of the Chamsin."

During our donkey ride from Cairo to the pyramid there arose an unusually cold desert wind, which was accompanied by a peculiar ruddy colour of the horizon. During our ascent or rather our transport by the Arabs, who always encamp by the Gizeh pyramids, and do not allow the office to be taken from them of carrying or rather throwing the visitors up the steps, each a yard high, the wind assumed a tempest-like force, so that it was to a certain extent difficult to keep oneself upright on the flattened apex of the pyramid. The raised desert dust had now become so thick that it appeared like a white mist, and altogether obscured the view of the ground. It gradually rose higher and higher, and after some time wrapped even the summit on which I with my ten engineers was standing. Then a remarkable hissing noise was heard, which could not have been caused by the wind itself. One of the Arabs called my attention to the fact that by raising his outstretched finger above his head a sharp singing sound arose, which ceased as soon as he lowered his hand. I found this confirmed when I myself raised a finger above my head; at the same time I noticed a prickling sensation in my finger. That we had to do with an electrical phenomenon appeared from the 
circumstance that a slight electrical shock was felt when one tried to drink out of a wine bottle. $B y^{\circ}$ wrapping a piece of damp paper round it, I transformed such a filled bottle, having a metallically coated neck, into a Leyden jar, which was strongly charged when one held it high above one's head. It was then possible to obtain loud cracking sparks. of about 1 centimetre range. This established in an unequivocal manner the electrical properties of the desert wind which had been already before observed by travellers.

In the further course of our experiments I had occasion to prove that electricity can also be serviceable as an effective defensive weapon. The Arabs had at once observed with manifest distrust the flashes darting from our wine bottles. They then held a brief council, and at a signal every one of my companions was laid hold of, to be forcibly transported down again, by the three men who had brought him there. I was standing just on the highest point of the pyramid, a large stone cube in the centre of the flattened summit, when the sheik of the tribe approached, and communicated to me through our interpreter that the tribe had resolved we should immediately leave the pyramid. On being asked the reason, he replied that we manifestly practised magic, and that might injure the source of their livelihood, the pyramid.

When I refused to comply with his request, he made a dash at my left hand, whilst I held the right with the well-coated bottle - in a manifestly conjuring attitude - high above my head. I had waited 
for this moment and now lowered the neck of the bottle slowly towards his nose. When I touched it I myself felt a strong concussion, to judge from which the sheik must have received a violent shock. He fell speechless to the ground, and several seconds elapsed, making me somewhat anxious, before with a sudden cry he raised himself, and sprang howling down the steps of the pyramid with giant leaps. When the Arabs perceived this, and heard the sheik's continuous cry of "magic", they one and all abandoned their prey and plunged after him. In a few minutes the battle was over, and we were absolute masters of the pyramid. Anyhow Napoleon had not such an easy "victory at the foot of the pyramids" as I had at their summit!

As the blowing of the Chamsin soon ceased, and the sun again brightly illuminated the imperilled pyramid, the Arabs recovered from their terror, and clambered up again so as not to lose the expected "backsheesh". Even at our peaceful leave-taking however they evidently still regarded us with suspicion on account of our magical powers.

Nor were there wanting some small adventures by sea during this cable-laying. The weather was thoroughly calm and fine, as is always the case in the Red Sea, where a rain-fall is a great rarity; only the enervating heat was inconvenient. My travelling thermometer indicated by day nearly always $100^{\circ}$ and by night $102^{\circ}$ Fahr., a temperature, which with our northern strength is indeed borne tolerably long without difficulty, but which in the long run becomes extremely 
troublesome. By day one lives in a perpetual conflict with the sun, from whose rays head and back must be carefully protected. By night the hoped for cooling is entirely wanting. The splendour of the starry southern heavens with the truly Egyptian darkness of the nights is indeed imposing, but it does not make up for the desired refreshing breeze.

One night, as I was in my test-room supervising the insulation of the cable between Cosseir and Suakim, I suddenly heard loud shouting and violent commotion on board. The man at the ship's head, entrusted with the continuous soundings, had fallen overboard. As the whole deck was well lighted with gas, many of the people busy there could see the man calling lustily for help in the water and throw him life-belts, kept ready everywhere on board. The vessel was stopped and boats put out, which disappeared for an uncomfortably long time in the darkness of the night. At last they returned triumphant. The man had kept himself afloat by swimming, and had been lucky enough not to be seized by any of the numerous sharks, which disport themselves in the Red Sea, and are said to have an especial appetite for white people, whilst they rarely molest the black. He was trembling violently when brought on board, and had his knife still open in his hand. Questioned as to what had befallen him, he related that he had been surrounded by a number of sharks, but luckily had been able to draw his knife, and defend himself till the boats arrived. We all felt a cold shiver at the vivid description of his perils 
and combats. The boatswain just then stepped into the ring, which had been formed round the man, and announced to the captain that some of the life-belts, which had been thrown to the unfortunate man, had been recovered, and that several of them curiously showed signs of having been pierced with a knife. The man in his terror had taken the white rings for sharks' bellies - the shark, as is well known, turning on his back when preparing to snap.

The shark plays an important part in the sailor's life in the torrid zone, as he spoils the mariner's refreshing bath. The sailor therefore passionately hates him and tortures the animal with glee, if he succeeds in getting hold of one. I was witness when two powerful sharks, at least twelve feet long, were caught on a small flesh-baited anchor, and brought on board. It was rather dangerous to approach them. They had immense strength and so tough a life, that even after having been disembowelled they still lashed about with their tails.

When we lay at anchor in the harbour of Suakim it was strictly forbidden to bathe, as very many sharks were disporting themselves in the neighbourhood. One evening after sunset, which is there quickly succeeded by perfect darkness, we were sitting as usual at dinner on deck, when suddenly "shark" was called by several voices, and at the same time the cry of a man for help resounded. The boats were lowered, and in the light streaming from the ship something could be clearly discerned moving in the water, which was taken 
for a shark. Several ran for their revolvers, which lay always ready, as it was a common sport to shoot at empty soda water bottles thrown into the water during the progress of the vessel. Luckily before the commencement of the cannonade it became apparent that the supposed shark was a sailor who, contrary to the prohibition, was taking a bath, and had been alarmed by his comrades' cry of "shark!"

Arrived at Suakim we soon received a visit from the highest officials, the Turkish pasha and the governor of the place. They were both extremely dignified figures, who moved with oriental gravity, and carefully avoided all appearance of being astonished at anything. A carpet was spread for them, and tchibouk and coffee served. They smoked and drank with dignity, without regarding us, who were standing round them. My friend William Meyer, who accompanied the expedition, said "Look Werner, what a splendid fellow that is with the fine white beard; he might be exhibited in Berlin for money!" To our astonishment the individual in question turned slowly towards us and said in the purest Berlin dialect: "Oh, you speak German?" On our replying that we were Germans, but were surprised that he could speak German, he answered: "I 'm also from Berlin. Call upon me!" Then he turned his head back in a dignified manner, and took no further notice of us. Meyer called upon him next day, and made the acquaintance of a thoroughly sociable man when not in Turkish company. He had left Berlin as journeyman tailor and 
gone out into the world fifty years ago, was making for India when he was wrecked in the Red Sea off Suakim, stayed there, became a Mohammedan and finally chief of the town. At the same time he had become a rich man. He showed my friend all his possessions, he was only unwilling in spite of all requests to show him his harem, and at last earnestly forbade him to speak about his wives.

When we had finished our business in Aden I wished to return with Meyer to Europe as quickly as possible by the next steamer of the Peninsular and Oriental Company, the Alma. Messrs. Newall and Gordon contemplated doing the same. When the steamer arrived it was however quite full, and they refused to take us. Only through an order of the Governor of Aden, procured by Mr. Newall, were we able to carry out our purpose, though but as deck passengers, no cabins being vacant. We had no objection to this, as during our several months' stay on the Red Sea we had always slept in our clothes on deck, as the heat below was insufferable.

On board we found arrangements of a really luxurious character, and an elegant social life almost to be styled epicurean, which contrasted strongly with our recent existence. Ladies and gentlemen changed often in the day their elegant toilets, and two bands of music took it in turns to lessen the tedium of the voyage. We appeared very much out of place in our ragged garments in this fine circle, and the glances of the ladies that fell upon us betrayed indeed 
intense astonishment at such an unseemly addition to the ship's company. Nevertheless we were presented by the first lieutenant to the highest in rank of the company, the English Ambassador to China, who had just happily succeeded in bringing on the Anglo-French war with China. He graciously gave us an audience, and exchanged a few words with each of us in his mother tongue, being rather proud of his own extensive linguistic acquirements and delighting to display them. At the approach of night each sought his camping place on deck, but our rest was long disturbed by the ladies, who could not make up their minds to return to the stifling cabins.

We had slept only a few hours, when we were rudely awakened from our dreans. A violent shock caused the ship to tremble, two others followed still more violent, and when we had sprung up in alarm we felt the ship heeling over. I had luckily not taken off my boots, only laid aside hat and spectacles. When I looked round for these, I perceived my hat already on the way to the sinking ship's side, and involuntarily followed it in the same direction. Wild, terrified, ear-piercing shrieks resounded on all sides, then a general clatter, as everything on deck was taking its course to the deep. Everybody instinctively made for the higher part of the ship, most were able to reach it. I came off worse, having lost time in my search for hat and spectacles. Already the water streamed over the ship's side, and warned me to think of my own safety. The deck had in a few seconds assumed so oblique a po- 
sition that it was no longer possible to clamber up it. But necessity gives giant strength. Piling up chairs and tables I managed to reach a rope, visible in the bright moonshine, which hung down from the elevated part of the ship, and climb up by its assistance.

Above I found almost the whole ship's company already assembled, and awaiting with admirable composure the development of the drama. Then faint cries of women for help broke the stillness of the night, and some one called out that there were still many ladies in the already half-flooded cabins. Everybody was ready to assist in rescuing them, but this was very difficult to accomplish, as the smooth deck, lying already at an angle of more than $30^{\circ}$, offered no longer a foot-hold. My rope now did good service. A seaman, familiar with the ship's structure, let himself down to the entrance of the cabin, and fastened a lady to it, whom we then pulled up. That proceeded however too slowly, for a large number still waited to be rescued. Accordingly with the help of further ropes a living chain was soon formed, by which the poor trembling ladies, for the most part surprised in their beds by the water streaming through the opened cabin windows, were lifted up from hand to hand. If an impediment occurred anywhere the word "stop!" was given, and then everybody had to sustain his burden until the furthering process could be continued. At one of these pauses I beheld by the moonshine in the dripping lady, anxiously 
clinging to me, the proud young creole, whom we had admired at a modest distance, a few hours before, surrounded by a crowd of adorers which her beauty had attracted.

The rapid sinking of the ship, after striking upon a concealed coral rock, was explained by the circumstance already mentioned that the cabin windows had all been open, and the water therefore found unimpeded access into the hold. The vessel soon lay entirely on her side, and the great question, on which now the life or death of every living being on it depended, was whether it would assume a position of rest, or capsize, and hurl us one and all into the deep.

I erected for myself a little observatory, with the help of which I could note the further inclination of the ship by the position of a particularly brilliant star, and proclaimed from minute to minute the result of my observations. These communications were awaited with great anxiety. The cry "stand-still!" was greeted with short joyful murmurs, that of "sunk further!" answered by various doleful exclamations. At last no further sinking was observable, and the paralysing fear of death gave place to energetic efforts for effecting our safety.

By the light of the moon and the glittering starry sky we could distinctly perceive that we had run upon a large rock, rising at one point tolerably high above the water, and now only a few hundred yards from us. The life-boats fastened on the lee-side could be lowered without much difficulty, and then in 
conformity with traditional English sea-faring practice the women and children were first put on shore. That was in truth extremely unpractical, as on the land the poor creatures were in a desperately helpless condition, but the principle had to be rigorously observed.

When at day-break the turn of William Meyer and myself came, we found the ladies almost without exception in an extremely lamentable plight, as they were very sparingly clad, and for the most part shoeless. The rock, perhaps never before trodden by human foot, was everywhere covered by jagged coral, which drew blood from the unprotected feet. Here help was most needed. I belonged to the lucky ones who possessed boots, and had also saved my pocket knife. I accordingly returned with the next boat to the wreck, and fished out a thick mat of linoleum and another of finer material, with which I then opened a sandal workshop on shore. My friend, who had not been so fortunate as to have saved his boots, was the first to receive a pair of sandals, and then in gratitude undertook to fit the ladies crouching motionless on the ground with similar articles. He still remembered years after with delight the grateful glances from beautiful eyes, which this Samaritan service procured him.

But what next? On Whitsunday morning about five hundred persons were sitting on a bare coral rock a couple of acres or so in extent, and about eight leagues out of the usual ships' course. We had in the fine calm night, in which probably helmsman and look-out had fallen quietly to sleep, run on the notorious 
coral bank lying to the south of the Harnish islands, and which is given a wide berth by all ships. We could the less depend on a chance rescue, as the total absence of drinking water rendered long waiting for help impossible. The vessel indeed had not sunk entirely, and we could save provisions of all kinds in sufficient quantity, but the water-tank had become filled with sea-water, and the distilling apparatus, which was used for producing the needful fresh water, could not be lifted out of its place. The water still found in the cabins formed therefore our sole supply, on whose sparing use it depended how long we should be able to continue the struggle for existence.

But yet another serious danger threatened us. The crews of the fine large steamers of the Peninsular and Oriental Company, which then worked the service between Suez and India, consisted almost wholly of natives, as Europeans are not able to stand the climate of the Red Sea for any length of time. Among the 150 persons or thereabouts, who formed the Alma's crew, there were thus, with the exception of the ship's officers, only three or four Europeans. The captain was ill, and is said to have died from the effects of the excitement soon after the shipwreck. The officers had by their bad management of the vessel lost the men's respect, and could no longer maintain discipline among them. The latter began therefore to mutiny, refused obedience, broke open the travellers' trunks, and behaved rudely to the ladies. In these straits a sort of government came spontaneously into 
existence. The most active of the younger men, including a number of English officers on their way home from India, took possession of the old muskets with bayonets, which were rather for ornament than for real use in the vessel, and proclaimed martial law. A recalcitrant drunken sailor was knocked down, and on the summit of the rocky eminence a gallows was erected as a sign of our authority. Thither, too, all the recovered provisions were taken, and a guard-tent was set up, before which a sentinel patrolled. This had a calming effect and reduced the crew to submission.

It was above all things necessary to obtain protection from the sun, which at this time of year shone vertically down on the island at mid-day. Accordingly a certain number began busily to occupy themselves in erecting tents with the help of sails and yards. Further a kitchen was contrived, and the provisions, especially the water and the stock of beer and wine, were stored safely. In these operations Mr. Gisborne, the leading engineer of the cable-laying, was especially prominent, and exercised a sort of dictatorship on the island. Mr. Newall had at break of day immediately gone with one of the three boats, which were at our disposal, to Mokka, the nearest place on the Arabian coast, to seek assistance. He did not find any there however - perhaps because the recent bombardment of Djedda by the English had caused a very unfavourable feeling towards Europeans - and therefore proceeded further towards the Straits of Bab-el-Mandeb in the hope of falling in with a vessel. 
This voyage in a frail open boat was a bold enterprise, but our only hope depended on it. And in reality it succeeded, thanks to a splendid telescope, which I had had made for my journey by Steinheil in Munich.

For when the English man-of-war, which had left Aden a few days after us to visit the intermediate stations, and take off our engineers, had passed in the early morning the Straits of Bab-el-Mandeb, our engineer Dr. Esselbach was standing on deck, searching with my telescope the vast unbroken expanse. He descried a white point, which he took to be the sail of a European boat, as the natives only use brown sails. He called the attention of the ship's officers, and lastly of the captain himself, to it, who with my telescope convinced himself of the correctness of the observation, and at once directed his course to the white point. To the great surprise of everybody this soon developed into the boat of the passenger steamer well known to the seamen, and already in the far distance Mr. Newall was recognised by his striking long white beard.

Meanwhile the life on the coral rock had rolled on as might have been expected. From 9 o'clock in the morning to 4 o'clock in the afternoon we were obliged to lie quietly under the roofs of our tents, to enable us the better to resist the glare of the sun and not to excite too great a craving for drink. Then the cooking began, and we dined as well as we could, each of us getting on the first days a, small bottle of pale ale, as the water was reserved for the women and 
children. Wine, which was also to be had, no one could stand; it heated the blood to such a degree that those who tried to drink it got ill. The first two days all went passably well, but then great lassitude and despondency began to set in. Faithful old servants refused to perform small services, even though gold pieces were offered them. Even the sheep and dogs, which had been brought to land, lost all vitality. They pushed with resistless force under the tent-covers, and chose rather to be killed than subjected to the pitiless rays of the sun. The pigs alone excelled even the human beings in endurance; they kept incessantly exploring the island, until they dropt dead in their struggle for existence.

On the third day a small number of us, who still possessed sufficient force and self-control to perform work when the sun was low, succeeded in breaking through the outer wall of the ship and obtaining access to the ice-room. Certainly there was no longer any ice to be found there, but a moderate quantity still of cold water. This was likewise reserved for the numerous women and children, but every one who had assisted in the work received as reward a glass of cold fresh water. Many years after I have often gratefully remembered that refreshing draught when tormented and parched with thirst.

When the fourth day passed without prospect of release, dull despair took possession of even the stoutest hearted. A steamship, whose smoke we descried in the far distance had gone its way without 
discovering us. On the following morning the cry was again raised "steamer in sight!" but the cry this time only awakened feeble hope. Still the smoke came nearer, and the already slumbering vital spirits awoke anew. The ship now approached, now moved off again; hope began to spring up that it was seeking us. Then at last it seemed to perceive our signals, it steered its course straight for the island. No more doubting! Rescue was at hand, and its certainty made the almost dead alive again. We recognised our companion ship in the cable-laying and Newall, our saviour, on board.

The scenes, that were now enacted, are never to be forgotten. On the ship all was astir for effecting the landing. Nobody appeared to notice the many-hundredvoiced jubilation that greeted the ship's crew. The anchor rattled down, and the boats shot into the water. They brought casks full of water, and flat wooden vessels, which were then placed on land and filled by stout sailors hands. Mr. Newall had informed them that we were in want of water, and their first thought was to quench our thirst. Every one made a rush for the large wooden vessels and tried with hollow hand to scoop up the water. But that was a slow affair, and other's kept pressing forward. Accordingly the head was simply lowered and the delicious fluid swallowed in greedy draughts. The beasts too had scented the water and pressed forward with irresistible energy, although they had been lying for whole days as dead under the tentcovers. A huge wether pushed everybody aside, and 
plunged its own head into the vessel between that of a fair blonde and a negro, without the latter being at all disturbed. Pictures, assuredly never to be forgotten by those who gazed upon them.

As the number of about five hundred passengers and ship-folk was too large to be transported by the small man-of-war, the captain determined to leave the crew on the island under a guard of sailors from the war-ship, to be kept under strict discipline on account of their mutinous behaviour, but to take all the passengers on board and convey them to Aden. So we arrived, packed in fearfully close quarters on the deck of the little ship, again in Aden, where the telegraphic news of our arrival in Suez had already been anxiously awaited. By order of the governor of Aden the next homeward-bound passenger steamer had to take up almost the entire number of the shipwrecked, in spite of its being already overcrowded. But we gladly bore the inconveniences of this passage, and of the further one from Alexandria to Marseilles, and thanked God that we had not met with a tragic end on the lone coral rocks of the Harnish Islands.

Neither in Cairo nor in Alexandria had we leisure to improve our very defective external appearance. Nearly all had lost their whole baggage in the shipwreck, and most of us were without funds. Not before Paris, whither we travelled without stopping, was an opportunity afforded for a fresh outfit. We were all obliged to travel by way of Marseilles, as the harbour of Trieste was blockaded by the French, and the 
journey through Italy was impossible on account of the war in Lombardy. The news of the declaration of war by France and of the death of Alexander von Humboldt I had received in the Red Sea during the cable-laying. The subsequent great political events had also been communicated to us through the cable, so that we had remained well-informed of the events of the world.

For the rest Meyer and I narrowly escaped being: left behind in Malta. The captain of the French passenger steamer emphatically declared that he could take no passengers to Marseilles without passports, that we must therefore provide ourselves with passports in Malta, if we had lost our own in the shipwreck. When the captain presented us to the respective consuls as shipwrecked persons handed over to him in Alexandria, all the rest received consular passports without any difficulty; the Prussian consul alone, a commercial man who had settled there and been entrusted with this office, declared that he possessed no authorization, as we could produce no regular evidence of identity. Only after some stormy scenes did he give in, and we were able to reach the ship just before its departure.

The Indian line was extended in the following year from Aden to Kurrachee, William Meyer superintending the electrical arrangements. Unfortunately the line did not long remain in a serviceable condition. Defects of insulation, which impeded correspondence, showed themselves already in the Red Sea 
cable in the course of the extension of the line to India. Our electricians attempted repairs indeed, whereby all the more serious faults were removed, but new ones constantly made their appearance, which already in the following year rendered the whole line unserviceable, since the cable in the Red Sea was held fast at the bottom by coral formations and therefore could not be raised and repaired. The reason of this unfortunate failure was mainly owing to the circumstance that the contractors had laid the cable, not in deep water in the middle of the sea, but near the Nubian coast, in the proximity of the intermediate stations, in shallow water, where the formation of coral proceeds very rapidly at the sea-bottom. People had not yet come to see that with submarine cables not cheapness but excellence is in the first place to be aimed at. It was apt to be forgotten that a single defect, if it cannot be repaired, spoils the whole cable, and that from any defect of insulation, however small a greater one is sure to arise in course of time. Almost all the submarine cables laid in early days by the English - both those in the Channel, in the Mediterranean and Red Sea, and also the first Atlantic cable, which was laid in the summer of 1858 by the engineer Whitehouse after an unsuccessful attempt in the preceding year - came to grief, because in the construction and fittings, as well as in the testings and laying, correct principles had not been followed.

It was the perception of this fact that led the English Government in the year 1859 to entrust the 
control of the preparation and the testing of cables, which it contemplated laying, to our London firm. In these testings for the first time a consistent rational system was adopted, which afforded assurance that the completed cable was faultless, if the conductivity of the copper conductor and the resistance of the insulating covering entirely corresponded to the specific resistances of the materials employed. The result was that the insulation of these new cables was more than ten times as great as had been the case in previous submarine cables.

My brother William and I communicated in July 1860 to the British Association the substance of the report delivered to the English Government on the performance of these testings and the methods and formulae employed in a paper read by William, entitled "Outline of the principles and practice involved in testing the electrical conditions of submarine cables", and in this way we made our experiences public property.

Since then no cables with defective insulation have been laid, and their durability has proved satisfactory wherever mischief has not been wrought by local causes or external violence. In cables laid in shallow water - both in the Mediterranean and also in the Black Sea - such a destructive agency presented itself in the shape of a small beetle belonging to a group particularly dangerous to wooden ships (Xylophaga). In the cables without iron sheathing laid by the firm of Newall \& Co. in the eastern part of the Medi- 
terranean a large part of the hemp covering the conductor insulated by gutta-percha was eaten away before the end of the year. Moreover the little animals had frequently attacked the gutta-percha itself, and there were numerous places where they had bored right through to the copper, and thereby entirely destroyed the insulation. Even an iron sheathing does not completely prevent destruction by the wood-worm of a cable laid in shallow water, as places at which an outer wire has been fractured afford it access, and as the young brood can make their way through the interstices of the protecting wires and then grow to a dangerous size within the protecting covering. To obviate this danger brother William had constructed a special cable for shallow water, in which strands of the best hemp twisted round the conductors, insulated by gutta-percha or caoutchouc, gave the cable the necessary support, whilst a layer of strips of copper-sheathing placed over one another in the manner of scales was destined to protect the core of the cable from the wood-worm. Our London firm, which meanwhile had set up a good-sized mechanical workshop and a cable factory of its own at Charlton near Woolwich, received an order for such a cable from the French government for a line between Cartagena and Oran. The then director-general of the French telegraphs, M. de Vougie, had already expended much money in attempts to lay a cable from the French to the Algerian coast, without having obtained a satisfactory telegraphic communication. He now wished to 
effect this in the cheapest way by a very light cable via Spain, and entrusted us with the preparation and laying of a copper-sheathed cable between Cartagena and Oran.

The French Government had stipulated for the procuring of the steamer as well as for its manning and officering by members of the imperial marine. 'The director-general, who was well known to me, as we had both served on the jury of the Paris Exhibition of 1855 , intended to be present at the laying. William and I desired jointly to supervise the proceedings, and we accordingly met in December 1863 in Madrid. I travelled from Moscow, where I had happened to be detained, via St. Petersburg, Berlin, and Paris, almost without break of journey in five days.

My brother had meanwhile - in 1859 - married the sister of the before-mentioned Mr. Gordon, a clever and charming lady. He brought his wife with him to Madrid, as she insisted on sharing the toils and the possible dangers of the enterprise. In Madrid it was unpleasantly cold and windy, so that I could not perceive that the climate had much improved since my leaving Moscow. We soon continued our journey to Aranjuez, Valencia, and Alicante, without even there finding a more genial temperature. The winter was unusually cold for Spain, and it was a curious sight to see on the whole way from Alicante to Cartagena date-palms and orange-trees abundantly laden with golden fruit covered with snow. Even in Cartagena, where we had to wait some days for the cable-ship, it was so 
bitterly cold in the houses destitute of fireplaces or stoves, that my sister-in-law often afterwards declared, that my fur brought from Russia had prevented her from freezing in Spain. It was not before Oran that we thawed again. The necessary preparations were soon made, and we rejoiced in the hope that the whole laying would be over in a few days. But "there's many a slip between the cup and the lip" - after four weeks" toil and undergoing of grave dangers we had lost the cable, and had to congratulate ourselves that we had not also sustained loss of health or life.

Judged from the cool standpoint of advanced age this cable-laying was an egregious piece of folly, since cable, ship, and mode of laying were utterly inadequate. As an excuse for our nevertheless undertaking it only the following reasons can be offered. We desired under any circumstances to lay a cable of our own, because we saw that our inventions and experiences were being turned to account by English contractors without any regard for us, and even without our undoubted services in the development of submarine telegraphy being so much as mentioned; and further, and perhaps mainly, because the cable-construction and paying-out arrangements devised by brother William were so well conceived and interesting, that we had not the heart to leave them unused.

The cable would have been excellent in every respect if it had remained in the condition in which it left the factory. We were however unfortunately soon convinced that its proper breaking strain had been 
much impaired, although the hempen strands were supposed to be prevented from "dry rot" by being impregnated with a solution of tannin. In spite of its light weight it was hardly strong enough any longer to be laid with safety in the considerable depths between the Algerian and Spanish coasts. Still worse almost was it that my brother had invented for the laying a new mechanism, which was now to be tried for the first time. It consisted in the cable being coiled round a large drum with stationary axis, which was to be turned for the winding and unwinding of the cable by a specially constructed small steam-engine. This contrivance, though carried out in a very ingenious manner by my brother, yet appeared to me very dubious, for the uniform rotation of so heavy a drum, especially in a rough sea, was connected with difficulties, whose extent could not be foreseen, and the portion of cable unrolled by the revolving drum could only be properly estimated when the ship's velocity, the ocean-depth, and the currents were at all times exactly known. But as the weather was calm and fair, and I had moreover constructed an electrically worked velocitymeter, which I desired to test, and which, as I hoped, would always accurately indicate the ship's speed, we resolved to make the attempt in spite of the decreased strength of the cable.

Unfortunately my fears proved to be justified. After the heavy shore-cable had been laid, and the laying of the light copper cable, connected with it, had proceeded for perhaps an hour without disturbance, 
so that my hope of success already noticeably rose, the cable suddenly broke and sank in the rather deep water, without any apparent reason. It was impossible to pick up again the cable already laid, as it was held fast at the sea-bottom by huge boulders. We had in consequence not sufficient cable left to undertake a laying to Cartagena, determined therefore to take the shorter course to Almeria, and in the first place to run across, with the object of searching for a suitable landing place.

The trip to Almeria with glorious weather and mirror-like sea was enchanting. The town is masked by a hilly neck of land, which stretches far into the sea. For our purpose this fine situation was certainly rather unfavourable, for it compelled us to make so wide a circuit round the promontory that the smaller linear distance from Oran was thereby almost neutralised. We landed however in order to take in stores, and enjoyed the hospitality of the inhabitants, who would not be denied giving us a festive reception and improvising in our honour an entertainment in the theatre. What most surprised us at this entertainment was the classical beanty of the women, whose features were undoubtedly of Moorish type. One young girl in particular struck us, who by the unanimous vote of our ship's company, composed of all nationalities of western Europe, was pronounced the ideal of female beauty. We did not dream on that enjoyable evening that the next day would bring us dangers, the surmounting of which still appears to me little short of miraculous. 
Rightly to understand what followed it must be borne in mind that our ship had not been built for cable-laying, but had only been procured in the English market ad hoc by the French government. It was an English coasting-vessel, whose former function had been to tow colliers to London. These ships are not built for the open sea; they have a flat bottom, no keel, and no high prow for breaking the waves. The hold of this unfavourably constructed ship was for the most part occupied by a huge wooden drum, with fixed iron axis, on which the whole cable was wound; the load was therefore very unfavourably distributed for the open sea. But the weather was uninterruptedly fine, and the sea calm. This changed somewhat when, after leaving Almeria, we had rounded the promontory, and saw the open sea before us. A moderate breeze was blowing from the south-west, and masses of black clouds hung behind the neck of land along the coast. Then it struck us that the nearest of these dark lowering clouds was continued to the sea-level by a long prolongation, and that the sea beneath was in wild commotion, so that it appeared in the unbroken sunshine as a dazzling and jagged icefield. Our vessel passed, according to our reckoning, about two leagues off this high foaming field, which was perhaps half a league broad, whilst the length could not be estimated. It was surprising that the prolongation, coalescing bluntly with the cloud above and then tapering quickly, did not come quite in contact with the heaving surface of the water, but 
remained separated from it by a clearly discernible interval. There was also no special elevation to be perceived of the foaming surface beneath, but the whole surface appeared to be raised uniformly as high as a house above the level of the sea. The end of the protuberance at the same time executed an undoubted circular movement above the white part of the sea, so that it returned about every ten or twenty minutes to the same point.

Unfortunately we could not long continue the observation of this interesting spectacle, a so-called water-spout, as it rather quickly drew off along the coast in an easterly direction, and we were also diverted from it by another remarkable phenomenon. For the ship began of a sudden to rock with such violence that we could only with difficulty maintain an upright position. They were short high waves, so-called dead sea, over which we were being borne. Clearly we were following in the wake of the water-spout. The violent rockings of the ship made the captain, who was well acquainted with its construction, very anxious indeed; he kept however his course in the direction of the troughs of the waves, in the hope of soon coming again into calmer water. Then dull short blows struck upon my ears, which made the ship tremble at every oscillation. The thought flashed through me like lightning, "the drum has got loose and will soon with irresistible blows knock the ship to pieces." I rushed into the cabin to my brother, who was already contending with sea-sickness; no one else 
knew precisely the construction of the drum and the mode of its attachment, he alone therefore could perhaps still save us. I found him already on his feet deadly pale, but composed. He too had immediately understood the cause of the threatening blows, and that had sufficed to dispel every trace of sea-sickness. In the hold he in fact saw that the axis of the drum had got loosened from its upper frame, and that the blocks of especially hard wood, which had been carefully prepared and fitted for the protection of the frame, were wanting. The French ship's carpenters at first pretended not to know what had become of them, but when the blows increased in strength, and my brother called out that we should all be lost, if the wood was not immediately brought, their memory returned, and the blocks were produced. The fellows had admired the unfamiliar solid wood and had regarded the pieces as superfluous.

With the violent rocking, we could not however succeed in placing the blocks in their proper places. Meanwhile the blows had increased to such a degree that everybody was seized with fear lest the vessel should no longer resist them. Then my brother called to us through the open hatch-way, "The oscillation is too great, steer against the wind!" The captain at once gave the necessary order, and the ship turned to mett the waves. A moment after to my astonishment I beheld the prow plunged under water, and the waves already washing over the fore-part of the deck. I perceived at once the cause of the phenomenon. 
The ship with its full velocity had turned too suddenly against the wind, and when a wave had once washed over and depressed the prow, it retained the inclined position and was driven down by its velocity on the incline. At this critical moment I involuntarily assumed the command, and called loudly into the engine room hard by "Stop!", as the captain was wont to do. Luckily the engine-men instantly obeyed. But the ship's velocity could only be slowly reduced. We all stood on the raised poop, and saw the fore-deck becoming continually shorter and the sea more and more approaching our standing place. Then the sea broke over the after-deck, and a mighty whirlpool was formed, the water pouring through the open hatch into the ship's hold. Our end seemed at hand. Then the swirl became weaker, and after some further anxious moments the prow once more appeared above the water, and we breathed fresh hope, for the violent rocking and the ominous blows had now ceased.

My brother, who in the hold had not been able to observe the approach of danger, was completely surprised by the sea-water suddenly deluging himself and the drum. All the greater was his delight when the rush of sea-water ceased, and it soon after became possible for him to adjust the wooden supports, and thereby prevent the dangerous blows of the axis of the drum. The eaptain now cautiously resumed the course to Oran. The vessel continued indeed still to rock disagreeably, but we got accustomed to it, and rejoiced that the drum did not stir again. The great 
excitement had dispelled all sea-sickness, and when it became dark every one sought his berth, and soon all was tranquil.

I had not been long asleep when loud orders and cries of alarm on deck awoke me suddenly. Immediately afterwards the ship laid itself on its side in a manner I have never since experienced, and can even now scarcely consider possible. People were thrown from their beds and rolled on the steeply inclined floor of the large cabin into the opposite cabins. They were followed by everything moveable on the ship, and at the same time all the lights were extinguished, as the hanging lamps were hurled against the cabin deck and shattered. Then followed after a brief anxious pause a recoil, and a few repetitions of nearly the same intensity. Immediately after the first shocks I succeeded in gaining the deck. I descried in the half-light the captain, who in answer to my call only pointed to the stern, exclaiming "voilà la terre!". Indeed a high rocky wall, feebly shining in the darkness, seemed to be standing behind the ship. On seeing it, the captain had suddenly brought the ship round, and thereby caused the violent oscillations. He thought we must have drifted, and were close on the rocks of Cap des lions. Suddenly a voice called in the darkness "La terre avance!", and actually the high uncanny gleaming wall now rose close behind the ship, and was advancing with a strange roaring voice. Then came a moment so awful and overpowering that it baffles description. Tremendous floods, which 
seemed to burst in on all sides, poured over the ship with a force which I could only withstand by convulsively grasping the iron rail of the upper deck. I felt how the whole ship was tossed hither and thither with tremendous force by violent short blows of the waves. Whether we were above or under water was hardly to be distinguished. It seemed to be foam, which we breathed with difficulty. How long this state of things lasted no one was afterwards able to say. Those also who had remained in the cabin had to contend with the violent shocks, which threw them hither and thither, and were terrified to death by the roaring noise of the mass of water falling down on the deck. The statements of time varied between two and five minutes. Then all was over as suddenly as it had begun, but the gleaming wall now stood before the ship, and slowly moved away from it.

When after a short time the whole ship's company collected with revived spirits on the deck, and talked over all the terrors and wonders, the French officers were of opinion that the most incredible wonder of all had been that our lady had not once screamed. The thoroughly English composure of my sister-in-law, growing with the rising danger, appeared altogether incomprehensible to the lively Frenchmen.

As we heard afterwards, the water-spout, which we had observed at Almeria, had moved eastwards down the Spanish coast, had then passed over to the African side, and we had manifestly crossed its path. That with our craft, so little sea-worthy, and so in- 
judiciously loaded, we had fortunately stood the dangerous experiment, is perfectly incomprehensible to me. When the water-spout had passed over us the sea still remained for some time in wild commotion, and, so far as we could observe, was covered with foaming crests. Then we beheld a natural phenomenon of a splendour and grandeur such as the most daring fancy could hardly paint. As far as the eye could reach the whole sea glowed with a dark red light. It looked as if it were composed of molten red-hot metal, and the foam-crests in particular of the procession of waves radiated so bright a light that all objects could be distinctly seen, and even the smallest writing: could be read. It was a beautiful eerie sight, which stands even to-day, although more than a quarter of a century has passed, with perfect distinctness before my mental vision! We were at a point of the sea, which was densely peopled by phosphorescent animalculae. A tumbler, which I filled with sea-water, shone brightly in the dark when the water was violently shaken. The wild swirling motion produced by the water-spout had excited the whole mass of phosphorescent animalculae, visible even to the naked eye, and to their universal simultaneous phosphorescence we owe the marvellous sight of the glowing sea.

In Oran, where a few hours later we landed without our journey being further disturbed, we had to consider what was next to be done. According to an accurate estimate we had still cable enough to reach Cartagena, if it were paid out with the least slack 
that was necessary for laying it without strain on the not quite level sea-bottom. My brother had become bolder through the luckily surmounted danger's and wanted once more to attempt the laying without more ado with the present contrivances. I opposed this, however, since I had lost all confidence in the drum, and the ship freighted with it. Finally we came to the determination to coil the cable over, and carry ont the laying in the usual way with cone and dynamometer.

When the troublesome and tedious coiling of the cable was finished and the fatal drum laid aside, we proceeded to our second attempt. The weather was again splendid, and the laying went forward without any difficulty. The depth of the sea however proved to be greater than was given in the French charts, and we were obliged to load the dynamometer to a hazardous degree, in order not to pay out too much cable. I controlled the expenditure of cable by my electric $\log$, which hitherto had always done good service. Thus things, went without disturbance, until we had already clearly in sight the high coast near Cartagena. Suddenly my $\log$ refused to act - as it subsequently appeared because its screw had got entangled in sea-weed. As my last reckoning had shown that we had cable to spare, and should arrive in Cartagena with a surplus, I went to my brother and requested him to unload the dynamometer somewhat, in order to be secured against the fracture of the cable. He was greatly delighted, and was about to show me first how beautifully and equably 
the cable was running out with the present loading; when all at once we saw the cable quite gently come asunder. The brake-wheel stood instantly still, the torn-off end disappeared in the deep, and therewith, for our then circumstances, a considerable sum of money, as we had undertaken the laying at our own risk. But what for the moment aggravated us still more than the money loss was the technical fiasco. The labour of months, all the toils and dangers, which not we alone, but also all our companions had undergone on account of this cable, were in a moment irrecoverably lost on account of a few rotten strands of hemp. In addition there was the unpleasant feeling of being the object of commiseration of the whole ship's company. It was a severe punishment for our temerity.

When a few hours after the breaking of the cable we landed in Cartagena, we had been over a month without news from Europe. In Almeria we had also not heard much in our flying visit, except that war had broken out with Denmark on account of the Duchies of Schleswig and Holstein. In the hotel at Cartagena we found French and English newspapers, and all the great political news of the last month from the Fatherland poured in upon us. An altogether remarkable revolution had taken place in the newspaper articles on Germany since the declaration of war and the defeat of Denmark, which enjoyed the favour of England. We had hitherto been accustomed to read in English and French newspapers much well- 
meant praise of German science, German music, and German song, as well as compassionate utterances on the good-natured, dreamy and unpractical Germans. Now there were furious articles on the conquestseeking, the war-loving, nay, the blood-thirsty Germans! I must confess that all this gave me no annoyance, - but considerable pleasure. My self-respect as a German rose higher with each of these expressions. The Germans had for so long been only passive material for the world's history. Now one might read for the first time in black and white in the Times, that they had of their own accord entered into its course, and thereby excited the wrath of those who hitherto had considered themselves alone entitled to the honour. In my intercourse with Englishmen and Frenchmen during the cable-layings I had often had painful occasion to be convinced in what slight esteem the Germans were held as a nation by other peoples. I had long political debates, which always came to this, that the Germans had neither the right nor the ability to form an independent and united state of their own. "Well, what then do the Germans exactly want?" asked the highly respected director-general of the French telegraphs, and former companion in exile of the Emperor Napoleon, M. de Vougie, after a long conversation on the reviving national aspirations in Germany at the close of the FrancoAustrian war. - "A united German Empire", was my answer. "And do you think," he replied, "that France would suffer a state united and superior in numbers to itself as next-door neighbour?" - "No," was my 
answer, "we are convinced that we shall have to defend our unity against France." "What an idea," he said, "that a united Germany would fight us. Bavaria, Wurtemberg, all South Germany will fight with us against Prussia." "Not this time," I answered, "the first French cannon-shot will make Germany one; we have no fear therefore of a French attack, but await it cheerfully." M. de Vougie shook his head; yet the idea seemed to dawn upon him that the Pandora box of the nationality question, which his ruler had opened in the war with Austria on behalf of Italy, might finally be turned against France. Three years later, when the question of the annexation of Lauenburg by Prussia was occupying people's minds, I paid a visit to the director-general in Paris. Remembering our political conversations he called out to me on entering the room: "Eh bien, Monsieur, vous voulez manger le Lauenbourg?" "Oui, Monsieur," I returned in answer, "et j'espère que l'appétit viendra en mangeant!" It has truly grown, this appetite, and been also appeased, and M. de Vougie will have thought of my prophecy when with his Emperor he had to retire before German troops entering France in triumph. The first French cannon-shot had in fact made all Germany one.

The Cartagena-Oran cable was an unlucky one for us. When the lost cable had been replaced by a new and somewhat stronger one, my brother repaired again in the same year to Oran. All the arrangements were excellently made, the experience gained in former 
expeditions being fully utilized. The cable was new and strong, the employés practised, the weather favourable - in short, a failure was this time not to be thought of. I received indeed at the expected time the hoped-for despatch from Cartagena, announcing that the cable had been successfully laid and messages already exchanged between Oran and Paris. Unhappily this despatch was followed only a few hours later by another, stating that the cable for unknown reasons had snapped near the Spanish coast. Closer enquiry showed that the fracture had occurred at a point where the Spanish coast slopes down abruptly to an unusual depth of water. The crossing of such submerged ravines, as in general of extremely uneven sea-bottoms, is always very dangerous. If the cable is laid in such a way that it rests on two rocks, which are so far elevated above the sea-bottom that it remains suspended on them without touching ground, it assumes the form of a catenary curve, whose tension may become so great that it snaps. Such a catenary curve the cable must at all events have formed at the foot of the abrupt declivity just mentioned, for the fracture occurred only a few hours after the cable firmly settled itself there.

The picking up of the cable was attempted, without success however, as the ground was rocky, the sea deep, and the cable not strong enough for such a depth. In short, we had also lost the second cable for good and all, and had no other satisfaction than the feeling of relief at being dispensed from the 
obligation of making another attempt by the circumstance that official despatches were actually exchanged between Oran and Paris.

The great losses, which these cable-layings brought us, caused a small crisis in our business relations. My partner Halske did not relish such undertakings attended with risks and serious losses, and feared also that the venturesome spirit of my brother William might entangle us in enterprises suited to the large scale of English commercial life, but to which our resources were unequal. He therefore proposed the giving up of our English house. William Meyer as business manager of the firm ranged himself on Halske's side. Although I could not but admit the weightiness of the reasons adduced, I still could not bring myself to leave my brother William in the lurch at so critical a juncture. We accordingly agreed that the London business should be entirely dissociated from the Berlin house, it being taken over by me (at my private risk) and William. This was carried out, and the London business now became the firm of Siemens Brothers. Brother Charles in St. Petersburg likewise entered as partner. Between the three now independent firms in Berlin, St. Petersburg, and London, agreements were drawn up to govern the mutual relations.

I may as well remark here that the copper-armed cable laid by the London firm in the Black Sea in 1869, of similar construction to the Cartagena-Oran cable, likewise did not prove durable. It was laid by my brother William with complete success as part of the 
Indo-European line, which I shall speak of later on, between Kertch and Poti parallel to the shore, but the very next year was destroyed by an earthquake simultaneously at many points. On attempting to take it up again it appeared that this was not possible, as it was covered for the most part with rubble and earth. This, and the circumstance that the interruption of the telegraph service took place just at the moment, when a severe shock was felt at the coast station, Suchum-Kalé, proved that the breaking of the cable had actually been caused by the earthquake. This is moreover quite intelligible, since soil and rubble, deposited on the shelving shore, are carried down to the sea by numerous water-courses. From time to time these masses must slip further, when a cable imbedded in them will of necessity be torn. The movement alluded to could not but be initiated by an earthquake simultaneously at all places where the equilibrium had been rendered unstable by recent deposits.

Through these and similar occurrences we have learnt the lesson that submarine cables should never be laid on the slope of steep declivities, and especially not where soil and rubble are carried to a deep or inland sea by rivers discharging into them.

We may regard the period of the cable-layings described in the foregoing as our proper apprenticeship for such undertakings. Instead of the anticipated profit they brought us many anxieties, personal dangers, and serious losses, but they paved the way for the successes, which subsequently fell to the lot of our 
London firm in its important and well-executed cable undertakings. I shall hereafter return to this second period of our cable-layings, but only briefly review it, as I personally had less share in the labours connected with them.

I now turn to continue the short summary of my scientific and technical labours already brought down to the year 1850 .

In the years 1850 to 1856 I was busily engaged with Halske in improving telegraphic apparatus, electrical appliances, and measuring instruments for scientific and technical purposes. It was still a tolerably unploughed field which we worked over, and our activity was accordingly extremely fertile. Our constructions, which were rapidly made known, especially through the Universal Exhibitions in London and Paris, have almost everywhere formed the basis of later contrivances. As already remarked, only a few of these innovations were patented, the majority of them were either not at all, or only in later years, described in journals. This facilitated indeed their general introduction and brought us many orders, but at the same time we lost in many ways the universal acknowledgement of their origination. I shall here only instance a few of the directions which our constructive activity took.

Besides the practical development of the Morse telegraph for hand use, we were occupied in this 
period with the elaboration of that apparatus into an express-writer for our automatic telegraph system, which was originally destined for the great Russian lines, and came first into operation on the WarsawSt. Petersburg line in 1854 . In this system the messages were prepared by the so-called three-keypuncher, whose object was to impress the Morse signs on a paper ribbon, in which by depressing the first key a single round hole, by depressing the second key a double hole, was cut out in the ribbon. The necessary pushing forward of the ribbon took place automatically, whilst the greater interval required for the separation of the words was produced by the depression of the third key. When in this manner a message had been punched into the paper slip, the latter was drawn along in the so-called expresswriting-transmitter by help of wheel-work between a roller coated with platinum and a contact-spring or brush. By this means the single holes produced a dot, the double holes a dash at the receiving station. As it turned out that ordinary magnets with iron armature did not work quickly enough, we employed for the relays as well as for the inkers light cores, capable of turning in the stationary coils of the magnets, which were formed of bundles of wires or of thin split iron tubes, whereby the desired velocity could be attained with certainty.

Bain had as early as 1850 employed a perforated slip of paper for his electro-chemical telegraph, but he had no suitable mechanism for rapid punching of 
the slips. Wheatstone made good use of my threekey-puncher in 1858 for his electro-magnetic expresswriter, without however naming the source whence he derived it.

The signalling service of the railways, with which our firm had from the first been particularly occupied, brought further problems. On all the German railwaylines ringing-apparatus had to be set up, which on the departure of a train from a station should give audible bell-signals for the whole distance. The mechanician Leonhardt had already provided such gong-apparatus for the Thuringian line, but they acted imperfectly, as it was difficult to maintain in good condition the large galvanic batteries, which were required at the stations for setting the apparatus to work. It was an obvious idea to employ magnetic inductors instead of batteries, but the magneto-induction machines, known up to that time, of Saxton and Stöhrer were not suited for the purpose. We now constructed a new kind of such inductors, which worked admirably, and afterwards entirely superseded all other constructions. 'The essential feature of our inductor was the employment as a rotating bar of an iron cylinder, which was provided with deep opposite grooves, forming a channel for the reception of the coil of copper wire. From the form of its iron cross-section this bar received the name of the double ' $\mathrm{I}$ armature; in England it is known as the Siemens' armature. The steel magnets, hollowed out at the end, which surrounded the rotating cylinder, could be set 
up along it apart from one another, accordingly exert a more powerful magnetizing effect and less impair each other's action. Inductors of this kind are to-day exclusively employed wherever it is desired to procure powerful currents by permanent magnetism.

My cylindrical bars with transverse coil possessed the great advantage over the older constructions that they had with powerful action less mass, and especially with quick rotation little inertia. I employed them therefore also for the construction of a very simple and surely acting magneto-electric dial-telegraph, in which the cylindrical inductor was quickly turned by a handle with wheel-translation, whilst each semi-revolution sent an alternating positive and negative current through the line, each causing the pointer of the receiving apparatus to advance by one letter on the dialplate. It was enough to place the handle successively on the letters to be telegraphed, to make them visible in like order at the receiving station. The electromagnet of the receiving apparatus consisted of an iron cylinder with polar extensions revolving on its axis, which oscillated between the poles of two powerful horse-shoe steel magnets. Therefore, according as a positive or negative current traversed the fixed coils of the electro-magnet, one or the other magnet attracted the rotating armature, and thereby kept in motion the hands of the receiving apparatus. This quickly and surely acting magneto-electric dial-apparatus was in great requisition especially for the railway service, and is even now frequently used. 
The arrangement just described of polarized magnets - i. e. those in which the oscillating bar or magnet has two resting places, according as a positive or negative current has last traversed the electromagnetic coils - has obtained more considerable and general importance through their being used for relays. On the employment of polarized relays depends the possibility of telegraphing the Morse alphabet with short induced currents, the one direction of the current initiating a dash on the paper strip, while the other completes it. The length of the produced dash accordingly does not depend on the duration of the current, but on the duration of the interval between two short successive currents of alternate direction.

On this principle depend several of our telegraphic constructions, of which only the induction writing-telegraph need be mentioned here. In this the short currents of alternate direction required for its working were produced by a well-closed electro-magnet, round which was wound a primary coil of short thick wire and a secondary of long thin wire. In the primary coil the currents required for telegraphing the Morse alphabet were produced in the usual way. In the secondary coils connected with line and earth there then occurred, at the beginning and close of the currents circulating in the primary conductor, powerful induced currents of alternate direction, which produced the required Morse signs in the telegraphic apparatus at the receiving station. For the magnetic inductors magnetically closed electro-magnets with 
massive iron cores were employed, to make the tension of the closing and opening currents equal as far as possible.

With such inductive writing-telegraphs it was possible by means of a single Daniell battery to telegraph with certainty at the greatest distance on overhead lines. For underground and submarine lines also the induced electric currents proved highly advantageous, for they made it possible to signal to greater distances and with greater speed. As already mentioned the Sardinia-Malta-Corfu line was fitted in 1857 with our induction writing-telegraphs. For the working also of the first Atlantic cable laid in the following year by the managing electrician, Mr. Whitehouse, induced currents were made use of, until the destruction of the insulation, which unfortunately occurred soon after the laying, prevented their further employment. Subsequently recourse was again generally had on long submarine lines to Thomson's mirror-galvanometer with battery currents.

For land lines also there was this drawback to the use of short induced currents, that they had to be very powerful to be able to produce the necessary mechanical movements at the end of the line. But since the keeping in condition of very large batteries. such as the working of long lines with uniform current or intermitting battery current requires, was troublesome and costly, Halske and I tried to transform mechanically battery currents of low tension into uniform currents of higher tension. We exhibited, at the 
Universal Exhibitions of London and Paris, several mechanical arrangements constructed by us for this purpose, but they had at first the drawback that the currents of high tension obtained were not of uniform intensity. It was only through the construction of my so-called "plate" machine that the problem of the production of uniform currents of nearly constant tension by voltaic induction was actually solved.

This "plate" machine consists essentially of a large number of electro-magnets, which are grouped in a circle, and the so-called "plate", a conical piece of iron, whose apex lies in the centre of the circle of magnets, is set rotating above their poles. The magnets are furnished with double coils, of which one half of the inner ones are always inserted in the circuit of a battery composed of a few large elements and by a suitable contact arrangement - the contact being always a fourth of a revolution in advance of the rolling "plate" - cause the rotation of the plate, whilst the outer ones are collectively united into a closed conducting circuit. The iron cone by rolling over the magnetic poles produces in the secondary coils of the magnets inserted in the battery circuit an induced current in one direction, but on the other hand in those of the magnets outside the battery circuit an induced current in the opposite direction. The two induction currents would neutralise one another, and no current could at all arise in the secondary circuit, unless at two oppositely situated points of this circuit there was a continuous contact, by which the opposed 
currents of both halves were taken up and united into a continuous current. This contact is effected by means of brushes, which are moved round by the prolonged axis of the iron cone.

The "plate" machine was constructed by me in 1854 and shown at several Universal Exhibitions, first at the one held in Paris in the year 1855. One of them together with other apparatus of our construction is preserved in the museum of the Berlin Post Office, which probably possesses the most complete collection of old telegraphic apparatus anywhere to be found. The "plate" machine is interesting, because it represents the first solution of the problem, how to generate by induction continuous currents in one direction, and follows precisely the same course as that taken by Professor Pacinotti ten years later in constructing his famous magneto-inductor; the principle of current ramification, which is carried out in the ring of Pacinotti, being already contained in it. $\mathrm{My}$ machine is thus the precursor of the modern dynamo machine with continuous current and at the same time of the transformer. Had the self-motion of the plate not been made a point of, and had it been effected by mechanical revolution of the axis together with the brushes, an effective dynamo-electric machine would even then have been obtained, and the intervening period of the employment of the Siemens' armature would have been skipped. This may serve as an instance of the difficulty which is often experienced in first apprehending the most obvious 
truths. Indeed I can only think with a certain sense of shame of the circumstance that, after establishing the principle of the dynamo machine. I did not at once hit upon the parallel connection of the two halves of the coils with opposed induction, employed in the "plate" machine, but was only led to it several years later by Pacinotti's example.

In the year 1854 telegraph engineers were greatly excited by a statement which appeared in the Leipzig Polytechnic Centralblatt. The statement was to the effect that the Austrian telegraph official Dr. Gintl had succeeded in telegraphing between Prague and Vienna by means of the Morse apparatus simultaneously in opposite directions through the same conducting wire. This was said to have been accomplished by providing the relays with two coils, through one of which the main current passed, while at the same time an equally strong local current passed through in the opposite direction. This second circuit had to be closed by a separate contact at the same moment as the main current. Dr. Gintl however soon found that this path did not lead to the desired end, because it was impossible to let two contacts actually occur at the same moment, and because the interruption of the main current taking place at the end of each signal could not but disturb the current coming from the other side. Gintl therefore abandoned this method and tried to solve the problem by making use of Bain's electrochemical telegraph. His experiments then yielded a better result. and betrayed him into the belief that two 
currents with opposite directions could traverse the same conductor without mutual interference. In an article "On the forwarding of simultaneous messages through one telegraphic conductor", which I contributed to Poggendorff"s Annalen, I demonstrated the inadmissibility of this view, and expounded the theory of electro-chemical duplex telegraphy, but also showed that this method was not capable of practical application. At the same time I described a method of duplex telegraphy with electro-magnetic apparatus, which completely accomplished the desired result. The same method was also independently discovered by the subsequent chief engineer of our firm, Herr C. Frischen in Hanover. It is known at the present day by the name of "Duplex signalling method of Frischen and Siemens" and is still frequently employed. At the close of the above-mentioned article I dealt with the theory of signalling with two apparatus in the same direction along the same wire and with that of simultaneous transmission in the same and in opposite direction, described also the current ramifications whereby these problems can be solver.

In the year $1857 \mathrm{I}$ published in Poggendorff"s Annalen a longer article "On electro-static induction and the retardation of the current in jar-wires", which gives the final result of several year's' experiments on the physical properties of underground conductors. In this I took up again and developed further the theory of the electro-static charge of underground conductors broached by me as early as 1850 . This theory 
obtained at first but little credit in scientific circles; even William Weber trying to explain the disturbances occurring in the Prussian underground conductors by self-induction. Faraday's ingenious theory likewise, according to which the electro-static induction is not effected by direct electric action at a distance, but by the induction proceeding from molecule to molecule of the dielectric, was unable to obtain acceptance with most physicists of the old school. The actual influence of the matter between two conductors on the extent of the electric charge was explained by a more or less profound penetration of the electricity into the insulator and the diminution of the distance thereby cansed between the effective quantities of electricity in the two conductors. I determined therefore to carry out an experimental investigation, in order to establish the actual state of things without connecting it with any of the existing theories. My investigation, which was made considerably more difficult by the then very imperfect development of the means and methods of investigation, led to a complete confirmation of Faraday's molecular distribution theory. The result arrived at was, that the laws of the motion of heat and electricity in conductors also applied to electro-static induction, and that consequently the form of Ohm's law for the electric current is applicable to it likewise. I obtained in this way with the help of Faraday's theory Poisson's formulae for the density of electricity at the surface of bodies, and was able to furnish an experimental proof that in all cases the 
theory of Faraday suffices for the explanation of the phenomena. I then carried this theory further in several directions and solved problems by the help of it, as e. g. the calculation of the capacity of a battery formed of any number of Leyden jars of different capacity placed one behind another, a problem which up to that time had not been solved. Unfortunately I did not find the necessary leisure before the spring of 1857 to prepare my work for the press. Meanwhile eminent English physicists, like Sir William Thomson and Maxwell, had anticipated sundry of my scientific results; in particular the formulae, given by Thomson. for the capacity of jar wires and the retardation of the current were the same as those which I had arrived at in a quite different and more elementary way. Maxwell has in his masterly works elaborated Faraday's theory in strict mathematical fashion, and proved that it is everywhere in complete harmony with the theory of potentials. We are therefore completely warranted in regarding with Faraday electric distribution as an action propagated from molecule to molecule, but not combined with a direct action at a distance, for only one of these processes can actually take place.

At the close of the above-mentioned paper I described the apparatus known by the name of the Siemens' ozone tube, and explained the theory of its action. I succeeded with its help in converting oxygen into ozone by electrolysis. There is still a great future in store for this apparatus, as it enables us to subject gases to 
electrolysis. They are put by it into the so-called active state, rendering them capable of forming directly with other gases chemical compounds, which could otherwise only be obtained in a very roundabout way.

I have already mentioned that even in the middle of this century one of the greatest obstacles in the way of the development of the physical sciences, and especially of physical technology, was the want of fixed standards. In scientific writings pretty generally metre and gramme were used as measures of length and weight, but notwithstanding technology suffered from an insupportable looseness and inaccuracy. Metre and gramme at any rate always formed fixed points of comparison, to which all estimates of measure could be referred. Such a fixed point was entirely wanting; however, for electric standards. William Weber indeed had already, in conjunction with Gauss, theoretically developed the admirable system of absolute magnetic and electric units, and had also perfected to an extraordinary degree the methods of exact measurement and the requisite instruments, but standard tallies, representing the absolute units and accessible to everybody, were wanting. It was in consequence usual for every physicist to set up his own standard of resistance, which was attended by the serious inconvenience that the results of his labours were not then comparable with those of others.

Jacobi in St. Petersburg then made the proposal to take as general unit of resistance an arbitrarily chosen copper wire, which he deposited with a Leipzig 
mechanician. This attempt, however, fell through, because the resistance of the wire changed in course of time and the copies supplied showed values varying as much as ten per cent from one another. The resistance of a German mile of copper wire of one millimetre diameter at first employed as unit by Halske and myself, and pretty generally adopted in Germany and other countries for practical telegraphy, proved also to be only a makeshift. I soon became convinced that it is quite impracticable to set up an empirical standard in the manner of Jacobi, as the electrical resistance is not such a fixed and controllable property of bodies as (say) the dimension and mass of solid bodies. There was also no prospect of inducing the whole world to accept a standard of resistance deposited in any particular place.

On these grounds the choice remained between the absolute unit of resistance of Weber and an empirical unit everywhere reproducible with the greatest exactitude. Unfortunately the adoption of the absolute unit was not then to be thought of, its reproduction being too difficult, so that William Weber himself declared to me that errors amounting to a considerable percentage were unavoidable. I decided therefore to take, as the basis of a reproducible standard of resistance, the only metal fluid at ordinary temperatures. mercury, whose resistance cannot be affected by molecular variations and is influenced less by changes of temperature than that of the solid metals available for the gauging of resistances. In the year $1860 \mathrm{my}$ 
labours had so far progressed that I was able to come before the public with the proposal to adopt as unit the resistance of a column of mercury of 1 metre in length and 1 square millimetre in cross section at $0^{\circ} \mathrm{C}$, and to publish my method of producing this mercury unit. The paper, which appeared in Poggendorff's Annalen, was entitled: "Proposal for a reproducible standard of resistance."

Although Mr. Mathiessen in London violently opposed the adoption of my unit and recommended instead as empirical unit a wire of gold and silver alloy with about the same resistance as Weber's unit, my proposal was soon generally adopted, and the Vienna International Telegraph Conference of the year 1868 made the mercury unit the legal unit of telegraphy. Nevertheless the English physicists continued their efforts to introduce as international standard the centimetre-gramme-second-system of resistance proposed by Sir William Thomson and adopted by the British Association - the so-called c. g. s. unit - a resistance ten times as great as that of Weber's absolute unit. The British Association appointed a special committee, to which Sir William 'Thomson and also my brother William belonged, which carried on a lively agitation for the general adoption of the British Association unit, although there had as yet been no really exact representation of the same. Reliance was placed. however, on the expected progress in electrical methods of measurements, and it was justly urged that the adoption of a theoretically fixed standard of resistance, 
based on a fundamental dynamic standard, would considerably facilitate calculations with electrical forces. Although on the other hand it could be contended that the great majority of calculations with electrical resistances belonged to the geometrical and not to the dynamical domain, and that the reproducible unit with a geometrical foundation proposed by me might just as well be called an absolute one as the unit of Weber resting on a dynamical basis, or the modification of the same which was proposed as unit on the English side, yet the c.g. s. unit of resistance has been subsequently adopted in principle as the international standard. I shall once again return to this in the sequel. The duty, entrusted to my brother William and myself by the English Government, of controlling the manufacture of cables subsidized by it, caused us to make very exhaustive experiments with regard to the properties of submarine lines, and especially to elaborate a rational method for the testing of their electrical condition. The Malta-Alexandria cable was the very first which was subjected to a systematic testing and controlling during its entire preparation, and which in consequence proved also perfectly faultless after being laid and has remained so. Such a rational testing was rendered possible by the exact standard of resistance above described, and by our arrangement of resistance coils, which allowed the combination of any desired resistances in mercury units in the same manner as weights are used in scales, furthermore by essential improvements, which the methods of in- 
vestigation and the measuring instruments underwent at our hands. For investigating the influence, which the high pressure prevailing at great depths exerts on the cable, steel tanks that could be closed were constructed, and the insulation of the cables measured, whilst they were subjected therein to a strong pressure. The fact already observed by us during the laying of the Red Sea cable was hereby confirmed, that the insulating capacity of the gutta-percha is increased by the pressure of the water, whereby the possibility was established of laying submarine lines even at the greatest depths. We further drew up tables for calculating the extent of the diminution, which the insulating capacity of gutta-percha, india-rubber and other insulating materials undergoes through increasing temperature, as well as for the diffusive capacity specific induction - of these insulators. Our experiments showed that in these points india-rubber and its compounds are far superior to gutta-percha, a circumstance, which caused us to institute extensive experiments, to obtain a good insulation of conductors by coating with india-rubber, but which did not quite lead to the sought-for practical results.

A paper communicated by us in the year 1860 to the British Association - entitled "Outline of the principles and practice involved in dealing with the electrical conditions of submarine electric telegraphs" - sunmarized the main results of our inquiries, and forms the foundation of the system of testing cables and detecting their faults which was afterwards generally 
adopted. But although this paper was published in English and my communication to the Paris Academy of 1850 , in which my methods of detecting faults were likewise in principle contained, in French, yet later writers and inventors have only in a few cases taken note of them, and have with slight variations published as new discoveries the methods therein given. I merely call attention to the point here, in order that the history of the development of electrical technology may not be permanently falsified. A recent book, compiled with much industry, bearing the title "Traité de télégraphie sousmarine" by E. Wünschendorff gives occasion for this remark. At the very beginning of this work the original inventor of the electric telegraph, the German Dr. Soemmering, is designated as "Professeur russe", who is said to have laid conducting wires under water near St. Petersburg and in 1845 near Paris, and to have thereby become the inventor of submarine telegraphy. While, for an historical work, this is certainly a surprising confusion of the German Dr. Soemmering with the German Professor Jacobi living much later at St. Petersburg, it is to be remarked that this and other projects of submarine communication before the year 1847 are only to be regarded as freaks of fancy, which could not possibly lead to practicable underground communication. It was my conductors with a seamless guttapercha coating that first solved the problem of the construction of underground and submarine lines, and the wires laid by me for the mines in Kiel harbour, 
and the iron-armoured cable-wire across the Rhine at Cologne in the spring of 1850 , formed the first actual basis of submarine telegraphy. The German name of the Frenchman Wünschendorff may perhaps have contributed to the ignoring of German achievements running through the whole work!

To the last described section of my activity belong two more events, which were of great importance to me.

In the year 1859 I was elected a member of the Council of the Berlin Merchants' Company, which forms at the same time the Chamber of Commerce of the March of Brandenburg. The election takes place by a poll of all the trading and commercial firms, and is accordingly regarded as a special distinction. Through this I gained the advantage of coming into closer personal contact with the heads of the Berlin industrial world. - When in the year 1860 the University of Berlin celebrated its jubilee I received the degree of Doctor honoris causa in the philosophical faculty. The granting of this honorary title in my chosen home Berlin gave me especial pleasure, because I saw in it an acknowledgement of my scientific labours and was brought by it into a sort of academic relation to my scientific friends.

I come now to speak somewhat in detail of my political activity, to which I devoted myself with much ardour in the following years. 
From my earliest youth I had felt keenly the want of union and the impotence of the German nation. 'This feeling had been awakened in me and the brothers nearest to me in age through our living in the petty and middle states of Germany, where a patriotism arising from a sense of political unity found no fruitful soil, as was the case in Prussia, thanks to its glorious history. Moreover in our family national and liberal views had always prevailed, and my father in particular was devoted to them. In spite of the melancholy political condition into which Prussia and all Germany had again sunk after the glorious War of Liberation, yet the hope remained that the state of Frederick the Great, who by his deeds had awakened self-confidence in the Germans, must prove our future saviour. It was this hope which had caused my father to advise me to enter the Prussian service, and in myself also this trust in a future raising of Germany through Prussia had always been strong. Hence I was carried away by the national movement of 1848 with such irresistible force and in spite of opposing private interests drawn to Kiel, to fight with Prussia for Germany's unity and greatness.

When this movement of youthful enthusiasm, altogether overshooting the mark, had collapsed through the unfavourable circumstances of the time, when Germany again had relapsed into impotent disunion and Prussia had been deeply humiliated, a profound dejection crept over all German patriots. Our hope indeed was still fixed on Prussia, yet no one any longer 
believed that Prussia as a state would secure the union of Germany, but our hope rested entirely on the ultimate victory of liberal sentiments in the German and particularly the Prussian people. This revulsion of feeling explains the events of the period of conflict, which would be scarcely intelligible without it.

Up to the year 1860 I was so fully occupied with scientific and technical labours that I kept entirely aloof from politics. Only when under the Regency of the Prince of Prussia the political stagnation and the pessimism, which had till then almost exclusively prevailed, had diminished, and freeer political views had again ventured to come forth, did I join the National. Association formed under the lead of Bennigsen, and patronized by Duke Ernest of Saxe-Coburg and Gotha. I was present at the meeting which constituted it at Coburg, and continued to take part in its aims as faithful ally. Through this and my lively activity at the elections for the Diet I became more intimately acquainted with the leading politicians of the liberal party. I attended the meetings of the new liberal party then in process of formation, and assisted at the deliberations concerning its programme and name. The majority was inclined to vote for the name of "Democratic Party", whilst Schulze-Delitzsch wished to call it the "German Party". I proposed the name of "Progressive Party", as it seemed to me more. proper to designate the direction of activity rather than the principles by the party name. It was resolved to combine my proposal with that of Schulze- 
Delitzsch and to call the new party "German Progressive Party".

The invitation to allow myself to be elected deputy I had repeatedly declined, considered it however my duty in the year 1864 to accept the election, which had taken place without my intervention, as deputy - for the district of Solingen-Remscheid. The reorganisation of the army proposed by the Government formed at that time the great question determining party lines. The essence of this question consisted in the doubling of the Prussian army, already being carried ont in accordance with the Government plan, and the corresponding increase of the military budget. The voice of the country declared that this increase of the military burdens could not be borne without leading to a thorough impoverishment of the people. In fact the prosperity of Prussia was considerably behind that of the other German states, as the burden of the German defences had even after the War of Liberation rested chiefly on her shoulders. If this burden was to be still further increased in so great a degree without the enforcing of a corresponding participation of the rest of the German states, it was thought the prosperity of the country could not but retrograde more and more, and the burden would finally become insupportable. It was known indeed that King William had already as Prince of Prussia and as Prince Regent been convinced of the necessity of raising again the state of Frederick the Great to the height consistent with its historical position at the head of Germany, 
and no one questioned the sincerity of the personally popular and highly esteemed monarch, whose efforts were directed to that end, but there was much doubt in regard to the practicability of his plan. Faith in the historical mission of Prussia for effecting the unification of Germany and in Prussia's star had sunk too low. Even the most eager enthusiasts for Germany's unity and future greatness, nay even preeminently Prussian patriots, deemed it therefore incompatible with their duty to load Prussia with this new, and as it seemed exorbitant, military burden. The representatives of the people rejected, in large part certainly with heavy heart, the reorganisation plan of the government, and after repeated dissolutions the people confirmed this vote at the new elections.

It was especially hard for me personally to vote against the proposition of the Government, as in my innermost heart I still maintained my old faith in the vocation of Prussia, and it might also look like ingratitude if I opposed the desire of a monarch, who had once personally shown his good will to me. Moreover, from the attitude of the ministers von Bismarck and Roon in the chambers and from their demeanour and utterances in the bitter war of words that often took place, I had gained the conviction that serious action was before us, for which an increased army would be required. But my political friends quieted me by saying, that an active movement on the part of Prussia for creating a united Germany under the guidance of Prussia would necessarily lead 
to a war with Austria, and against this there stood as insuperable obstacle the testamentary admonition of Frederick William III. to his son: "Hold fast by Austria!"’

This inward conflict led me, in an anonymous pamphlet, published by Julius Springer with the title "On the Military Question", to discuss the question, whether the doubling of the army in the event of war might not be obtained in another way than that proposed by the government, without the country being burdened with the serious expenditure, which the government plan rendered necessary.

Meanwhile the reorganization itself was carried through by the minister of war von Roon without any regard to parliamentary contests, and fortunately already completed when in the spring of 1866 the differences in regard to Schleswig-Holstein led to a breach with Austria. That this breach would actually occur and entail war few believed, despite the warlike preparations and threats. All the greater was the universal astonishment when early in the morning of the 14th of June the news spread, that war had been declared against Austria and the German Confederation, and that the declaration of war was already posted up on the advertising-pillars. In fact after a hasty walk from Charlottenburg to Berlin I found the nearest of these pillars surrounded by a dense crowd. I was struck by the calm earnest demeanour with which the often changing crowd received the mighty event. No criticizing remark of any sort was heard when the 
serious and dignified announcement was repeatedly read at the request of the bystanders. Everyone, workman and privileged citizen alike, felt the immense gravity of the fact "It is war!", but nobody appeared to be depressed by it, everywhere it was received with self-conscious calm. It was brought strongly home to me, what a power lies in the glorious past of a people. In perilous times it enhances selfconfidence, allows no pusillanimity to spring up, and awakens in everybody the resolve to contribute his part to overcoming the danger, as his fathers had done before him. As in front of this advertising-pillar at the Potsdam Gate so did it look in all Berlin, nay in the whole country, at any rate in the old territories of Prussia. All political disputes were forgotten or at least postponed. Every man had but one thought: to do his duty. That this feeling dominated all classes of the people was clearly manifested in a meeting, which was called on the very day of the declaration of war by some private persons, with the object of forming a society for the care of the wounded. When a politician began the proceedings with complaints against the government, which had brought on the war, a brief remark of mine sufficed for reply that war was now a fact, and the only question before us was, how to pave the way for victory, and assuage as far as possible the sufferings of the wounded. This was received with such unanimous applause that all further discussion was cut short, and the formation of the aid society for the 
army in the field, which afterwards worked with great success, was unanimously resolved.

When after a few weeks the war was ended with the prostration of Austria and its allied German states, the world looked quite different. The insignificant, deeply humbled Prussia now stood in fact as proud conqueror without a rival at the head of Germany. With a wise understanding of the national mind, which regarded the unavoidable civil war only as a means to the attainment of the yearned for German unity, King William and his chief minister had imposed only extremely mild conditions of peace on the conquered states, where they were not entirely incorporated in the Prussian state for its necessary security. The

- victorious King and Captain also gave the world a probably unique example of self-conquering justice, by requesting from the Diet an indemnity for the transgression of its constitutional rights necessitated by state difficulties, and thus restored the country's internal peace. It required certainly many more struggles in the Chamber of Deputies, before the wisdom and magnanimity of this kingly act received full recognition and approbation.

Through the struggles continued for several years with the government and the repeated dissolutions a sort of fighting organization had been formed in the Diet, which gave the leaders a decisive influence on the divisions. Waldeck in particular, the leader of the extreme democrats, had obtained great power. His friends rejected all compromise, and held it to be 
requisite for attaining their ends, as well as befitting the dignity of the House, to grant the desired indemnity only on very far-reaching conditions. This in the then. political situation was an extremely dangerous proceeding, which seriously threatened the internal peace, and might again imperil all the achievements of the glorious victories of the Prussian army. I had, soon after the conclusion of peace and before the convocation of the Diet, stopped some time in Paris, and had opportunity to become acquainted with the feeling of the masses, as well as of the leading circles. It was there considered as altogether beyond question that France could not suffer without very considerable compensation the powerful position acquired by Prussia at the head of North Germany and as leader of all Germany, and must break it down, if necessary, by force. From a thoroughly reliable source I learnt that the reason, why France had hitherto put a good face on a bad business, was merely because the Mexican war had disorganized the army and in particular exhausted the stores, but that warlike preparations were proceeding at a great pace, and in the meantime a prolongation of the internal conflict in Prussia was being reckoned upon.

$\angle$ On my return to Berlin I found the Chamber of Deputies already assembled and the indemnity question being hotly debated within the parties. Unfortunately a large number of the parliamentary leaders not belonging to the Waldeck party, in the fixed expectation that this group would carry the day at any rate in the 
Progressive party, had announced their secession from the latter and declared for the formation of a new party, the "National Liberal". I myself had on principle never delivered long speeches in the House, as I regarded my political activity as only transient, and had resolved not again to serve in Parliament. On the other hand I had always taken an active share in the party meetings and knew the leanings of most of the deputies perhaps better than the parliamentary leaders. It was my conviction that the great majority of the Progressive party were disposed for peace with the throne, and that it only required a powerful impulse to give expression to this peaceful sentiment. In fact my vivid description of the many-sided dangers, which were connected with the refusal of the indemnity, fell in the party meeting on fruitful ground, and after Lasker, who at my request had put off his declaration of withdrawal till after the sitting of the party, had confirmed my arguments in an eloquent speech, the Progressive party by a considerable majority declared for the unconditional granting of the indemnity, although Waldeck himself pronounced most decidedly for unflinching insistence on the point of right and the refusal of the indemnity. When thereupon the granting of the indemnity was also resolved by the House itself and thereby internal peace was restored in the country, I retired from the political scene and henceforth devoted the leisure time, which the management of my firm left me, to my scientific pursuits. In the three year's of my parliamentary activity 
I took an active part in the sittings of the committee and party meetings on the three only bills which obtained legal force by arrangement with the Government and the Upper House. I was special reporter of the division "Metals and metal goods" of the FrancoGerman commercial treaty, and believe that I materially contributed to its final adoption by a minute report which I drew up on this most hotly disputed part of the treaty. Unfortunately this report brought me into conflict with my constituents. 'The latter sent a special deputation to the Chamber, to protest against the article which forbade the marking of manufactures with the names of firms and trade-marks of the manufacturers of another country. The Solingen and Remscheid manufacturers declared that it was a customary practice to label the better class of goods, principally ordered by English manufacturers and dealers, with an English trade-mark, and that their business would be seriously injured if this were disallowed; the consequence of such a prohibition would be that they would not only lose the English, but also the German market for their superior goods, as even in Germany English goods were preferred.

In spite of long discussions we could not arrive at an understanding. The deputation admitted that German industry was acting suicidally in representing its good wares as foreign and only its inferior wares as its own manufacture, it threw the blame, however, on the purchasing public which demanded it. We accordingly parted in disagreement, and I believe I 
should not have been re-elected if I had. stood again. For the rest the prohibition has worked well, although unfortunately it has not been carried out in all its strictness. Since then in that old and famous seat of industry, as in general throughout Germany a manufacturing pride has grown up, which only permits the supply of articles of good quality, and it has also come to be seen in many ways, that a more effective protection is afforded by the good name of the manufacturers of a country than by high protective duties.

An effective system of protection, securing the consumption of the produce of native industry, can in fact only be consistently carried out, if the country, as e. g. the Uniteds States of North America, includes all climates, and itself produces all the raw materials which its industry needs. Such a country can exclude all imports, but thereby at the same time diminishes its own exports. It must be regarded as a fortunate circumstance for Europe that America by its prohibitively protective system has checked the rapid, and for us dangerous, development of its industrial resources, and restricted its own exporting power. Europe, divided by high tariff barriers, thereby gains time to perceive the danger of its situation, which will make competition with a free-trading America in the world's market impossible, if it does not in good time present a united front by a thorough mercantile organization. The contest of the old with the new world in all departments of life will in all likelihood be the 
great overwhelming question of the coming century, and if Europe wishes to maintain its dominant position in the world or at least its footing of equality with America, it will have to prepare itself betimes for this struggle. This can only be attained by the utmost possible removal of all inter-European fiscal barriers, which limit the market, enhance the expenses of production, and diminish the power of competing in the world-emporium. Further, the feeling of the solidarity of Europe as against the rest of the world must be developed, when the internal European questions of political power and class interest cannot fail to be turned towards higher ends.

During the period of my political activity I earnestly continued my efforts to develop the large business I had called into existence. A change had meanwhile occurred in the management of the Prussian governmenttelegraphs, which had brought me and my firm again into closer connection with it. In the room of Councillor Nottebohm - who could never forgive me for having in my previously mentioned pamphlet traced the entire failure of the Prussian system of underground communications to its real cause, the defective organization of the technical administration - an extremely intelligent officer of engineers, Colonel von Chauvin, • had been named director of the Prussian state telegraphs. The latter renewed the relations with my 
firm, which had been altogether broken off for many years, and made use of its great experience in the telegraphic department to improve the working arrangements of the government-telegraph system, which had remained almost stationary. As at the same time in Russia my old friend and patron. Colonel von Lüders, was again after long illness managing director of the government telegraphs, I conceived the bold plan of calling into existence a special telegraph line between England and India by way of Prussia, Russia, and Persia - the Indo-European line.

The way had already been paved for this plan by the attempts of England to construct a line through the Mediterranean, Asia Minor, and Persia, in the execution of which my brother William had taken an active part. The English Government had in 1862 laid a cable from Bushire in Persia to Kurrachee in India, in the laying of which our electrician Dr. Esselbach had unfortunately met his death. The land line through Asia Minor and Persia joining the cable had also been constructed under English direction by the Turkish and Persian governments, and thus an overland telegraph line to India had actually been called into existence. But the impossibility of really solving the problem in this way soon appeared. The line was usually interrupted, and if it was actually in perfect order, yet the messages often took weeks in transmission, and at last reached their destination in an altogether unintelligible, mutilated state. Theoretically there also existed a second overland connection by 
means of the Prussian and Russian government lines, yet for the transmission of government and commercial messages in the English language this proved almost as unserviceable as the special line through Turkey.

From these experiences it was certain that the great need of a quick and reliable telegraphic communication between England and India could only be satisfied by a line through Prussia, Russia, and Persia planned as a connected whole, and under an undivided management. After I had thoroughly weighed the practicability of such a line with my brothers William and Charles, after moreover William had through his friend, Colonel Bateman-Champain, the constructor of the land line through Asia Minor, secured the benevolent support of the English government and Colonel von Chauvin had given the like assurance on behalf of the Prussian government, our three firms in Berlin, London, and St. Petersburg took the execution of the plan in hand.

The greatest difficulty lay in inducing the Russian government to give permission to a foreign company to construct and work a telegraph line through Russia. This succeeded only after lengthy negotiations, in which our previous achievements both as engineers and as reliable contractors stood us in good stead. The concession finally granted gave us the right of laying and working a double line from the Prussian frontier by way of Kiev, Odessa, Kertch, thence partly under water to Suchum-Kalé on the Caucasian coast, and further via Tiflis to the Persian frontier. 
Prussia herself undertook to construct a double line from the Polish frontier via Berlin to Emden, and to allow this line to be worked by the company we proposed to form. Persia, whither we sent to conclude an agreement our brother Walter and a young relative, George Siemens, then assessor, now first director of the German Bank in Berlin, gave us a concession like Russia for constructing a line of our own from the Russian frontier to Teheran. The completion of the line, already partially constructed from Teheran to India, was undertaken by the English government.

We obtained permission to transfer the concessions granted us to a company domiciled in England, with the condition that the construction and maintenance of the whole line should be entrusted to our firms, and the further proviso that a fifth of the company's shares should always remain in our hands. We thereupon formed an Anglo-German company, with its offices in London, and cannot but regard it as a significant indication of the standing our firm had already attained, that the considerable capital required was subscribed in London' and Berlin at our direct invitation without the intervention of a banker. I may here mention that the Indo-European line still exists as originally constructed and in spite of dangerous competition, caused by a new submarine line laid down by English companies through the Mediterranean and Red Seas, regularly pays a considerable dividend to its shareholders. 
The construction of the line was assigned to our firms in the following manner. The Berlin undertook in conjunction with the St. Petersburg business the management of the construction of the land lines, whilst the London concern was entrusted with the laying of the submarine line in the Black Sea and the delivery of the materials for the construction of the lines. To the Berlin firm moreover was left the design and construction of the necessary telegraphic apparatus. In spite of great and unexpected obstacles the line was completed by the end of 1869 , although unfortunately the already mentioned destruction of the cable along the Caucasian coast resulting from an earthquake, and the inevitably slow replacement of the same by a land line, rendered a regular telegraph service impossible before the following year.

According to the working programme drawn up by us, the messages from London to Calcutta were to be forwarded without any manipulation at the intermediate stations, i. e. by purely mechanical means, in order to preclude loss of time and mutilation by telegraphists in forwarding. For this purpose I constructed for the Indo-European line a special system of apparatus, which completely solved this problem. It naturally excited great astonishment in England, when at the first official experiments London and Calcutta conversed with one another along a line of nearly seven thousand miles as quickly and surely as two neighbouring English telegraph stations. An unexpected difficulty was caused by the 
circumstance that the two wires, especially in dry weather, interfered with one another. This showed itself first in Persia, where the chief engineer of the Berlin firm, Herr Frischen, was occupied in arranging the telegraph service. With the very dry weather prevailing there the two wires were entirely insulated from one another and from the earth, and nevertheless correct Morse writing was received on both receiving instruments of the distant station, when a message was sent on one of the two lines. As the receiving apparatus of the second line at the sending station showed reversed writing, the cause of the disturbances could not but be in the electrostatic charge of the side line, for the currents dynamically induced in it should have given reversed writing at both ends of the second line. This was proved by a series of experiments, which Herr Frischen made in Teheran on my wired instruction. After the canse of the disturbance was ascertained, it could be rendered innocuous by suitable precautions.

This leads me to observe that this double cause of the induced currents arising in neighbouring wires occasions in the working of telephones many disturbances hitherto not altogether intelligible, and still needs thorough investigation. I have subsequently had an opportunity, when my firm laid a sevencored land cable, to institute an instructive experiment in reference to this phenomenon. With the permission of the imperial telegraph administration one of the seven conductors of the cable from Darm- 
stadt to Strassburg, insulated by gutta-percha, was coated with tin-foil, whilst the other six conductors were uncoated. It appeared from the experiments carried out after the laying, that the tin-foil entirely obviated the electrostatic charge between the coated and the other wires, whilst the electro-dynamic induction between them remained quite unchanged. Unfortunately the experiment could not be made with perfectly insulated tin-foil, as such an insulation was not to be attained.

Even before the completion of the Indo-European line our St. Petersburg firm had been entrusted by the Russian government with the construction and the remount of several telegraph lines in the Russian Caucasus, and had for this purpose established a branch in Tiflis, the management of which was committed to my brother Walter. When after the completion of the government works no sufficient occupation could be found for the latter, he proposed to us the purchase of a rich copper mine in the Caucasus at Kedabeg: near Elisabethpol. As mining did not fit into the frame of the business activity of our firms, brother Charles and I gave him privately the not very considerable capital required for the purchase and the working of the mine.

The copper mine of Kedabeg is very old; it is even asserted that it is one of the oldest mines, from which copper was actually extracted in pre-historic 
times. This is rendered probable by its position in the neighbourhood of the large Goktcha lake and of Mount Ararat rising on its western shore, a region, which has indeed often been regarded as the cradle of the human race. A legend even runs that the beautiful valley of the Shamkhor river, which belongs to the forest district of the mine, was the site of the biblical Paradise. At any rate the number of old works, which crown the summit of the metalliferous mountain, testifies to the antiquity of the working of the mine, as does also the occurrence of native copper, and finally the circumstance that extensive pre-historic burial-grounds exist in the vicinity of Kedabeg, in the investigation of which Rudolph Virchow has shown such great interest.

The mine has a beautiful, really paradisiacal environment, with a temperate climate. It lies about 2400 feet above the great Caucasian steppes, which extend from the foot of the spur of the little Cancasus - termed the Goktcha chain - to the Caspian Sea. The working of it, when the primitive pitsinking, subservient to operations on the exposed ore, could no longer be continued, came into the hands of the Greeks, whose slantingly sunk stair-case like shafts, by which they carried up ore and water on their backs, were still in use at the time of brother Walter's taking possession. Operations in accordance with modern principles were commenced by us with very sanguine expectations - as is usually the case with such undertakings - under the direction of a 
young Prussian miner and metallurgist, Dr. Bernoulli. It soon however became apparent that considerable difficulties would have to be overcome and large sums of money spent, before the working conld be remunerative. This is intelligible when one consider's that the mine is situated about 400 miles distant from the Black Sea and at that time was connected with it neither by railways nor regular roads, that all the material required for the mine and the projected copper smeltery, even to the fire-proof bricks. of which there were then none in the Caucasus, had to be brought from Europe, and that for the life of a European colony in this paradisiacal waste, in which earth-caves served for human habitations, all the conditions of civilization had first to be created.

No wonder that the amount of money which the mine swallowed up was great beyond all expectation, so that the question soon became urgent for us brothers, whether we should continue or give up the undertaking. To decide the matter I resolved in the autumn of 1865 to journey myself to the Caucasus, and learn the state of affairs by actual observation. I count this Caucasian journey among the most agreeable memories of my life. I had always felt a secret yearning towards the primitive seats of human culture, and Bodenstedt's glowing descriptions of the luxuriant Caucasian nature had directed this yearning towards the Caucasus and long ago had excited in me the wish to know it. 'There was the further reason for' the journey that I was mentally and bodily very much 
worn by the death of my beloved wife after severe sufferings, and seriously needed a renovating change. Accordingly at the beginning of October 1865 I journeyed by way of Pesth to Basiash, where I embarked on one of the fine Danube steamers for Tchernawoda, in order to go from there via Kustendji to Constantinople. On the ship it was very interesting to me to meet the famous Omer Pacha, then commander-in-chief of the Turkish army. As he exhibited a desire for conversation we soon got acquainted; my Havannah eigars were to his liking and his chibouk, which he ordered his slave repeatedly to fill for me, to mine. Omer Pacha had at one time been a sergeant in the Austrian army, had then gone over to the Turks, had adopted their faith and rapidly risen during the war with Russia. The conquest of Montenegro, which had up to that time been considered impossible, finally carried him to the head of the Turkish army. He was just returning from a prolonged visit to Vienna and Paris. My attempts to get him to relate his warlike exploits he unfortunately always evaded. The recollections of the victories, which he had achieved in Vienna and Paris over the ladies of the ballet and the opera, seemed to him to be more agreeable than those of his warlike deeds. Only with regard to the expected future war of the East against the West of Europe did he express himself, and that in a very sanguine manner. A powerful troop of Turkish horse would, so he thought, overwhelm the West as in former times, and ride down all resistance. For a Turkish 
generalissimo this opinion appeared to me as somewhat childish. He seemed to feel very dependent on public opinion in Turkey, as was manifested on the occasion of a small travelling mishap which befel us. The engine of our vessel had suffered damage in passing the Iron Gate, and we were forced to spend the night in Orsova, that it might be repaired. In consequence we arrived somewhat late at Kustendji, and learnt to our dismay that the steamer, which went from there to Constantinople only twice a week, had not awaited the arrival of our train. The prospect of remaining several days in that dreary place was extremely disagreeable to all of us, especially to the seraskier. A deputation of the passengers headed by me therefore went to him, and begged him to induce the steam-ship company to send a small steamer with us after the one that had already departed. He however declined this for not very intelligible reasons. But afterwards he told me privately, he could not do it on account of his position, for if the steam-ship company had not complied with his request, all the Pachas in the whole empire of Turkey would have said "Haha! Omer Pacha has given an order, but has not been obeyed, haha!" - to which banter he dared not expose himself.

The Bosphorus, the Sea of Marmora, the Fresh Waters, the incomparably beautiful site of Constantinople all this has been so well described and is so familiar to the reader, that I had better be silent about it. In spite of the splendour and grandem of its situation, 
which betrays at the first glance that Nature meant it for the seat of a world-empire, Constantinople with the opposite Pera, looked at from the sea, makes no cheerful or elevating impression. Nobody would say "I have seen Constantinople and can now die!" Probably the dark cypresses, with which the 'Turk adorns his burying-places, rising everywhere in large groups between the houses, give an air of gloom to the aspect of the city in spite of its glorious environment. It may also be the mental reflex of the melancholy history of the place, or the presentiment that the struggle for Constantinople will one day set Europe in flames - in short, the sight of Constantinople excites our admiration indeed, but it does not delight us like that of Naples or many another finely situated city. The prominent architectural structures also, such as the building of the ancient Seraglio at the Golden Horn and even St. Sophia, have nothing stimulating or cheering about them, although they are imposing by reason of their size. The dome of the ancient church of St. Sophia rises mightily indeed above the sea of houses, but one perceives only the dome with its unornamental pillars, looking ungainly at a distance.

The external appearance of St. Sophia has been sacrificed to the beauty of the interior, which is indeed grand and sublime beyond all conception. Never has an architectural structure or any work of art, nay hardly one of the grandest of Nature's beauties, made so overpowering an impression upon me as the dome of St. Sophia seen from within. One altogether forgets 
in looking at it the heavy weight of the roof, which spans the wide square below, and receives an impression as if the dome, floating weightless over the large open space, were a gently curved lace veil, which only touches the rounding with the fine points of the edging. This illusion is produced by the dome resting on a number of short and narrow pillars, between which the dazzling light enters, causing the base of the pillars to appear like lace. I could only with difficulty free myself from the magic, which this floating roof exerted on me, and must confess that thereafter the high vaulted dome of St. Peter's with its heavy superstructure and massive symmetry made no particular impression on me. In St. Peter's one wonders that it is so much greater than it seems, whilst St. Sophia on the contrary appears greater than it is in reality, and thus carries the beholder himself away with admiration of this sublime and by no means oppressive grandeur.

I was pleased during my stay in Constantinople to meet several of the officers, who had already been sent there by Frederick William III. to re-organise the Turkish army, and to find among them some with whom I was acquainted in my military period. These officers had without exception remained Christians and true Germans, whilst the non-commissioned officer's who had gone with them to Constantinople had in part become Mohammedans, and in consequence had already risen to higher grades in the army. One such renegade I met in Trebizond, whither I proceeded in the steamer going to Poti, after tarrying a few days 
in Constantinople. I there visited the Prussian consul, Herr von Herford, who was well known to me in Berlin. He considered it proper that I should pay a visit to the pacha of the place. who was entrusted with the special commission of constructing a high road to Persia. To my question, whether the pacha was inclined to receive us, the answer came, that he was occupied at the moment in his harem inspecting female slaves, who were offered for sale, he would however, after the lapse of an hour, receive us in his ridingground. When the consul presented me to him there, the slender fair-haired man, who was still in his prime of life, seemed somewhat familiar to me. The pacha must have had the like feeling; he scrutinized my face for some time and then asked, if I had been formerly a Prussian officer and in garrison in Magdeburg. When I answered in the affirmative, he asked if I remembered about twenty years ago having had the order to inspect the lightning conductor of a powder magazine placed in the fortifications; he had been the pioneer-sergeant who conducted me there. I had only a dim recollection of this, but could not help wondering at the pacha's excellent memory for faces. When the consul thereupon made mention of the great engineering task, which the pacha had in hand, the latter proposed our taking a ride with him along the new road on some Arab horses he had just purchased, a proposal to which I assented with pleasure. It was a splendid ride that we had on the noble animals at a rapid pace, first on the sea-shore, then in a charming valley with luxuriant 
vegetation on the really beautifully made road. When about an hour had passed the valley narrowed, and the road appeared to make a sharp bend. Then the pacha moderated the pace of his steed. and remarked that the evening was already far advanced and he must return, as he had still some business to attend to. Perhaps the purchase of the slaves was not yet completed, as the consul whispered to me. I was seized however with a great curiosity to see how the country would open out beyond the bend of the valley, and called to the pacha that I should like to take just one glance round the corner, as the beautiful landscape took my fancy exceedingly. But when at full gallop I reached this corner, I found to my great astonishment that the road came to a sudden end. Of course I immediately turned back and in a few minutes caught up my companions. The pacha evidently regarded me with some suspicion, but I was so full of the beautiful view, which I had enjoyed round the turning, that he was soon at his ease again, and took leave of me in very friendly fashion as an old acquaintance. The consul however asked me afterwards, if I had also seen where the road ended - the pacha had pocketed the continuation!

Trebizond is magnificently situated at the foot of the Armenian table-land, with a rather abrupt and broken descent along the entire coast. The beauty of its situation is very considerably enhanced by the exceeding luxuriance of the trees and shrubs, which characterizes the whole region. Perhaps I should 
have been still more enraptured with the town, had not Bodenstedt's enthusiastic descriptions raised my expectations to somewhat too high a pitch. My journey from Trebizond on the following day, favored by the finest weather, lay along the steep beantifully shaped shore. We steamed past Kerasoun, the celebrated cherry city, from whose heights Xenophon's Ten Thousand had beheld the heaving sea and cried "Thalatta!" At Batoum our vessel reached its destination; then we were ferried across in a small coasting steamer to harbourless Poti.

Batoum has indeed only a small but thoroughly safe harbour, easily accessible even in bad weather, and a very fine situation, with wooded mountainous country in the rear; whereas Poti lies at the mouth of the Rion, the Phasis of the ancients, in a wide marshy plain, and possesses no harbour at all, but only a roadstead, which on account of the shallow water must be avoided by vessels in windy weather. Thrice has the Russian government made the costly attempt to construct a break-water, to afford some protection to vessels, but all these attempts have been fruitless. The wicked world asserts that the first mole made of wood was eaten by the bore-worm, the second of cement by the sea-water, and the third built of granite by the generals! Although the last assertion must be regarded as a bad joke, for in reality the immense cost of the stone dike arrested further progress, yet these repeated failures illustrate the necessity felt by Russia to obtain possession of the only available 
harbour of the coast, Batoum, because thereon depended the further development of the whole Caucasian territory. The acquisition of Batoum alone would have been a sufficient equivalent for the cost of the last Turkish war.

I was met at Poti by my brother Walter, in whose company I now continued the journey to Tiflis, which both then and also three years later, when I made a second journey to Kedabeg, was attended with serious inconveniences. One had to go first in a river-steamer up the Rion, as far as Orpiri, a place which was exclusively inhabited by a Russian sect, consisting of beardless men, who had been brought thither from all parts of the Russian empire. Apart from the interesting omnium-gatherum of the most varied nationalities and tongues on board the vessel, the only noticeable thing, which presented itself on the voyage up the Rion, was the sight of a really impenetrable, swampy, primeval forest on both banks of the river.

From Orpiri we drove to Kutais, the ancient Kolchis, which is situated on the slope of a mountain range, connecting the great with the little Caucasus, on the border of the Rion valley, in surroundings pleasing and beautiful.

High above Kutais towers a famous monastery named Gelati, which is considered to be one of the oldest in Christendom, and is said to be built on a site regarded as sacred since the grey dawn of time. I visited it on my second journey, and found myself 
richly rewarded for the toil of a fatiguing ride, which brought me to the monastery situated some thousand feet above the level of the sea. The monastery, now for the most part fallen into ruin, commanding a splendid prospect, is especially celebrated through a small temple, resting on four granite columns, each of which belongs to a peculiar architectural style. This temple is said to date from an extremely remote period, as altogether the age of many architectural remains in the Caucasus is not to be reckoned as in Europe by centuries, but by thousands of years. Although a certain allowance must be made for exaggeration, yet all one sees and hears indicates that the Caucasus is one of the primeval seats of human civilization.

Kutais has now a railway station, and Tiflis is easily reached in a single day from Poti or Batoum. At that time one thought oneself lucky to have at least a new road over the Suram mountains, by which the former very troublesome journey was considerably facilitated. As compensation the Suram pass was extremely picturesque, and afforded the most enchanting views. The underwood of the forest and of the more open parts consists here entirely of rhododendrons and of the arborescent yellow-flowering azaleas of the Caucasus, both plants, which present a most charming spectacle in the flowering season, and fill the air with overpowering perfume. If in addition one imagines bluff walls of rock, rising often almost perpendicularly to the height of several hundred yards, frequently covered from top to bottom with rank old ivy, an 
idea may be formed of the charms of this region. On the other hand the Georgian table-land, upon which one enters after crossing the Suram mountains - the high road to Tiflis following closely the course of the Kur - has no particular beauty; it is stony, often rent by chasms, and poor in vegetation. Still one is reconciled to the sterile environment through the ever-recurring view of the snowy peaks of the great Caucasus, which already from the sea afford a glorious spectacle.

Tiflis, traversed by the river Kur in its deep-cut bed, leans to the north against a precipitous mountainwall, which is doubtless the main cause of the insupportable heat felt in the town during summer. Hence every inhabitant of Tiflis, who can at all afford it, possesses for the hot season a second dwelling placed some thousand feet higher, which he only quits to attend to business affairs in the town. Properly speaking Tiflis is composed of two entirely distinct towns, the upper European, and the lower Asiatic, town, divided from each other by well-defined boundaries. The European Tiflis delights to style itself proudly "The Paris of Asia", or at least claims this title of honour immediately after Calcutta. It has indeed a thoroughly European appearance, being mainly inhabited by Russians and western Europeans. In this part are situated the imperial residence, the theatre, and all the government buildings. The adjoining town on the other hand is in appearance and population purely Asiatic. The reason why Tiflis in very early times 
became a seat of civilization is doubtless to be found in the famous hot springs, which possess an even higher importance for Orientals than for dwellers in the Occident.

From Tiflis our course lay along a tolerably good high-way to Axtapha, where the road to Baku via Elizabethpol branches off from that to the Goktcha Lake and to Persia, and the vast steppes extending to the Caspian Sea begin. On account of the high temperature we chose to continue our journey in the early morning, and ordered the horses for $3 \mathrm{a} . \mathrm{m}$. 'The postmaster however energetically opposed this, as a band of robbers was rendering the country unsafe. The Russian government even to the present day has not succeeded in entirely suppressing brigandage in the Cancasus. The Tartars of the steppes and of the neighbouring mountain regions, in spite of severe punishments, cannot be weaned from it. Just now, in the summer of 1890 , when on the point of making a third journey with my wife and youngest daughter to Kedabeg, I get the news that a band of robbers is carrying on its nefarious practices in the neighbourhood of our mining works and has given occasion for extreme measures against them.

The predatory propensity of the Caucasian tribes, ever manifesting itself afresh, has its root in the habits and sentiments of the population of a country, in which the bearing of arms still forms the man's pride. Plundering is there considered more as a prohibited sport than a crime. As knights in the Middle Ages deemed it compatible with their dignity to snatch 
his wares from the pedlar on the high-road, and to fleece the citizens, so the Caucasian Tartar yearns to roam on his steed as a free man through forests and over steppes, and to take by violence whatever comes in his way. It often occurred at Kedabeg, where the Tartars belong to the best and most reliable workmen, that pitmen, who had laboured industriously for years, and almost without interruption - the Moslem sect of the Shiites to which they belong having only one feast day in the year and no Sunday suddenly disappeared, when they had saved enough money to buy a horse and weapons. Sometimes they returned after a length of time. It was known that in the interval they had been practising brigandage, yet this did not prevent them from becoming excellent workmen again, if they had been unlucky in their predatory occupation, or had lost the taste for it.

The warnings of the postmaster at Axtapha were not strong enough to detain us, but we continued our journey in the cool starry night with fleet horses, and trusted to our good revolvers, which for precaution's sake we held cocked in our hands. My brother Walter however, whom the novelty of the situation did not keep awake like myself, was not able to resist fatigue very long, and soon slept the sleep of the just. Suddenly there rang from the box of our low springless open waggon, on which my brother's servant was seated beside the driver, a loud cry of "Robbers"! At the same time I saw in the gloom a white figure galloping straight towards us. My brother awoke in consequence of 
the shout, and without reflection discharged his revolver at the figure, now close in front of our horses and himself shouting loudly, fortunately without hitting: him. As it soon appeared, it was no robber but an Armenian, who imagined himself pursued by robbers. and had dashed towards us in search of protection. The Armenians generally pass in the Caucasus for very shrewd and smart men of business, who possess little courage, and perhaps for this reason like to equip themselves in as martial a fashion as possible on their journeyings. As it seemed, the gang of robbers, which had terrified our Armenian, existed only in his imagination. His incautiousness however might easily have cost him dear, and the fault would have been entirely his own, as according to the custom of the country it is an understood rule, that one must never approach chance travellers on a journey at a rapid pace.

Shortly after this exciting incident we were delighted by a remarkable natural phenomenon. A brilliant luminous apparition suddenly arose right before us on the horizon of the boundless steppe. It gleamed with a magnificent many-coloured light, was distinguishable from a meteor however by its remaining immovable at the same point of the heavens. We racked our brains as to the cause of the phenomenon, which we could only compare to a parachute rocket with coloured fire. It soon however became weaker, and after a short time shrank to the dimensions of a bright star. It was the rising Venus, which appeared so remarkably magnified and coloured through the mist of the steppes 
and the darkness in which the earth is still veiled in those Southern regions even shortly before sunrise.

We passed the night in the Suabian colony of Annenfeld, which lies or rather lay at the foot of a steep declivity leading to the Kedabeg mine near the Kur, in a very fertile but not salubrious region, for the colonists afterwards abandoned the place, and built for themselves a new village about five hundred feet higher up the slope of the mountain. There exists in the Caucasus a certain number of such Suabian colonies, I believe six or seven, Tiflis also being one of them. They owe their origin to some rigid Lutherans from Suabia, who quitted their fatherland in divers groups in the first decennium of our century, and were desirous of migrating through Austria and Russia to the promised land, where according to the belief of their leaders earthly and heavenly joys awaited them. The Russian government of the time however set great store by the immigration of good German husbandmen into the Caucasus, it therefore stopped the columns, and induced them to send a delegation under escort to Jerusalem, to make previous inquiry whether land really suitable for them was to be had there. When after a rather long interval the delegation returned, it could only advise to discontinue the march to the promised land, and as the Russian government granted the people large and fine tracts of land gratuitously, the Suabians settled there, and always remained the true Suabians they were at the time of the emigration. It comes upon a traveller as 
a great surprise to find in these Suabian settlements the pure and unadulterated old Suabian customs and language. One fancies oneself suddenly transplanted into a village of the Black Forest, such is the appearance of the houses, the streets, and inhabitants of these colonies. It is true I found it difficult to understand their dialect, as I had not then studied it, as is now the case in a measure after twenty years marriage with a Suabian lady, but I learnt from a genuine Suabian that he too only understood it with difficulty, as it was the dialect spoken at the beginning of the century, and not the present one, essentially changed through the influence of time. With the language the people have also retained all their customs and usages, just as they were at the time of the emigration. They are as it were fossilized and inflexibly resist all changes.

It looks however as if this immutability of national custom and language were a general characteristic of the Caucasus, which presents a real mosaic of nations. Besides the larger sharply separated tribes there are a number of quite small ones, which inhabit secluded and almost inaccessible mountain-valleys, and have faithfully preserved both language and customs, which from time immemorial have been altogether different from those of all the neighbouring peoples. Further there exist in the Caucasus numerous Russian colonies, composed of sects which have been transported there from all parts of Russia in the endeavour to preserve the uniformity of the State religion, and are united in 
separate settlements. These too have after more than half a century still retained quite unchanged their language, creed, and customs. The most wide-spread of these sects are those of the Dukhobortsi and Molokani, which like those of the Suabians take their stand on definite and peculiar interpretation of biblical passages. They are excellent workmen, and orderly people when not carried away by fanaticism.

The Molokani are almost without exception artisans, especially cabinet-makers, the Dukhobortsi on the other hand good husbandmen and drivers. The vicinity of a colony of Dukhobortsi has always been of inestimable value to Kedabeg. Once only in the year do the people refuse to work, viz. when their queen proceeds from one colony to another and celebrates religious festivals with them, which however seem to lay great stress on earthly bliss, perhaps only to give the faithful a faint idea of the anticipated and infinitely greater joys hereafter.

From Annenfeld a steep, and not very well-made road leads up to Kedabeg. At the height of about 3000 feet an undulating fertile plain is reached, broken by small mountain ranges, formerly covered by fine forests of oaks, limes, beeches, and other leaf-bearing trees. Since the cessation of the Persian rule, the traces of which are especially recognisable in the frequent ruins of works of irrigation, the woods here, as in most of the elevated plains of the country, have been entirely extirpated; the reason being that, in the hot season when the grass dries up, and likewise in the 
winter when the steppes are covered with snow, the shepherds drive their herds up the mountains to let them browse on the young shoots. For this purpose they simply fell the trees, and let the cattle eat the buds and twigs. In this manner a single herd often annihilates square versts of luxuriant forest. The managers of our foundry have accordingly always experienced the greatest difficulty in preventing these devastating herds from destroying our woods, on the preservation of which smelting is wholly dependent in the absence of coal or other combustible material.

The smelting-works stand by a small mountain brook, which below Kedabeg forces its way abruptly through the ridge separating Kedabeg from the paradisiacally beautiful Shamkhor valley. In the valley where it emerges lie the ruins of a small Armenian fortress, whilst the Shamkhor valley at about the level of Kedabeg conceals an old Armenian monastery, which was then still inhabited by a few monks. At present the aspect of Kedabeg, seen by anyone ascending from the valley, after crossing the last mountain slope and passing an old cemetery on the way, is most surprising. It is the throughly European spectacle of a small picturesquely situated manufacturing town, which presents itself to view, with huge furnaces and large buildings, among them a Christian chapel, a school, and an inn fitted up in European fashion. There is also a railway carried over a lofty viaduct, connecting the branch smelting establishment of Kalakent, some twenty miles off, with Kedabeg and the neighbouring metalliferous 
mountain. This remarkable spectacle of a modern civilized centre in the midst of the wilderness has made Kedabeg a regular place of pilgrimage for the inhabitants of the country as far as the interior of Persia. When I visited it for the first time, the appearance of Kedabeg was certainly a very different one. Except the wooden dwelling-house of the managers, which struck the eye through its position on a commanding height, only a few smelting furnaces and administration buildings were visible. The workmen's dwellings were only distinguishable by wreaths of smoke on the mountain slopes, for they all consisted of caves.

Caves serve in eastern Cancasia almost exclusively for dwellings. They are properly speaking wooden houses, which are built in a pit, and covered over with a layer of earth a yard in thickness, so that the whole looks like a mole-hill. In the middle of the roof a chimney peeps out, which affords an exit for the smoke from the one room, and is at the same time the only admitter of light beside the entrance. For the rest such caves are sometimes quite elegantly made. In a visit, which, in company with my brother and the smelting director, I paid to a neighbouring "prince" — so the larger landed proprietors of the district are called - we were introduced into a tolerably spacious saloon-like room, the floor of which was covered with handsome carpets, whilst the interior partitions were formed of Persian carpets suspended after the manner of side-scenes. Opposite 
the divan was the fire-place, above it the aperture in the roof. Behind the carpets there was a stir of life. and every now and then we heard the voices of women and children. The prince received us with great ceremony and made us sit on the divan, whilst he himself settled in front of it. After a short conversation through the medium of an interpreter, carried on with all the forms of Oriental politeness, we were desirous of departing, but our intention met with very serious resistance. Soon after our entry we had heard the bleating of a sheep, and at once surmised that it was being slaughtered in our honour. In fact the prince signified to us with a very grave countenance, that he hoped we should not so offend him as to quit his abode without having partaken of his hospitality. We were therefore obliged to wait patiently till the "shishlik" was ready, which was prepared before our" very eyes. This preparation took place in the usual very primitive fashion. The flesh of the freshly slaughtered sheep was cut into cubes of about the size of a walnut, which were then arranged on an iron ramrod with disks of fat from the fatty tail of the animal interlarded. Meanwhile a wood-fire was made between two stones, and when only the glowing embers remained of it, the prepared ramrods were laid across the stones and frequently turned. A few minutes after, the meal was ready, and each guest took according to his fancy cubes from the garnished ramrod presented to him. Such a "shishlik", if the sheep is not too old and especially is quite recently 
killed, is very tender and savoury; it always forms the basis of Tartar and Georgian meals, or what we should call in our dinners the "pièce de résistance".

Precisely in the same way as the underground abodes of princes the large underground stables are constructed in the Caucasus. I had already made their acquaintance during the journey at one of the post-stations, where I was reminded by the neighing and trampling of horses that I was walking over a stable. The coolness of the underground habitations in summer and their warmth in winter is extolled, and it has cost the directors of the smelting-works in Kedabeg much trouble to accustom the Asiatic workmen to stone houses. When this at last succeeded with the help of the women, the difficult workman's question was therewith solved. For as the people there have only very few wants there is no reason for their doing much work. When they have earned sufficient money to secure their maintenance for a few weeks they cease to work and take their ease. To cope with this there was only one resource, viz. to accustom the people to needs, the satisfaction of which could only be attained by continuous labour. The handle was afforded by the natural inclination of the female sex for a pleasant family-life and their easily awakened vanity and love of dress. When a few simple workmen's houses had been built, and we had succeeded in quartering therein a few couples, the women soon found pleasure in the greater convenience and comfort of the dwellings. The men also found it an advantage 
not to have incessantly to take measures for securing their roofs from the rain. Further care was taken that the women should be able to procure all sorts of small appliances, which made their life in the house more comfortable, and themselves more attractive to their husbands. They had soon acquired a taste for carpets and mirrors, improved their toilet, in short they experienced wants, for the satisfaction of which the men were now compelled to provide, who in so doing were very well pleased with the change. This excited the envy of the women still dwelling in their caves, and before long there was a general rush for the workmen's dwellings, which of course necessitated the building of houses for all the permanent workmen. I can only urgently advise proceeding on the same lines in our present colonial efforts. The man without wants is hostile to all improvements of civilized life. Only when wants are awakened in him, and he is accustomed to work for their satisfaction, does he form a promising object for social and religious civilizing efforts. To begin with the latter will always only yield illusory results.

When three years later I again visited Kedabeg, I found a quite considerable place of European aspect already arisen out of the Troglodyte settlement. The bulk of the workmen was certainly still nomadic, but this has remained the case even to the present day. These are people who principally come from Persia after the end of the harvest, work industriously in the mine or in the smelting-house, but go further when they have 
earned the necessary money, or when they are wanted at home. There is however now a regular labouring class, which ensures the continuation of the necessary work at all times. The officials of the mine were nearly almost without exception Germans, among them a sprinkling from the Baltic provinces of Russia. The business language has therefore always been German. It is comical to hear Tartars, Persians, and Russians murder the somewhat corrupted German names of implements and operations and even the terms of abuse common among the miners of the Harz.

The mountain, rich in sulphurated copper-ore, is situated in the neighbourhood of Kedabeg, and is connected with it by a so-called haulage-line. Moreover, as has been already mentioned, a narrow-gauge line has been constructed by us, which runs in the river valley of the wild Kalakent brook far into the forests yielding wood and charcoal to the beautifully situated branch smeltery Kalakent, and from there to the wood wharves on the Shamkhor. For many years this mountain railway ensured a supply of combustible material, but carefully as the cleared spaces were replanted in accordance with the principles of forest management, yet at last want of wood threatened to bring the smelting-works to a standstill. However necessity itself is usually the best helper in emergencies: which also held good in this case. We have recently succeeded, I believe for the first time in the world, in replacing coals for smelting by the raw material of petroleum, naphtha, and by masut, the residuum in 
the distillation of petroleum. These combustibles are brought from Baku by the Tiflis line, which has been in existence for some years, to the Shamkhor station at the foot of the mountain. With their help the roasted ore is smelted in large round furnaces, 20 feet in diameter, and worked up into copper. An electric refining establishment at Kalakent transforms the raw copper thus obtained into chemically pure copper, whereby the silver contained in it is obtained as a secondary product. As however it is difficult in winter and during the rainy season to bring masut and naphtha up the mountain from the railway-station to Kedabeg on the impassable roads, a conduit has been constructed of Mannesmann's weldless steel tubes, through which the masut is pumped up the slope about three thousand feet from the plain. I hope personally to see this contrivance in action this very autumn. Furthermore the necessary arrangements have now been completed for transforming the poorer ores, hitherto not paying for the working up into refined copper, according to a new process of my own, by a purely electrical method without the employment of combustible materials. For this purpose large turbines of over a thousand horse-power have to be set up in the neighbouring Shamkhor valley for working the dynamos, which generate the necessary electric current. This current has to be conveyed over the ridge, about 2500 feet high, dividing Kedabeg from Shamkhor, in order to extract and precipitate by the electric current the copper from the powdered ore, at the very foot of 
the metalliferous mountain. When this arrangement, already elaborated in detail theoretically and practically, is ready, there will exist in the distant Caucasus a smeltery, preeminent in a scientific point of view, and able to cope successfully with the disadvantages of its site.

It may easily be imagined that the results obtained by us in Kedabeg would bring us offers of metalliferous property from all sides. Although my brother Charles was as little inclined for further undertakings as I myself, Kedabeg having already given us cares enough, yet we could not always reject the invitation of people of influence to take a look at the proferred beds. When, after the death of my brother Walter, who lost his life very suddenly by a severe fall from his horse, I travelled in the autumn of 1868 for the second time to Kedabeg, I was in this way induced to make two tours in the great Caucasus. One of these from Sukhum-Kalé to Cibelda in particular was of uncommon interest to me.

The Elbrus, 18000 feet high, the loftiest mountain of Europe, if the crest of the high Caucasus range be taken as the natural limit of this part of the globe, is visible in its full height from a few points only, being surrounded by a circle of lofty mountains. The interval, which separates it from this circle, is accessible at a few places only, and is again cut up into different parts by several radial ridges, which render all human intercourse impossible. Among these Cibelda is a natural impregnable fortress, which can be defended by 
a handful of men against whole armies. Long after the rest of the Caucasus had fallen into Russian hands, and the Circassians who would not bend beneath the Russian yoke had emigrated to Turkey, Cibelda remained still unconquered in the possession of its scanty population, forming a tribe by themselves. The Russians had conquered all apparently impregnable fortresses of the Western Caucasus by the construction of roads, which afforded them convenient access into the parts to be subjugated. Cibelda however withstood also the attack by the military road, but hunger and the tempting proposals of the Russian government finally induced them to voluntarily evacuate their fortress, whereupon they likewise resolved to emigrate to Asia Minor.

About a year had elapsed since this emigration, when General Heymann, governor of Sukhum-Kalé, invited my brother Otto, who had stepped into Walter's place in the business and also been appointed German consul in his room, to make an examination of same deposits of copper and silver ore in Cibelda. When with brother Otto and my expert, the recently engaged director Dannenberg, whose introduction to his new office was the main purpose of my journey, I came in September 1868 to Sukhum-Kalé, the general renewed his request, and promised to make our journey to Cibelda as easy and safe as possible. I could not resist the temptation to get in this way to the very centre of the high Caucasus, which, as was said, had never been trodden by the foot of a 
native of Western Europe. A small military expedition for the purpose of taking us to the metallic beds was therefore equipped, under the command of a young Russian captain, who had superintended the exodus of the population of Cibelda.

Sukhum-Kalé, i. e. the "Sukhum fortress", lies very picturesquely on a small rocky bay at the foot of the lofty ring of mountains girding Elbrus. Its environment is entrancingly beautiful, above all by its vegetation, whose luxuriance defies all description. In the place itself my admiration was excited by a long avenue of weeping willows, the height of which vied with that of our loftiest forest-trees, their massy branches hanging down from the dome-like tops to the ground. Unfortunately this splendid avenue fell in the year 1877 a sacrifice to the Russo-Turkish war. The way taken by our well-mounted expedition led immediately behind the town up the valley of a small mountain stream studded throughout with magnificent trees. 'It struck me that the mighty oaks and chestnuts frequently, especially in sunny places, had a perfectly brown envelope, which shut out all sight of green leaves. This was owing to the wild hops, which covered them to the very summits, and gave them this hue through their large ripe umbels. As I knew the great value of the hop, I proposed to General Heymann on our return to have these hops gathered by his soldiers, and sent as samples for examination to Germany. The general did so, but the trial, as I may as well state at once, unfortunately proved unfavourable. It was 
not then known to me that wild hops possess no bitter principle; this is only obtained from the fruit of the female plants when all the male plants are carefully kept apart, which of course is never the case with wild hops.

Our bridle-path took us upwards the whole day through equally beautiful scenery, untouched by human culture. At the same time we were often refreshed by enchanting distant views of the lofty snow-covered mountain-chain, rising gradually before us, and the glittering mirror of the sea, lying at our feet. Towards evening we reached one of the small fortified Russian encampments, whose continual advance on the newly made military roads was the means whereby the Russian forces finally broke the resistance of the brave Circassians.

Next morning we continued our ride at sunrise, and now approached the lofty chain. We had frequently occasion to admire the bold construction of the roads by the Russians; obstacles were there overcome which appeared altogether insurmountable at the first glance. We reached without much difficulty the border of the district already designated by the name of Cibelda, which forms the foreland of the high stronghold of that name. To this there was only a single entrance along a deep cleft in the mountains, at the bottom of which a wild mountain-river took its raging course. The cleft was bordered on the side whence we came by a rocky wall, certainly more than a thousand feet high, almost perpendicular and 
probably over a verst in length. About half way up a horizontal shelf had been formed, which was just broad enough to serve at need as a bridle-path. This path was the only approach to Cibelda; we were therefore obliged to pass it. The officer rode forward after giving us the advice not to look into the chasm, but always at the head of the horse, and let it go quite by itself. In profound silence we successfully reached about the middle of the defile; at the edge of the path some vegetation had settled, whereby the view of the yawning gulf was diverted. Then I suddenly observed that the forepart of the horse of my front man, the officer, was quite low down, and at the same time saw the latter swing himself gently from the saddle to the side of the rocky wall. The horse too did not lose its steadiness, but raised itself again, and continued its way by the side of the officer. I involuntarily considered it advisable to do just as my front man, and also glided from my horse to the side of the rocky wall. When I had successfully passed the dangerous spot, where the officer's horse, misled by the vegetation, had made the false step, I looked with anxiety after my brother who followed me, but perceived to my relief that not only he, but the whole column of riders, had already followed our example. In this manner we all reached in safety the end of the narrow pass, and soon recovered from our toils and alarms by the enjoyment of a good meal, partaken in an enchantingly beautiful moss-covered grotto, open towards the deep and tolerably broad river-valley. 
From this point the path altogether ceased, and it was utterly incomprehensible to me how our guide could find his way in the splendid primeval forest through which we had now to wend. The formation of the ground in the next part of the way was very peculiar. There were imposing undulating elevations with a bend from east to west, perhaps seven hundred feet high, which we had repeatedly to cross. Their southern slopes were adorned with splendid trees, mostly oak, chestnut, and walnut, whose summits formed so perfect a roof that the plague of lianas and other creeping plants was precluded. The trees were of enormous dimensions. It is probable that human hand had never influenced the natural course of their growth; and accordingly old withered giants stood beside the verdant and flourishing, whilst trees of a younger generation overshadowed the mighty trunks lying on the ground, doubtless felled by storms. It often cost a good deal of trouble to evade such a dead tree barring the way, for summit and root formed at their ends effective abatis. Many of these prostrate trees were so thick that a mounted rider was only just able to see beyond them. Now and again they were luckily lying in such a position, that we could pass under them.

An altogether different picture was presented to us, when we had crossed the summit of such a ridge, and had to come down again on its northern slope. Here the sun had not had the power to dry the ground. The whole slope was marshy in spite of its steepness, 
so that the horses' hoofs stuck fast in the tenacious soil, and we were frequently obliged to dismount and assist our horses. Numberless creeping plants also throve here, forcing us to make wide circuits; and the places sought out by us, which on account of too great moisture were free from creepers, bore a vegetation of reed-like plants of such a height that they overtopped horse and rider. Once the ground became so steep that the horses could not proceed. I could then not help admiring the cleverness of our Russians. They sought out a particularly steep and slippery spot, and cautiously let down the horses one by one with ropes attached to their tails, whilst we ourselves slid down without any such check.

At the next ascent I made the discovery that the tail of the Caucasian mountain-horse plays a further important part in difficult mountain-tours. We were obliged to climb up on foot the particularly steep height. to spare the already much fatigued animals, which had necessarily to bring us to our goal before sunset, and I soon found myself at the end of my strength. In my distress it occurred to me to grasp the tail of the horse clambering quite cheerfully beside me up the stony path. That seemed to be a well-known procedure to it; it redoubled its efforts, and I attained without difficulty the crest of the hill, where the officer received me with the applauding exclamation "Caucasian fashion!" When I looked back at my hinder-men, I found them all, to my surprise, also clinging to the tails of their steeds. 
As the sun was going down we reached at last a narrow rocky gate, which forms the entrance into the proper natural fortress of Cibelda. When we had passed it, there spread before us a spectacle of such grandeur and beauty, that it almost overwhelmed me at the first moment. Before us in the clear evening glow lay the mighty Elbrus, covered far down with snow. Right and left beside it a number of further snow-mountains was visible, which developed into a long chain especially on the right. Far below us, partly still illuminated by the sun, lay a rocky river-valley, which bordered the foot of Elbrus, whose steep treeless slope descended towards it in a broad expanse without any visible break. It reminded me somewhat of the view one obtains from Grindelwald over the sun-illumined Alpine chain; only the mighty Elbrus was enthroned in the centre of the picture, as if two Jungfraus were piled on one another.

After we had refreshed ourselves with this astonishing and incomparably beautiful view, we traversed the rather extensive plain, which spread out before us and contained the village of the tribe of the Cibeldians, who had emigrated the year before. It was not easy to advance on the plain, densely overgrown with burdock of more than a man's height, and to find the way to the village. A way broken by bears through the shrubs stood us in good stead. That it had been so made could be inferred from the kernels of the fruit of the cherry-laurels lying about, which form a favourite food for the bears of the region. The 
wooden houses of the large village still stood entire, just as their inhabitants had left them a year ago; only here and there some destruction had been caused by the bears in their search for food.

When we had quartered ourselves, we had first to try to recover a human aspect, for in breaking through the dense vegetation, which had made the former gardens of the village almost impenetrable, every inch of our clothing as of our beards had become fringed with a layer of burs, so that we ourselves looked more like brown bears than human beings. The removal of the burs was an extremely troublesome and in part painful operation.

After a refreshing night's rest in the abandoned dwellings our miner investigated the old copper-pit, which he declared not to be worth working; but even had it been so in the highest degree, its situation would have made any mining operation impossible. My brother Otto and I had meanwhile fully enjoyed the overpowering grandeur and sublime beauty of the environment. By the morning light one perceived still better than in the evening the wild ruggedness of the exposed surface of Elbrus, with its ice-fields and glaciers, to which the lines of the water-courses, rushing down the slopes and glittering in the sunshine, lent a quite peculiar charm. The plateau, on which we stood, descends abruptly to the river-valley, which separates it from Elbrus; on the other sides it is surrounded by high mountains, which, in contrast with Elbrus, presented the most luxuriant green of Caucasian vege- 
tation. A walk round the edge of the plain turned towards the river afforded always new views, entirely different from all the preceding, and of a sublimity and beauty baffling all description.

The return-journey to Sukhum-Kalé we made by the same way as the journey to Cibelda, but in consequence of the previous experience with less difficulty. Unfortunately, I had now to pay my tribute to the dangerous climate of this incomparably beautiful country. Already in the Russian fort, where we again passed the night, I felt ill. 'The young military doctor, who accompanied us, at once perceived that I had caught the dangerous fever of that region, and applied without delay the usual remedy. Before the fever had fully developed I received a powerful dose of quinine, which caused severe singing in the ears and other unpleasant sensations, but brought down the fever to a mild form, so that I was able to complete the journey. The fever in the district of SukhumKalé is a tertian ague: on the third day I therefore had to take a second, somewhat weaker dose, with the direction to take after further three days a third, still weaker one. The fever was thus cut short; I often suffered however in aftertimes of intolerable pains in the side, as the doctor had prognosticated.

In former years I had repeatedly suffered of intermittent fever, which obliged me to take small doses of quinine for several months, thereby serionsly impairing my health. In the Caucasus, where climatic fevers occur often and in the most varied forms, the 
treatment described is always applied with the best results. Certainly there are also fevers in this district so malignant that they end in death on a first attack. The fever-producing regions are indeed as a rule marshy and covered with luxuriant vegetation, but also highly situated dry grass-land often passes for unhealthy. I have in my journeys made the observation, that such regions mostly bear the traces of an old, highly developed civilization, as is indeed also the case in the environment of Rome and in the Dobrudja, which in old times was styled the granary of Rome. Fever breaks ont in those regions with special severity, when the soil is stirred up. The fever-germs must have been gradually formed in the fertile well-manured soil, which was subsequently left unworked for centuries, and excluded from the air by a covering of grass. Malaria accordingly represents nature's penalty for interrupted cultivation of the soil. This, in conjunction with the Caucasian treatment of fever, led me even then to the opinion that climatic fever depends on microscopic organisms, which live in the blood, and whose term of life would coincide with the interval between the attacks of the fever. By the strong dose of quinine shortly before the attack the young emerging brood of these organisms is poisoned. The remarkable fact also, that people, who have long lived in a fever region, are for the most part secure from fever, but lose this immunity when they have passed several years in regions free from it, could, I thought, be explained by the assumption 
that in regions, where the fever-germs are continually being introduced into the body, living beings are formed therein, which feed on these germs, and therefore perish when the source of nutriment is dried up for a long time. - 'This, of course, was only an unproved hypothesis, which was justly only so regarded by my medically trained friends, to whom I communicated it at the time, such as du Bois-Reymond. I have nevertheless been gratified to see the bacteriological researches of eminent scientists taking of late the direction indicated by me a quarter of a century ago.

Our second tour in the great Caucasus had likewise reference to the investigation of a metalliferous property, situated in a very inaccessible region, belonging to a princely family of Georgia. We travelled from Tiflis to Tsarskie-Kolodzy, where our Tiflis branch had petroleum-works, which were again given up after the completion of the railway from Tiflis to Baku. From there our way lay to the wine country Kakhetia, celebrated for the fiery Kakhetian wine. This district lies in the valley of the Alasan, and is separated from the Kur valley by a ridge stretching far into the steppes. From the summit of this ridge we had magnificent views of the Caucasus, which from there presents itself as an unbroken chain of white peaks, reaching from the Black to the Caspian sea.

Kakhetia passes for the primitive land of the vinecultivation, and in the chief place of the country primitive thanksgiving festivals take place, which recall the Roman Saturnalia. High and low then flock to- 
gether from all Georgia to the festive place and offer god Bacchus copious libations of Kakhetian wine, when universal brotherliness is said to be the order of the day. It is also vaunted of Kakhetian wine that it exceedingly gladdens the heart of its persistent drinkers, and those who know the country profess to recognise the inhabitants of Tiflis everywhere by their hilarity.

We accomplished the pleasant and interesting ride through Kakhetia under the guidance of two sons of the princely family, which had invited us to make an inspection of the beds. At the foot of the lofty chain the old prince with other sons joined us. The ancestral seat of the family, in which we passed the night, was remarkable. It consisted of a large wooden house at the foot of the mountains, but yet situated in the plain, which was built on posts some thirteen feet high. A convenient ladder, which was lowered, offered the only possibility of getting into the house. It was a regular pre-historic pile dwelling, the style having survived to our own day in the preservative Caucasian air. In the interior of the house we found a large hall, occupying the whole breadth of the building, in which, along the only wall provided with many windows, a table, over two yards in width, stretched from end to end. This table formed the sole furniture visible in the room, and had to fulfil the most varied purposes. For dinner a carpet of about half the width of the table was laid along its edge, on which the viands and flat cakes were placed. 
The large thin flat cakes served not only for food, but also for table-covers and napkins, as well as for cleaning the table-utensils. For us strangers chairs were brought in. When we had seated ourselves upon them, the old prince and his sons after him sprang upon the table, and crouched opposite us with their bread-cloths. Only we guests were provided with knives and forks, the princes ate in true oriental fashion with their fingers. The meal itself was extremely savoury, especially the fillet of shishlik would have created a sensation in the finest Berlin restaurant. During the meal Kakhetian wine circulated freely in buffalo-horns; it was only rather embarrassing, that custom required the draining of the horn in honour of every person, whose health was proposed. We Europeans, unaccustomed to such copious drinking, could not long stand that. - A second destination of the large table in the hall we got to know at night-time; all the beds, both for us and for the princes, were prepared upon it.

Early in the morning of the following day we set out, and ascended the slope of the great Caucasian chain. Our horses carried us quickly and indefatigably up the rocky way. When it was beginning to get dark, we were almost at our destination and bivouacked on a splendid ridge, at the junction of two mountainstreams. Under the protecting roof of gigantic trees we encamped at a spot, which afforded a wide view over Kakhetia extended at our feet and the mountaindistrict lying beyond. With surprising skill the prince's 
satellites erected a hut of twigs over our campingplace, leaving the view over the plain free, and made it so comfortable that it would not have been possible to have rested more agreeably. Then the meal was rapidly prepared, which we consumed in a recumbent position. After that the princes and their attendants reclined in front of us, and began a national drinkingbout with a kind of mulled wine of generous Kakhetian growth. In the course of this each of the princes drank my own and my brother's health with some doubtless very flattering words, expecting that thereupon we should also empty our horns. The princes spoke Georgian only, an interpreter translated for us into Russian what they said. No one of those present understood our German answers, a circumstance of which my frolicsome brother Otto took a somewhat dangerous advantage by delivering the replies, which I left to him, in extremely polite fashion indeed as regards voice, tone, and gesture, but with a verbal parody of the whole scene, which assuredly would have been cut short by dagger-stabs, if his words had been understood, and if we had not taken pains to give a good colour to them by grave and respectful countenances.

When, on the following morning, we had happily slept off our little debauch in the refreshing mountainair, without any unpleasant after-effects, we inspected the lode, which was certainly a rich one, but not yet opened up, and owing to the troublesome access to it offered insuperable obstacles to profitable working. 
After we had arrived at this conclusion, the returnjourney was immediately commenced.

At sunset we again arrived at the pile-built palace and spent another night under its hospitable roof. The next morning we took leave of our princes, and rode back through the valley of Kakhetia, with the intention of travelling across the steppe direct to Kedabeg. As robbers were infesting the neighbourhood, the chief of the district gave us a body-guard composed of men. who themselves were not free from suspicion of the robber's trade. Placed under their friendly protection, we travelled with perfect safety according to the custom of the country.

The crossing of the broad and rapidly flowing Kur: whose left bank we reached at noon, was attended with some difficulty. We found a single small boat there, which could only carry a few persons, but discovered no oars, which moreover with the rapid current would not have been of much use. The mode of crossing employed by our guides was very interesting, and I commend it to the Postmaster General for his description of the postal service in primitive times. The two best horses were driven into the water until their feet no longer touched the bottom. Then two Tartars in the boat laid hold of their tails and had themselves together with the boat and a few passengers carried over the stream by the swimming horses. When after depositing the passengers the boat had been brought back in the same manner, they carried over a second batch with other horses, and thus it 
went on, till only the Tartars remained. Finally these took their horses into the water and let themselves be carried over clinging to their tails.

I and my brother had remained to the last with our somewhat dubious escort on the left bank of the river. Our protectors squatted suspiciously together, and kept throwing glances at us, which we did not altogether like. Cigars, which we offered them, they proudly refused - because, as we found out afterwards, being bigoted Shiites they were not allowed to take anything from the hands of unbelieving dogs. It appeared therefore advisable to show to the fellows that we were sufficiently armed for defence. We set up a board, that had floated down stream, as mark, and shot at it with our revolvers, in the use of which we were well practised. Every shot hit the board at long range without much aiming. That interested our companions very much, who themselves tried with their long beautifully polished flintlock guns to hit our mark, but did not always succeed. Then came their sheik and gave me to understand by signs, that I should show him my revolver, and lay it on the ground, as he dared not take anything from my own hand. This was a critical moment, but on Otto's advice I determined to comply with his request and put down the revolver. The sheik took it up, looked at it on all sides, and showed it with a shake of his head to his companions. After that he gave it me back with gestures of thanks, and henceforward our friendship was sealed. Distrust of the fulfilment of the sacred 
law of hospitality may become very dangerous with these people, on the other hand the case is extremely rare that the confidence of the guest is betrayed. It has certainly occurred that a guest has been hospitably entertained and safely escorted to the boundary of the district, and then shot down on alien ground, but that is not considered to be proper. After crossing the Kur we reached Kedabeg without further adventures.

In all our tours in the mountains we had had occasion to admire the cleverness and endurance of the small Caucasian mountain-horses. Indefatigably and without tripping they clamber with their riders up and down the steepest mountain-paths; without them the broken and often fissured mountainous country could hardly be traversed. It is regarded in the Cancasus as safer to make difficult mountain-journeys on horseback than on foot. That there are also exceptions to this rule I experienced personally on my second visit to Kedabeg. The autumn weather, always bright and beautiful even up to December, changed with unexpected suddenness to rainy weather with a slight fall of snow. We were just then proceeding to visit the Shamkhor valley, and made use of the somewhat troublesome bridle-path thither, which runs by the side of the wild Kalakent brook as far as Shamkhor. When however it began to snow more heavily, we found it advisable to turn back before the path had been quite snowed over. It was astonishing with what accuracy our horses were able to find the mountain-path, already considerably covered 
with snow, which was close beside the deeply cut river-bed, and always selected the particular parts where there was a sure footing. I was riding immediately behind my brother Otto, when I noticed, that just at a dangerous spot hard by the edge of the bank, here descending perpendicularly several yards, a stone became loose under the weight of his horse. A moment afterwards my horse trod upon the same stone, which thereby was entirely loosened and caused my fall. I only remember having heard the cry of the succeeding riders, and that I was then standing upright in the river-bed, my horse beside me. According to the statement of my companions the horse fell over sideways with me and then came on its feet. It was at any rate a marvellously lucky escape.

Of the homeward journeys, for which both times I chose the route via Constantinople, the first in particular was rich in singular experiences. The fine weather lasted till the middle of December; only after we had left Kedabeg did it change, and on the Rion we encountered a fearful storm. With great difficulty we reached Poti, but there we learnt that the steamship, which was to convey us further, had already passed, as an embarkation in such weather was impossible. We, namely the whole company that had arrived in the river-steamer, were thus forced to take refuge for a full week in the only so-called hotel of the place, a most dreary abode. This, I may say, was the most unpleasant week of my whole life. A violent storm raged the whole night, not only outside 
but also in my room. I repeatedly got up to examine the windows and doors, but found them all closed. The next morning however I saw my room full of snow-flakes, and discovered that they had penetrated through rifts in the floor. On account of the marshy ground the houses in Poti are built on piles, which explains the marvel of a snow-fall in a closed room. The stormy weather lasted without intermission several days, and what rendered my stay particularly disagreeable was, that I had caught a severe inflammation of the connective tissue of one of my eyes. This painful inflammation, alleviated by no medical aid, the confined inn-parlour filled with people of all classes and nationalities, moreover bad provisions and a total absence of any kind of attendance, made my life there simply intolerable.

At last the eagerly longed-for steamer came in sight, and in spite of the heavy sea succeeded in taking aboard myself and three other travelling companions. The passage was very stormy as far as the entrance to the Bosphorus, and put our seaworthiness to a severe test. All four of us however stood it to the great astonishment of the captain. Among the party was a Russian general, consul in Messina, and, as I discovered later, father of a very charming daughter, now the wife of my friend Professor Dohrn in Naples; further a young Russian diplomatist, who subsequently filled important posts, and finally an extremely original Austrian foundry proprietor, who never allowed his pipe to go out, except when eating 
or sleeping. As also the captain was a well-instructed clever man, the unusually long voyage passed nevertheless quickly and agreeably for us, in spite of wind and waves.

In Trebizond, where we anchored for a few hours, I again met with one of my many small mishaps. I had taken a walk on the plateau above the town, to enjoy once again the splendid prospect, and was returning by the fine new road, which on the side descending abruptly to the sea was entirely unsecured by railings, when I met a large drove of donkeys laden with sacks of corn. I inconsiderately stepped to the unrailed side towards the sea, to let the drove pass. That was all right at first, but gradually the drove became denser, and finally occupied the whole width of the road. No pushing and no beating availed, the beasts could not, if they had tried, make room for me. The attempt to jump on to one of the donkeys failed, I was compelled to make way for them, and fell down the steep stone-work into mud and among bushes, whereby luckily the force of the considerable fall was somewhat lessened. After I had found that I had got off without serious injuries, I worked myself laboriously out of the thorns and nettles, and only after long and many vain endeavours was able to scramble up again to the road. Fortunately I found a small pond at the top, in which I could wash myself and clothes. The still powerful sun effected the drying with tolerable rapidity, and thus I could manage to go through the town without 
exciting attention and reach the steamer, which fortunately had awaited my return.

On the further journey the strong wind grew into a storm, so that the captain began to fear for his old ship, and sought refuge in the harbour of Sinope. Twice on the following days he attempted to continue the voyage, but was each time driven back into the safe port. Thus I had the opportunity of experiencing by personal observation the correctness of the designation of the Black Sea as the "inhospitable", which the ancient Greeks had given it.

In the harbour of Pera I found an Austrian Lloyd steamer just ready to start for Trieste, where we landed on New Year's eve safely and without let and hindrance. On the way, in Syra and Corfu, we had been suspected of being plague-stricken and compelled to hoist the notorious yellow flag, because the cholera was raging in Egypt.

With these two Caucasian journeys I regard my travelling period proper as closed, for the European journeys of to-day in comfortable railway-carriages or post-chaises are only to be called pleasure trips. Also the third journey to Kedabeg, for which I am now preparing, to take my final leave of the Caucasus, will hardly be anything else. 
Harzburg, June 1891.

Still full of the fresh impressions and pleasant reminiscences of my third Caucasian journey, which I made, as proposed, last autumn with my wife and daughter, I shall resume my narrative by giving an account of it. This tour, undertaken with all imaginable comfort as a pleasure trip, will thus stand out in strong relief to my first two journeys to Kedabeg.

We travelled in the middle of September from Berlin to Odessa. There of course I did not omit to visit the station of the Indo-European line, and held a telegraphic conversation with the manager of the company in London, Mr. Andrews. Such a direct telegraphic intercommunication after a long journey has always something uncommonly interesting, I might almost say elevating, about it. The victory of the human mind over inert matter is thereby brought immediately and forcibly home to us.

From Odessa we proceeded to the Crimea, my acquaintance with which had been hitherto confined to the places of call of the steamers running between Odessa and Poti. We decided to leave the vessel at Sebastopol, and travel by road to Yalta. The drive 
was favoured by splendid weather, and permitted us to admire at leisure the magnificent coast-scenery, which stretches from the steep slopes of the southern tableland of the Crimea to the sea. Much reminded us here of the Riviera, indeed there were many points of the Crimean coast, whose superiority we were obliged to allow. The situation of the country-palaces Livadia and Alupka, belonging to the Imperial family, as well as that of many another residence of Russian notables, is beautiful in the extreme. There was wanting, however, the fresh pulsating life of the Riviera, which so considerably heightens the charms of its scenery and climate. The climate of the southern Crimean coast is pleasant and free from fever, and the means of communication, becoming continually more rapid and convenient, will doubtless therefore soon bring it a great accession of tourists. On the other hand it is impossible to speak as favourably of the climate of the incomparably more beautiful and grander eastern side of the high Caucasus, for there almost everywhere malignant intermittent fevers prevail, and the prospect of medical science overcoming this great plague of humanity appears as yet to be very slight.

It was an interesting coincidence, that the glad tidings of the conquest of one of the greatest scourges of mankind, consumption, by the discoveries of Koch, reached me in this third journey to the Caucasus, in the very regions where so many years before the theory had obtruded.itself upon me of the excitation of climatic fever by microscopic life in the blood. 
The cure was said to be effected by introducing into the patient's system a poison, produced by the phthisis-producing bacteria themselves, in the shape of their vital products. The reported results left no doubt as to the correctness of the fact, and we Germans heard with pride on all sides our countryman lauded as a benefactor of humanity. But the assumption of Koch, that the vital products of the disease-causing bacilli constitute the powerful deadly poison, even then excited my doubts. One could well imagine that this self-induced poisoning might check the development of the bacilli in the parts of the body occupied by them - thus affording an explanation of the remarkable phenomenon, that not every infectious disease leads to the death of the person assailed by it - but it appeared inconceivable to me that an infinitesimal quantity of such poisonous vital products of a limited number of bacilli should produce in another body the powerful effects observed. A vital process alone could accomplish this, in which not the substance of the germs introduced, but the vital conditions maintaining them, and the time required for their increase, are the chief factors in the case. The question as to the origin of these germs, which develop a life hostile to the bacilli whence they arise, appears to me only to admit of a plausible answer, if one supposes the living beings producing the disease to be themselves subject to infectious diseases, whereby they on their part are checked in their vitality and finally killed. It would of course follow that life, animal as well as vegetable; 
is not restricted to the objects revealed by our microscopes, but that there are living beings related as regards size to the microbes and bacteria, as these are to us. No scientific objection can be raised to this hypothesis, for the dimensions of molecules are in any case immeasurably less than living structures of even so low an order. The mysterious process of spontaneous fission, the succeeding immunity, the otherwise inexplicable effect of the introduction of vital products of the disease-causing bacilli into the circulation of a body affected by the same disease, would on this assumption be the obvious consequences of the infection of the disease-generators themselves, and the problem of the future would be, how to produce such an infection, and bring it to the speediest issue, since indeed these secondary disease-generators themselves might also be subject to rapidly developing infectious diseases through microbes of a still lower order. If however not the vital products, but the secondary disease-carriers, of the bacilli are the curative means, the bacilli must first become diseased, before their substance can act remedially. Perhaps herein lies the reason of the unsatisfactory action of Koch's tuberculine, and the present suggestion may be of service in the further investigation of this subject, which is of such vast importance to all mankind.

In Tiflis we met my brother Charles, who accompanied us on our further journey to Kedabeg and Baku and back to St. Petersburg. Dr. Hammacher, member of the Imperial Diet, who had formed one 
of our party from the first, also remained our faithful travelling companion as far as St. Petersburg. Tiflis appeared to me not to be much altered externally in the 23 years, which had expired since my last visit, but it had lost its former aristocratic air, and can no longer boast to-day of being the Asiatic Paris. The town was formerly not only a grand-ducal residence, but also the seat of the native Georgian nobility, which especially in winter took the lead in the social gatherings of Tiflis. All that is now changed. No Grand-Duke resides any longer in Tiflis, and even the Georgian aristocracy has almost entirely disappeared. A quarter of a century ago the town was still Georgian, and the best houses as well as the administration of the town were in Georgian hands. But even then the Armenian nationality began to spread, and gradually the land and landed property passed into Armenian hands. In earlier, warlike times, the brave and vigorous Georgians maintained their possessions and their social position against the crafty and pushing Armenians. That ceased however, when under Russian rule permanent peace and an orderly state of affairs were established. From that time the Armenian element came to the front, and the Georgian was compelled to make way for it. Now well-nigh the whole property of the town is in Armenian hands. The proud figures of the Georgians in their dazzling accoutrements have disappeared from the streets of Tiflis, the Armenian dwells in their palaces and is master of the situation.

The intermixture of nationalities in the Cauca- 
sus offers excellent material for studying the influence of the intercourse of specifically different races of men in warlike as in peaceful times. It is surprising that in the Caucasus the Jewish element has not proved capable of coping with the Armenian. It is true Jews are to be found there in tolerable numbers, but they are all drivers, and have the reputation of being rough fellows, always on the look-out for an opportunity of displaying their superior physical strength. Trading they have altogether renounced. The Russians are mostly clever and shrewd men of business, can however, as they themselves admit, not hold their own against Armenians and Greeks. The reputation for greatest longheadedness in all business-relations in the Caucasus as in the whole East is enjoyed by the Greek, yet the Armenians, when they are banded together, carry off the palm from the Greek, who always trafficks on his own account.

When after a few days we continued our journey by railway, we found at the foot of the Kedabeg tableland a new railway-station, Dalliar, from which the road to Kedabeg runs by way of the new Suabian colony Annenfeld. Here we found in course of construction the already mentioned conduit, through which the naphtha brought by rail from Baku to Dalliar was to be pumped up to Kedabeg about three thousand feet. The operations, as regards both the laying the tubes and the arrangements of the pumping station, were proceeding well, but we had to abandon the hope of seeing the completed work in action before the beginning of winter. 
Our drive from Dalliar to Kedabeg formed a genuine Oriental spectacle to the great delight of the ladies. The Beys of the neighbourhood had heard of the arrival of the owners of the wonderful mine, and did not omit to greet us festively with their dependants, and escort us to Kedabeg. This party was continually renewed and increased on the road nearly twentyfive English miles long. They swarmed round our carriage on their fleet Caucasian mountain-horses, mostly at a wild gallop, up hill and down dale, and afforded, in their Caucasian costume and accoutrements, an extremely attractive spectacle. In chasing past the men performed the most daring, break-neck feats of horsemanship, at the same time firing off their guns, so that our approach produced the impression rather of a warlike encounter than of a peaceful reception. Near Kedabeg the entire population of the place, together with the miners and smelters, joined the procession. In the house of our head manager, Mr. Bolton, we were received by the ladies of his household, and lodged most comfortably. During our stay we derived some benefit from the visit, which had taken place a few weeks before, of the young Crown Prince of Italy, who, attended by the Russian grandees of the Caucasus, had visited our mine and smeltery. For the reception and entertainment of these guests unusual arrangements had of course been made, which had especially included provision for a comfortable descent into the mine and the procuring of an improvised saloon-carriage for our railway. We re- 
peatedly made use of the latter in our visits to the outwork Kalakent and the Shamkhor on the picturesque line, carried often over perilous abysses.

Despite the often rather annoying fumes from the works we fully enjoyed in glorious autumn weather the charms of the beautiful environs of Kedabeg. Among the special delights must be reckoned a bearhunt, which we attended in the so-called paradise. This name is borne by a small table-land, bordered by the rivers Shamkhor and Kalakent, which is splendidly situated and adorned with many wild fruit-trees. The great abundance of fruit in the autumn attracts the bears of the neighbourhood, and the officials of our mine had often instituted successful bear-hunts in this season.

We passed the night in the branch smelting house Kalakent, and at sunrise repaired for the chase to the neighbouring mountains, which during the night had been surrounded by our forest-keeper with a chain of beaters. It was a wonderfully fine morning, and the noiseless march on the lonely hunting paths in constant expectation of the bears was not without a charm. After a rather long time, passed in intense expectation, we heard in the far distance the call of the beaters resounding from the summit of the slope, the base of which we held. Nothing else was heard in the general stillness except the falling of the autumn leaves, a sound, with which hitherto I had only made acquaintance in novels. I was posted on a narrow mountain-path between brother Charles and Dr. Hammacher. 
My weapon was a rifle with two barrels, one charged with ball, the other with small shot. Similarly defective was the equipment of my companions in the chase. Gradually the clamour of the beaters came nearer, but of bears nothing was to be seen or heard. Suddenly the forest-keeper called our attention by signs to a slight rustle in front of us, and immediately delivered a shot in the direction indicated. The bear slunk away to the left without being hit. A shot delivered by Dr. Hammacher took just as little effect. Then on the other side of me cracked a shot by my brother and immediately after a second. I thought my chance was gone of getting a shot, when all at once close beside me a large brown female bear, accompanied by a cub, crossed the clearing. I delivered my ball-charge at the bear, when the cub fell on its knees with terror, which made me believe I had hit the latter. The mother and her young however ran quietly down the mountain. Every one of us of course thought he had shot his bear, and the district was eagerly searched for the wounded. Traces of blood were indeed discovered, but neither then nor afterwards was anything to be seen of our wounded bears. In the further beating up too no bear was slain, only one more in fact came to view and that close to the beaters. These and the bear seem to have been equally terrified and fled in opposite directions, the beaters calling out as if in their death-agony.

One of the finest tours in the further environs of Kedabeg embraces the valley of the Kalakent brook 
above Kalakent itself to the summit of the mountain enclosing the large Goktsha lake. From the summit of the pass the immense lake is seen in the foreground, whilst the chains of the Armenian highlands form the background of the splendid panorama. My travelling companions, who had not shrunk from the severe ride necessary to reach this commanding eminence, had the good fortune to enjoy a perfectly clear prospect, the snowcaps of the great and little Ararat standing out with perfect distinctness.

After brother Charles and I had had our full delight in the great progress which our remote possession had made in the last years, and our companions had exhausted the charms of the surrounding forest-clad hills in extensive rides, we continued our journey to Baku, to pay a visit to the ancient sacred perpetual fires, and to make acquaintance with the sources of the modern fire-bringer, donor at any rate of far greater blessings, petroleum. We had quite special reasons for so doing, since it was owing to naphtha, the mother of petroleum, that we found Kedabeg in brisk and hopeful activity.

The route lay by way of Elisabethpol, the government town of Kedabeg, in the neighbourhood of which is situated Helenendorf, the largest of the Suabian settlements. When the worthy Suabians heard of our presence in Kedabeg, they sent their mayor with an invitation to us, to visit Helenendorf likewise. We of course accepted it, and on our arrival in Elisabethpol were received by a deputation of the peasants, and 
were quickly driven to the village a few miles off. There the whole community took pains to show attention to their German countrymen and especially to their Suabian countrywoman. We had to inspect the church, the school, and the waterworks, and took genuine delight in the old thoroughly German orderliness, which has defied all opposing influences of the country and climate. Helenendorf is the most flourishing and prosperous of all the Suabian settlements in the Caucasus, and owes this in part, no doubt, to the healthy climate and the favourable situation in a fine, mountainous, and well-watered region. To its inhabitants the merit is due of having introduced German conveyances into the Caucasus. Recently the colony has taken to the cultivation of the vine, and turns out excellent products of the native grapes by the application of modern methods.

The railroad-journey through the monotonous steppe of Elisabethpol to Baku does not offer much that is noticeable. The vegetation is very scanty, with the exception of places which lie by water-courses or have artificial irrigation, of which certainly for the most part only a few traces have remained. It is not the land which has value in such regions, but the water which can be conveyed to it. Progressive culture will in this respect be still able to do much, but even if the rivers were deprived of all their water to fertilize the fields, this would benefit only a small part of the great steppes of Russia. The needful amount of rain is wanting. Whether this has ab- 
solutely diminished within historic times, which might be concluded from many phenomena, or whether only its distribution has become different, cannot as yet be decided.

The astonishingly large number of wooden prospecttowers thirty to fifty feet high in the wholly flat region, which afforded but the smallest prospect, is explained by the circumstance, that the inhabitants in the worst fever-season pass the nights in these tower's to escape the fever.

A peculiar spectacle was afforded towards the end of the journey by a whole town of similar wooden towers, standing much higher still, apparently close to one another, which crowned the summit of a near mountain-range. More exact observation through a telescope revealed that they were high boring-towers, such as are wont to be erected for deep borings. This was the district of the famous naphtha wells. Thence the oil is conveyed for refining through numerous conduits to the neighbouring "black town" of Baku or rather to its newer part, which contains the numerous petroleum distilleries. It is remarkable that borings in the closest proximity, sometimes more than a thousand feet deep, often yield altogether different results. Frequently, on reaching the petroleum stratum, a fountain arises, from which the naphtha spurts up to a height exceeding a hundred feet. A hollow is then quickly made in the neighbouring soil, to collect the gushing naphtha. The yield of the well however soon diminishes. After a few weeks it is wont no longer 
to "strike", as they say in Baku, and the naphtha must now be pumped up from the bottom of the boring. The boring-towers are accordingly left standing, in order to be used subsequently as pumpingtowers. It is hard to explain, how it happens, that at a very slight distance from a boring, where the elasticity of the gases, which at first pressed up the petroleum, is already quite absorbed, a new and strong fountain can arise, as it must be assumed, that all the wells spring from a single stratum of naphtha. Altogether the origin of petroleum is still veiled in darkness, and therefore one cannot say whether it will maintain a permanent place in the field of human civilization. How large an influence the naphtha wells of Baku already exercise on the life and industry of Russia is obvious from the long rows of reservoir waggons for the transport of petroleum and masut, which are met with on all the Russian railway-lines. As the forests of Russia have almost everywhere been largely cleared, and coal is only found in quantities on the Don, masut and raw petroleum have quickly attained great importance as cheap and easily transportable fuel. A large part of the Russian locomotives and riversteamers are even now heated by petroleum, and for many branches of Russian industry this has proved a great help in need, as was the case in the working of our Kedabeg copper-mine.

The old town of Baku is beautifully situated on the abruptly rising shore of the Caspian Sea. Besides the district of the naphtha wells with the very 
modernized everlasting fires, the "black town", and a number of interesting architectural remains of the time when it was the residence of the Persian Khans, the town offers few attractions for the stranger. But with favourable weather he may procure himself the pleasure of setting the Caspian Sea on fire, if he makes an excursion in an iron steamer to a place not far from the coast, where inflammable gases rise from the sea-bottom. In calm weather these may be ignited and then.form a sea of flame around the ship, often lasting a considerable time.

We made the return-journey by land via Moscow and St. Petersburg. In crossing the great Caucasus we traversed grandly beautiful wild mountain-valleys in the depression at the foot of Kasbek. But if one wishes thoroughly to enjoy their beauty it is better to travel in the reverse direction, for the wild Terek valley, which forms the northern slope of the mountains, is so quickly traversed in descending, that one has hardly time to enjoy the charms of the surrounding country; a further drawback being the disagreeably abrupt bendings of the otherwise marvellous road, when passed over at full speed. From Vladi-Kavkas, the commencement of the Russian railway-network, we travelled to Moscow in three days without break of journey. Unfortunately, owing to the cloudy weather of the first day, the fine views of the great Caucasus, especially the towering Elbrus, escaped us. The numerous cairns on both sides of the road were highly interesting. They prove that for long periods of time a relatively high 
civilization prevailed on the northern slopes of the Caucasus, and it is here perhaps that we must look for the centre of origin and rallying point of the tribes, which have at different times deluged Europe.

I resist the temptation to describe Moscow, and will only refer to the feeling experienced there of being thoroughly in Russia, i. e. on the border-land of European and Asiatic culture. One has this sensation more keenly if, like ourselves on this occasion, one comes from Asia and therefore brings a vivid feeling for Asiatic life and doings. This is hardly to be put into definite words. "In Asia", said one of my fair travelling companions, "dirt and rags are not repulsive, here they certainly are". This is in fact quite characteristic of the transition from Asiatic to European civilization. The Asiatic in spite of dirt and rags always exhibits a certain degree of manly dignity, which the European in rags invariably lacks.

The Russian proper, i. e. the native of Great Russia, forms a true transition between Asiatics and Europeans, and is therefore the proper and successful carrier of European civilization eastward. The converse way, of which the Panslavist Russians now often dream, the renewal of the "rotten West" by the native energy of Asia, has certainly no great likelihood of being ever realized. It can indeed not be denied that there lies a danger for the development of EuropeoAmerican civilization in the fact, that Europe has become the voluntary teacher of Asia in procuring and utilizing the instruments of power, which the former 
owes to its technical progress. With the great capacity of the Asiatics for imitation and for utilizing their acquirements, and with the ever advancing art of depriving distance of its dividing power by improving the means of communication, undoubtedly our little Europe might be exposed to a new invasion from Asia subversive of culture, but the first annihilating blow would then light on the intervening countries, especially Russia, as history has indeed already repeatedly shown. For the rest this danger can only arise, when the scientific and technical progress of Europe comes to a standstill, so that it loses the great start in its technical development, which most surely protects its civilization from every inroad of barbarian nations. Only internal suicidal conflicts could lead to that, for in mental power and inventive faculties the peoples of Europe are far superior to the Asiatics and will doubtless remain so in the future.

In Moscow it was already intensely cold, in St. Petersburg sledging had actually begun and the Neva was covered with drifting ice, so that after a short stay we continued our journey and could still enjoy for a while the milder climate of home.

As in the two past years I have come here to Harzburg at the end of June, in order to devote a few weeks to recording these reminiscences, and do not intend to leave before I have come to the end of them. I have repeatedly tried in Charlottenburg 
to continue my task, but I have not succeeded there, where everything is pressing forward, in persistently looking backward. For it is habit which puts the strongest shackles on us. I have never been able entirely to put aside the thoughts and plans, which were just then occupying my mind, and this has frequently spoiled my enjoyment of the present, to which I could never wholly devote myself except in passing moments. But on the other hand such a thought-life, partly spent in dreamy speculations, partly in strenuous aspirations, also affords great enjoyment. It sometimes even perhaps brings us the purest and sublimest joys of which man is capable. When a law of nature, hitherto hovering darkly before the mind, all at once clearly emerges from the enveloping mist, when the key to a long vainly sought mechanical combination is found, when the missing link of a chain of thought is happily inserted, this affords the discoverer the elevating feeling of an achieved mental victory, which alone richly compensates him for all the pains of the struggle and exalts him for the moment to a higher stage of existence. Certainly the ecstacy does not generally last long. Self-criticism usually soon discovers a dark spot in the discovery, which renders its truth dubious or at least narrowly restricts it. It exposes a fallacy in which one has been entangled or, as is unfortunately almost the rule, it leads to the perception that only an old friend has been met with in a new dress. Only when strict examination has left a sound kernel does the regular hard labour 
begin of elaborating and completing the invention, and then the struggle for its introduction into scientific and mechanical life, in which most men are ultimately ruined. Discovering and inventing bring's therefore hours of supreme delight, but also hours of the greatest disappointment, and of hard fruitless work. The public commonly notices only the few cases in which successful inventors have hit, almost accidentally, upon a useful idea, and by making the most of it, have attained without much labour to fame and affluence, or the class of acquisitive invention-hunters, who make it their life-task to seek for technical applications of well-known things and to secure the benefit of them by patents. But these are not the inventors who open for the development of mankind new paths, which will presumably conduct it to more perfect and happier conditions of life, but those who - either in the quiet of scholarly seclusion, or in the bustle of technical activity - devote their whole being and thought to this development for its own sake. Whether, by correct judgment and use of the opportunities of practical life, inventions lead to the accumulation of wealth or not, frequently depends on chance. Unfortunately however the instances of success possess great attraction and have called forth a host of inventors, who plunge into discovery and invention without the necessary knowledge and without self-criticism and thus are mostly ruined. I have ever regarded it as a duty to turn such deluded inventors from the dangerous path which they had entered upon, and this 
has always cost me much time and trouble. Unhappily my efforts have rarely been attended with success, and only complete failure and the bitterest self-inflicted distress occasionally brings these inventors to a perception of their errors.

There are specially two inventive ideas, which have misled and frequently also ruined innumerable people, otherwise fairly gifted and even remarkably clever in their own sphere of activity. These are the inventions of so-called perpetual motion i. e. of a self-acting work-performing machine, and that of the flying-machine and the manageable balloon. One might have thought, that the knowledge of the law of the conservation of energy had already so far penetrated the popular mind, that creating force out of nothing would have come to be considered as contrary to nature as the production of matter, but it seems that generations must always pass away before a new fundamental truth is universally regarded as such. If a man is once possessed by the unhappy delusion, that he has found the way to construct working machines by mechanical combinations alone, he has become the victim of a generally incurable mental ailment, which defies all teaching, and even the most painful experience. Almost the like holds good of the endeavours to construct flying-machines and manageable air-balloons. The problem itself is indeed for every mind possessing a slight mechanical training a very simple one. It is indubitable that we can construct flying-machines according to the pattern of flying 
animals, if only the fundamental condition be fulfilled, which consists in this, that we have machines as light and powerful as the motor muscles of flying animals and which do not require a much larger supply of combustible material. When such a machine is invented, every skilled mechanician can make a flying-machine. The inventors however always begin at the wrong end, and invent flying mechanisms without having the power for moving them. Still worse is it with the manageable air-ships. The problem of their construction has been long ago solved in principle, for every air-balloon may, in perfectly calm weather, be slowly propelled in any direction by a suitable mechanism applied in the car. Progress however can only be slow, because in the first place power-machines of sufficient lightness are still wanting to drive the voluminous balloon at greater speed through the air or against the wind, and secondly because the material of the balloon would not stand a strong counter-pressure of the atmosphere, even if we possessed such machines. The oblong form, which the inventors give the balloon, in order that it may better cleave the air, increases its weight with equal volume and is therefore worthless. The like holds good of the application of inclined planes, which are intended to facilitate the supporting of the weight.

Besides these two problems there are a number of others on which inventors squander time and money by failing to perceive that the means for carrying them out are not yet at the disposal of applied science. 
After these digressions I resume the thread of my narrative with my retirement from political activity.

The war of 1866 had removed the obstacles which opposed the longed-for unity of Germany, and had at the same time restored internal peace in Prussia. A new support was thereby given to the national idea, and the hitherto vague tentative efforts, as it were, of German patriots now obtained a firm foundation and definite direction. It is true, the Main boundary still divided Germany into a Northern and a Southern half, but no one doubted that its removal was only a question of time, if it was not rigidly fixed by external force. That France would make that attempt appeared certain, but there was a growing confidence, that Germany would successfully stand this trial also. As a consequence of this great revolution of popular sentiment there resulted the general endeavour to consolidate quickly what had been attained, to strengthen the feeling of solidarity of North and South despite the Main boundary and to prepare for the coming struggle. This buoyant feeling was evidenced by increased activity in all departments of life, nor did it fail to react on our business affairs. Magneto-electric mineexploders, electric range-finders, electric apparatus for steering unmanned boats, furnished with explosives, against hostile ships, as well as numerous improvements of military telegraphy, were the off-spring of this stirring time.

I will here only give a detailed account of a non-military invention of this time, as it has become 
the foundation of a new and important branch of industry, and has exerted and still continues to exert a stimulating and transforming influence in all departments of technology, I mean the invention of the dynamo-electric machine.

As early as the autumn of 1866 , when I was intent on perfecting electric exploding apparatus with the help of my cylindrical inductor, the question occupied my mind, whether it would not be possible by suitable employment of the so-called extra-current, to considerably intensify the induction-current. It became clear to me, that an electro-magnetic machine, whose working power is very much enfeebled by the induced currents arising in its coils, because these induced currents considerably diminish the efficiency of the source of electricity, might conversely strengthen the force of the latter, if it were forcibly turned in the opposite direction by an external force. This could not fail to be the case, because the direction of the induced currents was at the same time reversed by the reversed movement. In fact, experiments confirmed this theory, and it appeared that there always remains sufficient magnetism in the fixed electro-magnets of a suitably contrived electro-magnetic machine to produce the most surprising effects by gradually strengthening the current generated by the reversed rotation.

This was the discovery and first application of the dynamo-electric principle underlying all dynamoelectric machines. The first problem, which was 
thereby practically solved, was the construction of an effective electric exploding apparatus without steel magnets, and such exploding apparatus is still in general use at the present day. The Berlin physicists, among them Magnus, Dove, Riess, du Bois-Reymond, were extremely surprised, when I laid before them in December 1866 such an exploding inductor, and showed, that a small electro-magnetic machine without battery and permanent magnets, which could be turned in one direction without effort and with any velocity, offered an almost insuperable resistance when turned in the opposite direction, and at the same time produced an electric current of such strength, that its wire-coils became quickly heated. Professor Magnus immediately offered to lay a description of my invention before the Berlin Academy of Sciences, but, on account of the Christmas holidays, this could only be done in the following year, on the $17^{\text {th }}$ of January 1867.

The priority of my application of the dynamoelectric principle was afterwards impugned in various quarters, when its enormous importance came to be seen in its further development. At first, Professor Wheatstone was almost universally recognised in England as simultaneous inventor, because at a sitting of the Royal Society on the $15^{\text {th }}$ of February 1867, at which my brother William produced my apparatus, he immediately exhibited a similar apparatus, which was only distinguishable from mine by the wire-coils of the fixed electro-magnet being differently disposed in their relation to those of the rotating cylindrical magnet. 
Next, Mr. Varley came forward with the assertion, that already in the early part of the autumn of 1866 he had given orders to a mechanician for just such an apparatus, and also subsequently handed in a "provisional specification" of the same. My first complete theoretical establishment of the principle in the printed 'Transactions of the Berlin Academy, and its previous practical elucidation, have however finally been taken to be decisive in my favour. The name given by me to the apparatus "dynamo-electric machine" has also become general, although frequently corrupted in practice into "the dynamo".

Already in my communication to the Berlin Academy, I had pointed out that technical science was now in possession of appliances capable of producing electric currents of any desired tension and strength by the expenditure of energy, and that this would prove of great importance for many of its branches. In fact large machines of the kind were immediately constructed by my firm, one of which was exhibited at the Paris Universal Exhibition of 1867, whilst a second was employed in the summer of the same year by the military authorities for electric lighting experiments in Berlin. These experiments proved indeed quite satisfactory, with the drawback, however, of the wire-coils of the armatures rapidly becoming so hot, that the electric light produced could only be allowed for a short time without interruption. The machine exhibited in Paris was never actually put to the test, as there were no appliances for the transmission of 
force in the space allotted to my firm, and the jury, to which I myself belonged, did not subject the exhibits of their nembers, which were "hors concours", to any trial. All the greater was the sensation caused by an imitation of my machine exhibited by an English mechanician, which produced from time to time a small electric light. It was considered a sufficient recognition that the order of the Legion of Honour was awarded to me at the close of the exhibition.

When at a later time the dynamo-machine, after considerable improvement, especially by the introduction of Pacinotti's ring and Hefner's coiling system, had received the most extensive application in practice, and both mathematicians and engineers had developed its theory, it seemed almost self-evident and hardly to be called an invention, that one should arrive by merely reversing the rotation of an electro-magnetic machine at the dynamo-electric machine. Against this it may be said, that the most obvious inventions, of primary importance, are commonly made very late, and in the most round-about way. For the rest it would not have been easy to have arrived by accident at the discovery of the dynamo-electric principle, because electro-magnetic machines only "excite", i. e. spontaneously strengthen their electro-magnetism on reversing the rotation, when their dimensions and the disposition of the coils are perfectly correct.

To this period also belongs my invention of the alcoholmeter, which very successfully solved an extremely difficult problem, and accordingly excited 
much attention at the time. The problem consisted in constructing an apparatus to register continuously and automatically the quantity of absolute alcohol contained in the spirit flowing through it. My apparatus solved this problem so completely, that it indicated the quantity of alcohol, reduced to the customary normal temperature, as accurately as could be determined by the most exact scientific measurements. The Russian government has employed this apparatus for almost a quarter of a century in levying the high tax, which is imposed on the production of spirit, and many other European states have also subsequently adopted it for the same purpose. Apart from a few important practical improvements due to my cousin Louis Siemens, the apparatus is still supplied in the original form as a regular article of manufacture by a factory specially erected for the purpose in Charlottenburg. No imitation has hitherto been successful anywhere, although the apparatus is unprotected by a patent.

The dimensions, which the firm of Siemens and Halske gradually attained, of course required a corresponding organization of the management and the help of able technical and administrative assistants. The friend of my youth, William Meyer, who filled the post of chief engineer and confidential clerk from the year 1855 , had, by his considerable organizing talent, not only rendered valuable service to the Berlin firm, but also to its branches in London, St. Petersburg, 
and Vienna. Unfortunately he fell ill of a serious disorder after eleven years activity in the business, and died after prolonged sickness, deeply lamented by me as a personal friend and faithful co-worker.

Not long afterwards, in the year 1868, my old friend and partner Halske retired from the firm. The favourable development of the business - this will hardly appear credible to many at first sight — was the determining reason for his taking this step. The explanation lies in Halske's singularly constituted nature. He took great pleasure in the faultless productions of his clever hand, as well as in everything that he could entirely overlook and control. Our common activity was thoroughly satisfactory for both parties. Halske always gladly adopted my constructive plans and designs, which with remarkable mechanical tact he at once most distinctly apprehended, and to which he often first gave their full value by his practical skill. At the same time Halske was a clear-headed cautious man of business, and him alone have I to thank for the good business results of the first years. The case altered however, when the business increased and could no longer be managed by us two alone. Halske regarded it as a desecration of his cherished establishment that strangers should have rank and rule in it. Even the installation of a book-keeper gave him pain. He could never get over it that the wellorganized concern should exist and work without him. Finally, when the designs and undertakings of the firm became so large that he could no more overlook 
them, he felt no longer satisfied, and resolved to retire, in order to devote his whole activity to the administration of the city of Berlin, which afforded him personal satisfaction. Halske remained a dear and faithful friend to me till his death, which occurred last year, and always, even to the last, retained a lively interest in the establishment of which he was joint-founder. His only son takes to-day an active part in the management of the present business as confidential clerk.

As Meyer's successor we appointed the former director of the Hanoverian telegraph system, Herr Karl Frischen, who after the annexation of Hanover passed over into the service of the North German Confederation, and had for several years filled the office formerly held by Meyer as chief telegraph engineer of the Government telegraphs. The business gained in Herr Frischen an eminent technical worker, who had already distinguished himself by many original inventions. Further it was now of great advantage to the firm, that excellent departmental managers and constructors had been formed among its junior assistants, who had received their training in the firm. I shall - only mention Herr von Hefner-Alteneck, whose achievements as head of our construction-office have earned for him a world-wide reputation.

Supported by such able coadjutors I was able more and more to confine myself to the general management of the business, and to leave with full confidence the details to our assistants. In this way I obtained greater 
leisure to occupy myself with scientific and such social problems as I had particularly at heart.

My domestic life underwent a complete transformation through my second marriage, which took place on the $13^{\text {th }}$ of July 1869, with Antonie Siemens, a distant relative, the only child of the meritorious, and in agricultural technology well-known, professor Carl Siemens in Hohenheim near Stuttgart. I have often jokingly said in after-dinner speeches and the like, that this marriage with a Suabian lady should be looked upon as a political act, as the Main line was bound to be bridged, and this could best be done by as many alliances of affection as possible being concluded between North and South, which must then of themselves soon be followed by political ones. Whether my patriotism was not considerably influenced by the amiable qualities of the fair Suabian herself, who has again brought warm sunshine into my somewhat gloomy and laborious life, I shall not here more closely enquire.

When on the $30^{\text {th }}$ of July 1870 the news arrived by telegraph in Charlottenburg that the Emperor Napoleon had crossed the German frontier at Saarbrück and the fateful war between Germany and France had actually begun, my wife presented me with a little daughter, to be followed two years later by a son. I gave our daughter the name Hertha, in pursuance of a vow to give her this name, if the German warship so called, which the French fleet were chasing in all waters, escaped capture. My four elder children 
were in Heligoland at the time of the declaration of war, and had to flee as speedily as possible with the whole troop of visitors, in order not to be prevented from returning by the blockade. The telegram of my eldest son, then sixteen, from Cuxhaven may pass as a sample of the deep emotion and courage that had taken possession of all Germany - "I must join too", words that happily could not be translated into action, as before the completed seventeenth year no one is accepted in the Prussian army.

The war with France, like that of 1866 , was speedily carried to a victorious issue for Germany, after a struggle of tremendous proportions. The joyful consciousness, that Germans from all parts for the first time in the course of their history fought and conquered side by side under the same flag, made the heavy sacrifices, with which the gloriously achieved victories had to be purchased, appear more endurable, and lightened the profound mourning and misery, which the war entailed. It was a glorious and elevating time, which has left impressions never to be effaced on all who lived through it; and coming generations will assuredly never suffer the feeling of devout gratitude to die out, which the nation owes to the great leaders who put an end to its ignominious discords, and made it united and powerful.

Although I had entirely renounced political activity after the year 1866 , I still continued to take the 
greatest interest in public affairs. One question, to which I had long before paid particular attention, was that of patent-right. It had long become clear to me that one of the greatest obstacles to the free and independent development of German industry lay in the lack of protection for inventions. It is true that in Prussia, as also in the other large states of Germany, patents were granted for inventions, but the grant entirely depended on the good pleasure of the authorities and lasted at the most only for three years. Even for this short time they afforded only a very unsatisfactory protection against imitation, for it rarely paid to take out patents in all the states belonging to the Zollverein, since every state applied its own test of originality, and indeed strictly speaking it was impossible, as many of the smaller states did not grant patents at all. The consequence was that inventors, as a matter of course, sought in the first instance to turn their inventions to account in foreign countries, especially England, France, and the United States. The youthful German industry was therefore altogether thrown upon the imitation of foreign productions, and thereby indirectly still more strengthened the preference of the German public for foreign manufactures by only dealing in imitations, and these for the most part also under a foreign flag.

As to the worthlessness of the old Prussian patents there could not be two opinions. Indeed they were as a rule only applied for in order to obtain a certificate that an invention had actually been made. Further- 
more, the then dominant thoroughgoing Free Trade party regarded the patenting of inventions as a relic of the old monopoly rights, and incompatible with the principles of Free Trade. In this sense a circular letter was sent in the summer of 1863 by the Prussian Minister of Commerce to all the chambers of commerce of the state, in which the uselessness, nay even injuriousness of the patent system was set forth and finally the question propounded, whether the time had not come to abolish it entirely. This led me to draw up a memorial to the Berlin Chamber of Commerce, the council of Berlin merchants, which adopted the diametrically opposite point of view, to set forth the necessity and utility of a patent-law for the promotion of the industry of the country, and to sketch the outlines of a rational patent-law.

My detailed statement was approved by the Council, although the latter consisted of very pronounced free traders. It was unanimously adopted as the opinion of the Chamber of Commerce, and at the same time communicated to the other chambers of commerce of the state. Of the latter those, which had not yet sent in a reply assenting to the abolition of patents, expressed their sympathy with the Berlin decision, and as a consequence the proposal for abolition was abandoned.

This favourable result afterwards encouraged me to initiate a serious agitation for the introduction of an imperial patent-law, on the basis proposed by me. I sent a circular to a considerable number of men, 
who I supposed would have a special interest in the matter, and asked them to form a "Patent Protection Union", with the object of procuring a rational German patent-law. The call was generally responded to, and a short time after the Union was called into existence under my presidency. I remember with pleasure the stimulating debates of this Union, to which eminent legal authorities such as Professor Klostermann, Mayor André, and Dr. Rosenthal belonged. The final result of the discussions was the draft of a patent-law, which essentially rested on the foundation laid by me in my statement of 1863 . This consisted of a preliminary inquiry in regard to the novelty of the invention and subsequent public exhibition of the specification, thereby affording an opportunity for objections to the grant; further the grant of the patent for the term of fifteen years, with yearly increasing impost and complete publication of the patent granted; finally establishment of a patenttribunal, which on application could always declare the nullity of the patent, if the originality of the invention was afterwards successfully disputed.

These principles gradually gained approval with the public also, and even the Free Trade party of the most rigid principles was quieted by the economic basis of the proposal, which consisted in the protection appearing as a reward for the immediate and complete publication of the invention, whereby the new ideas underlying the patented invention became themselves industrial common property, and might even bear 
fruit in other fields. It took however a long time before the imperial government resolved to take legislative action in the matter. I fancy that a memorial, which as president of the Patent Protection Union I addressed to the imperial Chancellor, had a considerable influence on the decision for the promulgation of an imperial patent-law. In this memorial I laid stress on the inferior condition and the slight estimation of German industry, its productions being everywhere styled "cheap and nasty"; and at the same time I pointed out that a new firm bond for the young German empire would be created, if thousands of manufacturers and engineers from all parts of the country could find in the institutions of the empire the long desired protection for their intellectual property.

In the year 1876 a meeting of manufacturers as well as of administrative officials and judges was called together from all Germany, which made the draft of the Patent Protection Union the definite basis of their deliberations. The bill resulting from these deliberations was adopted by the Reichstag with a few modifications, and has very materially contributed to strengthen German industry, and procure respect for its productions both at home and abroad. Our industry has since been on the best way to lose in almost all its branches the stigma of "cheap and nasty", which Professor" Reuleaux rightly gave to its productions at the Philadelphia Exhibition in 1876. 
I will now take up my account of the development of the businesses established by us from the point where I described the changes, which our London house had to go through after the unsuccessful cable undertakings between Spain and Algeria in the year 1864. The firm of Siemens Brothers, from that time separated from the Berlin business, had quickly and regularly developed under brother William's direction, both as manufacturing and contracting concern. As William had also at the same time great success in the engineering business carried on by him privately, and his time and energies were thereby very much taken up, the desire arose at the end of the sixties that brother Charles should undertake the special management of the London telegraph business. Charles consented, as since the expiration of the Russian maintenance contracts he no longer found any considerable sphere of activity in Russia.

Halske's resolution to retire from the Berlin firm was taken about the same time, and we three brothers decided accordingly upon an entire reform of the business-connection of our different firms. A joint business was formed which embraced them all. Each firm retained its independence as regards administration and financial methods, its profit and loss account however was carried over to the joint business, of which we three brothers were the sole proprietors and partners. The St. Petersburg concern was placed under an able manager, whilst Charles went to England to undertake the special management of the London firm. 
How splendidly the London house, now named "Siemens Brothers", prospered in the immediately following period has been described at length in the above-mentioned book of Dr. Pole on my brother' William. I therefore confine myself here to some remarks on my own and my brother Charles's personal cooperation.

When in the year 1869 Charles transferred his residence to London, the factory at Charlton was already in full work as a mechanical workshop for the construction of electric apparatus of every kind; a cablesheathing shop was also combined with it, in which important cables had already been manufactured. The principle employed by me in the testings of the English Government cables, that the permanence of a cable could only be assured, if it were tested at all stages of its manufacture with scientific thoroughness and accuracy, had borne good fruit, and the system of cable testings, then elaborated, has answered admirably well in the sequel.

The remarkable success of the Malta-Alexandria line, which we tested according to this system for the English Government, had considerably raised our technical reputation in England, and perhaps for this reason the only factory in England, which then turned out wires coated with seamless gutta-percha according to my method, threw difficulties in the way of supplying the purified gutta-percha which we ordered from it. We accordingly resolved to establish our own gutta-percha factory, and accomplished this with complete success. 
In this manner we were enabled ourselves to undertake great cable-layings, and thereby to break down the monopoly of the great cable-ring which had meanwhile been formed, and whose purpose was to monopolize the whole submarine telegraphy. In reality my brothers succeeded in calling a Company into existence, which entrusted to us the production and the laying of an independent direct cable between Ireland and the United States. The requisite capital was subscribed on the Continent, as the English market was closed to us by the overwhelming competition.

Brother William shewed his great constructive ingenuity by designing a large steam - ship expressly destined for the laying of cables, which was christened by us "Faraday". Brother Charles undertook the command of it on laying the cable. I considered Charles specially fitted for this task, as he was cool and deliberate, besides being a good observer and resolute in action. I myself was not to be deterred from sailing in the Faraday, freighted with the deepsea cable, to the starting point of the laying, Ballinskellig Bay, on the west coast of Ireland, and there undertaking the direction of the operations of the landstation during the laying.

It was tolerably favourable weather, and everything went well. The difficult abrupt descent of the Irish coast into deep water was successfully got over, and according to the electrical testings the state of the cable was faultless. Then suddenly there occurred a small defect in the insulation, so small that only extremely 
sensitive instruments, such as we were employing, could have detected it. According to previous cable-laying practice, this defect would have been allowed to pass, as it was without any influence on the signalling. But we wished to lay down a perfectly faultless cable, and determined therefore to take the cable up again to the point of the fault, which must be immediately behind the ship. This indeed went off well in spite of the great depth of 18,000 feet, as was continuously telegraphed to us from the ship. Suddenly however the scale of our galvanometer flew out of the field of sight, - the cable was broken! Broken at a depth, from which to fish up the end again appeared quite impossible.

It was a hard blow, which threatened our personal reputation as well as our business credit. The intelligence spread through all England in the same hour, and was received with very different feelings. Nobody believed in the possibility of recovering a detached piece of cable from so great a depth, and even brother William advised by telegraph to abandon the paid-out cable, and to recommence the laying. I was however convinced that Charles would not return without having made the attempt to pick the cable up, and calmly watched the continual fluctuations of the scale of the galvanometer to detect any signs pointing to the movement of the cable-end by the search-anchor. Such indications indeed frequently occurred, without having further consequences, and two anxious days passed without any news from the ship. All at once 
a violent mirror-vibration! The end of the copperwire must be in metallic contact. Then for several hours feeble regular twitching of the reflected image of the scale, from which I inferred a jerky lifting of the cable-end by the grapnel. However succeeding quiet for hours together caused hope to sink again. Then once more strong mirror-vibration produced by a current from the ship, which was greeted with reiterated hurrahs by the workers at the "station. The incredible had been realised. From a depth exceeding the height of Mont Blanc the cable had been found by a single operation, and what is more, had been brought up to the surface unbroken. Many favourable circumstances must have combined to make this possible. Grood sandy sea-bottom, fine weather, suitable appliances for seeking and lifting the cable, and a good manageable ship with a skilful captain, happily concurred, and made the apparently impossible possible with the help of much luck and self-confidence. Brother Charles, however, confessed to me afterwards that during the uninterrupted lowering of the grapnel, which took seven hours; to reach the sea-bottom, giving him for the first time a clear idea of the known depth, he had lost all hope of success and was himself astounded when it came.

After successful removal of the fault and re-establishment of connection with the land the laying was continued for some days without disturbance. Then the ship reported rough weather, and soon after a small fault again occurred in the cable, which was 
left however till reaching shallow water off Newfoundland, in order to seek and remove it when the weather was more favourable. The picking up proved however to be very difficult, as the sea-bottom was rocky and the weather persistently bad. Much cable was thereby lost, and the Faraday was obliged to return to England without finishing her task, to ship fresh cable and coals. Yet even the following expedition led only to the more accurate localization, but not to the removal of the fault, and a third attempt was necessary, in order to render the cable communication perfectly faultless.

This first transatlantic cable-laying of ours was not only exceedingly instructive for us, but in point of fact led for the first time to the complete clear apprehension and mastery of cable-layings in deep water. We had shown, that even in unfavourable weather and at a bad time of year cables can be laid and repaired, and that too in very deep seas and with a single, but well-constructed and sufficiently large ship. The loss of cable, which we had had in the repairings, was attributed by brother Charles to the unsuitableness of the construction of the cable, which was identical with that adopted for the first successful transatlantic cable. For diminishing the specific gravity of the cable steel wires had been used for the covering and protection of the conductor, surrounded with hemp or jute. On a strong pull these twisted the cable and produced kinks in the cable on the bottom of the ocean, which very much impeded or altogether 
prevented the taking up again. In accordance with Charles's suggestion we afterwards used only a closed steel-wire sheathing and thereby removed all the difficulties, which so considerably hampered our first deep sea laying.

On the further technical improvements in the method of laying cables in deep water, to which the preceding enterprise led us, I cannot here enlarge. I will only mention that my theory, propounded on laying the Cagliari-Bona cable in 1857, has held its ground very well. As already mentioned, I have further developed and mathematically treated this theory in an essay laid before the Berlin Academy of Sciences and the Society of Telegraph Engineers and Electricians in London, and believe that it may now be regarded as fairly settled.

The laying of this our first transatlantic cable brought us brothers many exciting incidents, one of which occurred at a very unfavourable moment and profoundly agitated me.

I had been elected in the year 1874 by the Royal Academy of Sciences in Berlin one of its ordinary members, an honour which hitherto had only fallen to the lot of professed savans, and on the day fixed for the purpose I was about to give my prescribed inaugural address at a special meeting of the Academy, when on leaving the house I received a telegraphic message from London to the effect, that according to a cablegram the Faraday had been crushed by icebergs and had gone down with all hands on board. 
It required no slight self-control on my part, oppressed as I was by this terrible intelligence, still to deliver my address, which did not admit of postponement. Only a few intimate friends had perceived my violent emotion. Certainly I had hopes from the first moment, that it was only a "love-token" of our opponents, to cause this dread intelligence to be concocted in America, whence it was telegraphed. And indeed it soon turned out to be a baseless fiction. How the story originated could never be found out, and after the lapse of several anxious days the Faraday was reported safe and sound from Halifax. It had for a considerable time been detained at sea by a thick fog.

The successful completion of the American cable raised the London firm at a stroke to a far higher level of English business-life than it had occupied hitherto. The testing of the electric properties of the cable by the highest authority in this department, Sir William Thomson, had proved that it was entirely faultless and possessed a very high signalling capacity. It was of great importance that the cable ring; which had been formed under Sir John Pender's auspices, was now broken through. It is true the attempt was made to restore it by subsequently admitting to the ring the cable laid by us. This however was to our advantage, for there was soon formed another, and this time a French, company, which gave orders to our firm to lay an independent cable. After a short time this also was purchased by the Globe, as the cable ring was called, but this led to American capital being 
attracted to cable telegraphy. Brother William received in the year 1881 a cablegram, in which the well-known railway-king Mr. Gould ordered a double cable to America, which was to be constructed entirely like the last laid by us - the French so-called PouyerQuertier cable. It is a sign of the credit, which our firm enjoyed also on the other side of the ocean, that Mr. Gould declined to receive a representative to conclude the contract, "as he had perfect confidence in us," and confirmed this by the remittance of a large instalment. This was the more noteworthy, as Mr. Gould is well known in America as a very cautious and keen man of business, and it was a matter of some millions. At any rate, however, he had correctly speculated, for his unlimited confidence constrained my brothers to propose the most favourable conditions possible and to execute the work in the very best fashion. The Gould cables after some competitive contests were also united with the Globe, but it was America that again broke through the monopoly. In the year 1884 the well-known Americans, Mackay and Bennett, gave orders to Siemens Brothers for two cables between the English coast and New York, which were faultlessly manufactured and laid within a year, and have up till now maintained their independence of the cable ring.

These six transatlantic cables have all been laid by the "Faraday", which proved a most satisfactory ship for cable-laying, and as such has served as a model for the competing firms. The double screw with axes inclined to one another, which was first 
employed in it, gave to the great ship of 5000 tons a degree of mobility hitherto unattained, which made it possible to carry out cable-laying and repairing work in every season and even in unfavourable weather.

Brother Charles had already returned in the year 1880 to St. Petersburg, after the London firm had at his instigation been transformed into a private limited liability company. In the year 1883 brother William was, alas, torn from us and his untiring activity by a quite unexpected and sudden death. Herr Löffler, an official of many years standing, was installed as managing director of the London firm, and has been recently succeeded by a younger member of the family, Mr. Alexander Siemens.

My appointment as ordinary member of the Berlin Academy of Sciences was not only very honourable in itself for the favoured individual, who did not belong to the class of professional savans, it also had a profound influence on my later life. As my friend du BoisReymond, who acknowledged my inaugural address as presiding secretary of the Academy, rightly pointed out, I belonged by natural endowment and inclination in a far higher degree to science than to practice. Scientific research was my first, my early love, and it has retained my affection to the advanced age, which I now - I can hardly say - enjoy. At the same time I have certainly always felt the impulse to make scientific attainments useful for practical life. 
I expressed that in my inaugural address, when I enlarged on the theme that science does not exist for its own sake, merely to satisfy the thirst for knowledge of the limited number of its votaries, but that its office is to increase the treasures of knowledge and power of the human race, and thereby to raise mankind to a higher level of civilization. It was noteworthy that friend $\mathrm{du}$ Bois in his reply to my address bade me at the end welcome "into the circle of the Academy, which only pursues science for its own sake". In very truth scientific investigation must not be means to an end. The German savant has always been justly distinguished by this, that he pursues science on its own account, for the satisfaction of his thirst for knowledge, and in this sense I have always been able to reckon myself more to the savans than to the engineers, since the prospective profit has either not at all, or only in special cases, guided me in the choice of my scientific work. The entrance into the narrow circle of distinguished men of science could not therefore but elevate me in a high degree and spur me to scientific activity. Moreover the statutes of the Academy exerted a beneficial constraint upon me. Every member must in rotation give a lecture, which is then printed in its Transactions. As it was very disagreeable to evade this obligation, it compelled me to complete and publish researches, which under other circumstances I should perhaps have postponed in favour of others seemingly more interesting, or have left altogether unfinished. Whilst therefore before my 
reception into the Academy I seldom got so far as the publication of a piece of scientific work, and usually contented myself with the enlargement of my own knowledge - not without subsequent vexation, if my results were discovered and then made public by others - I was now obliged every year to finish and publish one or two contributions. To this state of things is also to be ascribed the circumstance that in my academical lectures I dealt less with matters of my special department, electrical technology, than with subjects of general scientific interest. They were partly detached thoughts and reflections, jotted down in the course of my life, which were now brought together and scientifically worked up, partly novel phenomena, which aroused my particular interest and called for special investigation. I shall once more return to these purely scientific publications at the close of these reminiscences.

Although since my reception into the Academy I had been far more occupied than heretofore with purely scientific problems, which stood in no relation to my business calling, I did not omit to continue to devote the needful time to the latter also. The superior management of the Berlin firm, and the technical work connected with it, usually claimed my whole working time during the day. The difficulty of my task was much augmented by the increasingly multifarious character of the firm's operations, and the great dimensions they had assumed; and although able coadjutors relieved me of a con- 
siderable portion of the burden, yet there still remained for me much arduous and unceasing work.

It had very early become clear to me that a satisfactory development of the continually growing firm must depend on securing the hearty spontaneous co-operation of all the workers for the furtherance of its interests. To attain this it seemed to me essential that all who belonged to the firm should share in the profits according to their performances. As my brothers acceded to my view this principle came to be adopted in all our establishments. Arrangements to that end were settled at the celebration of the twenty-fifth anniversary of the original Berlin firm in the autumn of 1872 . We then * determined that a considerable portion of the yearly profits should regularly be set aside for allowing a percentage to officials proportionate to their salaries and bonuses to workmen, and as a reserve fund for necessitous cases. Moreover we presented the collective body of workers with a capital-stock of $£ 9000$ for an old age and invalid fund, the firm agreeing to pay every year to the account of the managers of the fund, chosen directly by those interested, fifteen shillings for each workman and thirty shillings for each official, who had served in the business uninterruptedly for a twelvemonth.

These arrangements have worked remarkably well during the nearly twenty years of their existence. Officials and workmen regard themselves as a permanent part of the firm and identify its interests with 
their own. It is seldom that officials give up their position, since they see their future assured in the service of the firm. The workmen also remain permanently attached to the firm, as the amount of the pension rises with the uninterrupted period of service. After thirty years continuous service the full old age pension commences with two thirds of the wages; and that this is of practical importance is proved by the respectable number of old age pensioners who are still strong and hearty, and beside their pension continue to receive their full wages. But almost more than the prospect of a pension the endowment fund for widows and orphans connected with the pension fund binds the workmen to the firm. It has been proved to be the case that this endowment is still more urgent than the invalid pension, as the uncertainty of the future of those dependent on him commonly weighs more heavily on the workman than his own. The ageing workman nearly always loves his work, and does not willingly lay it down without actual and serious need of rest. Accordingly the superannuation fund of the firm, in spite of a liberal use of the pensions by the workmen themselves, has only consumed the smaller part of the incomings from the interest of the funded capital and the contributions of the firm towards pensions; the larger part could be applied for the support of widows and orphans as well as for increasing the capital stock of the fund, which is destined to secure the workman's claim for pensions in the event of the possible liquidation of the business. 
The reproach has been made to this arrangement that it binds the workman too much to the particular workshop, because by his leaving it he loses the advantages gained. This is quite true, although the hardship is considerably mitigated by the circumstance that with dismissal for want of work every dismissed workman receives a paper, giving him a preferential claim to re-admission over other workmen. Certainly the workman's freedom to strike is considerably restricted by the conditions regarding pensions, for on his voluntarily leaving his old age claims lapse by the rules. It is however to the interest of both parties that a permanent working staff should be formed, for only thereby is the firm enabled to maintain the workmen even in unfavourable times and to pay them wages affording subsistence. Every large factory ought to form such a pension-fund, to which the workmen contribute nothing, but which they themselves manage, of course under the control of the firm. In this manner the strike mania, which seriously injures industry and especially the workmen themselves, is best coped with.

It is certainly somewhat hard that the provisions of the Workmen's Old Age Insurance. Law of Germany have no regard to the already existing or prospective private pension funds, and thus oblige the particular factories to pay double for pensioning their workmen. However the peaceful relations between employers and employees, which are secured by the private pension fund, as well as a permanent staff of 
workmen, are so important, that such an excess of expenditure is amply justified.

The esprit de corps produced by the arrangements described, which binds together all the fellow labourers of the firm of Siemens \& Halske, and gives them an interest in its welfare, explains in great part the commercial success which we achieved.

This leads me to the question, whether altogether it is to the general interest that large commercial houses should be established, which permanently remain in the possession of the family of the founder. It might be said that such large firms are hindrances to the rise of many smaller undertakings and therefore act injuriously. That is certainly pertinent in many cases. Wherever it is possible to maintain an export trade by the productions of handicraftsmen, large competing factories have a prejudicial effect. Wherever, on the contrary, the development of new branches of industry or the opening of the markets of the world for those already in existence comes into question, large centralised business undertakings with abundant - capital are indispensable. Such capitals can certainly at the present day be most easily brought together in the form of joint stock companies, but these can nearly always be only pure gain-seeking companies which, by their own regulations, are only allowed to have in view the attainment of the largest possible amount of profit. They are therefore only adapted for reaping advantage from already existing welltried methods of working and organizations. The 
opening of new paths is on the contrary nearly always troublesome and attended with great risk, requires also a larger store of special knowledge and experience than is to be found in joint stock companies, for the most part short-lived and often changing their management. Such an aggregation of capital, knowledge, and experience can only be formed and maintained in long established commercial houses, remaining by inheritance in the same family. Just as the great commercial houses of the Middle Ages were not only money-making institutions, but considered themselves called upon and bound to serve their fellow-citizens and the state by seeking out new commodities and new highways of commerce - the obligation being transmitted as a family tradition through many generations - so at the present day in this awakened scientific age the large technical businesshouses are called upon to put forth their whole strength, that the national industry may take the lead in the great contest of the civilized world, or at least the place assigned to it by the nature and situation of the country itself. Our political institutions still rest almost everywhere on the feudal system, according to which the landed proprietor was almost exclusively regarded and honoured as the supporter and maintainer of the power of the State. Our time can no longer recognize the validity of this privilege. Not on possessions, be they what they may, will the conservative force of society henceforth depend, but on the spirit which animates and fertilizes them. Al- 
though it is conceded that inherited possession of the soil binds by tradition and education the owner more firmly to the state, and is therefore more conservative than land easily transferable and capital altogether moveable, it yet no longer suffices to protect the state from impoverishment and decay. This protection can only be secured to-day by the conscious co-operation of all the spiritual forces of the nation, the maintenance and further development of which is one of the most important problems of the modern state.

Although the fact, that I owe my position in life to my own efforts, has always afforded me a certain satisfaction, yet I have always gratefully acknowledged that my path was smoothed by my admission into the Prussian army and therewith into the State of the great Frederick. I regard the cabinet order of Frederick William III., which accorded me the entry into the Prussian army, as the opening of the only path then possible, in which my energies could be developed. I have often, in my later life, had opportunity to perceive how true had been the utterance of my father that, in spite of all discontent with the Prussian policy of the Holy Alliance, Prussia was yet the only firm point in Germany and the only anchorage for the hearts of German patriots. I have therefore always bestowed my, I may well say, inborn affection to the German fatherland first and foremost on Prussia, and have always been faithfully and grate- 
fully devoted to it and its five kings, under whose rule I lived. It was not only the knowledge to be acquired at the Prussian military schools and the mental culture there attained, which facilitated my later progress in life, it was also the position of military officer held in such esteem in Prussia, which was of the greatest assistance to me.

Prussia was, as I have already mentioned in another place, down to the middle of the present century essentially a military and bureaucratic state, only to the nobility and landed gentry certain honorary privileges appertained. An industrial class proper was entirely wanting, in spite of all the effort which enlightened officials, such as Beuth, made in order to form one from the insufficiently developed artisan class. Moreover, as the trade of the country was very limited, there was also wanting a prosperous cultured middle class as counterpoise to the army, the officials, and the landed nobility. Under these circumstances it was in Prussia of great value, to belong as officer to the court-retinue and to have the entrée to all social circles.

It is customary at the Prussian court for this privilege, possessed by every, even the civil officer, of belonging to the court-circle to be continually exercised. Thus as early as the winter of 1838 , when a young officer in the artillery and engineering school, I was commanded to attend great entertainments at the royal palace, and since that time, accordingly for more than half a century, I have frequently been per- 
mitted to be present at these great court gatherings, which faithfully reflect Berlin society and clearly illustrate the immense revolution which Prussia, and all Germany with it, has undergone during that time. At these assemblies I have frequently had the opportunity of becoming personally acquainted with the members of the Royal Family.

As previously mentioned, I had already had occasion at an earlier period of my life to be grateful to the Prince of Prussia for his kindness in liberating me at St. Petersburg from a painful position. I have ever retained this feeling of gratitude, but unfortunately in consequence of my political views was constrained to incur the anger of the monarch by voting in the Diet according to my convictions against the reorganization of the army. When the declaration of war against Austria had actually taken place, and the brilliant victories of the reorganized Prussian army had clearly proved the wisdom of the strengthening of the army by this reorganization, I took indeed pains to help to remove the injurious consequences of the parliamentary resistance to the reorganization, and successfully struggled for the grant of the indemnity so magnanimously asked for by the victorious ruler, but hardly thought I could ever hope to regain the former favour of the sovereign. I was therefore all the more agreeably surprised when at the close of the Paris Universal Exhibition of 1867, at the same time

- as the French croix d'honneur, the Prussian Order of the Crown was conferred upon me. 
A few years later the Emperor gave a still more decided expression to this renewal of favour with a kindliness, which could hardly be surpassed. I had already for a number of years been a member of the Council of the Berlin Merchants' Company, and according to the prevailing practice had been proposed by the president of the Company for nomination as Councillor of Commerce, without my knowing anything about it. The Emperor had already approved of the nomination, and the president of police was kind enough to call upon 'me and personally to bring me the gratifying intelligence of this impressive mark of favour. The title of Councillor of Commerce however was not. quite to my taste, for I considered and felt myself more a savant and engineer than a merchant. The president of police, who soon perceived my uneasiness, tried to combat my objection and asked, what he should say to the Emperor, who had desired to do me a favour. Whereupon the remark slipped off my tongue, that first lieutenant, honorary doctor of philosophy, and Commercial Councillor did not agree, such a mixture would produce a stomach-ache! The police-president finally promised to convey my petition to the Emperor that my appointment as Councillor of Commerce should not be published, and we agreed to meet at a particular spot at the court ball to be given the same evening. He there came up to me with a cheerful countenance, and reported that he had communicated to the Emperor my scruples regarding the stomach-ache; that the Emperor had laughed heartily at it, and remarked he 
himself felt something of the same sort, I should therefore ask for some other favour when he addressed me. This unfortunately I could not do. A title more in accordance with my position did not exist in Prussia for non-officials and I could not possibly follow the advice of the president to request a higher order, since, as I said to him, one gratefully accepts such when offered, but does not solicit it. This refusal gave offence to the president, and as the Emperor soon after passed without addressing-me, I imagined I had again incurred his displeasure. All the more delighted, nay almost abashed was I, when the president of pölice communicated to me, he had told the Emperor that I knew of nothing to ask from him, and that he had thereupon replied "well then, present him to my wife".

In consequence of a mistake in persons this presentation did not take place then, and I also afterwards omitted to be presented to the Empress in the usual way, as it was repugnant to me to force myself into the presence of royalty, as is so often done. That this did not pass unnoticed I afterwards learnt from the Empress herself. During the Vienna Exhibition of 1873 the latter requested the German jurors to be presented to her, I being one of them. After the presentation was over, she sent for me specially and said: "I have a bone to pick with you, Herr Siemens, you try to give us the slip, but in future you will not find that so easy". Indeed the august lady often afterwards gave me proofs of her 
esteem and graciousness in visiting our factories or inviting me to give lectures on electrical subjects.

One of these lectures, which I had to give in the Imperial palace, had special significance through the Grand Duke of Baden on the day before the delivery of the lecture having sent me a programme, precise both in extent and subject, which the Emperor himself had dictated to him. The theme ran "Nature and cause of electricity and its application in practical life". It was not easy to satisfy the theoretical part of the programme, as our knowledge of the nature of electricity is still very slight, but even the drawing up of such a programme shows how profound was the interest taken by the Emperor in the physical sciences, the great importance of which for the further development of human civilization he fully perceived. The Crown Prince and his family have also invariably displayed the liveliest interest in the gradual development and the scientific achievements of our establishment, and have frequently honoured our factories with their presence. To this gracious and kindly recognition of my efforts $I$, in fact, owe my place in the list of recipients of honours, which the Emperor Frederick announced on ascending the throne. Without the usual preliminary inquiry I was included in the list, and to my great astonishment first heard through the newspapers of my admission into the ranks of the nobility. 
Although my time was very much taken up with my scientific work and my business, I yet never lost my interest in the questions of public life. I was an active member of several scientific and technical societies, took part both commercially and privately in the great exhibitions, and was frequently appointed by the government on special commissions for scientific and technical questions. Of this multifarious activity I shall here only cite a few instances, which appear to me worthy of mention.

When the Imperial patent law came into being, substantially in accordance with my proposals, an invitation was issued to me to assist the newly constituted Patent Office at least for a number of years. I willingly complied, in order to be enabled to secure that the practical application should be in harmony with the adopted principles of the patent law. In this manner I obtained the rank of an official of the Empire and as such was proposed by Prince Bismarck - for the title of "Privy Councillor". I gratefully accepted the same, as the bearing of a title in Prussia is very general and my colleagues, the members of the Academy of Sciences, for the most part bore it.

I was an active member and for a number of years deputy-chairman of the Association for the Promotion of Industry, which was called into existence by Beuth, the father of Prussian industry, and rendered great service to the industrial development of Germany under the many years' presidency of the State Minister Delbrück. 
I had a large share in the establishment of the Electro-Technical Society through the mediation of the Secretary of State Dr. von Stephan. I was the first active president of the Society and made many of my technical labours for the first time public through lectures in this Society. Similar societies were founded in several places after the pattern of the Berlin ElectroTechnical Society; at the same time the meritorious older Society of Telegraph Engineers in London, called into existence by my brother William, expanded their name and programme by adopting electric engineering as the aim of the Society. The formation of the Berlin Society is to be regarded as the commencement of electro-technical science as a special branch of civil engineering, the term "electro-technical" itself occurring for the first time in the designation of the Society. By the adoption of the resolution subsequently brought forward by me, "to request governments to establish professorships of electric engineering at all technical academies, in order that young engineers may have the opportunity of getting to know the assistance which electrical technology might afford them in their special work", the Society has rendered good service as regards the rapid development of electric engineering in all its branches, as the resolution was almost everywhere complied with. Also by its endeavours to obtain an international system of electric standards, the Society has done great service. The initiative was taken by the Congress, which was connected with the Industrial Electric Exhibition in Paris of 1881, - a 
request being preferred to the French government to bring about diplomatically the assembling of an international conference of delegates, whose task should be the establishment of a scientific system of standards for electro-technology.

Such a conference, to which Helmholtz, Wiedemann, Clausius, Kirchhoff and myself were deputed by the German Empire, met in Paris in the following year, and decided in principle for the absolute standard system of William Weber, with the modification that the c. g. s. standard, for which England had already pronounced, was adopted as the standard of resistance. Owing to the little accuracy however, with which hitherto the absolute resistance unit of Weber could be reproduced in practice, it was resolved to take as a practical basis the mercury unit, which I had proposed, and to invite the scientists of every country, to settle experimentally the relation of the modified c. g. s. unit to the then widely adopted Siemens unit. As the mean of all the determinations in consequence arrived at there resulted for this relation the value 1.06 ; and accordingly a column of mercury of 1 square millimetre in cross section and 106 centimetres long at $0^{\circ} \mathrm{C}$. named "Ohm" was established at the final conference in the year 1884 as the international legal unit of resistance. In like manner the names of meritorious physicists were selected for the remaining units of the system; it is however to be regretted that the name of William Weber, the creator of this absolute standard system, was passed over, 
although this honour ought to have been specially paid him, when his own system was adopted. For myself it was a little triumph that a reproduction of my mercury unit, which Lord Rayleigh made according to a method somewhat different from my own, should yet agree to a ten thousandth part with the standard tallies delivered by our firm.

It was certainly somewhat hard for me, that my resistance unit, arrived at with so much trouble and labour, which had speaking generally made the first comparable electric measurements possible, then was employed for more than a decennium throughout the world and adopted as legal international standard of resistance for telegraphy by the International Telegraph Congress, should have now suddenly to be set aside with my own co-operation. But the great advantage of a theoretically established system of standards, consistently carried out and universally adopted, necessitated this sacrifice offered up to science and the public interest.

My literary activity was in general limited to the presentation of my scientific and technical labours and the description of the mechanical contrivances which I had constructed. I was however often obliged to repel attacks, which were levelled directly or indirectly at my firm or at myself personally. This was the more necessary as my firm never advertised, 
and only let good workmanship proclaim its merits. Unfounded attacks on its achievements could therefore not pass unchallenged, which frequently had to take the form of an appeal to the law of libel, as the newspapers usually had more sympathy for their regular profitable advertisers.

Of such rectifications I will only here instance one sent in April 1877 to the Elberfelder Zeitung, since it is of a more general interest. The anonymous writer, who gave occasion to this rectification, had praised the dynamo-electric machines of M. Gramme in Paris, whom he styled the meritorious inventor of the dynamo-electric machine and electric lighting, and for whose recognition he claimed the German love of justice in high-sounding phrases, without even making mention at all of the German share in these inventions. In my reply I emphasized the undoubted merit of Gramme in the development of the dynamo-electric machine, which consisted in the combination of the ring of Pacinotti with my dynamo-electric principle, I could however not omit to reverse the appeal to German love of justice in favour of foreign services by pointing to the fact that the Grerman is always inclined rather to recognise foreign and exotic than home growths. This was, I added, a great obstacle to the development of German industry, since the làtter was often compelled by the preference for foreign manufactures to send its better products to the markets of the world under a foreign flag, whence it came to pass 
that German manufactures were everywhere wrongfully characterized as inferior cheap wares.

I have had occasion before to refer to this, and in particular have characterized as unpatriotic and despicable the suicidal practice of bringing the better German manufactures to market as English, French, or even American. It is difficult to decide whether the blame rests mainly with the German public or the German manufacturers, in any case it is the outcome of a reciprocal action between the prejudice of the former and the short-sightedness of the latter, who have only their momentary advantage in view. Since the establishment of the new German Empire and the national advance connected with it there has undoubtedly been an improvement in this respect, but the eradication of the evil is still far from complete. Our manufacturers still too much lack the pride to supply only good articles, and our public the perception that such commodities even at a higher price are the cheapest. Only from the reciprocal action of both is the national pride in the products of one's own industry developed, which affords the best protection for the latter. How strongly the feeling of the superiority of native to all foreign products is developed in England was vividly brought home to me, when I was once watching, with brother William, the unloading of a vessel, which for the first time brought ice to London from a Norwegian port. The ice was deposited in handsome cubical blocks on the landing place, and was regarded with manifest 
interest by the purchasers. My brother began a conversation with one of them by praising the fine appearance of the blocks. "Oh yes" was the reply of the person addressed, a herculean butcher, "it looks very well but it has not the English nature". Even English ice must necessarily be colder than foreign ice. This prepossession of every Englishman in favour of native products, which always influences his choice, strengthens the pride of the English artisan and manufacturer in the excellence of their work and thereby often causes the preconceived opinion to become truth.

Of my other popular publications I will here only cite my lectures "Electricity in the service of life" of the year 1879 and "The Age of Science" of the year 1886 .

In the former lecture I descanted on the state of electrical engineering and added some reflections on the further progress, confidently to be expected, which would result from the circumstance that electricity could now with the help of the dynamo-electric machine also perform heavy work, whereas hitherto it had only been useful through the rapidity of its action in mediating, directing, and controlling intelligence and signals, leaving the execution of the heavy work itself to other natural forces.

The lecture "On the Age of Science", which I gave at Berlin at the opening meeting of the Society of Naturalists and Physicians in the autumn of 1886 , dealt with the change of social conditions through the 
rapidly growing command of man over the forces of Nature. I set forth that engineering, resting on the basis of physical science, was more and more relieving man of the previous severe bodily labour, which Nature had imposed on him for the maintenance of his life, that the wants of life and means of enjoyment would be satisfied by ever diminishing bodily exertion, and thus become cheaper and accordingly more accessible to all; further that through the distribution of force and the inevitable fall of the rate of interest the superiority of large factories to individual labour would more and more be neutralized and consequently the practical ends of Social Democracy would be attained without a violent overthrow of the existing order solely by the undisturbed progress of the Age of Science. I also tried in my lecture to show that the study of the physical sciences in its further progress and general diffusion would not brutalize men and divert them from ideal aspirations, but on the contrary would lead them to humble admiration of the incomprehensible wisdom pervading the whole creation, and must therefore ennoble and improve them. The occasion appeared to me opportune for publicly asserting my convictions, since the unshakable belief in the beneficial consequences of the undisturbed development of the Age of Science is alone competent to repel with success all the fanatical attacks which threaten human civilization on all sides.

It is not sufficient however to leave scientific engineering to its own undisturbed development, it is 
rather necessary to assist its progress as far as possible. For this certainly already much has been done in Germany through the highly developed system of scientific technical instruction, for which the best conceivable arrangements have been made at the numerous universities and polytechnic schools. There was a total absence however of any organization for the furtherance of scientific investigation, i. e. for the extension of the area of our physical knowledge, on which technical progress is also dependent. In Prussia years ago the necessity of an institute had been perceived, which should have for its object the scientific support of engineering and especially of applied mechanics, and a commission, to which I was summoned, had elaborated a plan for such an institute, which was to be added to the new polytechnic institution in course of erection at Charlottenburg. This was however no solution of the problem of furthering scientific investigation itself.

The necessity of an institute, not subserving instruction but scientific research exclusively, had very strikingly appeared at the conferences on the establishment of international electric standards in Paris. There was found no suitable place in all Germany for carrying out the difficult work of exactly producing the absolute resistance unit of Weber. The laboratories of the universities are, in conformity with their destination, arranged for the purpose of instruction and indeed as a rule entirely claimed for that object. German scientists have nevertheless in the leisure-hours, 
which their teaching vocation left them, used these for carrying on their researches, and have accomplished much, but for extensive thorough research neither the rooms and their fittings nor the leisure-time of the scientists were sufficient. My proposal to add to the planned institute for the scientific support of engineering a second, which should be exclusively at the service of scientific research, met indeed with much sympathy, but the execution of the plan was regarded as impossible under the existing circumstances. Suitable premises were wanting, sufficiently large and not liable to vibration from vehicular traffic, and it also appeared difficult to obtain the consent of the Prussian Diet to the considerable expenditure required for the erection and subsequent maintenance of such an institution.

I had already bequeathed in my will a considerable sum of money to be applied to the furtherance of scientific research, but precious time would perhaps have been lost before my possibly still remote death, and particularly the favourable opportunity would then have gone by for calling into life a large undertaking, answering to the needs of the time, by the combination of the planned institute destined for scientific research with the scientific-technical one already agreed to in principle. I therefore resolved not to wait till my death, but to make the Imperial Government the offer, to place at its disposal a large piece of ground perfectly suited to the purpose or the equivalent capital for an Imperial institute devoted to scientific 
376 ERection of a physico-techNical imperial institute.

research, if the Empire would undertake the cost of building and the future maintenance of the institute. My proposal was accepted by the Government, confirmed by Parliament, and on this foundation the physico-technical Imperial institute at Charlottenburg has grown up, which now forms a German home for scientific research under the guidance of the first physicist of our time, Privy Councillor von Helmholtz. 
Charlottenburg, June 1892.

I hoped last year to bring these recollections to a close in Harzburg, but was prevented by my wife's illness and many other troubles. In the autumn I had myself a severe attack of influenza, which compelled me to winter in the south. Accompanied by my wife and youngest daughter I resorted to Corfu in December. It is true that there is not much provision in the place for sick persons, and the climate in January and February is about the same as that of a rainy North German summer, but the glorious situation and the beautiful surroundings of the town afford great pleasure even at that season of the year.

Corfu still lives on the benefits, which the English protectorate formerly brought the island. The fine roads made by the English, although already in part thoroughly out of repair, still continue to afford fair communication between the most important parts of the island. The English waterworks also, which have made the city of Corfu a healthy place, are luckily still kept up. Till a short time ago the Corfiote lived in ancient Phaeacian ease on the profits, which the 
numerous old olive-trees of the island brought him; he never took the trouble properly to gather the fruit, but waited till it fell to the ground of itself, and then collected what was in good condition. Recently however petroleum has sent down the price of oil, and anxiety for daily bread is beginning to be felt even in Phaeacia. Greater attention is therefore now paid to the cultivation of the vine, which indeed costs much more labour, but is also far more remunerative than the cultivation of the olive. One sees with regret in many parts of the island the old picturesque olive-trees cut down to make room for the more profitable vine-cultivation. Almost the only foreigners, who permanently reside in Corfu, are French traders, who buy up all the wine. The large amount of red colouring matter, which the wine of Corfu contains, doubtless makes it very suitable for the manufacture of "genuine" claret. In former times no wine could be exported from the island, as the Corfiotes preferred to drink their wine themselves. Thus the most ancient habits change in an age that does not suffer the unchangeable!

At the end of February, when the fruit-trees began to bloom, we left Corfu and went to Naples, where we hoped to find better weather and more amusement. But the Apennines were still thickly covered with snow, even dear Vesuvius wore a light snowy mantle, and in Naples it rained still more persistently and severely than in Corfu. As a compensation we there enjoyed the pleasant intercourse with friend 
Dohrn and his amiable family. A month later we went to Amalfi, but not before Sorrento did the long ardently desired blue Italian sky at last smile upon us. There I first began to feel my strength returning when, taking a walk with my wife, we were attracted by the prospect of a fine view and reached the highest point of the neighbourhood, the monastery of Deserto. My hope of being able to pay another visit to Vesuvius, and perhaps of taking another look into the sources of its changing activity, unfortunately remained unfulfilled, on account of the unfavourable weather. It gave me however much pleasure to see it again, for one clings to persons and things, which have earned our gratitude. For during an ascent in the year 1878 Vesuvius had given me such unmistakable indications of the cause of its activity by its regularly recurring explosion-like eruptions, that the sphere of my ideas concerning the formation of the earth's crust and the underlying forces was considerably enlarged.

At the beginning of May we returned home, but unfortunately I had yet to sustain two violent attacks of fever. Having now luckily got the better of these likewise, I hope that the sick period of my old age is passed and that a calm and cheery evening of life will be granted me in the midst of my beloved ones.

I have already in the foregoing pages frequently spoken of my brothers and sisters, but considering the great influence, which they had on my career, I feel 
constrained to append a condensed and connected summary of their lives.

I will first mention my brother William, snatched, alas! so early from us. How in a foreign land, which he set foot upon without any acquaintances and introductions and with very limited means, he worked himself up to a position of great distinction, has been admirably recorded by the pen of so competent a writer as Dr. Pole. Many foreigners, Germans among the rest, have made their fortunes in England, but that has usually depended on certain lucky hits, among which a single invention of great material importance is commonly to be reckoned. William achieved more, he forced the public opinion of England to honour him in his life-time, and in a still more striking manner after his death, as one of the leading spirits, to whom the country owes the great development of its technical industry by the diffusion and application of scientific knowledge. By participating indefatigably in the work of the numerous associations, which made good in England the previous want of sound preliminary technical education, William contributed much to bringing English engineering up to the level of advanced physical science, and it redounds to England's honour to have impartially acknowledged this service on the part of a foreigner. William's exertions were considerably assisted by the uninterrupted and close connection with his brothers, and by his marriage with the amiable Miss Gordon of an honourable Scottish family, which made it easier for him to obtain a firm footing in English society. 
William died on the $19^{\text {th }}$ of November 1883 , in his sixtieth year, of a slowly developed and scarcely noticed disease of the heart. His almost sudden death overtook him at the height of his activity. Already all the honours had been heaped upon William, which a savant and engineer can obtain in England. He was repeatedly president of the foremost scientific and technical societies, amongst others first president of the Society of Telegraph Engineers and Electricians founded by himself. The highest recognitions and prizes accorded by these societies were awarded him. The Universities of Oxford and Cambridge made him honorary doctor; and he received the honour of knighthood at the hands of the Queen. His death was felt throughout England as a national calamity, and was as such lamented in all the newspapers. The funeral service took place with befitting solemnity in Westminster Abbey. A year after his death a window was dedicated to his memory in the Abbey, presented by the scientific and technical associations of England, the leading English men of science and representatives of technical industry taking part in the proceedings. His deeply afflicted wife retired to her beautiful country house, which the forethought of her husband had bequeathed her, at Sherwood, near Tunbridge Wells, there to mourn her lost happiness. We brothers, and $I$ in particular - for William was to me more than a brother - felt his unexpected death as a severe blow, which the lapse of now nearly ten years can soften but not expel from memory. 
Of my brothers Hans and Ferdinand, who became agriculturists, Hans afterwards devoted himself to agricultural engineering, and undertook a spirit distillery in Mecklenburg. That certainly did not bring much grist to his mill, but gave him the opportunity of falling in love and getting engaged. After his marriage he acquired with my assistance a bottle manufactury near Dresden, which he managed till his death in the year 1867. Ferdinand still lives on his manor of Piontken in East Prussia. He was again betrothed in 1856 and then married; one of his two daughters is the wife of my son William, and some years ago presented me with the first grandson.

My brother Frederick had in the fifties actively participated in William's efforts to improve his regenerative steam-engine and evaporating apparatus. In the year 1856 he hit on the happy idea of employing the regenerative system, hitherto but little successful, for metallurgical purposes, and in particular for reverberatory furnaces. A number of patents, which he took out in different countries, partly alone, partly in conjunction with William, for a perfected form of regenerative gas-furnaces, formed the basis of a furnacebuilding business established by William and himself. To work this in Germany and Austria, he transferred his residence to Berlin, shortly after his marriage in 1864. In 1867, after the death of our brother Hans, he took over the glass-works near Dresden, and by his technical gifts and energy soon raised the same into a model factory for glass manufacture. Through the 
introduction of the regenerative system, and afterwards of the heating by radiation, he gave the impulse to an epoch-making improvement in metallurgy and especially of the glass industry. Recently he has made over the Dresden glass-works and the works appertaining thereto in Bohemia to a joint-stock company, since they no longer afforded him material enough for his inventive activity. $\mathrm{He}$ is now busily engaged in perfecting his regenerative heating process and steel manufacture. In a widely different department also, that of gas-lighting, he has introduced great improvements, bringing into use in gas-burners the regenerative principle of heating, and in this manner has considerably increased the illuminating power of the gas. He has thereby not a little retarded the victory of the electric light over gas, which however has not produced a jar in our fraternal harmony. After William's death he undertook the latter's furnace business in England, and has continued it with the best success. An amiable wife and a charming troop of children will, we may hope, give him still many years of happiness and stimulate him for further untiring endeavours.

Charles had found in Russia a sphere of action extremely congenial to his faculties, and very considerably contributed, by the successful execution of our large undertakings, to the firm establishment and financially sound development of our business. But when in the year 1867 our Russian maintenance contracts expired, and the Russian government took all further telegraphic affairs into its own hands, the 
St. Petersburg firm seemed condemned to lose its position of importance. As about the same time Charles's wife began to ail, and a change of climate appeared urgently necessary for her, Charles transferred his abode to Tiflis, and undertook the management of the branch founded there, as well as of our Kedabeg mine, which had already grown to considerable proportions. Unhappily however the condition of his wife grew continually worse, a prolonged residence in Vienna and Berlin equally failing to restore her health. She died in Berlin in the year 1869, leaving Charles with one son and two daughters. I now proposed to Charles to stay in Berlin for good, and to take part in the management of the Berlin firm. We were even planning, as we were both widowers, building a house for joint occupation, when William came forward with the wish that Charles should settle in London. Charles accepted this proposal and till the year 1880 managed the business of Siemens Brothers \& Co. in conjunction with William. He showed himself in London, just as in St. Petersburg, a far-seeing man of business, an able organizer and manager of large undertakings. The factory at Charlton near Woolwich was considerably extended at his suggestion, the cable works especially much enlarged, and a gutta-percha factory set up. But after several years residence in England Charles's health, formerly always very good, began to show signs of decline; he could not bear for long the damp English climate. Moreover an irresistible longing manifested itself in his children for their native country 
Russia. For these reasons in 1880 Charles returned with them to St. Petersburg and once more undertook the management of the business there, which he soon raised again into a flourishing condition. His two daughters have married in Russia; his son assists him in the management of the business, so far as a disease of the eyes, with which he is unfortunately afflicted, allows. Charles's own health has been quite restored since quitting England. He himself, as well as the firm under his management, which is now chiefly occupied with arrangements for electric lighting and transmission of force, hold a highly esteemed position in Russia.

The youngest brothers Walter and Otto both died in Tiflis, and rest in the same grave. Walter died, as I have already stated, in consequence of a fall from his horse. He was a fine stately man, with pleasing ways, which quickly made him popular in the Caucasus; to us brothers he always showed the greatest attachment. Otto succumbed some years later to his feeble health, of which he had not always been sufficiently mindful. He was a highly gifted man of sterling worth, but did not always possess the requisite selfcontrol and strength of character, and has therefore often been a cause of anxiety to us older brothers. When he had contracted a serious lung disease in London, where he was to be prepared under William's guidance for a technical career, we sent him for a voyage round the world in a sailing ship, in the hope that this would effect a cure. He arrived in apparently 
good health in Australia, could not however resist the temptation to join an expedition, which was about to cross the continent, to seek for traces of the lost traveller Leichhardt. But the fatigue was too much for him, and he nearly perished in the desert interior from the effects of a haemorrhage. When after a series of further adventures he returned to England, we sent him to the Caucasus, which had often proved beneficial to consumptives. In truth a rather long stay in Kedabeg seemed to have perfectly restored him. At Walter's sudden death he entered upon the latter's functions. In the house of Prince Mirsky, governor of the Caucasus, he made the acquaintance and became enamoured of the widow of General Prince Mirsky - a brother of the governor - who had fallen in the Crimean war. Unhappily his death after a few years severed the union of the happy pair.

Our sister Matilda, the wife of Professor Himly, died at Kiel in the summer of 1878, mourned by us as an affectionate and faithful sister. Sister Sophia unhappily lost many years ago her husband, who at the time filled the office of advocate to the Supreme Court at Leipzig.

With regard to my own life in the last few years it only remains for me to mention that since the beginning of $1890 \mathrm{I}$ have left the business management of the firm of Siemens \& Halske at Berlin, Charlottenburg, St. Petersburg, and Vienna to the former active partners, my brother Charles and my sons Arnold and William, and am now only a sleeping partner in the 
firm. It is a great joy to me to be able to testify that my sons have shown themselves fully equal to their grave and responsible position, nay that my retirement has manifestly given to the firm a fresh impulse. This is the more deserving of recognition as my old assistants in the technical management, Messrs. Frischen, von Hefner, and Lent, are also no • longer in the firm, the first named being unhappily taken from his labours by death. It is with commercial houses as with states, they need from time to time regeneration in their administration, in order themselves to remain young. The London business and my private undertakings were not affected by my retirement from the firm of Siemens \& Halske, and thus continue to give me sufficient technical occupation.

My children by the first union are all happily married. My first-born, Arnold, married the daughter of my friend von Helmholtz, and has already, as well as his brother, provided for a continuation of the lineage by two grandsons.

When at its close I survey my life, and search for the determining causes and impelling forces, which carried me over all hindrances and dangers to a position which brought me outward recognition and inward satisfaction, and superabundantly provided me with the material blessings of life, I am bound to admit that many fortunate circumstances have co-operated and that altogether I owe a large debt to fortune. 
It was a lucky coincidence that my early years were passed in a time of rapid progress of physical science, and that I devoted myself especially to electrical engineering, when it was still quite undeveloped and therefore formed a very fertile ground for inventions and improvements. On the other hand however I have also frequently had to contend with very unusual misfortune. This continual struggle with altogether unexpected difficulties and unlucky accidents, which in the commencement usually hampered my undertakings, but which I mostly by good hap succeeded in overcoming, William Meyer, the dear friend of my youth and faithful companion, very forcibly described in students' slang as: "Sau beim Pech" (bad luck coupled with astonishing flukes). $\angle \mathrm{I}$ must admit the correctness of this view, but still do not believe that it was only blind fate, when the wave of happiness and unhappiness, on which our life is tossed, carried me so frequently to the desired goals. Success and failure, victory and defeat, often depend in human life entirely on the timely and right use of the opportunities offered. The quality of quickly making up one's mind in critical moments, and of doing the right thing without long reflection, has remained tolerably faithful to me during my whole existence, in spite of the somewhat dreamy life in which I frequently, I might almost say usually, was plunged. In innumerable cases this quality has preserved me from harm and rightly guided me in difficult situations. Undoubtedly a certain stimulus was always necessary to give me full control of my 
mental qualities. I needed it, not only to be snatched from my own meditative life, but also as a protection against my own weaknesses. Among these I especially reckon an excessive benignity, which made it uncommonly hard for me to refuse a request, not to fulfil a known wish, nay in general to say or do anything to anybody that would be unpleasant or painful to him. Luckily this quality, very inconvenient especially for a business-man and master over many people, was neutralized by another, that of being easily provoked and excited to anger. This anger, which was always easily aroused, when my good intentions were misunderstood or abused, was ever a relief and outlet for my feelings, and I have often declared that anybody, with whom I had unpleasant dealings, could never do me a greater service than by giving me cause to be angry. For the rest this irascibility was usually only a form of mental excitement, which never got beyond my control. Although in younger years I was often nicknamed by my friends "curly head", wherewith they would hint at a certain connection between my curly hair and "curly" mind, yet my easily roused anger has never led me to actions which I had afterwards to regret. For a manager of great undertakings I was also in other respects but indifferently suited. I lacked the good memory, the orderly sense, and consistent, unbending strictness. If notwithstanding I have founded large business concerns and managed them with unusual success, this is a proof, that industry coupled with energy often over- 
comes our weaknesses or renders them less harmful. At the same time I can say on my own behalf that it was not desire of gain, which impelled me to devote my working power and my mind in so great a degree to technical undertakings. In the first place it was usually the interest for technical science which led me to my task. A business friend quizzed me once with the assertion, I let myself always be guided in my undertakings by the public benefit they would bring, but that ultimately I always found my account thereby. I admit this remark to be correct within certain limits, for such undertakings as further the general weal command a wide interest, and thereby present greater prospects of being successfully carried through. However I will not undervalue the powerful influence, which success and the consciousness arising from it of doing something useful, and at the same time of giving their bread to thousands of industrious workers, exerts on man. This gratifying consciousness has a stimulating effect on our mental qualities and is doubtless the foundation of the otherwise somewhat paradoxical German proverb: "To whom God gives an office, $\mathrm{He}$ also gives understanding".

A main reason of the rapid growth of our factories is, in my opinion, that the products of our manufacture were in large part results of our own inventions. Though these were in most cases not protected by patents, they yet always gave us the start of our competitors, which usually lasted until we gained a fresh start by new improvements. This could 
certainly only have lasting effect in consequence of the reputation for great solidity and excellence, which our productions enjoyed throughout the world.

Besides this public recognition of my technical achievements marks of honour have been so abundantly conferred upon me personally both by the rulers of the larger states of Europe and by universities, academies, scientific and technical institutes and societies, that hardly anything remains for me to desire.

I began the writing of my recollections with the biblical aphorism "The days of our years are threescore years and ten, or even by reason of strength fourscore years", and I think I have shown that also the close of the sentence, "yet is their pride but labour and sorrow", has held good in my case. For my life was beautiful, because it essentially consisted of successful labour and useful work, and if I finally give expression to the regret that it is approaching its end, I am only urged thereto by the pain that I must be parted from my dear ones, and that it is not permitted me to continue to labour for the full development of the Age of Science. 


\section{APPENDIX.}





\section{I have in the foregoing reminiscences frequently}

had occasion to make some explanatory observations on my technical papers, which are described in the second volume of the collection of my "Scientific and technical papers" published in the years 1889 and 1891 by Julius Springer**). I have called attention to most of my earliest scientific writings, as they have had great influence on my career, and as they have probably remained unknown to the younger generation of physicists. I feel however the need of making also some critical remarks, accompanied by an estimate of results, on my later scientific work, which in many points diverges from the accustomed paths of the prevalent physical theories and has therefore found no general recognition.

In several papers written in the years 1860 to 1866, and published in Poggendorff's Amnalen, I investigated the question of the electric conductivity of metals, and proposed the first and up till now only method of obtaining an empirical reproducible standard of resistance. I showed that my method made it possible to determine exactly the resistance of an

*) English edition published by John Murray. 
approximately prismatic space filled with pure mercury to within a ten thousandth of its value, and thus solved the question of an absolute unit of resistance, i. e. one resting on a definition, with an exactness corresponding to the fineness of our measuring instruments. By these means exact and comparable electric measurements were first rendered possible.

In the course of this investigation I confirmed the proposition, already laid down by others, that solid alloys always exhibit a greater resistance than corresponds to the resistances of the several component metals; I showed however that this does not hold good for Anid metallic combinations, which retain in the fluid state the resistance of the single metals unchanged. This behaviour of the metals I showed could be utililized for the determination of the specific resistance in the fluid state of metals not readily fusible. Further I discovered that the resistance of metals is considerably enhanced by fusion, and that at the same time the latent heat of fusion increases the resistance in a higher degree than the sensible heat of a solid or liquid conductor. I found too that the increase of resistance by fusion does not occur discontinuously, but that the resistance rises continuously within a certain range of temperature and joins without break the resistance curve of the fused metal. Hence I concluded that the physical processes of fusion and solidification essentially consist in the absorption and liberation of latent heat, which take place within a definite range of temperature during liquefaction. 
In a later essay on the dependence of the electric conductivity of carbon on temperature I have confirmed Matthiessen's assertion, that the conductivity of carbon increases with rising temperature, and have shown the objections of Beetz and Auerbach to be erroneous. In explanation of this surprising behaviour of carbon I advanced the hypothesis that the different states of carbon - charcoal, graphite, diamond - are allotropic states of "carbon devoid of latent heat" not occurring in Nature, and are essentially distinguished from one another by the quantity of absorbed latent heat.

This hypothesis was further confirmed and developed by an investigation of the property of selenium, discovered by Willoughby Smith, of being a better conductor of electricity in the light than in the dark. I found that besides the selenium, which is changed by a slight enhancement of temperature from the amorphous non-conducting into the crystalline conducting condition, there is still a third modification, which is produced by heating amorphous selenium a long time till near its melting point, i. e. to about $400^{\circ} \mathrm{F}$. Both these modifications of the electricityconducting selenium are essentially distinguished from one another by this, that the former conducts electrolytically, i. e. like the electrolytic fluid conductors, better at a higher temperature, the second, long and highly heated, on the other hand metallically, i. e. like the metals worse at a higher temperature. In this behaviour of amorphous selenium, rapidly cooled from the fused condition - viz. when heated to over 
$180^{\circ} \mathrm{F}$. of losing indeed a great part of its latent heat of fusion, retained in rapid solidification, and of becoming electrolytically conductive, but with longer continued and higher heating in the vicinity of its melting point, of giving off more latent heat, and then of becoming still better conductive and that metallically - I found a confirmation of my previously suggested hypothesis, that the electrical resistance of a body is an equivalent for the quantity of heat stored up in it in the sensible as well as in the latent state. Further it seemed to prove that latent heat has a greater power than sensible heat of causing resistance, and that bodies without allotropically latent heat conduct metallically, and moreover in such a way that the resistance increases uniformly with the temperature reckoning from zero, whilst the resistance-causing influence of allotropically latent heat decreases with rising temperature.

According to this theory all simple bodies, which are not an allotropic modification of their original metallic primitive state, in which heat has become latent, must conduct metallically, and it is probable that the so-called active state of bodies is nothing else than this state devoid of latent heat, termed by me the metallic, which in semi- and non-metals can only occur in chemical combinations without passing immediately into an allotropic modification, heat becoming latent. According to this hypothesis we have therefore to imagine, that the molecules of all non-metallic solid bodies can assume different positions of stability, corre- 
sponding to definite quantities of work, which have been used up for constituting them. Only metallically constituted bodies can enter into chemical combinations. Latent heat therefore forms an obstacle to chemical combination, and if such nevertheless occurs heat must at the same time become sensible. Conversely a body becoming chemically free must be constituted metallically, is therefore in the active state at the moment of becoming free. Left to itself heat becomes latent by absorption of sensible heat, if it is a semi- or non-metal, whereby its electric conductivity is then partially or wholly destroyed. Heightened temperature makes the molecular arrangement, which corresponds to the heat absorbed, less stable, enhances therefore the electrical conductivity and at the same time the chemical affinity. Since heat becomes latent when metals form alloys, the conductive resistance of such alloys does not increase in proportion to the absolute temperature, as with the simple pure metals, but the latent heat of combination of the alloy forms a disturbing element, which further increases the resistance and thereby nullifies the proportionality of the same to the absolute temperature.

I succeeded in employing also technically the metallically conductive modification II of crystalline selenium, discovered by me, for the construction of a selenium photometer.

In an older paper I furnished the proof, that the dielectric becomes heated by repeated charge and discharge, and thereby found an experimental confirmation of Faraday's molecular induction theory. 
In the year 1875 an opportunity occurred of bringing into use my modified method, proposed in 1845 , of measuring the velocity of propagation of electricity in suspended wires. The experiments; which were instituted with a double iron wire, $7 \cdot 87$ miles long, yielded a velocity of propagation of 150,300 miles, a result which satisfactorily agrees with Kirchhoff's calculated result, regard being had to retardation by the condenser action of the wires and to the selfinduction. Before the performance of these experiments, very carefully carried out by Dr. Frölich, I inclined to the opinion that the actual velocity of electricity in conductors would be immeasurably large, as an experiment, which I made with a caoutchouc tube more than a hundred feet long filled with water, did not show any perceptible difference in position of the spark marks. The velocity of propagation of electricity could accordingly not depend mainly on the specific resistance of the traversed conductor, and I regarded it therefore as probable that the very different values found by Wheatstone, Fizeau, Gounelle, and others, had only been expressions for the retardation by the charge of the conductors employed. This doubt was removed by the experiments described, for the further prosecution of which I have unfortunately never found time and opportunity.

I was led into a sphere of inquiry entirely new for me by an observation of the activity of Vesuvius in May 1878. It struck me that from the brightly glowing opening, at the apex of the lava cone, which 
had risen in the interior of the large dark crater, explosion-like eruptions occurred with great regularity at intervals of several seconds. More exact observation showed that each explosion was followed by an absorption of air, so powerful, that the opening often sucked in at the same time even ejected scoriae or stones, which were again precipitated in its vicinity. Inflammable gases, evolved continually from the earth's interior, must have become mixed in the upper vent of the crater with atmospheric air, which had been absorbed by the rarefaction of the air caused by the preceding explosion, and thereupon exploded, to produce anew a rarefied space. This observation led me to a consideration of the process of the formation of the earth and its present condition from a physicomechanical standpoint, the results of which differed considerably from the prevailing opinions.

Two diametrically opposed views have hitherto been advanced in geology, that of the pure geologists and that of the mathematicians. The former mostly adhere to the old view, already to be called historical, that the earth was once in a molten state, whilst air and water formed the likewise still glowing atmosphere, that then with progressive refrigeration and after formation of a solid crust the seas were disengaged, and with the help of frequent partial elevations and depressions of the crust deposited the vast sedimentary strata, which now cover almost the whole surface. These elevations and depressions were said to be produced by internal volcanic forces, which still to this day give evidence of 
themselves in volcanoes. English physicists, among them Sir William Thomson, now Lord Kelvin, have opposed this basis of the theory of the earth's formation with weighty arguments. Lord Kelvin has declared that the whole terrestrial body must be more solid than glass-hard steel, as calculation proves that its surface would otherwise participate in the tidal movement produced by the attraction of sun and moon, consequently an independent ocean-tide could not then occur. J. Thomson has supported this calculation by a physical consideration, which goes to show that the fusing temperature of bodies, which expand on solidification, is lowered by pressure, but of bodies, which contract on solidification, is heightened by pressure. Now since the silicates, as he infers, contract on solidification about $20 \%$, the pressure increasing with the depth would not allow the rock masses to fuse in spite of the heightened temperature, but make them still more solid.

It is remarkable that these diametrically opposed views on the nature of the earth's crust should have been before the world for years without giving rise to violent controversies, although the question at issue affects the very basis of practical geology. The geologists, as already mentioned, for the most part maintain the theory of a crust floating on a fluid or gaseous nucleus, and the mathematicians cling to Lord Kelvin's theory of a solid nucleus, without troubling themselves much about the difficulties in the way of explaining the actual formation of the surface! 
I have tried to solve this contradiction by showing that considerations having reference to actual facts opposed the physical foundations of Thomson's calculation. The chief of these is that Bischof's statement, that silicates become about $20^{\circ}$ heavier in passing from the fluid to the solid state, is incorrect - as follows at once from the well-kown fact, that solid silicates always float on the fused ones, when they have nearly assumed the temperature of the latter. Further I called attention to the point, that Lord Kelvin's calculation takes no notice of the time required by the viscous terrestrial mass to assume the form, which is every moment prescribed to it by the deforming tendencies of the attraction of the sun and moon. As in these changes of form we have to do with dislocations of masses, which stretch continuously over the whole body of the earth from molecule to molecule, and therefore require a considerable time to take place, no universal tidal wave could be produced, advancing uniformly with the earth's rotation, and altogether such an one could only arise to a very slight degree. A refutation of these objections to the mathematical necessity of a. solid core is still wanting, and we are therefore entitled, in discussing the formation of the earth's surface to assume a viscous or gaseous state of the interior.

As regards the formation of the earth's surface the local elevations, the formation of the stratified diluvium covering almost the whole surface, earthquakes and volcanoes, have also a special interest for the non-geologist. I have tried to give an explana- 
tion of these facts resting on a physico-mechanical basis, which satisfies my own desire to get at the cause of things, but which frequently runs counter to the traditional geological views, and therefore has remained almost unnoticed. Of these traditional views I am compelled to declare untenable the one underlying all the rest, that there has been a period, when the earth was in a molten state and surrounded by an atmosphere, which contained the permanent gases and all the water in the form of glowing vapour. The reasons which influence me will become clear, if we go a step further back to the period, when the terrestrial mass assumed the globular form. Its elements must then have been uniformily commingled, and thus been condensed into a magma by mutual attraction in the gaseous state. A segregation of the more volatile bodies could only occur at the point of solidification, when the gaseous state passed into the fluid and solid. A separation of the more volatile bodies in the gaseous state could then take place according to the progress of this solidifying zone. This separation from the molten interior could however only proceed very slowly, as inferior specific gravity was the only existing force, which could drive to the periphery conglomerations of specifically lighter masses. How great such a difference of density is in the earth's interior cannot be determined, since our knowledge of the behaviour of bodies subjected to such high temperatures and pressures, as prevail in the interior of the earth, is still too slight. It appears however clear 
that the segregation of our atmosphere and our seas from the terrestrial mass was the work of many geological periods and is not yet completed, as the still active geysers and hot springs testify. We shall be compelled to assume a "Geyser period" as a special geological period, which followed the formation of the solid crust, and in which volcanoes and geysers ejected at innumerable places of the solidified surface the specifically lighter masses, especially water and air, and with the help of the varying currents of the sea formed by them deposited the stratified sediments. The assumption too of the upheaval of mountains by internal pressure does not agree with the assumption of a molten or gaseous interior, on which the solid crust floats. They can only be tangential forces, which have elevated mountains and are still elevating parts of the earth's surface. These tangential forces are supplied by progressive cooling of the interior, since the vault, formed by the solid covering of the earth, would collapse through gravitation, if the vanished fluid interior no longer sufficiently supported it. The phenomenon of volcanic eruptions does not necessitate the hypothesis of an internal pressure, which is stronger than corresponds to the weight of the solid crust. When we consider that the more recently cooled layers of solid rock must, with progressive refrigeration, be liable to rents, which we feel at the surface as earthquakes, it is clear that such rents may affect also the contiguous cooler crust, already frequently ruptured in former geological periods, and thereby bring about direct communications 
between the fluid interior and the surface. The still fluid terrestrial mass must then penetrate into these cracks, and as it is hot and therefore lighter than the superincumbent rock, it must burst forth and form a mountain, with a height corresponding to the difference of the specific gravity. As with the diminution of the pressure, exerted on the hot fluid ascending in the fissures, the gases and vapours contained in the magma must be set free, the bubbles of gas in the column of fluid rock will still further considerably diminish its specific gravity, and the height to which the fluid interior is raised in volcanoes is thereby explained, without the necessity of assuming a mysterious pressure in the interior overbalancing the hydraulic force.

It is surprising that professional geologists have left these views, modifying in such essential points the foundations of their traditional doctrines, unnoticed and unrefuted for now more than a decennium.

In an essay "On the luminosity of flame" I described a series of experiments on the problem of the radiation of light of gaseous bodies, which I partly instituted in the large glass furnaces, provided with regenerative heating, of my brother Frederick in Dresden and in conjunction with him. It appeared from these experiments that permanent gases, if entirely free of dust, are not luminous even at a very high temperature. As they at the same time possess a remarkable power of radiating heat, it is doubtless to be assumed, that with further increase of heat they must nevertheless at last begin to be luminous, because rays of light and 
heat are only distinguished from one another by the greater number of vibrations of the former, and because the radiating power in general seems to decrease with the number of vibrations. At any rate the power of radiating light appertaining to dust-free pure gases is so exceedingly small, that the luminosity of flame must be specifically different from the luminosity of the gases heated by the process of combustion. Apart from the luminosity of the solid particles separated by combustion or suspended as impurities in the gas, the luminosity of flame can only be an electrical process, which is connected with the chemically shifted position of the molecules of the burnt gases. The light of flame would according to that be just as much electric light as the light of the ozone tube or of the Geissler tube. The interesting controversy, in which my deceased brother William became involved with the astronomers through his work "On the conservation of the solar energy", led me also to the sun and occasioned my paper "On the admissibility of the assumption of an electrical solar potential and its importance for the explanation of terrestrial phenomena". As the known ways of producing electrical phenomena always depend on a separation of positive and negative electricity, we must assume that this holds good for the sun also, that therefore an electrical solar potential can only exist, if the one electricity is carried away from the sun. The theory set up by my brother, that solar matter is flung off and diffused in the universe in consequence of the sun's rotation, makes therefore the supposition of a 
solar potential admissible. The objection of the astronomers that interplanetary space cannot contain the smallest quantity of matter, because then the period of the planets would be increased, I sought to refute by the consideration that the matter itself, expelled from the sun, must rotate round the sun with planetary velocity, that it could not therefore impede the course of the planets. I also supported my brother's view that the solar light arises from the burning solar mass in its ascension, although I could only to a certain extent assent to his view that the combustible atmosphere resting on a fluid or solid solar surface, which is flung off in the burnt state and then again dissociated by the sunlight in space, and in this state again attracted by the sun, was the cause of the solar rays. I could only assent to it so far as the participation of the whole gaseous mass of the sun in the combustion was concerned, and could assign to the flung-off mass only a secondary importance in the thermal economy of the sun, but on the other hand considered it decisive as regards the question of its electrical charge.

Ritter's admirable and still insufficiently appreciated works remove all doubts as to the sun's gaseous state, with which the existence of a special solar atmosphere is incompatible. We must therefore assume that the whole solar mass is undergoing a continuous process of combustion, but which can only actually take place in the outermost layer of the body of the sun, where the solar gas is already so far cooled by expansion that chemical combinations can be formed. These 
then occur with formation of flame and enhanced temperature at the whole solar surface, whilst a flinging off, such as my brother assumes, can only be possible in the equatorial zone in a very limited degree. A general descent of the burnt mass cooled by radiation must follow the general ascent of the uppermost layers of the sun, in consequence of their combustion and heating beyond the diabatic temperature corresponding to their expansion. This takes place in innumerable descending streams, which give to the solar surface its scaly appearance, or in the mean solar latitudes also assumes the form of colossal descending vortices, which are darker than the rest of the solar surface, since the descending products of combustion indeed nearly recover, by their compression, the temperature, which they possessed at the beginning of the ascent, but are thereby also dissociated and correspondingly. cooled. For this reason and on account of the absence of flame these descending vortices appear as dark sunspots. Certainly this combustion-theory is still opposed by the circumstance that the existence of oxygen in the sun has hitherto been spectroscopically proved only at the bottom of the sun-spot funnel - but the greatest argument for it is, that the sun possesses a composition essentially the same as the earth, that therefore oxygen cannot be wanting.

I have tried to support this solar theory, which admits the origin and preservation of an electrical solar potential, by the proof that the latter would explain many hitherto unexplained terrestrial phenomena. With 
the colossal dimensions of the sun in comparison with those of the earth the sun's potential will call forth by electric distribution a terrestrial potential of nearly half the amount, if we assume, that the electricity, becoming free at the earth's surface, and similar to the solar electricity, is absorbed through radiation and neutralization by the electricity of the oppositely electrified matter, proceeding according to brother William's theory from the sun in the direction of the sun's equator. That this high electric tension is not observed at the earth's surface is a consequence of the size of the earth's radius. Now by the rotation of the earth the electricity bound to the earth's surface by the solar electricity is carried round the earth, and thus produces the effect of an electric current circling round it, which makes it magnetic. Just as the earth's magnetism, so also the terrestrial currents and polar lights find their explanation by the electrical solar potential, and similarly the reaction of phenomena in the sun, such as the occurrence of sun-spots and coronae, on terrestrial phenomena becomes explicable, if we conceive them intimately connected with changes of the sun's potential. Atmospheric and lightning electricity likewise find their explanation through the electrical solar potential.

Under the title "Contributions to the theory of electro-magnetism" I communicated two dissertations to the Berlin Academy in the years 1881 and 1884, in which the theory of magnetism was considerably extended, and parts of it, that had hitherto remained 
obscure, were cleared up. I arrived thereat by experiments with tubular electro-magnets, which gave the looked-for result that iron exerts no, or at any rate no appreciable, protection against magnetic action at a distance, and that the magnetic maximum of iron is independent of the direction of the magnetism. From this it follows that the magnetism called forth in iron by a magnetizing force is diminished by a simultaneous magnetization in another direction. The maximum magnetization occurring in ring-magnets even with feeble magnetizing power shows that the strengthening magnetizing effect, which magnetized iron molecules exert on their neighbours, considerably outweighs direct magnetization. This led me to the modification - already previously adopted by Stefan, as I afterwards found - of Weber's electro-magnetic theory, according to which the assumed elementary solenoids must be double solenoids, which as such move about freely in space, and are directed by a magnetizing force acting upon them, and then rotate round one another in a scissor-like fashion. If we suppose the whole universe to be filled with such double solenoids, which after the theory of Father Secchi and Edlund might be coneeived as ether-vortices, and that iron and the other magnetic bodies were distinguished from the nonmagnetic by the ether-vortices pre-existing in a unit of volume being more numerous in the former than the latter and in empty space, magnetic action at a distance might also be regarded according to Faraday's suggestion as an action proceeding from molecule to 
molecule or from space-element to space-element, and we should then be warranted in applying the laws for the molecular transference of heat, electricity, and electrostatic distribution to magnetism also.

This theory on its side compels us to assume, that magnetism, like the electric current and electric distribution, can only exist in closed circuits, in which the magnetic "moment" is inversely proportional to the resistance of the circuit. This consideration leads therefore to the introduction of the notions "resistance to magnetic distribution" and "magnetic conductivity" of space and magnetic bodies. According to this, only so much magnetism can be produced in an iron rod by an electric current circling round it as can be conveyed from one to the other pole, or absorbed by the space surrounding the iron rod. My experiments have confirmed this view, and their result shows that the magnetic conductivity of soft iron is approximately 500 times as great as that of non-magnetic matter and empty space.

Accordingly in the construction of electro-magnetic machines Ohm's law may be applied for ascertaining the most suitable dimensions, which will in many cases be useful to the electrical engineer. The notion first introduced by me, so far as I know, of magnetic conductivity has meanwhile often been employed and further developed in technical works - without any reference however to my priority.

The attempt described in my work on the sun's potential, to refer certain meteorological phenomena to 
disturbance of the indifferent equilibrium of the atmosphere, had convinced me, that in meteorology the requirements of mechanical equilibrium and the principle of the conservation of energy had not hitherto received proper attention. Recent meteorology, in its endeavour to deduce all the phenomena of atmospheric motion from its extensive material of observation, has too much lost sight of the causes of these movements. Scientists were generally content to be able to refer the aerial movements to the observed maxima and minima of the pressure of the air and its movements, and were satisfied with pointing to local influences of temperature and the earth's rotation in explanation of the causes of theses maxima and minima. In my paper "On the conservation of energy in the earth's aerial ocean" I have set up and defended the principle, that every motion of the air is exclusively to be ascribed to the unequal heating of the air by the sun's rays, and that the earth's rotation can produce no new motion of the air, but only change the direction of the motion produced by solar influence. One direct consequence of this principle is, that the sum of the vis viva stored up in the rotation of the aerial ocean on the earth's axis must unalterably be that, which this ocean would have, if no meridional motion of air were produced by solar influence, and the air everywhere had the rotatory velocity of that part of the surface, on which it rests. In consequence of the accelerating equatorial ascent of the overheated air, streaming to the equator in the trade-winds, a back 
current takes place in the upper regions of the atmosphere towards the poles, which however only in a small part can reach polar latitudes. The reason of this is that, owing to the narrowing of the upper and simultaneous expanding of the lower stratum in consequence of the decrease of the latitudinal circles on approaching the poles - a partial passage of the upper poleward moving current must continually take place into the lower current towards the equator. It is the inertia of the upper poleward travelling current, which carries back the air in the lower one to the equator. By this circulating current, continued for untold thousands of years, the air of the higher latitudes is intimately mixed with that of the lower ones, and the whole aerial ocean must therefore rotate with the mean easterly velocity of the earth's surface. The westerly course of the trade-winds is thereby explained, as well as the mean easterly direction of the aerial currents in the intermediate and polar latitudes. The maxima and minima are essentially concomitant phenomena of the alternation of temperature and of the velocity of motion of the upper equatorial aircurrent, and always depend on disturbances of the indifferent equilibrium of the overlying air-strata. When an aerial current, which has a higher or lower temperature than corresponds to its altitude in the adiabatic curve of temperature, breaks into the highest regions of the aerial ocean, the indifferent equilibrium of the whole aerial column is thereby disturbed, and neutralization must take place by ascending or descend- 
ing motion of air, according as the invading higher currents of air are too warm or too cold, thus also too light or too heavy for the indifferent equilibrium. This ascending or descending aerial motion must last until the indifferent equilibrium of the column of air is again restored, and the consequence then is, that the pressure of the atmosphere at the surface of the earth becomes as great as it would be, if the temperature of the whole column of air had changed as much as the equatorial current, causing the disturbance, deviates from the adiabatic temperature corresponding to its place and its height. As the consumption of heat during the active expansion of a quantity of air is independent of its commencing temperature, the air ascending at different places in the torrid zone must retain the differences of temperature, which it possessed before the rise. Hence it follows, that relatively warm and cold currents of air flow polewards with different velocity in the higher and highest strata of air, and thereby disturb the indifferent equilibrium of the atmosphere in its whole course. Slowly flowing, too cold currents will give off their surplus préssure to the lower aerial strata on which they are resting, without causing important disturbances, by compressing them, and thereby causing a rising barometric pressure in a calm atmosphere. Air-currents, which are relatively light, hot, and therefore strongly accelerated during their ascent, will on the other hand cause to undulate and carry with them the surface, insufficiently weighted by them, of the aerial strata over which 
they pass, and will thus, with a falling barometer, cause upward aerial movements, lasting until the indifferent equilibrium is again restored in the whole column of air. According to this, variations of temperature of 20 to $40^{\circ} \mathrm{F}$. in the highest strata of air suffice to produce the barometric fluctuations observed at the earth's surface, thus also the maxima and minima of the atmospheric pressure.

This theory has met with considerable approval, it however received the assent of the adherents of the prevailing views only in certain points, or is even entirely ignored by them. I have had occasion repeatedly to defend and further develop it. The papers relating thereto are entitled "On the question of air currents" (1887), "On the general system of terrestrial winds" (1890) and "On the question of the causes of atmospheric currents" (1891). I am convinced that my theory will gradually meet with universal acceptance, as it rests on a basis of facts. It is a necessary consequence of our system of instruction however, that new fundamental views, which contradict previous doctrines, should only slowly gain ascendency. They must first be embodied in text books, and that can only take place, when the new theory is worked out on all sides and the ruins of the hitherto dominant ones are cleared away. 




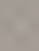


RETURN TO the circulation desk of any

University of California Library

or to the

NORTHERN REGIONAL LIBRARY FACILITY

Bldg. 400, Richmond Field Station

University of California

Richmond, CA 94804-4698

ALL BOOKS MAY BE RECALLED AFTER 7 DAYS

2-month loans may be renewed by calling

(415) 642-6753

1-year loans may be recharged by bringing books to NRLF

Renewals and recharges may be made 4 days prior to due date

DUE AS STAMPED BELOW

DR? 41991 


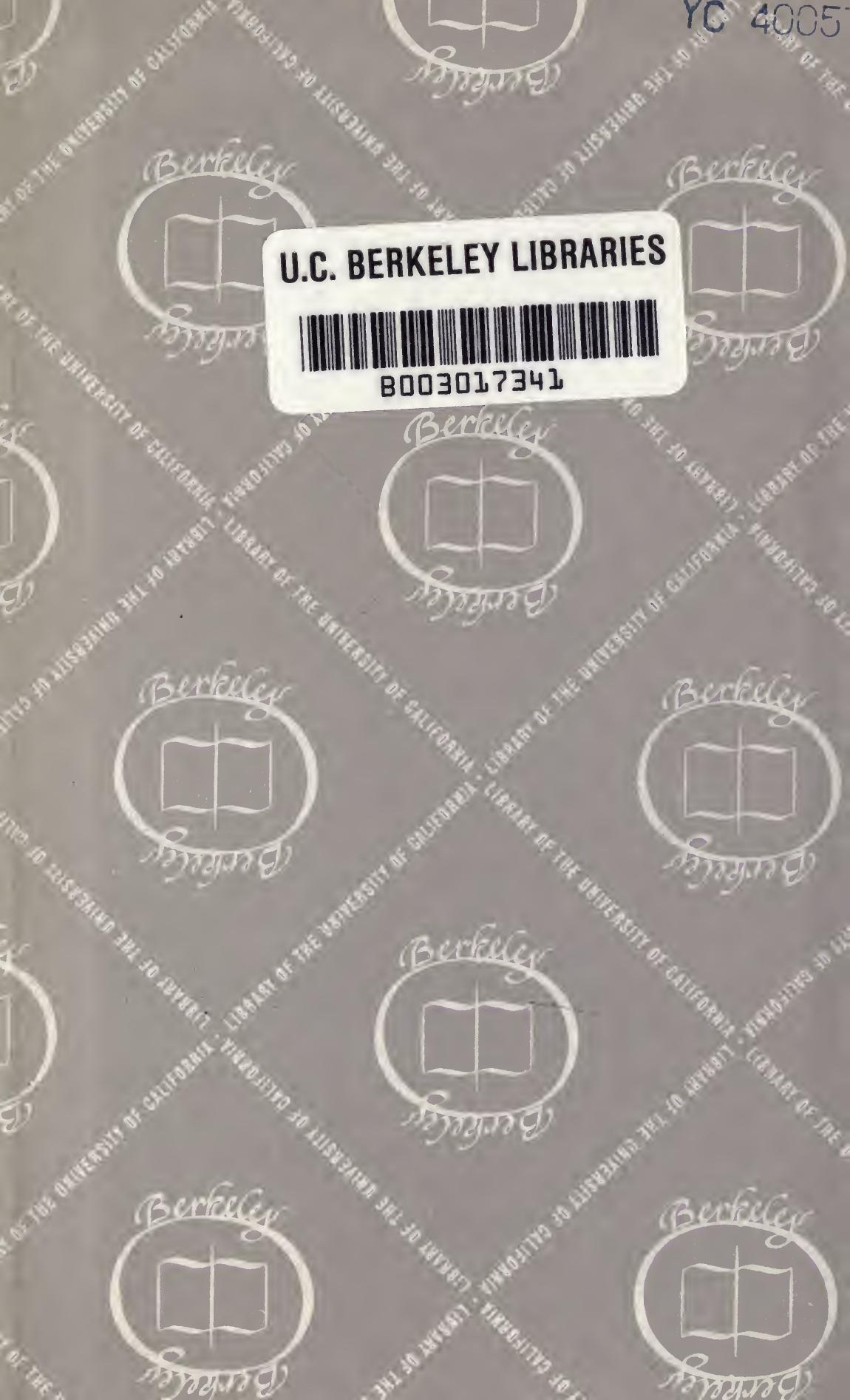


